ORP-56295

Revision 0

\title{
Final Report - Crystal Settling, Redox, and High Temperature Properties of ORP HLW and LAW Glasses, VSL-09R1510-1, Rev. 0, dated 6/18/09
}

Prepared for the U.S. Department of Energy

Assistant Secretary for Environmental Management

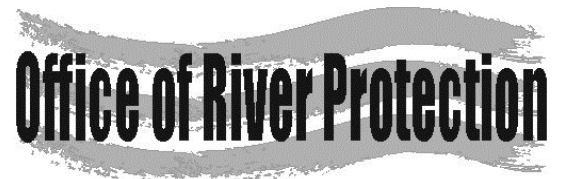

P.O. Box 450

Richland, Washington 99352 


\section{Final Report - Crystal Settling, Redox, and High Temperature Properties of ORP HLW and LAW Glasses, VSL-09R1510-1, Rev. 0 , dated 6/18/09}

\author{
A. A. Kruger \\ Department of Energy - Office of River Protection \\ C. Wang \\ The Catholic University of America \\ H. Gan \\ The Catholic University of America \\ I. L. Pegg \\ The Catholic University of America \\ M. Chaudhuri, \\ The Catholic University of America \\ W. Kot \\ The Catholic University of America \\ Z. Feng \\ The Catholic University of America
}

Date Published

June 2009

Prepared for the U.S. Department of Energy

Assistant Secretary for Environmental Management
C. Viragh

The Catholic University of America

D. A. McKeown

The Catholic University of America

I. Joseph

The Catholic University of America

I. S. Muller

The Catholic University of America

R. Cecil

The Catholic University of America

W. Zhao

The Catholic University of America

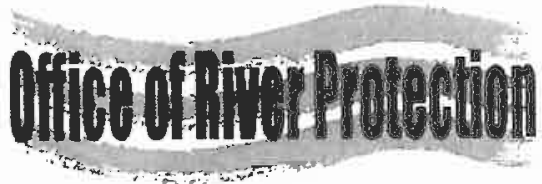

P.O. Box 450

Richland, Washington 99352

\section{APPROVED}

By Shauna Adams at 1:27 pm, Nov 13, 2013 
ORP-56295

Revision 0

TRADEMARK DISCLAIMER

Reference herein to any specific commercial product, process, or service by tradename, trademark, manufacturer, or otherwise, does not necessarily constitute or imply its endorsement, recommendation, or favoring by the United States Government or any agency thereof or its contractors or subcontractors.

This report has been reproduced from the best available copy.

Printed in the United States of America 
VSL-09R1510-1

\section{Final Report}

Crystal Settling, Redox, and High Temperature Properties of ORP HLW and LAW Glasses

prepared by

Hao Gan, Isabelle S. Muller, David A. McKeown, Malabika Chaudhuri, Zhijian Feng, Carol Viragh, Chuan Wang, Richard Cecil, Wei Zhao, Wing K. Kot, Innocent Joseph, and Ian L. Pegg

Vitreous State Laboratory

The Catholic University of America

Washington, DC 20064

$$
\text { for }
$$

EnergySolutions Federal EPC, Inc.

Laurel, MD 20707

and

Department of Energy

Office of River Protection

Richland, WA 99352

March 31, 2009

Rev. 0; 6/18/09 
The Catholic University of America Vitreous State Laboratory
Crystal Settling, Redox, and Properties of ORP HLW \& LAW Glasses

Final Report, VSL-09R15.10-1, Rev 0

Document Title: Crystal Settling, Redox, and High Temperature Properties of ORP HLW and LAW Glasses

\section{Document Number and Revision:}

Issue Date:

$$
\text { VSL-09R1510-1, Rev. } 0
$$

$6 / 18 / 09$

Performing Organization: Vitreous State Laboratory, The Catholic University of America

Test Plans: HLW Glass Formulation Development and Testing, VSL-08T1520-1, Rev. 0 LAW Glass Formulation Development and Testing, VSL-08T 1510-1, Rev. 0

This report describes the results of testing specified by the above Test Plans. The work was performed in compliance with the quality assuxance requirements specified in the Test Plans. Results required by the Test Plans are reported. The test results and this report have been reviewed for correctness, technical adequacy, completeness, and accuracy.

I.L. Pegg: VSL Program Director/Principal (pnve tigator

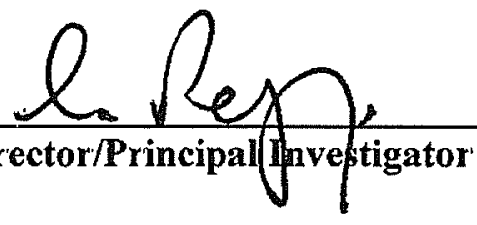

I. Joseph: Inmocent to seb b EnergySolutions Sub-Contraet Manager

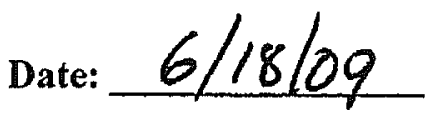

Date: $6 / 18 / 09$ 
The Catholic University of America

Vitreous State Laboratory
Crystal Settling, Redox, and Properties of ORP HLW \& LAW Glasses Final Report, VSL-09R1510-1, Rev. 0

\section{TABLE OF CONTENTS}

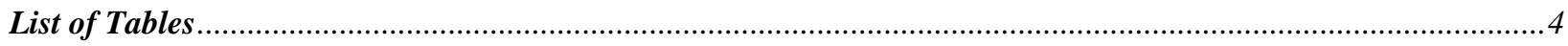

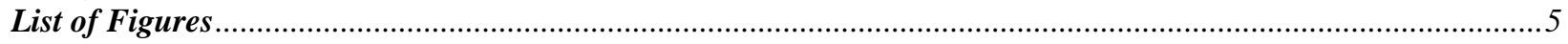

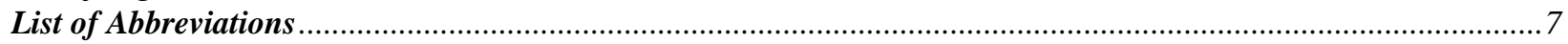

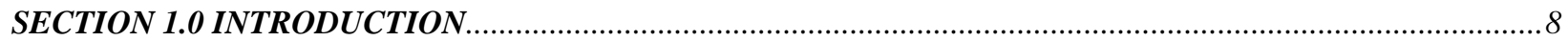

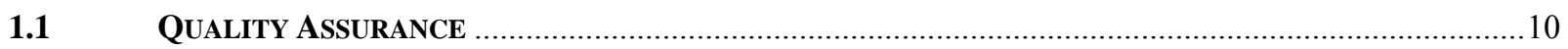

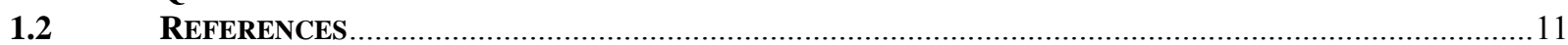

SECTION 2.0 CRYSTAL SETTLING AND GLASS MELT RHEOLOGY …...............................................14

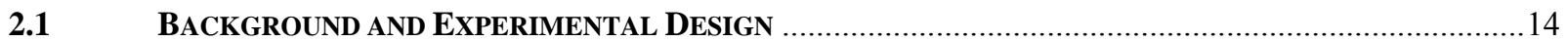

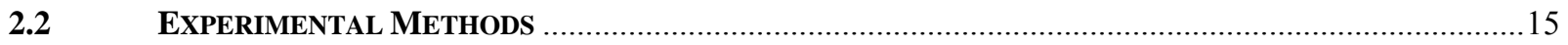

2.2.1 Crystal Settling Experiments .......................................................................................................15

2.2.2 Measurement of Glass Melt Rheology with Suspended Crystalline Phase............................................16

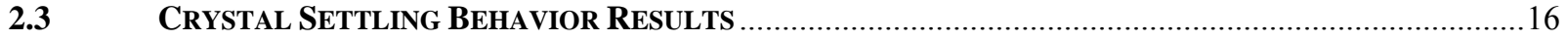

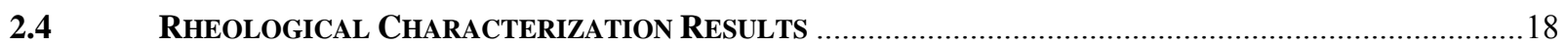

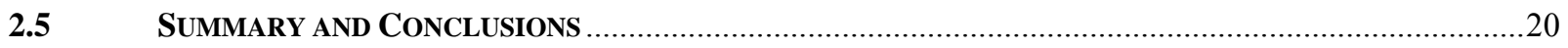

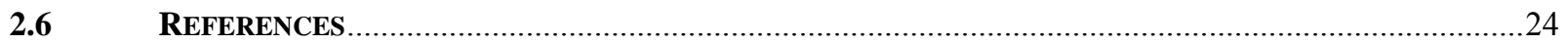

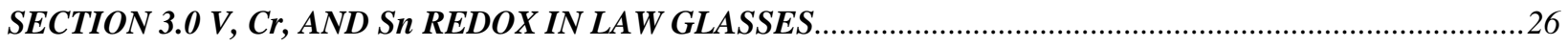

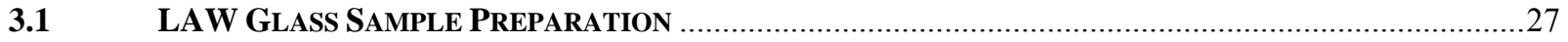

IRON REDOX EVALUATION BY MÖSSBAUER SPECTROSCOPY ……................................................

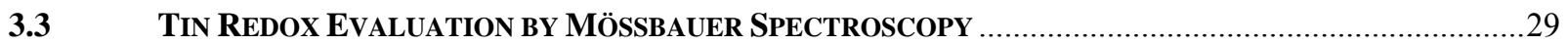

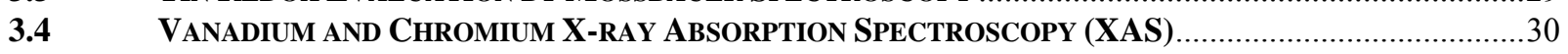

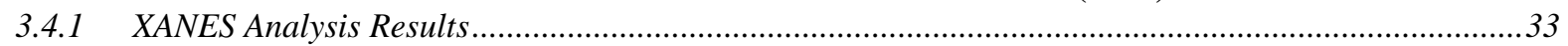

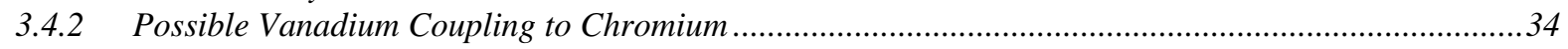

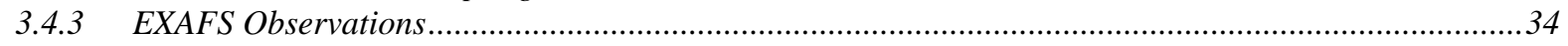

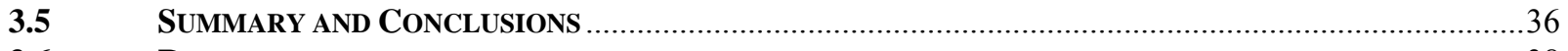

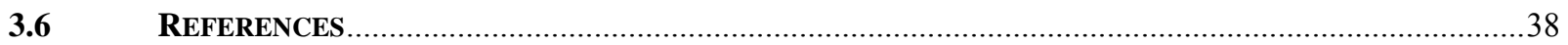

SECTION 4 HIGH TEMPERATURE PROPERTIES OF SELECTED HLW AND LAW GLASSES AND MELTS

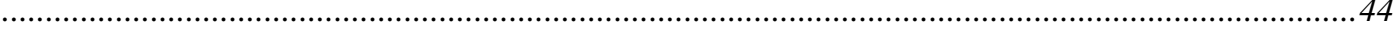

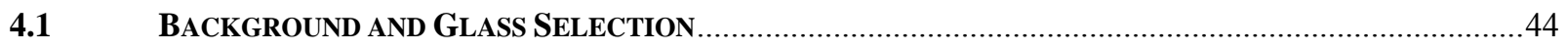

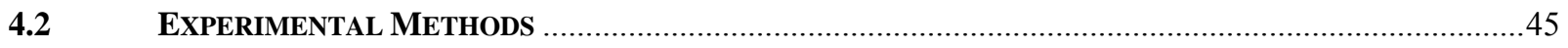

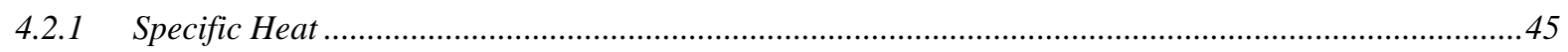

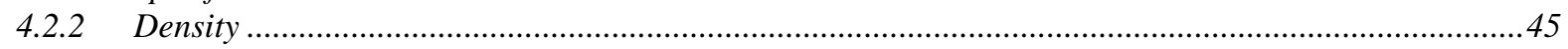

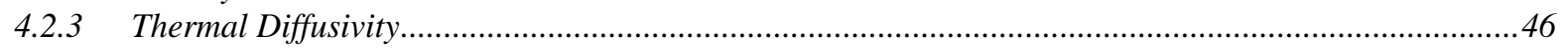

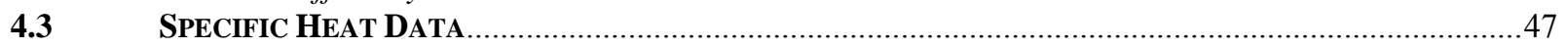

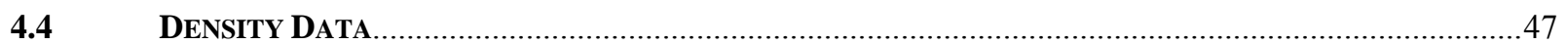

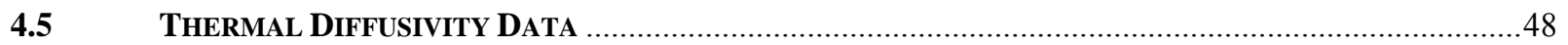

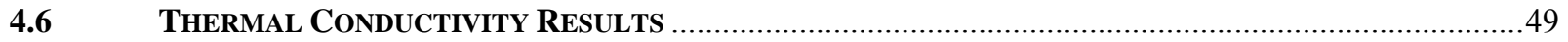

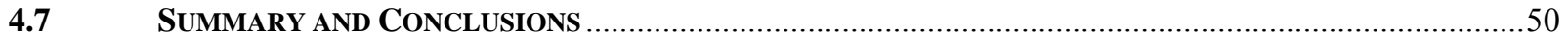

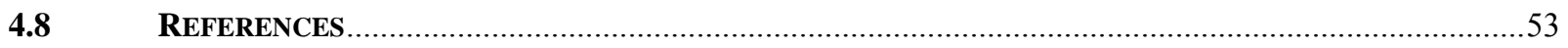

SECTION 5 IMPLICATIONS FOR WTP AND RECOMMENDATIONS FOR FUTURE WORK.....................55

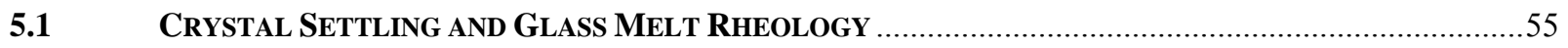

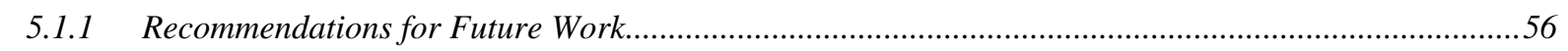

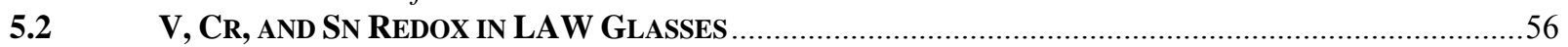

5.2.1 Recommendations for Future Work..............................................................................................5

5.3 High Temperature Properties OF SELECTEd HLW AND LAW GLASSES ANd MELTS ................57

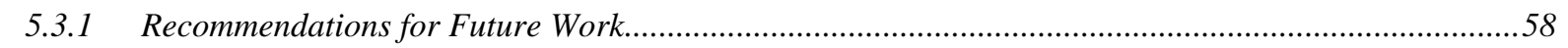

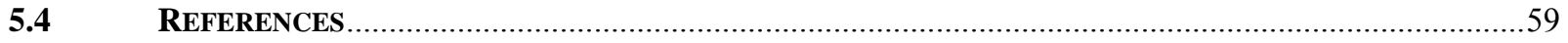


The Catholic University of America

Vitreous State Laboratory
Crystal Settling, Redox, and Properties of ORP HLW \& LAW Glasses

Final Report, VSL-09R1510-1, Rev. 0

\section{List of Tables}

Table 2.1

Table 2.2

Table 2.3

Table $2.4 \mathrm{a}$

Table $2.4 \mathrm{~b}$

Table 2.5a

Table 2.5b

Table 2.6a

Table 2.6b

Table 2.7

Table 2.8

Table 2.9

Table 2.10

Table 3.1

Table 3.2

Table 4.1

Table 4.2

Table 4.3

Table 4.4

Table 4.5
Target Composition of HLW Glasses for Crystal Settling and Rheology Characterization (wt\%).

Summary of Key Properties of the Three HLW Glasses/Melts [2-8].

Size Estimation of Major Crystalline Phase After Crystal Settling Experiments. Optical microscopy on thin sections from crystal settling experiments and SEM on samples from isothermal heat treatment (70hours).

Relative Torque vs. RPM (revolutions per minute) for HLW-E-ES-02 at a Given Test Temperature and Holding Time.

Viscosity vs. Shear Rate for HLW-E-ES-02 at a Given Test Temperature and Holding Time.

Relative Torque vs. RPM (revolutions per minute) for HLW-E-SP-05 at a Given Test Temperature and Holding Time. Viscosity vs. Shear Rate for HLW-E-SP-05 at a Given Test Temperature and Holding Time.

Relative Torque vs. RPM (revolutions per minute) for HLW-E-SP-06 at a Given Test Temperature and Holding Time.

Viscosity vs. Shear Rate for HLW-E-SP-06 at a Given Test Temperature and Holding Time.

Yield Stress Measurement and Analysis of the Relationship of Shear Stress vs. Shear Rate for HLW-E-ES-02.

Yield Stress Measurement and Analysis of the Relationship of Shear Stress vs. Shear Rate for HLW-E-SP-05.

Yield Stress Measurement and Analysis of the Relationship of Shear Stress vs. Shear Rate for HLW-E-SP-06.

Data Summary of Crystal Settling and Melt Rheology for Three HLW Glasses. Compositions of Glasses Used in Redox Studies.

Sample Identifications and Results of Redox Studies.

XRF Analyzed Compositions of Four Simulated Waste Glasses (wt\%).

Specific Heat of Four Simulated Waste Glasses/Melts During Heating $\left(5^{\circ} \mathrm{C} /\right.$ minute in air $)$.

Density of Four Simulated Waste Glass Melts $\left(\mathrm{g} / \mathrm{cm}^{3}\right)$.

Thermal Diffusivity of Four Simulated Waste Glass Melts.

Thermal Conductivity of Four Simulated Waste Glass Melts.
$\mathrm{T}-1$

$\mathrm{T}-2$

$\mathrm{T}-3$

$\mathrm{T}-4$

T-5

T-6

$\mathrm{T}-7$

T-8

T-9

T-10

T-11

T-12

T-13

T-14

T-15

T-16

T-17

T-19

T-20

T-21 
The Catholic University of America Vitreous State Laboratory
Crystal Settling, Redox, and Properties of ORP HLW \& LAW Glasses

Final Report, VSL-09R1510-1, Rev. 0

\section{List of Figures}

Figure 2.1

Figure 2.2

Figure 2.3

Figure 2.4

Figure 2.5a

Figure 2.5b

Figure $2.5 \mathrm{c}$

Figure 2.6a

Figure 2.6b

Figure 2.6c

Figure 2.7a

Figure 2.7b

Figure $2.7 \mathrm{c}$

Figure 2.8a

Figure $2.8 \mathrm{~b}$

Figure 2.8c

Figure 2.9a

Figure $2.9 \mathrm{~b}$

Figure 2.10a

Figure 2.10b

Figure 2.11a

Figure $2.11 \mathrm{~b}$

Figure 2.11c

Figure 2.11d

Figure 2.12a

Figure $2.12 b$

Figure 2.12c

Figure $2.12 \mathrm{~d}$

Figure 2.13a

Figure 2.13b

Figure 2.13c
Schematic drawing of double crucible set up for crystal settling experiment.

Scanned cross sections of HLW-E-ES-02 after crystal settling experiments at 950

(row 1), 1050 (row 2) and $1150^{\circ} \mathrm{C}$ (row 3) for $3.5,7,14$ and 28 hours, respectively.

Scanned cross sections of HLW-E-SP-05 after crystal settling experiments at 950

(row 1), 1050 (row 2) and $1150^{\circ} \mathrm{C}$ (row 3 ) for $3.5,7,14$ and 28 hours, respectively.

Scanned cross sections of HLW-E-SP-06 after crystal settling experiments at 950

(row 1 ), 1050 (row 2 ) and $1150^{\circ} \mathrm{C}$ (row 3 ) for $3.5,7,14$ and 28 hours, respectively.

Optical micro-images of eskolaite crystals in HLW-E-ES-02 after crystal settling

experiments at $950^{\circ} \mathrm{C}$ for $3.5,7,14$ and 28 hours (top to bottom).

Optical micro-images of eskolaite crystals in HLW-E-ES-02 after crystal settling

experiments at $1050^{\circ} \mathrm{C}$ for $3.5,7,14$ and 28 hours (top to bottom).

Optical micro-images of eskolaite crystals in HLW-E-ES-02 after crystal settling experiments at $1150^{\circ} \mathrm{C}$ for $3.5,7,14$ and 28 hours (top to bottom).

Optical micro-images of crystal particles in HLW-E-SP-05 after crystal settling experiments at $950^{\circ} \mathrm{C}$ for $3.5,7,14$ and 28 hours (top to bottom).

Optical micro-images of crystal particles in HLW-E-SP-05 after crystal settling experiments at $1050^{\circ} \mathrm{C}$ for $3.5,7,14$ and 28 hours (top to bottom).

Optical micro-images of crystal particles in HLW-E-SP-05 after crystal settling experiments at $1150^{\circ} \mathrm{C}$ for $3.5,7,14$ and 28 hours (top to bottom).

Optical micro-images of crystal particles in HLW-E-SP-06 after crystal settling experiments at $950^{\circ} \mathrm{C}$ for $3.5,7,14$ and 28 hours (top to bottom).

Optical micro-images of crystal particles in HLW-E-SP-06 after crystal settling experiments at $1050^{\circ} \mathrm{C}$ for $3.5,7,14$ and 28 hours (top to bottom).

Optical micro-images of crystal particles in HLW-E-SP-06 after crystal settling

experiments at $1150^{\circ} \mathrm{C}$ for $3.5,7,14$ and 28 hours (top to bottom).

F-1

F-2

F-3

F-4

F-5

F-6

F-7

F-8

F-9

F-10

F-11

F-12

F-13

Crystal content distribution in the test crucible for HLW-E-ES-02 settling experiments at $950^{\circ} \mathrm{C}$ for $3.5,7,14$ and 28 hours.

F-14

F-15

experiments at $1050^{\circ} \mathrm{C}$ for $3.5,7,14$ and 28 hours.

Crystal content distribution in the test crucible for HLW-E-ES-02 settling

experiments at $1150^{\circ} \mathrm{C}$ for $3.5,7,14$ and 28 hours.

F-16

Crystal content distribution in the test crucible for HLW-E-SP-05 settling

experiments $950^{\circ} \mathrm{C}$ for $3.5,7,14$ and 28 hours.

F-17

Crystal content distribution in the test crucible for HLW-E-SP-05 settling experiments at $1050^{\circ} \mathrm{C}$ for $3.5,7,14$ and 28 hours.

F-18

Crystal content distribution in the test crucible for HLW-E-SP-06 settling experiments at $950^{\circ} \mathrm{C}$ for $3.5,7,14$ and 28 hours.

Crystal content distribution in the test crucible for HLW-E-SP-06 settling experiments at $1050^{\circ} \mathrm{C}$ for $3.5,7,14$ and 28 hours.

Viscosity vs. shear rate for HLW-E-ES-02 at $1265^{\circ} \mathrm{C}$.

Viscosity vs. shear rate for HLW-E-ES-02 at $1164^{\circ} \mathrm{C}$.

Viscosity vs. shear rate for HLW-E-ES-02 at $1062^{\circ} \mathrm{C}$.

Viscosity vs. shear rate for HLW-E-ES-02 at $961^{\circ} \mathrm{C}$.

Viscosity vs. shear rate for HLW-E-SP-05 at $1263^{\circ} \mathrm{C}$.

Viscosity vs. shear rate for HLW-E-SP-05 at $1162^{\circ} \mathrm{C}$.

Viscosity vs. shear rate for HLW-E-SP-05 at $1060^{\circ} \mathrm{C}$.

Viscosity vs. shear rate for HLW-E-SP-05 at $960^{\circ} \mathrm{C}$.

Viscosity vs. shear rate for HLW-E-SP-06 at $1161^{\circ} \mathrm{C}$.

Viscosity vs. shear rate for HLW-E-SP-06 at $1062^{\circ} \mathrm{C}$.

Viscosity vs. shear rate for HLW-E-SP-06 at $963^{\circ} \mathrm{C}$.

\section{F-19}

F-20

F-21

F-22

F-23

F-24

F-25

F-26

F-27

F-28

F-29

F-30

F-31 
The Catholic University of America Vitreous State Laboratory
Crystal Settling, Redox, and Properties of ORP HLW \& LAW Glasses

Final Report, VSL-09R1510-1, Rev. 0
Figure 2.14a

Figure $2.14 \mathrm{~b}$

Figure $2.14 \mathrm{c}$

Figure $2.14 \mathrm{~d}$

Figure 2.15a

Figure 2.15b

Figure $2.15 \mathrm{c}$

Figure $2.15 \mathrm{~d}$

Figure 2.16a

Figure 2.16b

Figure 2.16c

Figure 3.1

Figure 3.2

Figure 3.3

Figure 3.4

Figure 3.5

Figure 3.6

Figure 3.7

Figure 3.8

Figure 4.1

Figure 4.2

Figure 4.3

Figure 4.4

Figure 4.5

Figure 4.6

Figure 4.7

Figure 4.8
Viscosity vs. dwell time for HLW-E-ES-02 at $1265^{\circ} \mathrm{C}$.

Viscosity vs. dwell time for HLW-E-ES-02 $1164^{\circ} \mathrm{C}$.

Viscosity vs. dwell time for HLW-E-ES-02 at $1062^{\circ} \mathrm{C}$.

Viscosity vs. dwell time for HLW-E-ES-02 at $961^{\circ} \mathrm{C}$.

Viscosity vs. dwell time for HLW-E-SP-05 at $1263^{\circ} \mathrm{C}$.

Viscosity vs. dwell time for HLW-E-SP-05 at $1162^{\circ} \mathrm{C}$.

Viscosity vs. dwell time for HLW-E-SP-05 $1060^{\circ} \mathrm{C}$.

Viscosity vs. dwell time for HLW-E-SP-05 at $960^{\circ} \mathrm{C}$.

Viscosity vs. dwell time for HLW-E-SP-06 at $1161^{\circ} \mathrm{C}$.

Viscosity vs. dwell time for HLW-E-SP-06 at $1062^{\circ} \mathrm{C}$.

Viscosity vs. dwell time for HLW-E-SP-06 at $963^{\circ} \mathrm{C}$.

Iron Mössbauer spectra of glasses R10G155BRE6 (top) and DWVG123BRE2 (bottom).

$\mathrm{Cr}, \mathrm{Fe}, \mathrm{Sn}$, and V redox couples from Schreiber et al. 3-[34].

Tin Mössbauer spectrum of glass R10G155BRE8.

$\mathrm{V}$ and $\mathrm{Cr}$ reduction for the $\mathrm{Z} 10-\mathrm{G}-60 \mathrm{C}$ glass versus $\mathrm{CO} / \mathrm{CO}_{2}$ bubbling time.

$\mathrm{V}$ and $\mathrm{Cr}$ reduction for the $\mathrm{Q} 10-\mathrm{G}-136 \mathrm{D}$ glasses versus $\mathrm{CO} / \mathrm{CO}_{2}$ bubbling time.

$\mathrm{V}$ and $\mathrm{Cr}$ reduction for the DWV-G-123B glasses versus $\mathrm{CO} / \mathrm{CO}_{2}$ bubbling time.

$\mathrm{V}$ partial RDFs for the $\mathrm{V}^{5+}, \mathrm{V}^{4+}$, and $\mathrm{V}^{3+}$ standards and the parent and more reduced DWV-G-123B glasses.

Cr partial RDFs for the $\mathrm{Cr}^{6+}$ and $\mathrm{Cr}^{3+}$ standards and three of the more $\mathrm{Cr}$-rich glasses studied.

Specific heat of four simulated waste glasses/melts during heating $\left(5^{\circ} \mathrm{C} /\right.$ minute in air).

Specific heat of four simulated waste glasses/melts during heating and cooling

near the glass transition $\left(5^{\circ} \mathrm{C} /\right.$ minute $)$.

Density of four simulated waste glass melts.

Density of four simulated waste glass melts and comparison to density data for

three simulated waste glass melts from regression equations provided by Pye et al. [4-8]. F-54

Thermal diffusivity of four simulated waste glass melts.

Thermal diffusivity of four simulated waste glass melts in comparison to data

for three simulated waste glass melts by Derby et al. [4-20].

Thermal conductivity of four simulated waste glass melts calculated from the average

data for specific heat, density, and thermal diffusivity.

Thermal conductivity of four simulated waste melts in comparison to data for

$\mathrm{SiO}_{2}$ glass.
F-32

F-33

F-34

F-35

F-36

F-37

F-38

F-39

F-40

F-41

F-42

F-43

F-44

F-45

F-46

F-47

F-48

F-49

F-50

F-51

F-52

F-53

F-55

F-56

F-57

F-58 
The Catholic University of America Vitreous State Laboratory
Crystal Settling, Redox, and Properties of ORP HLW \& LAW Glasses

Final Report, VSL-09R1510-1, Rev. 0

\section{List of Abbreviations}

$\begin{array}{ll}\text { ASTM } & \text { American Society for Testing and Materials } \\ \text { CCN } & \text { Correspondence Control Number } \\ \text { CUA } & \text { The Catholic University of America } \\ \text { DOE } & \text { Department of Energy } \\ \text { DSC } & \text { Differential Scanning Calorimetry } \\ \text { DS } & \text { Energy Dispersive X-Ray Spectroscopy } \\ \text { DWPF } & \text { Defense Waste Processing Facility } \\ \text { EXAFS } & \text { Extended X-ray Absorption Fine Structure } \\ \text { HLW } & \text { High Level Waste } \\ \text { ILAW } & \text { Immobilized Low-Activity Waste } \\ \text { LAW } & \text { Low-Activity Waste } \\ \text { NIST } & \text { National Institute of Standards and Technology } \\ \text { NQA } & \text { Nuclear Quality Assurance } \\ \text { PCT } & \text { Product Consistency Test } \\ \text { QA } & \text { Quality Assurance } \\ \text { RDF } & \text { radial distribution function } \\ \text { RPP } & \text { River Protection Project } \\ \text { Redox } & \text { Reduction-Oxidation } \\ \text { SEM } & \text { Scanning Electron Microscopy } \\ \text { VHT } & \text { Vapor Hydration Test } \\ \text { VSL } & \text { Vitreous State Laboratory } \\ \text { WTP } & \text { Hanford Tank Waste Treatment and Immobilization Plant } \\ \text { WVDP } & \text { West Valley Demonstration Project } \\ \text { XANES } & \text { X-ray Absorption Near Edge Structure } \\ \text { XRD } & \text { X-ray Diffraction } \\ \text { XRF } & \text { X-ray Fluorescence Spectroscopy }\end{array}$


The Catholic University of America Vitreous State Laboratory
Crystal Settling, Redox, and Properties of ORP HLW \& LAW Glasses

Final Report, VSL-09R1510-1, Rev. 0

\section{SECTION 1.0 INTRODUCTION}

The radioactive tank waste treatment programs at the U. S. Department of Energy (DOE) have featured joule heated ceramic melter technology for the vitrification of high level waste (HLW). The Hanford Tank Waste Treatment and Immobilization Plant (WTP) employs this same basic technology not only for the vitrification of HLW streams but also for the vitrification of Low Activity Waste (LAW) streams. Because of the much greater throughput rates required of the WTP as compared to the vitrification facilities at the West Valley Demonstration Project (WVDP) or the Defense Waste Processing Facility (DWPF), the WTP employs advanced joule heated melters with forced mixing of the glass pool (bubblers) to improve heat and mass transport and increase melting rates. However, for both HLW and LAW treatment, the ability to increase waste loadings offers the potential to significantly reduce the amount of glass that must be produced and disposed and, therefore, the overall project costs. This report presents the results from a study to investigate several glass property issues related to WTP HLW and LAW vitrification: crystal formation and settling in selected HLW glasses; redox behavior of vanadium and chromium in selected LAW glasses; and key high temperature thermal properties of representative HLW and LAW glasses. The work was conducted according to Test Plans that were prepared for the HLW [1-1] and LAW scope [1-2], respectively. The results from melter testing described in these Test Plans are reported separately [1$3,1-4]$.

Enhanced glass formulations are being explored to increase waste loadings in WTP HLW glasses. The waste loading for high-level nuclear waste streams at the WTP is typically limited by crystal formation because of the relatively high concentrations of elements such as $\mathrm{Fe}, \mathrm{Cr}, \mathrm{Ni}, \mathrm{Zr}, \mathrm{Al}$, $\mathrm{Bi}, \mathrm{P}$, etc., in the waste and their tendency to form crystalline phases. While the presence of crystalline phases seldom affects the quality of the glass product, it can present a significant processing concern since such phases can settle and accumulate in the melter, adversely affecting melter operations and ultimately reducing the life of the melter. For this reason, HLW glasses (e.g., DWPF and WVDP) have traditionally been designed to have a liquidus temperature that is lower than the nominal processing temperature by some target value. The liquidus temperature restriction is met by reducing waste loadings in glass (together with appropriately designed glass formulations), thus mitigating the risk of crystal formation. However, since the basic practical issue is crystal settling and accumulation, depending upon the crystal size and density, non-zero amounts of near-liquidus phases can often be maintained in suspension and, therefore, tolerated in bubbled melters. These considerations have led EnergySolutions/VSL to develop and implement an "operational liquidus" constraint in which a non-zero fraction of crystals is tolerated at a given temperature. Glasses designed for DuraMelter vitrification systems have employed a limit of $<1 \mathrm{vol} \%$ crystals at a reference temperature (typically $950^{\circ} \mathrm{C}$ ) below the operating temperature. Based on extensive testing and demonstration, this constraint has now been formally adopted for use at the Hanford WTP in place of the traditional, more conservative, liquidus-temperature constraint. Further increasing the amount of crystals allowable in the glass would further increase waste loadings and therefore further reduce waste treatment costs. 
The Catholic University of America Vitreous State Laboratory
Crystal Settling, Redox, and Properties of ORP HLW \& LAW Glasses

Final Report, VSL-09R1510-1, Rev. 0

One part of this work thus addresses some of the possible detrimental effects due to considerably higher crystal content in waste glass melts and, in particular, the impact of high crystal contents on the flow property of the glass melt and the settling rate of representative crystalline phases in an environment similar to that of an idling glass melter. Factors that could influence the settling rate include the size, shape, and density of the crystalline phase, the apparent viscosity of the host melt, and the yield stress if the fluid is non-Newtonian. In spite of its importance, few data are available on the rheological behavior of waste glass melts with suspended crystalline phases, or for the settling behavior of crystalline phases in a controlled environment resembling that of an idling glass melter. In this work, three HLW glasses over-saturated with spinel or eskolaite phase were characterized for their settling and flow behavior at temperatures typical of an operating waste glass melter.

The waste loading in WTP LAW glasses is limited primarily by sulfate incorporation during melter processing and/or the leaching resistance of glass product due to the high sodium content. Previous work at VSL has demonstrated the benefits of vanadium additions in managing sulfate incorporation [1-5 - 1-16] and tin additions in managing vapor phase hydration test response (VHT) to maintain acceptable glass durability at high sodium contents [1-13, 1-17-1-20 ]. In addition, in some cases, iron has been removed entirely from the glass forming chemicals. However, the presence of iron in LAW glass systems can provide a redox buffer for the often fluctuating redox environment during vitrification, thereby reducing release of oxygen and the associated tendency for foaming. It is, therefore, of interest to investigate the behavior of the $\mathrm{V}^{5+} / \mathrm{V}^{4+}$ redox couple in typical WTP LAW glasses in under to understand the similarities and differences compared to that of the $\mathrm{Fe}^{3+} / \mathrm{Fe}^{2+}$ redox couple. Characterization of vanadium redox shifts in representative WTP LAW glasses is, therefore, the second focal point of this work. In addition, two other elements, tin and chromium, have been investigated with respect to their predominant valence status and redox behavior in these glasses. The possibility of interactions and coupled reactions between these redox systems was also investigated.

The third part of this work focused on key high temperature thermal properties of representative WTP HLW and LAW glasses over a wide range of temperatures, from the melter operating temperature to the glass transition. The properties determined are the density, specific heat, thermal diffusivity, and thermal conductivity. One of the primary motivations for collection of these data was to support WTP heat load modeling calculations, particularly for WTP canister filling and cooling. Despite the importance of these properties, there have been no previous measurements of them for WTP HLW or LAW glasses.

The results from each of these three parts of this work are presented and discussed in the following three sections. The HLW crystal settling and rheology work is presented in Section 2; the LAW redox work is presented in Section 3; and the HLW and LAW high temperature property work is presented in Section 4. 
The Catholic University of America Vitreous State Laboratory
Crystal Settling, Redox, and Properties of ORP HLW \& LAW Glasses

Final Report, VSL-09R1510-1, Rev. 0

\subsection{Quality Assurance}

This work was conducted under a quality assurance program compliant with 10 CFR 830 Subpart A, NQA-1 (2000), and DOE Order 414.1C. This program is supplemented by a Quality Assurance Project Plan for ORP work that is conducted at VSL [1-21]. Test and procedure requirements by which the testing activities are planned and controlled are defined in this plan. The program is supported by VSL standard operating procedures that were used for this work [1-22]. Exceptions are the X-ray absorption spectroscopy measurements and the tin Mössbauer spectroscopy measurements, which were performed at outside facilities and are of research quality. The requirements of DOE/RW-0333P are not applicable to this work. 
The Catholic University of America

Vitreous State Laboratory
Crystal Settling, Redox, and Properties of ORP HLW \& LAW Glasses Final Report, VSL-09R1510-1, Rev. 0

\subsection{References}

[1-1] "HLW Glass Formulation Development and Testing," K.S. Matlack, W.K. Kot, H. Gan, I. Joseph, and I.L. Pegg, VSL Test Plan, VSL-08T1520-1, Rev. 0, Vitreous State Laboratory, The Catholic University of America, Washington, DC, 6/18/08.

[1-2] "LAW Glass Formulation Development and Testing," K.S. Matlack, I.S. Muller, I. Joseph, and I.L. Pegg, VSL Test Plan, VSL-08T1510-1, Rev. 0, Vitreous State Laboratory, The Catholic University of America, Washington, DC, 6/6/08.

[1-3] "Effects of High Spinel and Chromium Oxide Crystal Contents on Simulated HLW Vitrification in DM100 Melter Tests," K.S. Matlack, W.K. Kot, W. Gong, W. Lutze, I.L. Pegg and I. Joseph, VSL Final Report, VSL-09R1520-1, Rev. 0, Vitreous State Laboratory, The Catholic University of America, Washington, DC, 6/19/09.

[1-4] "LAW Glass Formulation Development and Testing," K.S. Matlack, I.S. Muller, I. Joseph, and I.L. Pegg, VSL Final Report, VSL-09R1510-2, Rev. 0, Vitreous State Laboratory, The Catholic University of America, Washington, DC, 6/12/09.

[1-5] "Summary of Preliminary Results on Enhanced Sulfate Incorporation During Vitrification of LAW Feeds", I.L. Pegg, H. Gan, I.S. Muller, D.A. McKeown, and K.S. Matlack, VSL00R3630-1, Vitreous State Laboratory, The Catholic University of America, Washington, DC, $4 / 5 / 00$.

[1-6] “Sulfur Incorporation in Waste Glass Melts of Various Compositions," W.K. Kot, H. Gan, and I.L. Pegg, Ceramic Transactions, Vol. 107, pp. 441, Eds. G.T. Chandler and X. Feng, American Ceramic Society, 2000.

[1-7] "Melter Tests with LAW Envelope B Simulants to Support Enhanced Sulfate Incorporation," K.S. Matlack, S.P. Morgan, and I.L. Pegg, Final Report, VSL-00R3501-1, Rev. 0, Vitreous State Laboratory, The Catholic University of America, Washington, D.C., 11/27/00.

[1-8] "Melter Tests with LAW Envelope A and C Simulants to Support Enhanced Sulfate Incorporation," K.S. Matlack, S.P. Morgan, and I.L. Pegg, Final Report, VSL-01R3501-2, Rev. 0, Vitreous State Laboratory, The Catholic University of America, Washington, D.C., $1 / 26 / 01$.

[1-9] “Glass Formulation And Testing With RPP-WTP LAW Simulants," I.S. Muller, A.C. Buechele, and I.L. Pegg, Final Report, VSL-01R3560-2, Vitreous State Laboratory, The Catholic University of America, Washington, DC, 2/23/01. 
The Catholic University of America Vitreous State Laboratory
Crystal Settling, Redox, and Properties of ORP HLW \& LAW Glasses Final Report, VSL-09R1510-1, Rev. 0

[1-10] "X-ray Absorption Studies of Vanadium Valence and Local Environment in Borosilicate Waste Glasses Using Vanadium Sulfide, Silicate, and Oxide Standards", D.A. McKeown, I.S. Muller, K.S. Matlack, and I.L. Pegg, , J. Non-Crystalline Solids, 298, 160-175 (2002).

[1-11] "X-ray Absorption Studies of Vanadium Valence and Local Environment in Borosilicate Waste Glasses," D.A. McKeown, I.S. Muller, K.S. Matlack, and I.L. Pegg, Scientific Basis for Nuclear Waste Management XXV, Materials Research Society, 713, 547-554, (2002).

[1-12] "Glass Formulation Testing to Increase Sulfate Incorporation," K. S. Matlack, M. Chaudhuri, H. Gan, I.S. Muller, W. Gong, and I.L. Pegg, Final Report, VSL-04R4960-1, Rev. 0, Vitreous State Laboratory, The Catholic University of America, Washington, DC, 2/28/05.

[1-13] "Glass Formulation Testing to Increase Sulfate Volatilization from Melter," K.S. Matlack, W. Gong, and I.L. Pegg, Final Report, VSL-04R4970-1, Rev. 0, Vitreous State Laboratory, The Catholic University of America, Washington, DC, 2/24/05.

[1-14] "LAW Envelope C Glass Formulation Testing to Increase Waste Loading," K.S. Matlack, W. Gong, I.S. Muller, I. Joseph, and I.L. Pegg, Final Report, VSL-05R5900-1, Rev. 0, Vitreous State Laboratory, The Catholic University of America, Washington, DC, 1/27/06.

[1-15] "LAW Envelope A and B Glass Formulation Testing to Increase Waste Loading," K.S. Matlack, H. Gan, I.S. Muller, I. Joseph, and I.L. Pegg, Final Report, VSL-06R6900-1, Rev. 0, Vitreous State Laboratory, The Catholic University of America, Washington, DC, 3/23/06.

[1-16] "Enhanced LAW Glass Formulation Testing," K.S. Matlack, I. Joseph, W. Gong, I.S. Muller, and I.L. Pegg, Final Report, VSL-07R1130-1, Rev. 0, Vitreous State Laboratory, The Catholic University of America, Washington, DC, 10/05/07.

[1-17] "Composition Effects on the Vapor Hydration of Waste Glasses," A.C. Buechele, F. Lofaj, I.S. Muller, C.T. Mooers, and I.L. Pegg, Ceramic Transactions, Vol. 155, p. 289, (2004).

[1-18] "Vapor Hydration Testing of Tin-Containing Glasses", A.C. Buechele, C.T. Mooers, I.S. Muller, H. Gan and I.L. Pegg, 106th Annual Meeting of The American Ceramic Society, April 4, Indianapolis, 2004.

[1-19] "Tin as an Additive to Improve the VHT performance of High-Alkali Waste Glasses", A.C. Buechele, C.T. Mooers, I.S. Muller, H. Gan, and I.L. Pegg, Materials Science and Technologies 2006, Cincinnati, OH, Oct. 15-18, 2006

[1-20] "Tin Valence and Local Environments in Silicate Glasses as Determined from X-ray Absorption Spectroscopy", D.A. McKeown, A.C. Buechele, H.Gan, and I.L. Pegg, J. NonCrystalline Solids, 354, 3142 (2008). 
The Catholic University of America Vitreous State Laboratory
Crystal Settling, Redox, and Properties of ORP HLW \& LAW Glasses Final Report, VSL-09R1510-1, Rev. 0

[1-21] "Quality Assurance Project Plan for ORP RPP-WTP Support Activities Conducted by VSL," Vitreous State Laboratory, VSL-QAPP-ORP, Rev. 0, Vitreous State Laboratory, The Catholic University of America, Washington, DC, 6/24/08.

[1-22] "Master List of Controlled VSL Manuals and Standard Operating Procedures in Use," QAMLCP, Rev. 36, Vitreous State Laboratory, The Catholic University of America, Washington, DC, 2/19/09. 
The Catholic University of America Vitreous State Laboratory
Crystal Settling, Redox, and Properties of ORP HLW \& LAW Glasses

Final Report, VSL-09R1510-1, Rev. 0

\section{SECTION 2.0 \\ CRYSTAL SETTLING AND GLASS MELT RHEOLOGY}

\subsection{Background and Experimental Design}

The work described in this section is motivated by the potential for substantial economic benefits that can be realized if glass melters can tolerate a modest amount of crystals at the nominal operating temperature of $1150^{\circ} \mathrm{C}$. This is because crystal formation is typically the most restrictive waste loading constraint for HLW compositions. Glasses designed for DuraMelter vitrification systems have employed a limit of $<1 \mathrm{vol} \%$ crystals at a reference temperature (typically $950^{\circ} \mathrm{C}$ ) below the operating temperature [2-1]. This is already a less conservative approach than the traditional liquidus temperature requirement (essentially, a 0 vol\% limit). For HLW glass systems, the most common crystalline phases observed after heat treatment at $950^{\circ} \mathrm{C}$ are spinel or oxides rich in $\mathrm{Fe}$, and $\mathrm{Cr}$. The presence of spinel type crystalline phases seldom affects the quality of the glass product, but it can present a significant processing concern since such phases can settle and accumulate in the melter, adversely affecting melter operations and ultimately reducing the life of the melter. Therefore, the waste loading in a glass can be increased if glasses with modest levels of crystals at $1150^{\circ} \mathrm{C}$ can be demonstrated to be processable in a typical waste glass melter. The important underlying phenomena to address are the flow properties of a glass melt with suspended crystals and the settling behavior of the crystals that nucleate, grow, and accumulate during and after the conversion from melter slurry feed to glass melt.

Once formed, spinels ( and $\mathrm{Cr}_{2} \mathrm{O}_{3}$ ) crystals tend to settle to the bottom of the glass pool due to their considerably higher density as compared to the glass melt (roughly twice as high). The settling velocity $v$ of a spherical particle of radius $r$ and density $\rho_{\mathrm{s}}$ is expressed by Stoke's Law:

$$
v=k\left(\rho_{\mathrm{s}}-\rho_{1}\right) g r^{2} / \eta,
$$

where, $\rho_{1}$ is the fluid density, $\eta$ is the fluid viscosity, $k$ is a constant, and $g$ is the acceleration due to gravity. However, the situation becomes more complex as the concentration of crystals in the fluid is not negligible. For instance, Sparks et al. [2-2] have pointed out that a melt containing a few vol\% of crystals may behave rheologically like a Bingham plastic characterized by a constant yield stress that would likely control the particle settling behavior in the early stages. In such a situation, a crystal would need to grow large enough to overcome the yield stress in order for settling to occur. Furthermore, the yield stress of a fluid system with suspended crystals could be a function of its crystal content; therefore, the yield stress and the settling behavior will evolve with the changes in vol\% of crystalline phase, crystal size, and agglomeration in the host glass melt.

In spite of their importance in potentially enhancing waste loadings, relevant data on crystal settling and rheology available from the published literature are relatively scarce and system dependent [2-3 - 2-7]. Consequently, one of the objectives of this task was the collection of pertinent data under typical melter operating conditions for selected representative WTP HLW glasses. Specifically, this work has been designed to address the following: 
The Catholic University of America Vitreous State Laboratory
Crystal Settling, Redox, and Properties of ORP HLW \& LAW Glasses

Final Report, VSL-09R1510-1, Rev. 0

- Collection of data on particles of spinel or $\mathrm{Cr}_{2} \mathrm{O}_{3}$ that grow and redistribute within three representative HLW glass melts.

- Collection of data on the rheological behavior of glass melts containing suspended particles.

- Analysis of experimentally collected data and identification of key parameters that would impact the settling behavior of crystal particles in HLW glass melts.

Three HLW glasses were formulated specifically for crystal settling, melt rheology characterization, and subsequent melter testing [2-8]. The compositions of these glasses are listed in Table 2.1. To ensure the presence of the crystalline phases of interest, all three glasses were oversaturated with one or more key constituents specific for the crystalline phase of interest. HLW-E-SP-05 and HLW-E-SP-06 are oversaturated with respect to iron-rich spinel and HLW-E-ES-02 is oversaturated with respect to eskolaite [2-8]. Characterization data for the three glasses are summarized in Table 2.2, which includes the volume percent of crystalline phase, as well as the nature and particle size of the predominant crystalline phase at various temperatures. Two of the three glasses investigated in this work, HLW-E-SP-05 and HLW-E-SP-06 were selected for DM100 melter testing [2-8]. The third glass, HLW-E-ES-02, which is oversaturated with respect to eskolaite has a relatively high viscosity (see Table 2.2) near the melter operating temperature, and therefore a slightly modified version of this formulation was used for DM100 melter testing [2-8].

\subsection{Experimental Methods}

\subsubsection{Crystal Settling Experiments}

The settling characteristics of different crystal types and glass formulations were investigated experimentally at the crucible scale. Glass samples were held at constant temperature for fixed time periods after which the sample was quenched, sectioned, and analyzed microscopically to determine the distribution of particles. This process was repeated for different time periods $(3.5,7,14$ and 28 hours) at each of three temperatures $\left(1150,1050\right.$, and $\left.950^{\circ} \mathrm{C}\right)$. The crystals that formed were identified by Scanning Electron Microscopy/Energy Dispersive X-Ray Spectroscopy (SEM/EDS) (Table 2.2).

A double-crucible assembly was used to hold the glass melt in the settling experiments (Figure 2.1). The double-crucible assembly consists of a smaller straight-walled alumina crucible $(10 \mathrm{ml})$ placed inside a larger fused silica crucible $(50 \mathrm{ml})$ with the glass melt level sufficient to completely immerse the smaller inner crucible. The double-crucible assembly is designed to minimize Marangoni convection and bubble generation within the inner crucible [2-9]. Once loaded with glass (about 80 grams), the assembly was preheated at $1220^{\circ} \mathrm{C}$ for 20 minutes before being cooled to the pre-determined test temperature for the specified test duration. The assembly was then quenched and cross-sectioned (perpendicular to the glass surface) to produce a petrographic thin section. The sample was then scanned optically into a digital image file and analyzed to determine the spatial distribution of crystals inside the inner crucible. 
The Catholic University of America Vitreous State Laboratory
Crystal Settling, Redox, and Properties of ORP HLW \& LAW Glasses

Final Report, VSL-09R1510-1, Rev. 0

\subsubsection{Measurement of Glass Melt Rheology with Suspended Crystalline Phase}

The rheological properties of three HLW glass melts containing various amounts of crystalline phases (Table 2.2) were characterized for their shear stress and shear rate relationship over a temperature range relevant for potential waste glass melter operation (nominally, 1250, 1150, 1050 and $950^{\circ} \mathrm{C}$ ). A system composed of a viscometer with a rotor (cylindrical or vane) and a cup designed for high temperature application was calibrated using materials of known flow properties [2-10 - 2-12]. A Pt-10\%Rh spindle driven by a Brookfield viscometer, mounted in a support frame with an appropriate heat shield, was used as the sensor for the shear stress at each applied shear rate. A custom-made Pt-10\%Rh vane rotor for high temperature use was calibrated for measurement of the yield stress of a glass melt with suspended crystalline particles. The glass melts were heated to the test temperature in a Pt $10 \% \mathrm{Rh}$ crucible in the hot zone of a tube furnace before characterization. At each of the test temperatures, the steady state shear stress was measured at multiple shear rates.

In a typical measurement, the glass sample was held at a given temperature for the specified duration according to the schedules used in the determination of crystal settling. At the end of the holding period, rheological characterization was performed for the shear stress at a given shear rate. A range of shear rates was used for the determination of the relationship between the shear stress and shear rate under the given conditions. After completion of the measurement, heat treatment of the glass melt continued until the next sampling point, and the rheological data were collected following the same method. In view of the fact that all three HLW glass melts contain a few percent of crystalline phases and that settling of these denser particles would very likely occur (as indicated from the settling data determined separately), a Pt-10\% Rh mechanical stirrer was used to disperse the particles before the first measurement for a given temperature.

\subsection{Crystal Settling Behavior Results}

The compositions and properties of the three HLW glasses are presented in Tables $2.1-2.3$. The settling behavior of crystals in these glass melts was analyzed from the cross sections of test crucibles quenched after a given holding time (3.5 to 28 hours). As shown in Figures 2.2, 2.3, and 2.4, different settling behavior is evident from the overall trends displayed by each glass. Eskolaite, despite forming in a melt of relatively higher viscosity (HLW-E-ES-02), displayed a clear tendency for aggregation and settling, as is evident from both the scanned images (Figure 2.2) and from the optical microscopy images at greater magnification (Figure 2.5). Aggregation of eskolaite is evident after three hours at $950^{\circ} \mathrm{C}$ and the aggregation progressed to about 14 hours. After 28 hours, a considerable amount of crystal aggregates had concentrated in the lower two thirds of the crucible. The degree of aggregation is further enhanced at temperatures of 1050 and $1150^{\circ} \mathrm{C}$. The settling rate is evidently rather high at $1150^{\circ} \mathrm{C}$, as shown in Figure 2.2. The top half of the glass melt was largely free of crystals after 3.5 hours and the settling appeared complete after 28 hours, with a highly concentrated crystalline zone near the bottom and a more or less uniform glass melt above it. 
The Catholic University of America Vitreous State Laboratory
Crystal Settling, Redox, and Properties of ORP HLW \& LAW Glasses Final Report, VSL-09R1510-1, Rev. 0

The settling behavior is more complex in HLW-E-SP-05 that contains predominantly spinel at temperatures above $950^{\circ} \mathrm{C}$ (Figures 2.3, 2.6). A modest level of aggregation developed after 7 hours at $950^{\circ} \mathrm{C}$, which progressed further after 14 hours of idling. Thereafter, the crystal aggregates migrated toward both the top surface and the bottom, leaving the middle region largely free of crystalline phases. Although spinel particles remained well dispersed within the melt at $1050^{\circ} \mathrm{C}$, in contrast to the trend observed at $950^{\circ} \mathrm{C}$, the concentration increased only slightly toward the lower half of the crucible after 3.5, 7, 14 and 28 hours. Aggregation and settling of spinel crystals occurred more extensively at $1150^{\circ} \mathrm{C}$ and particularly after 14 hours and 28 hours. As shown in Figure 2.3, the settling particles produce a concave-upward boundary layer that divides a region enriched with spinel from a region largely free of spinel. As explained below, the occurrence of spinel settling at $1150^{\circ} \mathrm{C}$ and its apparent absence at two other temperatures is influenced by the rheological properties of the fluid with suspended particles.

The settling behavior is simpler for HLW-E-SP-06 at all three temperatures at times up to 7 hours. As is apparent in Figures 2.4 and 2.7, the spinel particles are more or less uniformly dispersed. A modest level of aggregation is visible after 28 hours at $950^{\circ} \mathrm{C}$ but it is mostly concentrated on the walls of the crucible and underneath the glass surface. At $1050^{\circ} \mathrm{C}$, spinel particles displayed gradual concentration toward the bottom of the crucible, leaving behind largely crystal-free glass in the top half of the crucible. The settling rate apparently accelerated at $1150^{\circ} \mathrm{C}$ after 7 hours idling. A layer of settled spinel developed on the bottom of the crucible after 14 hours and 28 hours. The thickness of the layer increased considerably from 14 hours to 28 hours (Figure 2.4).

As an aid for further comparison, the volumetric content of crystals with depth was estimated for each successive $6 \mathrm{~mm}$ segment from a $30 \mathrm{~mm}$ tall glass column. The scanned cross section images, after division into five segments, were analyzed for their luminosity distribution by Photoshop ${ }^{\mathrm{TM}}$ in order to obtain an average volume \% crystal content. However, the reported values should be used solely for comparison purposes due to the complications presented by the different thicknesses of the thin sections (Table 2.3) and the various levels of overlapping of crystals at different depths within a thin section. Nevertheless, the results from the image analysis are useful to identify the trends that may not be apparent at first sight. In agreement with visual observation from the images, the overall distribution of eskolaite from HLW-E-ES-02 obtained by analysis of luminosity does not vary significantly vertically at 950 and $1050^{\circ} \mathrm{C}$, with the exception of dips near the melt surface. At $1150^{\circ} \mathrm{C}$, however, clear concentration gradients are evident from image analysis of samples after 3.5 hours and longer (Figure 2.8). No clear fractionation of spinel particles occurred in HLW-E-SP- 05 at $950^{\circ} \mathrm{C}$ except for a sudden dip in the mid portion of the 28 hours sample. Better defined concentration gradients are apparent for samples at $1050^{\circ} \mathrm{C}$, as shown in Figure 2.9. Luminosity analysis did not yield useful results for samples from $1150^{\circ} \mathrm{C}$ experiments due to strong matrix interference. The spinel distribution in HLW-E-SP-06 is largely flat at $950^{\circ} \mathrm{C}$, and becomes concentrated toward the lower half at $1050^{\circ} \mathrm{C}$ (Figure 2.10). Similar to HLW-E-SP-05, no analysis could be performed for samples from $1150^{\circ} \mathrm{C}$ experiments.

In the Stokes equation approximation, for a given geometry and a similar density difference between the crystal particles and host melt, the largest effects on settling are the particle size (a 
The Catholic University of America Vitreous State Laboratory
Crystal Settling, Redox, and Properties of ORP HLW \& LAW Glasses

Final Report, VSL-09R1510-1, Rev. 0

squared factor) and liquid viscosity (inverse linear). Eskolaite in HLW-E-ES-02 has the largest linear dimension, as identified from samples after 70 hours heat treatment (Table 2.2) and from samples from settling experiments (Table 2.3). Likely due to their large particle size, eskolaite settled rapidly at $1150^{\circ} \mathrm{C}$. At temperatures close to that typical for melter idling operation, aggregation progressed in a few hours accompanied by considerable settling. The origin of the difference in spinel aggregation and settling between glasses HLW-E-SP-05 and HLW-E-SP-06 is unclear. In spite of the different grain size reported from analysis of 70 hours heat treated samples by SEM (Table 2.2), the optical examination of the crystal size from the settling experiments did not indicate a significant difference in the predominant grain size (Table 2.3). It is, however, evident that the spinel crystal particles aggregated considerably in HLW-E-SP-05 but remained largely suspended at all three test temperatures. In contrast, with a lower crystalline phase concentration in HLW-E-SP-06 (Table 2.2), the finely dispersed particles settled more rapidly at almost all temperatures. This suggests the modified apparent viscosity and more complicated flow behavior at high crystal concentrations played an important role in retarding crystal settling in HLW-E-SP-05.

\subsection{Rheological Characterization Results}

Fluid rheology is an important engineering factor, both within the melt pool and for the glass discharge system. Assessment of the processability of a glass melt that contains suspended crystalline particles should, therefore, include measurements of the rheological properties of the fluid and their evolution with time and temperature. For a glass melt system for which nucleation, crystal growth, and subsequent settling occurs on a time scale comparable to the typical melt residence time, the flow properties of the glass melt will evolve with time as well as temperature.

Glasses selected for crystal settling characterization were investigated for their flow behavior as fluid systems with suspended crystalline particles. The results were used to asses the effects on the rheological behavior of changes in crystal content as well as the size and geometry of the predominant crystal particles in the three glasses (cubic spinels in HLW-E-SP-05 and HLW-E-SP06 , and rhombohedral eskolaite in HLW-E-ES-02, see Tables $2.1-2.3$ ). Since the fluid rheology and crystal settling behavior are coupled, the rheological data are useful in interpreting the settling data and vice versa.

The flow properties of the selected HLW glass melts with suspended crystal particles were characterized following VSL technical procedure TPI-GRH for non-Newtonian fluid systems [2-12]. Figures $2.11-2.13$ display the dependence of shear viscosity with shear rate at four temperatures. The raw data (relative torque at a given RPM) and the viscosity at the corresponding shear rate are listed in Tables $2.4-2.6$ for all three glass melts.

Shear thinning is apparent for all three glass melts at all four test temperatures after holding isothermally for up to 24 hours. As reported previously, decreasing viscosity with increasing shear rate is commonly observed for a fluid system with internal structure or suspensions [2-13]. The viscosity of HLW-E-ES-02 dropped by a factor of 35 , from above 1000 poise at a low shear rate of $0.03 / \mathrm{s}$ to 36 poise at $62 / \mathrm{s}$ at $1265^{\circ} \mathrm{C}$, and by factors of 14,9 , and 4 , at 1164,1062 , and $961^{\circ} \mathrm{C}$, 
The Catholic University of America Vitreous State Laboratory
Crystal Settling, Redox, and Properties of ORP HLW \& LAW Glasses Final Report, VSL-09R1510-1, Rev. 0

respectively, at the same two shear rates (Table 2.4, Figure 2.11). For platelets or acicular crystals, realignment in the direction of shearing could result in a smaller resistance to flow. It is known that plastic materials exhibit such a flow behavior with a characteristic shear thinning trend and a finite yield stress. Analysis of the data for shear stress as a function of shear rate collected in this work suggests that for HLW-E-ES-02, this relationship can be adequately described by the Bingham plastic model at all four temperatures and holding times. Table 2.7 lists the fitting parameters for the Bingham model for the experimental data. It is noted that 2 of 15 yield stress values extrapolated from modeling are generally small (less than $10 \mathrm{~Pa}$, as compared to those for typical plastic materials of $10-100 \mathrm{~Pa}$ [2-13]). The yield stress values determined experimentally are listed in Table 2.7 for comparison. Only two melt samples showed signs of a yield stress at 1265 and $1164^{\circ} \mathrm{C}(2$ and $6 \mathrm{~Pa}$, respectively), which are reasonably close to the extrapolated yield stress obtained from the Bingham models (8 and 10 respectively).

The effect of dwell time on viscosity is shown by the viscosity measurement after various hold times at a given shear rate (Table 2.4, Figure 2.14). Little change was observed at temperatures of 1265 and $1164^{\circ} \mathrm{C}$ for a range of shear rates at 2 hours, or at two lower temperatures (1062 and $961^{\circ} \mathrm{C}$ ) for dwell times longer than one hour (1-4 hours and 1-24 hours, respectively). However, the viscosity decreased substantially in the first hour at 1062 and $961^{\circ} \mathrm{C}$ (Table 2.4, Figure 2.14), especially at the lower shear rate $(0.31 / \mathrm{s})$. This suggests a process that occurred rapidly (in less than one hour) at these two temperatures, which became too rapid to be captured at the two higher temperatures. As explained below, the decreasing viscosity with time in HLW-E-ES-02 may be the result of rather fast crystal settling, as shown in the previous section.

The viscosity of HLW-E-SP-05 displayed rather weak shear thinning at 1263 and $1162^{\circ} \mathrm{C}$ after up to two hours and with no obvious time dependence (Table 2.5, Figure 2.12). The effect of shear thinning is more substantial at 1060 and $960^{\circ} \mathrm{C}$ and became better defined after dwell times of more than one hour (Table 2.5 and Figure 2.12). Figure 2.15 shows the evolution of viscosity with time at selected shear rates. Contrary to what was observed in HLW-E-ES-02, the viscosity at a given shear rate increases with time up to 4 hours and then levels off up to the maximum duration of the measurement ( 24 hours).

Analysis of shear stress as a function of shear rate for HLW-E-SP-05 indicated that the Bingham model is adequate at 1263 and $1162^{\circ} \mathrm{C}$. As shown in Table 2.8, the yield stress from the Bingham model at those test conditions is close to, or below $1 \mathrm{~Pa}$, in agreement with the rather weak shear thinning shown in Figure 2.12. In fact, a Newtonian model also represents the data reasonably well. However, the dependence of the shear stress on shear rate is not as simple at the two lower temperatures $\left(1060\right.$ and $\left.960^{\circ} \mathrm{C}\right)$. The more complex Herschel-Bulkley model is needed to account for the curvature displayed over the range of shear rates. The fitting parameters for the Herschel-Bulkley model are listed together with those for the simpler Bingham model in Table 2.8. Note that the nonlinear dependence of shear stress on the shear rate is described by the flow behavior index $n$ in the Herschel-Bulkley model. At $n=1$, the Herschel-Bulkley model reduces to the Bingham model, while at yield stress $\tau_{\mathrm{HB}}=0$, the Herschel-Bulkley model reduces to the Power Law model. A pseudoplastic fluid is always characterized by a flow behavior index of $n<1$. At $1060^{\circ} \mathrm{C}$, the flow behavior index is significantly less than one after one hour, which persisted after two and four hours; the 
The Catholic University of America Vitreous State Laboratory
Crystal Settling, Redox, and Properties of ORP HLW \& LAW Glasses Final Report, VSL-09R1510-1, Rev. 0

corresponding modeled yield stresses ranged from $4 \mathrm{~Pa}$ initially to $25 \mathrm{~Pa}$ after four hours. The experimentally determined yield stress values at $1060^{\circ} \mathrm{C}$ are within a factor of 2 of the values obtained from the Herschel-Bulkley models. It is interesting to note that the yield stress values extrapolated from Bingham model are almost identical to the experimentally measured values. At $960^{\circ} \mathrm{C}$, the curvature of the shear stress vs. shear rate is too large to be accounted by the Bingham plastic model. The values of $n$ for the Herschel-Bulkley model are around 0.7 , with $\tau_{\mathrm{HB}}$ ranging from 2 initially to almost $100 \mathrm{~Pa}$ after 24 hours. However, the yield stress determined experimentally is considerably higher ranging from $606 \mathrm{~Pa}$ initially to $193 \mathrm{~Pa}$ after 24 hours. Again, the extrapolated yield stress values from the Bingham models are closer and are within a factor of two of the experimental values (Table 2.8).

Shear thinning is not as well developed in HLW-E-SP-06 as it is in HLW-E-SP-05. As shown in Tables 2.6, 2.9, and Figure 2.13, the moderate shear thinning observed at $1161^{\circ} \mathrm{C}$ and $1062^{\circ} \mathrm{C}$ occurred only at the lowest shear rates, at which the relative torque values are rather low and therefore subject to relatively large uncertainties. Shear thinning becomes apparent only after 4 hours at $963^{\circ} \mathrm{C}$, as shown by the curves for 4 hours and 24 hours in Figure 2.13. The Bingham model adequately accounts for the dependence of shear stress on shear rate for HLW-E-SP-06 (Table 2.9). In fact, most of the data sets can be modeled well by a Newtonian model in light of the very small yield stress values obtained from curve fitting (Table 2.9). Non-Newtonian flow behavior becomes apparent only for data collected after 2,4 , and 24 hours at $963^{\circ} \mathrm{C}$. Even at $963^{\circ} \mathrm{C}$, no yield stress was detected experimentally. Another difference of HLW-E-SP-06 from HLW-E-SP-05 is the apparent lack of variation of viscosity with time at 1161 and $1062^{\circ} \mathrm{C}$; even at $963^{\circ} \mathrm{C}$, the viscosity of HLW-ESP-06 increases with time up to 4 hours, then levels off for longer times (Figure 2.16).

\subsection{Summary and Conclusions}

The data from crystal settling and melt rheology measurement presents a complex picture of the behavior of glass melts with dispersed crystals. Settling of spinel or eskolaite particles in the selected HLW glass melts did not usually display a clearly defined settling front; more typical were aggregation and gradual concentration. The three HLW glasses show distinctive settling behavior variations with time and temperature. Rheology measurements show non-Newtonian flow behavior for all three melts with suspended crystalline particles. In addition to those extracted from modeling analysis of the relationship between shear stress and shear rate, the yield stress of the crystal-bearing glass melts was also determined by direct measurement.

The results show that the flow behavior of the crystal-bearing HLW melts can be described by either the Bingham plastic model or the more complex Herschel-Bulkley model. On the microscopic scale, a generic plastic material consists of two phases, in proper proportion, with the continuous liquid phase and a 'solid-like' dispersed phase held together by internal cohesion. Below the yield point, plastic materials behave like an elastic body. When the shear stress exceeds the yield point, a plastic material flows. In the present situation, the glass melt provides the continuous liquid matrix while the crystal particles are true solids. The stability of the suspension can be affected by such factors as the surface tension, density difference between the melt and the solid, particle size, 
The Catholic University of America Vitreous State Laboratory
Crystal Settling, Redox, and Properties of ORP HLW \& LAW Glasses Final Report, VSL-09R1510-1, Rev. 0

particle geometry, and the interactions between the particles and aggregation effects.

Table 2.10 summarizes the key observations from this work, including major findings from the crystal settling experiments and rheological characterization. The data collected from this work suggest that, for the crystal particles investigated, a fluid that behaves like Bingham plastic with negligible or small yield stress (HLW-E-ES-02 and HLW-E-SP-06) will likely exhibit considerable settling. However, a fluid that behaves like Herschel-Bulkley model with a large yield stress and pseudoplastic flow curve will more likely maintain the particles in suspension, as was observed for HLW-E-SP-05 at 1050 and $950^{\circ} \mathrm{C}$. Viewed from a engineering perspective, it appears more favorable to develop a suspension system with a yield stress high enough to prevent fast settling of crystalline particles (to achieve a higher waste loading) yet not so high as to prevent flow at the working shear rate. It is interesting, however, that a larger yield stress pseudoplastic flow behavior would emerge for HLW-E-SP-05 but not for HLW-E-SP-06, even though the same type of spinel formed in both systems. The limited data appear to suggest two factors that could be responsible: 1) the overall size of the crystalline phase: as shown in Tables 2.2, 2.3, and 2.10, the predominant crystals are roughly 5 microns across in HLW-E-SP- 05 at 1050 and $950^{\circ} \mathrm{C}$, in which large yield stresses were observed, while in HLW-E-SP06, more particles are 10 microns or larger at the same test temperatures; 2) the content of crystalline particles: the volume \% of spinel in HLW-E-SP-05 is about two times that in HLW-E-SP-06. The relatively higher crystal content and relatively smaller grain size in HLW-E-SP-05 evidently leads to reduced settling and a more stable suspension. Accordingly, HLW-E-ES-02, with relatively low crystal content and considerably larger grain size, showed the most extensive particle settling.

While there are many qualitative similarities, detailed comparison of the present results with previous findings is complicated by differences between the systems studied and ambiguities in the literature data. Mika et. al. [2-14] reported on the rheological behavior of spinel sludge formed from $\mathrm{HLW}$ waste glass melts rich in $\mathrm{Fe}, \mathrm{Cr}$ and Ni. Their baseline glass included $14.08 \mathrm{wt} \% \mathrm{Fe}_{2} \mathrm{O}_{3}$, $1.42 \mathrm{wt} \% \mathrm{Cr}_{2} \mathrm{O}_{3}$, and $3.03 \mathrm{wt} \% \mathrm{NiO}$ [2-14]. The part of glass that was concentrated with spinel sludge was the subject of their rheology study at temperatures from 1094 to $1393^{\circ} \mathrm{C}$. After analyzing the experimental data, Mika et al. [2-14] concluded that the spinel sludge behaves as a rheopectic pseudoplastic liquid. Jiřička and Hrma [2-15] investigated the structural and mechanical properties of another spinel sludge sample and reported that the sludge was pseudoplastic below $1300^{\circ} \mathrm{C}$ and Newtonian above $1300^{\circ} \mathrm{C}$. However, the rheological data reported in these two papers were collected using a disk type rotor for which the shear rate is not well defined. In fact, for such a test geometry, the shear rate varies from near zero at the spindle to a maximum value near the edge. The measured torque therefore reflects the composite effects of the fluid behavior integrated over this range of shear rates. The true rheological behavior of the fluid with shear rate is therefore not determined in such a measurement. Furthermore, the shear rate values designated by Mika et al. [2-14] and Jiřička and Hrma [2-15] are not valid because their calculation was based on the formulas derived for a cylindrical rotor [2-15], whereas their measurements were made with a disk rotor. This likely explains why a very different rheological behavior was observed by Mika et al. [2-16] for the same sludge sample when a cylindrical rotor was used. Mika et al. [2-16] reported, instead of pseudoplastic, a Newtonian behavior, without significant deviation, for two samples containing 11 and 17 vol\% spinel, respectively. In light of the results from the present work, it seems surprising 
The Catholic University of America Vitreous State Laboratory
Crystal Settling, Redox, and Properties of ORP HLW \& LAW Glasses

Final Report, VSL-09R1510-1, Rev. 0

that melts with such large amounts of suspended particles would behave as a Newtonian fluid, especially at low to moderate shear rates. However, it is not possible to further assess the rheological data of Mika et al. [2-16] because the shear rate values used in their work were not reported.

As noted earlier, a further aspect of this work involved direct evaluation of the impact of high crystal contents on melter operation. The two spinel saturated HLW glasses, HLW-E-SP-06 and HLW-E-SP-05, were tested using DM100 melter (Test 1, and Test 2 in [2-8]). HLW-E-ES-05, a glass oversaturated with eskolaite but with lower viscosity than HLW-E-ES-02, was also tested on the DM100 (Test 4 in [2-8]).

The data from melter runs with the two spinel saturated glass melts were complicated by crystallization of hematite $\left(\mathrm{Fe}_{2} \mathrm{O}_{3}\right)$ during the melter processing, which was notably not present in the crucible experiments involving isothermal heat treatment ( 70 hours) or in the crystal settling tests. However, the crystal contents of the glass samples collected either from the discharged glass, dip samples, or bottom suction samples are consistently near or above the target values from the 70-hour isothermal crucible experiments [2-8]. Since no data are available for the crystal contents of the two glass melts in equilibrium with both spinel and hematite, it is not possible to determine, on the basis of crystal \% in glass samples, the impact of possible crystal settling during the melter operation and the subsequent long idling. However, the fact that all of the samples that were collected had crystal yields near or above the target suggest that the crystal settling at the melter idling temperature $\left(950^{\circ} \mathrm{C}\right)$ was not severe for both HLW-E-SP-06 and HLW-E-SP-05. This observation is in general agreement with the conclusion from the crystal settling experiments at $950^{\circ} \mathrm{C}$, which showed that no significant settling was evident after 24 hours. It should be noted, however, that considerable amounts of crystal particles, mostly spinel, accumulated in the collection boats that were fully immersed in the glass pool. There were indications that platelet hematite tended to reside above the spinel sludge that was typically concentrated near the bottom of the Inconel boats. However, the observed spinel sludge was likely affected by the local corrosion of the $\mathrm{Ni}-\mathrm{Cr}-$ Fe alloy (Inconel 601) by the glass melt.

The results from Test 4 [2-8] with a glass melt that was oversaturated with platelet eskolaite are less complicated. All glasses from dip samples or discharged glass samples retained eskolaite with crystal yields between $75 \%$ to over $100 \%$ of the targeted value [2-8]. The occasional occurrence of spinel phase was attributed to carryover from the previous melter run with glass melts that were oversaturated with spinel [2-8]. The high crystal yields suggest that the majority of the eskolaite particles were retained in suspension in the glass melts and crystal settling was not extensive. This observation agrees with settling results for HLW-E-ES- 02 at $950^{\circ} \mathrm{C}$ from the present work. Minor to moderate settling appeared to have developed after extensive aggregation of platelet eskolaite. Similar to the tests of HLW-E-SP-05 and HLW-E-SP-06, large amounts of Ni-rich spinel, instead of eskolaite, were found in the Inconel boat.

On the other hand, suction samples from Test 4 [2-8] (eskolaite) and Test 5 [2-8] (Zn-rich spinel) displayed clear signs of settling of spinel (before Test 4) and eskolaite (before Test 5). As shown from the small scale settling experiments at $1050^{\circ} \mathrm{C}$ and especially at $1150^{\circ} \mathrm{C}$, significant crystal settling occurred within hours under static conditions (e.g., HLW-E-ES-02 at $1150^{\circ} \mathrm{C}$ ). 
The Catholic University of America Vitreous State Laboratory
Crystal Settling, Redox, and Properties of ORP HLW \& LAW Glasses

Final Report, VSL-09R1510-1, Rev. 0

During the normal melter operation (feeding) portion of the melter tests, as compared to the idling portion, the temperature was higher $\left(1150^{\circ} \mathrm{C}\right)$ and melt pool mixing by bubbling was present. Thus, the extent to which limited settling was observed in the melter tests, whereas extensive settling was observed at $1150^{\circ} \mathrm{C}$ in the present (static) tests, likely reflects the effects of the melt pool mixing by bubblers on maintaining the crystal particles in suspension.

In summary, the data from DM100 tests with HLW glass melts with high crystal contents indicate limited crystal settling for either eskolaite or spinel during the normal operation at $1150^{\circ} \mathrm{C}$ and extended idling at $950^{\circ} \mathrm{C}$. In comparison, small scale crystal settling experiment showed minor crystal settling at $950^{\circ} \mathrm{C}$ and moderate to extensive settling at 1050 and $1150^{\circ} \mathrm{C}$ under static conditions. Importantly, although the three crystal-bearing melts displayed rather different settling and rheological behavior in the small scale experiments, no difficulties were encountered in the DM100 melter tests that prevented processing the high crystal content HLW melts. However, further testing would be required to better assess the rate of crystal accumulation and any potential long-term effects on melter operation. 
The Catholic University of America Vitreous State Laboratory
Crystal Settling, Redox, and Properties of ORP HLW \& LAW Glasses Final Report, VSL-09R1510-1, Rev. 0

\subsection{References}

[2-1] "Glass Formulation to Support Melter Runs with HLW Simulants," W.K. Kot, K. Klatt, and I.L. Pegg, VSL-03R3760-2, Rev. 0, Vitreous State Laboratory, The Catholic University of America, Washington, DC, 9/30/03.

[2-2] "The Transport of Xenoliths in Magmas," R.S. Sparks, H. Pinkerton, and R. MacDonald, Earth Planet. Sci. Letters, Vol. 35, 234-238 (1977).

[2-3] "Settling of Spinel in a High Level Waste Glass Melter," P. Hrma, P. Schill, and L. Nemec, PNNL-13747, Pacific Northwest National Laboratory, Richland, WA, January, 2002.

[2-4] "Testing and Modeling the Behavior of Platinoids during Vitrification of High-Level Radioactive Waste - Part 1," W. Lutze, W. Gong, F.C. Perez-Cardenas, K.S. Matlack, I.L. Pegg, and P. Schill, European J. Glass Sci. Tech., 48, 263 (2007).

[2-5] "Testing and Modeling the Behavior of Platinoids during Vitrification of High-Level Radioactive Waste - Part 2," P. Schill, W. Lutze, W. Gong, and I.L. Pegg, European J. Glass Sci. Tech., 48, 276 (2007).

[2-6] "Testing and Modeling the Behavior of Platinoids during Vitrification of High-Level Radioactive Waste - Part 3, W. Gong, W. Lutze, K.S. Matlack, and I.L. Pegg, European J. Glass Sci. Tech., accepted.

[2-7] "Testing and Modeling the Behavior of Platinoids during Vitrification of High-Level Radioactive Waste - Part 4: Effect of Spinel," W. Gong, W. Lutze, and I.L. Pegg, European J. Glass Sci. Tech., accepted.

[2-8] "Effects of High Spinel and Chromium Oxide Crystal Contents on Simulated HLW Vitrification in DM100 Melter Tests," K.S. Matlack, W.K. Kot, W. Gong, W. Lutze, I.L. Pegg and I. Joseph, Final Report, VSL-09R1520-1, Rev. 0, Vitreous State Laboratory, The Catholic University of America, Washington, DC, 6/19/09.

[2-9] "A Crucible Study of Spinel Settling in a High-Level Waste Glass," M. LaMont and P. Hrma, Ceramic Transactions, Vol. 87, 343-348 (1998).

[2-10] "Glass Viscosity and Conductivity", VSL Technical Procedure TPI-GC, Rev. 5, Vitreous State Laboratory, The Catholic University of America, Washington, DC, 3/15/07.

[2-11] "Slurry Rheology Measurement," VSL Technical Procedure TPI-SR, Rev. 4, Vitreous State Laboratory, The Catholic University of America, Washington, DC, 10/18/05. 
The Catholic University of America Vitreous State Laboratory
Crystal Settling, Redox, and Properties of ORP HLW \& LAW Glasses Final Report, VSL-09R1510-1, Rev. 0

[2-12] "Characterization of Rheological Behavior of Waste Glass Melts with Suspended Crystalline Phase," VSL Technical Procedure TPI-GRH, Rev. 0, Vitreous State Laboratory, The Catholic University of America, Washington, DC, 3/18/09.

[2-13] “An Introduction to Food Rheology,” H. G. Muller, Crane, Russak \& Company, Inc., New York, 1973.

[2-14] "Rheology of Spinel Sludge in Molten Glass," M. Mika, P. Hrma, M.J. Schweiger, Ceramics-Silikáty, 44(3) 86-90 (2000).

[2-15] "Structural and Mechanical Response to a Thermo-Rheological History of Spinel Sludge in High-Level Waste Glass,” M. Jiřička and P. Hrma, Ceramics-Silikáty, 46(1) 1-7(2002).

[2-16] "The Effect of Spinel Sludge Aging on its Viscosity," M. Mika, M. Liška, and P. Hrma, Ceramics-Silikáty, 46(4) 148-151 (2002). 
The Catholic University of America Vitreous State Laboratory
Crystal Settling, Redox, and Properties of ORP HLW \& LAW Glasses

Final Report, VSL-09R1510-1, Rev. 0

\section{SECTION 3.0 V, Cr, AND Sn REDOX IN LAW GLASSES}

One of the objectives of the present work was to determine the extent to which waste loadings in the Low Activity Waste (LAW) glass formulations might be increased while excluding iron and titanium as glass former additives. Instead, tin and vanadium were evaluated as potential glass former additives to improve waste loading. Iron and titanium were not used as glass former additives, but were present in the final glass composition in low concentrations because of their presence as impurities in the glass forming chemical additives $\left(\mathrm{Fe}_{2} \mathrm{O}_{3}\right.$ content of $7.68 \mathrm{wt} \%$ in olivine, $0.51 \mathrm{wt} \%$ in kyanite, and $0.11 \mathrm{wt} \%$ in wollanstonite; $\mathrm{TiO}_{2}$ content of $0.12 \mathrm{wt} \%$ in zircon). In addition, a small amount of chromium was also added to the high-alkali LAW glass formulations to minimize corrosion of the chromium rich refractory bricks (K-3). The redox behavior of the four transition metals $(\mathrm{Cr}, \mathrm{Fe}, \mathrm{Sn}, \mathrm{V})$ in glass was studied using spectroscopic techniques. Although iron was present in the glasses only at low concentrations $(<1 \mathrm{wt} \%)$ its redox state could be measured by iron Mössbauer spectroscopy at the VSL using long count times. The measurement of the redox state of iron in the recently prepared glasses allowed its comparison to the iron redox state in glasses previously studied for Hanford LAW vitrification. The redox state of tin was also measured by Mössbauer spectroscopy using a line at the Science Engineering and Education Co., Minneapolis, $\mathrm{MN}$. The redox state of vanadium and chromium were assessed together by X-ray absorption spectroscopy using a beam line at the Brookhaven National Laboratory. Both X-ray Absorption Near Edge Structure (XANES) and Extended X-ray Absorption Fine Structure (EXAFS) were used to study the coordination and redox state of $\mathrm{Cr}$ and $\mathrm{V}$ in LAW glasses.

LAW feeds contain significant amounts of nitrates and nitrites, which are strong oxidants. Although the LAW feeds also contain various organics, the oxidants are generally present in considerably higher concentrations than the reductants in tanks such as AN-105, AP-101, AZ-101 and AZ-102 and in moderately higher concentrations in higher organics feeds such as in waste tank AN-102. High levels of nitrates and nitrites, without adequate amounts of reductants to counteract their effects, tend to cause foaming in the melt pool during waste processing, which can lead to operational difficulties and reduced waste processing rates. In order to mitigate this issue, sugar is added to the LAW feeds to counterbalance the effects of the excess oxidants according to a protocol that has been developed and demonstrated by VSL/EnergySolutions [3-1-3-27]. The redox state of the resulting glasses was previously determined by measuring the ratio of reduced iron to total iron, $\mathrm{Fe}^{2+} /\left(\mathrm{Fe}^{2+}+\mathrm{Fe}^{3+}\right)$. Melter tests have shown that at the sugar addition recommended by VSL/EnergySolutions, the product LAW glasses typically have 3\% or less of the iron in the reduced $\mathrm{Fe}^{2+}$ state. However, since the sugar addition to LAW feeds is part of the WTP LAW vitrification process control strategy, the effects of normal variations in the sugar addition as well as off-normal conditions need to be considered. From a glass property perspective, the largest potential impact would correspond to an excess sugar addition, which would lead to larger than planned redox ratios. This is so because changes in the redox ratio essentially correspond to changes in glass composition because as the redox ratio increases, a larger fraction of the iron is present as $\mathrm{FeO}$ and a smaller fraction is present as $\mathrm{Fe}_{2} \mathrm{O}_{3}$ and these species have quite different effects on glass properties. In 
The Catholic University of America Vitreous State Laboratory
Crystal Settling, Redox, and Properties of ORP HLW \& LAW Glasses Final Report, VSL-09R1510-1, Rev. 0

contrast, if the redox ratio is smaller than planned, corresponding to a deficit in the sugar addition, the maximum possible compositional impact is to decrease the $\mathrm{FeO}$ content from about $3 \%$ of the total iron to zero, which would have a negligible effect on glass properties ${ }^{1}$. Accordingly, in the present work, as was done in past similar tests [3-28], glass samples were treated to obtain different redox ratios and characterized.

The $\mathrm{Fe}^{2+} / \mathrm{Fe}^{3+}$ redox couple provides a convenient probe of the redox state of waste glasses since iron is quite prevalent in typical HLW streams. It was the subject of several studies with the Savannah River borosilicate glass melts [3-29 - 3-35]. However, in the case of Hanford LAW, because of the very high $\mathrm{pH}$ of the LAW material, the iron content is very low. Consequently, if iron is not added as a glass former, both a redox probe and a potential redox buffer have been removed. Instead, if vanadium is added to improve sulfur incorporation, the $\mathrm{V}^{4+} / \mathrm{V}^{5+}$ couple could provide a potential replacement. However, previous studies with vanadium in LAW glasses by $\mathrm{VSL}$ /EnergySolutions have shown that, at sufficiently high concentrations, vanadium increases melt foaming, which can result in significantly reduced melt rates and longer melter down-time. Consequently, there is a need to better understand the redox behavior and foaming characteristics of vanadium-containing LAW glasses and the amounts of vanadium that can be added to LAW glasses before deleterious foaming effects ensue. $\mathrm{Cr}$ and $\mathrm{Sn}$ were also studied to compare their behavior in Hanford LAW glasses to those reported previously [3-31]. Four LAW glasses were prepared and heat treated under different conditions expected to provide a range of redox ratios, and the redox states of iron, vanadium, tin and chromium were determined.

\subsection{LAW Glass Sample Preparation}

A total of four glass compositions were selected for redox studies. Since large quantities of glass are needed for these studies, discharge glass samples from melter tests were collected and used. Target and analyzed compositions of the glasses used in the redox studies are given Tables 3.1. Designations of the glass compositions and identifications of the melter discharge glasses also are given in Table 3.1. Three melter glass samples, DVW-G-123B, Q10-G-136D, and Z10-G-60C (see Table 3.1 for compositions), were used to study the redox behavior of vanadium and chromium. The target $\mathrm{Na}_{2} \mathrm{O}$ concentration in these glasses varies from 10 to $22 \mathrm{wt} \%$, with decreases mostly in the $\mathrm{Li}_{2} \mathrm{O}$, and $\mathrm{SiO}_{2}$ concentrations as the $\mathrm{Na}_{2} \mathrm{O}$ concentration increases. Since tin is added to the $\mathrm{LAW}$ glasses to improve their chemical durability, the target glass composition used in tin redox studies has the highest alkali content of $24 \mathrm{wt} \% \mathrm{Na}_{2} \mathrm{O}$ and $0.54 \mathrm{wt} \% \mathrm{~K}_{2} \mathrm{O}$.

About $500 \mathrm{~g}$ samples of the melter glasses were collected and re-melted in a Pt crucible. Glass samples with different redox states were obtained by bubbling a mixture of $\mathrm{CO}$ and $\mathrm{CO}_{2}$ gases (CO flow rate at $30 \mathrm{ml} / \mathrm{min}$ and $\mathrm{CO}_{2}$ at $20 \mathrm{ml} / \mathrm{min}$ ) and collecting samples after various periods of

\footnotetext{
${ }^{1}$ For example, if the glass has $10 \mathrm{wt} \%$ total iron oxide (which is conventionally reported as $\mathrm{Fe}_{2} \mathrm{O}_{3}$ ) and the redox ratio is $3 \%$, the glass contains $0.3 \mathrm{wt} \% \mathrm{FeO}$ and $9.7 \mathrm{wt} \% \mathrm{Fe}_{2} \mathrm{O}_{3}$. The worst case in terms of a sugar deficit is $0.00 \mathrm{wt} \% \mathrm{FeO}$ and $10.00 \mathrm{wt} \% \mathrm{Fe}_{2} \mathrm{O}_{3}$, and therefore the impact on glass properties is negligible.
} 
The Catholic University of America Vitreous State Laboratory
Crystal Settling, Redox, and Properties of ORP HLW \& LAW Glasses Final Report, VSL-09R1510-1, Rev. 0

bubbling, typically at intervals of 30 minutes. The three glasses containing vanadium were subjected to redox treatment by bubbling gas for a maximum of 390 minutes, whereas the glass containing tin was treated for a maximum of 510 minutes. Melt samples were periodically taken from the crucible, typically at 30 minute intervals, so that a series of glasses with different redox states were obtained. The samples collected after bubbling were identified with the suffix "REn", where $\mathrm{n}$ corresponds to the order in which the samples were collected from the melt (see Table 3.2). In the redox treatment of DVW-G-123B and Z10-G-60C glasses, one set of fresh melter glass samples was used to prepare redox samples with bubbling redox treatment times varying from 0 to 210 minutes at 30 minute intervals. A second set of fresh melter glass samples was used to prepare redox samples with bubbling redox treatment times varying from 210 to 390 minutes at 90 minute intervals.

Iron redox state was determined by ${ }^{57} \mathrm{Fe}$ Mössbauer spectroscopy using equipment and procedures available at the VSL. Tin redox state was determined by ${ }^{119 \mathrm{~m}} \mathrm{Sn}$ Mössbauer spectroscopy at the Science Engineering and Education Company of Minneapolis, MN. Vanadium and chromium redox states were studied using a synchrotron beam at the Brookhaven National Laboratory, Brookhaven, NY.

Iron redox states in a selected number of glass samples were determined by Mössbauer spectroscopy (see Table 3.2). Due to their low iron content, collection of Mössbauer spectra required count times of two to four weeks each. The sample that showed the highest reduction of iron (R10G155BRE8) was analyzed for its tin redox state. Finally, due to the limited run time available for data collection at the synchrotron facility, only 21 out of the 31 glass samples available for investigation of vanadium and chromium redox states were studied. The samples were selected such that the range of redox conditions used in sample preparation was covered.

As the glass samples became more reduced, their color changed from a lime green to a darker emerald green, likely due to redox changes in iron, vanadium, and chromium.

\subsection{Iron Redox Evaluation by Mössbauer Spectroscopy}

${ }^{57} \mathrm{Fe}$ Mössbauer spectroscopy is a sensitive technique to determine the iron redox ratio in glass samples and can be used at Fe concentrations as low as $0.5 \mathrm{wt} \%$. However, when the $\mathrm{Fe}$ content of the glass is low $(<1 \mathrm{wt} \%)$, the Mössbauer spectrum becomes noisy and requires long count times (two to four weeks) to collect useful data, depending on the specific iron concentration in the glass and strength of the ${ }^{57} \mathrm{Co}$ Mössbauer source. In the present case, target iron oxide concentrations (expressed as $\mathrm{Fe}_{2} \mathrm{O}_{3}$ ) in the glass samples varied from $0.24 \mathrm{wt} \%$ to $1.15 \mathrm{wt} \%$.

A Ranger MS-1200 Mössbauer Spectrometer equipped with a ${ }^{57}$ Co source in rhodium matrix was used to collect the iron Mössbauer spectra. The method involves the collection of spectra showing gamma absorption as a function of Doppler velocities. The calibration of the center shift and the quantification of areas under the peaks corresponding to $\mathrm{Fe}^{2+}$ and $\mathrm{Fe}^{3+}$ are performed using software supplied by the manufacturer. The isomeric shift (or Doppler shift compared to the source energy) was calibrated using the National Institute of Standards and Technology (NIST) Standard 
The Catholic University of America Vitreous State Laboratory
Crystal Settling, Redox, and Properties of ORP HLW \& LAW Glasses Final Report, VSL-09R1510-1, Rev. 0

Reference Material (SRM) 1541 iron metal foil. Calibration standards for which the Fe oxidation state is known were used to calibrate the iron redox measurements. Three reference standards with known iron redox ratios $\left(\mathrm{Fe}^{2+} / \mathrm{Fe}_{\text {total }}\right)$ were used to develop a calibration curve: SRL-EA glass from Corning Glass Works reported in WSRC-TR-92-346, page 9, an Obsidian Rock (NIST SRM 278), and a Basalt Rock (NIST SRM 688) of respective $\mathrm{Fe}^{2+} / \mathrm{Fe}_{\text {total }}$ ratios of $0.20,0.74$ and 0.82 . All measurements were performed at room temperature.

${ }^{57} \mathrm{Fe}$ Mössbauer spectra were obtained for two reduced LAW glasses from each of the series R10-G-155B (with tin and chromium) and DWV-G-123B (with vanadium and chromium), as well as for the parent melter glass R10-G-155B. Results of the redox determinations are summarized in Table 3.2. No reduced iron was identified in melter glass R10-G-155B but the counting statistics were too poor to confirm if any $\mathrm{Fe}^{2+}$ was present. The spectra were acquired over many weeks as both glasses contain only about $1 \mathrm{wt} \% \mathrm{Fe}_{2} \mathrm{O}_{3}$. The spectra (shown in Figure 3.1) indicate that the redox ratio $\left(\mathrm{Fe}^{2+} / \mathrm{Fe}_{\text {tot }}\right)$ reached about 0.67 in R10G155BRE6 and remained at 0.68 after 510 minutes of $\mathrm{CO} / \mathrm{CO}_{2}$ bubbling. In DWV-G-123B, it reached 0.47 after 60 minutes of $\mathrm{CO} / \mathrm{CO}_{2}$ bubbling and decreased to $0.31 \mathrm{Fe}^{2+} / \mathrm{Fe}_{\text {tot }}$ after being subjected to 390 minutes of $\mathrm{CO} / \mathrm{CO}_{2}$ bubbling. These measurements can be related to oxygen fugacity in the melt as reported by Schreiber et al. in a study of electromotive force series in a borosilicate glass-forming melt at $1150{ }^{\circ} \mathrm{C}[3-29,3-35]$ :

$$
-\log \left(\frac{\mathrm{Fe}^{2+}}{\mathrm{Fe}^{3+}}\right)=\frac{1}{4} \log \left(\mathrm{fO}_{2}\right)-1.7
$$

The imposed oxygen fugacity estimated from iron Mössbauer spectroscopy from two glasses containing iron (0.67 and 0.47 as $\mathrm{Fe}^{2+} / \mathrm{Fe}_{\text {tot }}$; see Table 3.2) are $\mathrm{fO}_{2} \approx 10^{-8}$ and $10^{-6}$ respectively. As presented in Figure 3.2 (from Schreiber et. al [3-34]), this oxygen fugacity also predicts a very low redox ratio for tin $\left(\mathrm{Sn}^{2+} / \mathrm{Sn}^{4+}\right)$, but a similar or slightly lower redox ratio for vanadium $\left(\mathrm{V}^{4+} / \mathrm{V}^{5+}\right)$ as compared to iron. It also predicts that chromium will be found mostly as reduced $\left(\mathrm{Cr}^{3+}\right)$. It must be noted that Schreiber's study used transition metal oxide concentrations of about $1 \mathrm{wt} \%$ only, and assumes that the dilution of redox couple does not affect the oxide ion activity.

\subsection{Tin Redox Evaluation by Mössbauer Spectroscopy}

Tin as a potential glass former additive for Hanford LAW was first considered in work performed at VSL in 1999, while studying the effect of various group IV metals in the Periodic Table on LAW glasses [3-36]. Tin was observed to improve the VHT performance of LAW glasses but also to decrease sulfate solubility [3-37-3-39]. Since increasing sulfate solubility was the main focus of the glass development efforts at that time, less effort was directed at compositions containing tin. However, since recent projections show higher sodium additions in pretreatment at Hanford, there is more interest in increasing sodium loadings in LAW glasses, which makes glass compositions with tin potentially more valuable. Amongst the four waste types studied in the present work, AN-105 is alkali limited and it is in this glass formulation that tin was considered as an additive. Titanium, zirconium, and tin have certain similarities in the electronic structure $\left(\mathrm{d}^{2} \mathrm{~s}^{2}\right.$ for titanium and zirconium and $\mathrm{d}^{10} \mathrm{~s}^{2} \mathrm{p}^{2}$ for tin) which leads to some similarity in their properties. 
The Catholic University of America Vitreous State Laboratory
Crystal Settling, Redox, and Properties of ORP HLW \& LAW Glasses Final Report, VSL-09R1510-1, Rev. 0

Zirconia is added primarily to improve the chemical durability of the glass, but it also tends to cause zircon crystallization if added in excess of about $5 \mathrm{wt} \%$. Substituting tin oxide for zirconia presents the advantage of potentially improving leach resistance without increasing the tendency for crystallization. The structural role of zirconium in borosilicate glasses has been the subject of many studies [3-40 - 3-42]. The results of synchrotron X-ray absorption studies of the structural role of tin in borosilicate, potassium aluminosilicate, and commercial float glasses have been recently reported [3-43]. Since tin may be present in glasses at two valence states, $\mathrm{Sn}^{2+}$ and $\mathrm{Sn}^{4+}$, the redox state of the glass also may be important in evaluating the effect of Sn on glass properties. From a series of glasses with varying concentrations of zirconium and tin, to study their sulfate solubility and glass durability (mainly VHT and PCT), formulation ORPLA15 was selected for DM10 melter testing in 2007 [3-44]. Glass samples from the melter test were remelted and bubbled with $\mathrm{CO}$ and $\mathrm{CO}_{2}$ gases to obtain samples with various redox states.

Since a Sn Mössbauer source was not available at the VSL, the measurement was done at Science Engineering and Education Company of Minneapolis, MN. For this measurement, the sample that showed the highest iron reduction (R10G155BRE8) was selected. A Mössbauer spectrum was collected using a ${ }^{119 m} \mathrm{Sn}$ source and is shown in Figure 3.3. The spectrum was analyzed for the concentrations of $\mathrm{Sn}^{2+}$ and $\mathrm{Sn}^{4+}$ by determining the areas under the respective peaks. This analysis showed $3 \% \mathrm{Sn}^{2+}$ and $97 \% \mathrm{Sn}^{4+}$ in the sample using doublet fitting as previously reported [3-45, 3-46]. This sample has an iron redox ratio $\left(\mathrm{Fe}^{2+} / \mathrm{Fe}_{\text {total }}\right)$ of 0.68 . The measured redox results for iron and tin in this glass sample are consistent with the predictions from Schreiber [3-31 3-34] based on redox state measurements and the predictions based on the electrode potentials of $\mathrm{Sn}^{2+} / \mathrm{Sn}^{4+}$ and of $\mathrm{Fe}^{2+} / \mathrm{Fe}^{3+}$ reported by Duffy [3-47].

\subsection{Vanadium and Chromium X-ray Absorption Spectroscopy (XAS)}

Vanadium has been reported to be beneficial in improving the sulfate solubility in waste glasses [3-48]. Vanadium was used in some of the early LAW formulations [3-1, 3-2, 3-49] to determine its effect on sulfur solubility and retention in the glass. Even though addition of vanadium improved acceptable sulfate concentrations in the melter feed, glass melt foaming also was observed as the vanadium concentration was increased [3-2]. However, vanadium continued to be used as a glass former additive of choice when pursuing higher waste loading for LAW streams with high sulfur contents [3-50-3-53]. The valence state and local environment of vanadium in the glasses prepared at VSL have been studied by synchrotron X-ray absorption spectroscopy [3-54, 3-55] and indicate that vanadium mostly exists in these glasses as tetra-coordinated $\mathrm{V}^{5+}$, but penta-coordinated $\mathrm{V}^{4+}$ is also present when larger amounts of sugar are added to the feed. Since LAW feeds contain large amounts of nitrates, sugar is added as a reductant to control the glass redox state. Foaming of highly oxidized LAW melts can have substantial deleterious effects on melter operations. Since iron is a major component in the majority of waste glasses, the $\mathrm{Fe}^{2+} / \mathrm{Fe}^{3+}$ couple is typically used to monitor glass redox state, and acceptable processing ranges have been developed in terms of the iron redox ratio. For glasses that contain little or no iron, study of the redox state of vanadium is of importance in that it can potentially provide another redox couple that can be used to monitor and control the redox state of the glass melt. Therefore, a series of vanadium containing glasses with 
The Catholic University of America Vitreous State Laboratory
Crystal Settling, Redox, and Properties of ORP HLW \& LAW Glasses Final Report, VSL-09R1510-1, Rev. 0

different redox states were prepared and characterized to better understand the behavior of vanadium in LAW glasses and to compare the behavior of iron and vanadium.

X-ray absorption spectra were collected at Beam Line X23B at the National Synchrotron Light Source, Brookhaven National Laboratory, to characterize the vanadium (V) and chromium $(\mathrm{Cr})$ environments in three sets of LAW glasses subjected to redox heat treatment with bubbling. For each sample, using the beam line's silicon (111) double crystal monochromator, data were collected in the energy range from 5340 to $6050 \mathrm{eV}$, which includes the $\mathrm{V}$ and $\mathrm{Cr} \mathrm{K}$-absorption edges near 5465 and $5989 \mathrm{eV}$, respectively. To minimize self-absorption effects, each standard and glass sample was ground, sieved and a layer of particles one absorption-length thick was placed between two pieces of transparent tape. According to Beer's Law: $\mathrm{I}=\mathrm{I}_{0} \mathrm{e}^{-\mu t}$, where $\mathrm{I}_{0}=$ incident beam intensity, $\mathrm{I}=$ transmitted beam intensity, $\mu=$ absorption coefficient of the sample, and $t=$ sample thickness; one absorption length is where: $\mu \mathrm{t}=1$. The flat tape sample was positioned at a $45^{\circ}$ angle with respect to the $2 \mathrm{~mm} \times 2 \mathrm{~mm}$ incident X-ray beam from the monochromator. Fluorescence spectra were gathered for each standard and glass investigated, where the incident $\mathrm{X}$-ray beam intensity $\left(\mathrm{I}_{0}\right)$ and fluorescence intensity from the sample $\left(\mathrm{I}_{\mathrm{f}}\right)$ were measured by ion chambers flushed with nitrogen $\left(\mathrm{I}_{0}\right)$ and $\operatorname{argon}\left(\mathrm{I}_{\mathrm{f}}\right)$. For energy calibration, a $\mathrm{V}$ and $\mathrm{Cr}$ foil reference transmission spectrum was measured in parallel with each spectrum collected for a sample; the foil spectra used the air scattered X-ray intensity from the incident beam and a p.i.n. diode detector [3-56] positioned behind the foils that measured reference intensity $\left(I_{R}\right)$. The absorption coefficient of a sample is proportional to $I_{\mathrm{f}} / I_{0}$ at a particular energy; $\mu$ for the reference foils is proportional to $\ln \left(\mathrm{I}_{0} / \mathrm{I}_{\mathrm{R}}\right)$.

An X-ray absorption spectrum depicts changes in $\mu$ of a sample over an energy range and is divided into two regions: the X-ray absorption near edge structure (XANES), which includes the absorption edge of the element of interest, and the extended X-ray absorption fine structure (EXAFS). The slope of the absorption edge rise, and correspondingly, the edge energy (typically, measured half way up the edge step) is sensitive to the valence of the absorbing element (in this case, $\mathrm{V}$ or $\mathrm{Cr}$ ), where edge energies increase with higher valence. Absorption edge features are also sensitive to the local atomic environment surrounding the absorbing element. EXAFS oscillations, by convention, are extracted from approximately $20 \mathrm{eV}$ beyond the absorption edge to higher energies. In many instances, EXAFS oscillations are dominated by single scattering effects from the arrangement of atoms surrounding the absorber. EXAFS data are analyzed to quantitatively determine average bond distance ( $\mathrm{r}(\AA))$, coordination number (n (atoms)), and disorder (DebyeWaller factor or $\sigma^{2}\left(\AA^{2}\right)$ ) of shells of atoms around the absorbing atom.

All of the vanadium glasses studied are based on melter glasses DVW-G-123B, Q10-G136D, and Z10-G-60C (see Table 3.1), where the target $\mathrm{Na}_{2} \mathrm{O}$ content varies from 10 to $22 \mathrm{wt} \%$, with decreases mostly in the $\mathrm{Li}_{2} \mathrm{O}$, and $\mathrm{SiO}_{2}$ concentrations as the $\mathrm{Na}_{2} \mathrm{O}$ concentration increases.

Five crystalline standards were also measured to model the $\mathrm{V}$ and $\mathrm{Cr}$ valences and environments in the glasses investigated. Phase identification of these materials was verified by powder X-ray diffraction. The vanadium standards include: vanadinite, $\mathrm{Pb}_{5}\left(\mathrm{VO}_{4}\right) \mathrm{Cl}$, where $\mathrm{V}^{5+}$ is in $\mathrm{VO}_{4}$ tetrahedra [3-57], cavansite, $\mathrm{Ca}(\mathrm{VO}) \mathrm{Si}_{4} \mathrm{O}_{10} 4\left(\mathrm{H}_{2} \mathrm{O}\right)$, where $\mathrm{V}^{4+}$ is in $\mathrm{VO}_{5}$ units [3-58], and 
The Catholic University of America Vitreous State Laboratory
Crystal Settling, Redox, and Properties of ORP HLW \& LAW Glasses Final Report, VSL-09R1510-1, Rev. 0

roscoelite, $\mathrm{K}(\mathrm{V}, \mathrm{Mg}, \mathrm{Al})_{2} \mathrm{AlSi}_{3} \mathrm{O}_{10}(\mathrm{OH})_{2}$, where $\mathrm{V}^{3+}$ is in $\mathrm{VO}_{6}$ octahedra [3-59]. The chromium standards include: crocoite $\left(\mathrm{PbCrO}_{4}\right)$, where $\mathrm{Cr}^{6+}$ is in $\mathrm{CrO}_{4}$ tetrahedra [3-60], and uvarovite $\left(\mathrm{Ca}_{3} \mathrm{Cr}_{2} \mathrm{Si}_{3} \mathrm{O}_{12}\right)$, where $\mathrm{Cr}^{3+}$ is in $\mathrm{CrO}_{6}$ octahedra [3-61].

X-ray absorption data for all samples were processed and analyzed using program IFEFFIT [3-62]. The X-ray absorption spectrum for each sample is an average of at least two data sets that were initially processed using standard pre-edge background subtraction, edge-step normalization, and energy calibration procedures. Direct comparisons could then be made among XANES data from all samples to an energy accuracy of $\pm 0.4 \mathrm{eV}$. XANES data for the glasses were fit using the corresponding spectra from the standards to determine the $\mathrm{V}$ and $\mathrm{Cr}$ valence distributions for each glass. To produce the EXAFS data for analysis, a spline function was fit to, and then subtracted from the edge-normalized XAS data, from approximately 35 to $500 \mathrm{eV}$ past the absorption edge. Energy values in $\mathrm{eV}$ were converted to $\mathrm{k}$ in $\AA^{-1}$ (using the equation: $\mathrm{k}=\sqrt{ }\left(2 \mathrm{~m}\left(\mathrm{E}-\mathrm{E}_{0}\right) /(\mathrm{h} / 2 \pi)^{2}\right)$, where: $\mathrm{m}=$ electron mass, $\mathrm{E}=$ photon energy of incident $\mathrm{X}$-rays, $\mathrm{E}_{0}=$ energy where electron momentum is zero, and $\mathrm{h}=$ Planck's constant) [3-63], and the resulting $\chi(\mathrm{k})$ data were $\mathrm{k}^{2}$-weighted; this weighting emphasizes the higher energy- or k-range of the EXAFS data, which typically improves the analysis results. The $\mathrm{k}^{2} \chi(\mathrm{k})$ data were then Fourier transformed over the $2.0 \leq \mathrm{k} \leq 10.5 \AA^{-1}$ range using $0.5 \AA^{-1}$ Hanning windows on the upper and lower limits of the data to minimize termination artifacts in the resulting partial radial distribution function (RDF); details of the Hanning window function and its effect on the resulting partial RDF are provided in reference [3-64], p. 231-233. Peaks in the RDFs correspond to shells of atoms surrounding vanadium or chromium (Figure 3.7), where r, $n$, and $\sigma^{2}$ for each atomic shell can be obtained from EXAFS fitting procedures [3-62, 3-63]. The position of each peak in the RDF is phase-shifted to lower $r$ by 0.2 to $0.3 \AA$ with respect to the actual bond distance.

The period of EXAFS oscillations in $\chi(\mathrm{k})$ data determines $r$, where shorter periods indicate longer average bond distances, which would shift corresponding RDF peaks to larger $r$-values. EXAFS oscillation amplitudes determine the two correlated parameters $n$ and $\sigma^{2}$. Larger EXAFS amplitudes indicate larger $n$-values and correspond to larger amplitude RDF peaks. Damping of oscillations from low to high $\mathrm{k}$-values in the EXAFS data determines the magnitude of $\sigma^{2}$; more strongly damped EXAFS oscillations correspond to larger $\sigma^{2}$ and wider RDF peaks at half maxima. Assuming that all $\mathrm{V}$ and $\mathrm{Cr}$ atoms are surrounded by oxygen atoms within each sample analyzed in this study, $r$ is the average $\mathrm{V}-\mathrm{O}$ or Cr-O nearest-neighbor distance and $n$ is the average number of oxygen atoms surrounding all $\mathrm{V}$ or Cr environments. The Debye-Waller factor $\left(\sigma^{2}\right)$ is a measure of the average positional and thermal disorder around $\mathrm{V}$ - or Cr-sites in each sample. For V-sites that have narrow V-O distance distributions, the corresponding $\sigma^{2}$ would be small; an example is vanadinite where all V-O distances are near $1.70 \AA$. For V-sites that have broad V-O distance distributions, $\sigma^{2}$ would be larger; an example is cavansite where nearest-neighbor V-O distances range from 1.59 to $1.99 \AA$. At higher temperatures, EXAFS oscillation damping would be more pronounced, resulting in larger $\sigma^{2}$-values. 
The Catholic University of America Vitreous State Laboratory
Crystal Settling, Redox, and Properties of ORP HLW \& LAW Glasses

Final Report, VSL-09R1510-1, Rev. 0

\subsubsection{XANES Analysis Results}

XANES fitting analyses for the glasses indicate that as $\mathrm{Na}_{2} \mathrm{O}$ content decreases, both $\mathrm{V}$ and $\mathrm{Cr}$ are on average more reduced (Figures 3.4 to 3.6). The behavior of $\mathrm{V}$ and $\mathrm{Cr}$ valence distributions in the glasses with respect to the elapsed $\mathrm{CO} / \mathrm{CO}_{2}$ bubbling times are significantly different. The $\mathrm{V}$ XANES features do not change much from the most oxidized parent glass to the most reduced glasses, as observed earlier for borosilicate glasses [3-54]. However, Cr XANES show large variations as the melt is exposed to more $\mathrm{CO} / \mathrm{CO}_{2}$ bubbling. The reduced species contents for $\mathrm{V}$ and $\mathrm{Cr}$ are closest to each other in the Na-rich parent glass (Z10-G-60C) (Figure 3.4), and then diverge to where $\mathrm{Cr}^{3+} / \mathrm{Cr}_{\text {total }}$ is over four times larger than $\mathrm{V}^{4+} / \mathrm{V}_{\text {total }}$ in the Na-poor parent glass (DWV-G123B) (Figure 3.6).

\section{Vanadium XANES}

The $\mathrm{V}$ absorption edges for all glasses studied can be described as a linear combination of the XANES for vanadinite $\left(\mathrm{V}^{5+} \mathrm{O}_{4}\right)$ and cavansite $\left(\mathrm{V}^{4+} \mathrm{O}_{5}\right)$, as shown earlier [3-54]. XANES fitting results indicate that vanadium valence distributions in the Z10-G-60C and Q10-G-136D glasses vary from near 6 to $14 \%$ vanadium as $\mathrm{V}^{4+}$. DWV-G-123B glasses are generally more reduced and show the widest $\mathrm{V}$ valence variation of all glasses: from 15 to $34 \% \mathrm{~V}^{4+}$ (see Figure 3.6). The $\mathrm{V}^{4+}$ fraction in the $\mathrm{Z10}-\mathrm{G}-60 \mathrm{C}$ series generally increases with $\mathrm{CO} / \mathrm{CO}_{2}$ bubbling time from the parent glass to Z10G60CRE7 glass (seven 30 minute bubbling intervals), where the valence distributions change is slightly larger than the uncertainty calculated from the fitting procedure. The samples subjected to longer $\mathrm{CO} / \mathrm{CO}_{2}$ bubbling (Z10G60CRE8 through Z10G60CRE10), where the parent glass was initially exposed continuously to 210 minutes of bubbling, contain slightly lesser $\mathrm{V}^{4+}$ fractions than glasses in the series that were exposed to six and seven 30 minute bubbling intervals (Figure 3.4). The Q10-G-136D glasses also indicate a general increase in $\mathrm{V}^{4+}$ content as $\mathrm{CO} / \mathrm{CO}_{2}$ bubbling time increases (Figure 3.5). The DWV-G-123B glass shows the maximum amount of reduction for the sample subjected to bubbling for 60 minutes (DWVG123BRE2), while most glass samples exposed to longer bubbling times as well as the parent glass are less reduced (Figure 3.6). The DWVG123BRE8 sample exposed to 210 minutes of continuous bubbling has similar V valence distribution as the parent glass, whereas DWVG123BRE10 exposed to 390 minutes of $\mathrm{CO} / \mathrm{CO}_{2}$ bubbling showed slightly higher concentration of reduced vanadium.

\section{Chromium XANES}

The Z10-G-60C and Q10-G-136D data can be fit by a linear combination of the XANES for crocoite $\left(\mathrm{Cr}^{6+} \mathrm{O}_{4}\right)$ and uvarovite $\left(\mathrm{Cr}^{3+} \mathrm{O}_{6}\right)$. However, other reduced $\mathrm{Cr}$ valences (such as 5+, 4+, and $2+)$ may be present in these glasses. The fitting results generally indicate that $\mathrm{Cr}$ valence distributions become more reduced as $\mathrm{CO} / \mathrm{CO}_{2}$ bubbling time increases (Figures 3.4 - 3.6). Similar to the $\mathrm{V}$ behavior in Z10-G-60C, Cr XANES for Z10G60CRE8 (210 minutes of continuous CO/CO bubbling) and Z10G60CRE10 indicate slightly less reduced $\mathrm{Cr}$ valence distribution than Z10G60CRE7 (210 minutes of $\mathrm{CO} / \mathrm{CO}_{2}$ bubbling from seven 30 minute intervals) (Figure 3.4). 
The Catholic University of America Vitreous State Laboratory
Crystal Settling, Redox, and Properties of ORP HLW \& LAW Glasses

Final Report, VSL-09R1510-1, Rev. 0

The concentration of reduced $\mathrm{Cr}$ is the highest in the DWV-G-123B series glass samples, where the parent glass shows $0.85 \mathrm{Cr}^{3+} / \mathrm{Cr}_{\text {total }}$ (Figure 3.6). XANES of the DWV-G-123B glasses exposed to any bubbling show no evidence of $\mathrm{Cr}^{6+}$, and glasses exposed to longer $\mathrm{CO} / \mathrm{CO}_{2}$ bubbling times have edges that continue to shift to lower energies than the uvarovite edge. This trend probably indicates $\mathrm{Cr}^{2+}$ populations in these glasses, similar to that observed for silicate glasses synthesized under extreme reducing conditions [3-64]. Unfortunately, a $\mathrm{Cr}^{2+}$ crystalline standard was not available; as a result, the reduced species content could only be shown as $100 \% \mathrm{Cr}^{3+}$ for the five reduced DWV-G-123B glasses used in this study. More details about the distribution of $\mathrm{Cr}$ valence states in these glasses could be obtained from XANES fitting using more standards, if they become available.

\subsubsection{Possible Vanadium Coupling to Chromium}

All three glass series show an increase in $\mathrm{V}^{4+}$ populations after initial exposure to $\mathrm{CO} / \mathrm{CO}_{2}$ bubbling. After this initial reduction, some of the glass samples exposed to longer bubbling periods became less reduced, even to the level of the parent glass (Figures 3.4 - 3.6). The most clear example of this behavior can be seen for the DWV-G-123B series (Figure 3.6), where the glass exposed to 60 minutes of bubbling has the most reduced vanadium valence distribution (near $33 \% \mathrm{~V}^{4+}$ ) of all glasses measured. As the bubbling time increases with additional one or two 30 minute increments, the reduced $\mathrm{Cr}$ species content continues to increase, while the reduced $\mathrm{V}$ species content drops to the level of the parent glass. As more 30 minute bubbling increments are added, the vanadium in the Q10-G-136D and Z10-G-60C glasses becomes slightly more reduced, while chromium continues to be reduced at a slower rate than before (Figures 3.3 - 3.6). These trends may also be present to a certain extent for the DWV-G-123B series (Figure 3.6), except that the Cr valence cannot be completely quantified by XANES fitting, as stated above.

\subsubsection{EXAFS Observations}

EXAFS analyses of the data have also been completed, including fitting the data to quantitatively determine average structural parameters for $\mathrm{V}$ and $\mathrm{Cr}$ environments in these samples. Qualitative comparisons can be made among V EXAFS data for the $\mathrm{V}^{5+}, \mathrm{V}^{4+}$, and $\mathrm{V}^{3+}$ standards and all glasses measured, as well as among Cr EXAFS data for the $\mathrm{Cr}^{6+}$ and $\mathrm{Cr}^{3+}$ standards and three glasses (see figures 3.7 and 3.8 for vanadium and chromium data, respectively).

\section{Vanadium EXAFS}

The V EXAFS for the standards vanadinite, cavansite, and roscoelite are similar to the data presented earlier [3-54]. EXAFS for the glasses basically follow the trends observed for the $\mathrm{V}$ XANES analyses above, where the $\mathrm{k}^{2} \chi(\mathrm{k})$ data and corresponding RDFs for all glasses are similar to that for vanadinite, which indicates that $\mathrm{V}$ is mostly within $\mathrm{VO}_{4}$ tetrahedra in all glasses, as seen 
The Catholic University of America Vitreous State Laboratory
Crystal Settling, Redox, and Properties of ORP HLW \& LAW Glasses Final Report, VSL-09R1510-1, Rev. 0

earlier for borosilicate glasses [3-54]. The largest difference is observed for DWVG123BRE2 glass (60 minute $\mathrm{CO} / \mathrm{CO}_{2}$ bubbling), where the EXAFS amplitudes are dampened compared with the other glasses measured. This difference is likely due to the mixed vanadium sites where $66 \%$ out of all vanadium in the glass is in $\mathrm{V}^{5+} \mathrm{O}_{4}$ environments and $34 \%$ out of all vanadium in the glass is in $\mathrm{V}^{4+} \mathrm{O}_{5}$ environments, as determined from XANES analysis, where this glass has the largest $\mathrm{V}^{4+} \mathrm{O}_{5}$ population of any glass studied here. The $\mathrm{k}^{2} \chi(\mathrm{k})$ data for vanadinite $\left(\mathrm{V}^{5+} \mathrm{O}_{4}\right)$ and cavansite $\left(\mathrm{V}^{4+} \mathrm{O}_{5}\right)$ have oscillations that are out-of-phase with respect to each other. Therefore, one would expect to see dampening of EXAFS amplitudes for a glass containing substantial amounts of $\mathrm{V}^{4+} \mathrm{O}_{5}$ and $\mathrm{V}^{5+} \mathrm{O}_{4}$ sites [3-54]; this dampening is seen in the nearest-neighbor RDF peak for DWVG123BRE2 glass when compared to RDFs for the other glasses studied (Figure 3.7). Other subtle trends, such as different nearest-neighbor RDF peak widths are seen among the different glass series.

\section{Chromium EXAFS}

The Cr EXAFS for the standards crocoite $\left(\mathrm{Cr}^{6+} \mathrm{O}_{4}\right)$ and uvarovite $\left(\mathrm{Cr}^{3+} \mathrm{O}_{6}\right)$ also have oscillations that are out-of-phase with respect to each other. The RDFs of these standards show a shift of the nearest-neighbor peak that reflects the different average $\mathrm{Cr}-\mathrm{O}$ nearest-neighbor distances in these structures [3-60, 3-61] (Figure 3.8).

Cr EXAFS were measured for the Z10-G-60C parent glass, the reduced Z10G60CRE6 glass (180 minutes of $\mathrm{CO} / \mathrm{CO}_{2}$ bubbling), as well as the Q10-G-136D parent glass. Similar to the XANES data, substantial differences are observed in the EXAFS of these three glasses. According to $\mathrm{Cr}$ XANES analyses, Z10-G-60C glass contains the most oxidized $\mathrm{Cr}$ distribution of all glasses investigated; and, correspondingly, the partial RDF is most similar to that for crocoite (Figure 3.8), indicating $\mathrm{Cr}^{6+} \mathrm{O}_{4}$ tetrahedra in this glass. The $\mathrm{k}^{2} \chi(\mathrm{k})$ data for Z10G60CRE6 glass show more EXAFS oscillations that are dampened compared with the parent glass. The partial RDF has nearestneighbor peaks near 1.2 and $1.65 \AA$ that appear to correspond to the $\mathrm{CrO}_{4}$ tetrahedral nearestneighbor RDF peak for crocoite (near $1.2 \AA$ ) and probably reduced $\mathrm{Cr}$ species that may be more reduced than $\mathrm{Cr}^{3+}$ in uvarovite, which has a $1.45 \AA$ nearest-neighbor peak; EXAFS for this glass indicate a mixture of $\mathrm{Cr}$ sites, with the minority being $\mathrm{Cr}$ tetrahedra. The mixed site finding from EXAFS for Z10G60CRE6 glass is consistent with the Cr XANES fitting results, where the $\mathrm{Cr}$ distribution is near $33 \% \mathrm{Cr}^{6+} \mathrm{O}_{4}+67 \% \mathrm{Cr}^{3+} \mathrm{O}_{6}$. The nearest-neighbor RDF peak may indicate longer Cr-O distances in Z10G60CRE6 glass than the $1.98 \AA \mathrm{Cr}-\mathrm{O}$ distances in uvarovite; such a finding may indicate $\mathrm{Cr}^{2+}$ species in this glass, because 2.00 to $2.11 \AA \mathrm{Cr}-\mathrm{O}$ distances are found in some $\mathrm{Cr}^{2+}$-silicate structures [3-65, 3-66]. The partial RDF for Q10-G-136D parent glass is similar to that for Z10-G-60C glass, except for the dampened amplitude of the nearest-neighbor peak. This probably indicates a mixture of $\mathrm{Cr}^{6+} \mathrm{O}_{4}$ and $\mathrm{Cr}^{3+} \mathrm{O}_{6}$ sites in this glass, where $\mathrm{Cr}$ tetrahedral sites are in the majority, consistent with Cr XANES analysis (Figure 3.5). 
The Catholic University of America Vitreous State Laboratory
Crystal Settling, Redox, and Properties of ORP HLW \& LAW Glasses

Final Report, VSL-09R1510-1, Rev. 0

\subsection{Summary and Conclusions}

Redox equilibria of vanadium, tin, chromium and iron in LAW glasses were studied. Iron and tin redox states in the glass were studied by Mössbauer spectroscopy. Valence states of vanadium and chromium in the glasses were studied by XANES and EXAFS. The principal results and conclusions are summarized below.

- The tin redox couple, $\mathrm{Sn}^{2+} / \mathrm{Sn}^{4+}$, is reported to be among the hardest to reduce [3-34] and tin is expected to be present in the glass mostly as $\mathrm{Sn}^{4+}$. Since a tin Mössbauer source was not available at the VSL, one glass sample was analyzed at the Science Engineering and Education Company of Minneapolis, MN. For this measurement, the tin-containing glass sample R10G155BRE8 that is expected to have the highest concentration of reduced species was selected. This sample was subjected to 510 minutes of $\mathrm{CO} / \mathrm{CO}_{2}$ gas mixture bubbling and the measured iron redox ratio $\left(\mathrm{Fe}^{2+} / \mathrm{Fe}_{\text {tot }}\right)$ was 0.68 . Analysis of the tin Mössbauer spectrum showed the sample to contain about $3 \%$ of tin in the $\mathrm{Sn}^{2+}$ state with the remaining $97 \%$ as $\mathrm{Sn}^{4+}$. During LAW processing, the conditions are expected to be much more oxidizing than in the preparation of the above sample and therefore almost all of the tin is expected to be present in the oxidized $\mathrm{Sn}^{4+}$ state.

- Iron redox has been used as a redox probe and a potential redox buffer in industrial glasses and in many radioactive waste glass formulations. In the current work, the redox state of iron in five glass samples was measured by Mössbauer spectroscopy, despite the low iron concentration in these glasses $\left(\sim 1 \mathrm{wt} \% \mathrm{Fe}_{2} \mathrm{O}_{3}\right)$. However, at these low concentrations Mössbauer spectroscopy can no longer be considered a routine technique for determination of redox state of iron in glass because long count times (weeks) are required to obtain spectra that can be analyzed. Even at very long count times, the quality of the Mössbauer spectra is not very good because of the noise and distortion from the background that reduces the precision and accuracy of the analysis.

- The vanadium $\left(\mathrm{V}^{4+} / \mathrm{V}^{5+}\right)$ redox couple is expected to behave in a manner similar to the iron $\left(\mathrm{Fe}^{2+} / \mathrm{Fe}^{3+}\right)$ redox couple, as can be seen in Figure 3.2 [3-34]. During the present work, discussed above, only a small number of iron redox measurements were possible by Mössbauer spectroscopy, allowing only limited comparison between the redox behavior of iron and vanadium. In contrast, XANES and EXAFS spectroscopic studies of vanadium provided a much more thorough analysis of its speciation in the three ORP LAW glasses tested. The highest reduction of vanadium was observed in glass sample DWVG123BRE2 (from DWV-G-123B series of glasses) with $0.34 \mathrm{~V}^{4+} / \mathrm{V}_{\text {tot }}$ after 60 minutes of exposure to $\mathrm{CO} / \mathrm{CO}_{2}$ bubbling. This formulation has a target vanadium $\left(\right.$ as $\left.\mathrm{V}_{2} \mathrm{O}_{5}\right)$ concentration of $1.23 \mathrm{wt} \%, 1.14 \mathrm{wt} \%$ iron $\left(\right.$ as $\left.\mathrm{Fe}_{2} \mathrm{O}_{3}\right)$, and a very low target concentration of chromium $(0.11$ $\mathrm{wt} \% \mathrm{Cr}_{2} \mathrm{O}_{3}$ ), which is contributed entirely by the waste. On the other hand, less than $15 \%$ of vanadium was present as $\mathrm{V}^{4+}$ in samples of glasses Q10-G-136D and Z10-G-60C subjected to $\mathrm{CO} / \mathrm{CO}_{2}$ bubbling for periods ranging from 30 to 390 minutes. The target composition of glass Q10-G-136D includes $1.75 \mathrm{wt} \% \mathrm{~V}_{2} \mathrm{O}_{5}, 0.24 \mathrm{wt} \% \mathrm{Fe}_{2} \mathrm{O}_{3}$, and $0.5 \mathrm{wt} \% \mathrm{Cr}_{2} \mathrm{O}_{3}$. Glass Z10-G-60C 
The Catholic University of America Vitreous State Laboratory
Crystal Settling, Redox, and Properties of ORP HLW \& LAW Glasses Final Report, VSL-09R1510-1, Rev. 0

has target concentrations of $1.97 \mathrm{wt} \% \mathrm{~V}_{2} \mathrm{O}_{5}, 0.3 \mathrm{wt} \% \mathrm{Fe}_{2} \mathrm{O}_{3}$, and $0.5 \mathrm{wt} \% \mathrm{Cr}_{2} \mathrm{O}_{3}$. Glasses DWV-G-123B, Q10-G-136D, and Z10-G-60C have target $\mathrm{Na}_{2} \mathrm{O}$ concentrations of $9.96 \mathrm{wt} \%$, $16.0 \mathrm{wt} \%$, and $22.0 \mathrm{wt} \%$, respectively. From a review of the glass compositions, it is not clear whether the difference in vanadium redox behavior in glass DWV-G-123B as compared to the other two glasses is due to the mutual interaction of the various redox couples or due to the change in glass basicity. Note that the change in valence distributions is clearly larger than the uncertainty associated with the fitting of XANES spectrum in glass DWV-G-123B. Furthermore, the maximum $\mathrm{V}^{4+}$ of $34 \%$ observed after 60 minutes of exposure to $\mathrm{CO} / \mathrm{CO}_{2}$ bubbling is consistent with the results of redox measurement of iron in this sample $\left(47 \% \mathrm{Fe}^{2+}\right)$ as compared to the sample exposed to $\mathrm{CO} / \mathrm{CO}_{2}$ bubbling for 390 minutes $\left(31 \% \mathrm{Fe}^{2+}\right)$. The origin of this behavior remains unclear but it could be related to interactions between the redox couples, including the possibility of further reduction of chromium to $\mathrm{Cr}^{2+}$. The steady ingrowth of reduced chromium compared to the early in-growth and subsequent decline of reduced vanadium is suggestive of a reaction between these species that consumes the reduced vanadium. Variations in the vanadium redox state in samples subjected to $\mathrm{CO} / \mathrm{CO}_{2}$ bubbling for the other two glasses (Q10-G-136D and Z10-G-60C) were within or close to the fitting uncertainty. In these samples, the fraction of vanadium in the $\mathrm{V}^{4+}$ state seems to increase slightly as $\mathrm{CO} / \mathrm{CO}_{2}$ bubbling time increase, but generally remains around $0.1 \mathrm{~V}^{4+} / \mathrm{V}_{\text {tot }}$. This is indicative of the buffering of this redox couple.

- In this study, chromium showed the largest variation in the redox state between the untreated parent glasses and the samples exposed to $\mathrm{CO} / \mathrm{CO}_{2}$ bubbling. XANES analysis indicates that glasses collected from the melter all contain some $\mathrm{Cr}^{3+}$, varying from $16 \% \mathrm{Cr}^{3+}$ in Z10-G-60 to $43 \%$ in Q10-G-136 and 85\% in DWV-G-123B. The glass DWV-G-123B has a target $\mathrm{Cr}_{2} \mathrm{O}_{3}$ concentration of $0.11 \mathrm{wt} \%$, and the other two glasses have target $\mathrm{Cr}_{2} \mathrm{O}_{3}$ concentration of $0.5 \mathrm{wt} \%$. Samples of Z10-G-60C glass exposed to $\mathrm{CO} / \mathrm{CO}_{2}$ bubbling showed increases in the amount of chromium as $\mathrm{Cr}^{3+}$ from $16 \%$ in the parent glass to as high as $68 \%$ in a sample treated for 210 minutes. Similarly, samples of Q10-G-136D also showed increases in $\mathrm{Cr}^{3+}$ content, increasing from $34 \%$ of chromium in the parent glass to $95 \%$ in a sample exposed to $\mathrm{CO} / \mathrm{CO}_{2}$ bubbling for 390 minutes. The glass with the low $\mathrm{Cr}_{2} \mathrm{O}_{3}$ concentration of $0.11 \mathrm{wt} \%$, DWV-G-123B, showed reduction of all the chromium to the $\mathrm{Cr}^{3+}$ state in all of the samples exposed to $\mathrm{CO} / \mathrm{CO}_{2}$ bubbling. There is indication of further reduction of the chromium to $\mathrm{Cr}^{2+}$, but this could not be confirmed due to lack of crystalline standards containing chromium in the $\mathrm{Cr}^{2+}$ state. It has been reported that the $\mathrm{Cr}^{3+} / \mathrm{Cr}^{6+}$ redox couple can cause foaming in ORP LAW glasses [3-67 - 3-69]. This concern, combined with the finding that it is easily reduced, should be a consideration when using $\mathrm{Cr}_{2} \mathrm{O}_{3}$ as a glass former additive to minimize corrosion of K-3 refractory in the melter [3-44]. Therefore, addition of $\mathrm{Cr}_{2} \mathrm{O}_{3}$ should be limited to lowsulfate, high-alkali LAW streams, where corrosion of the K-3 refractory is a major waste loading limiting factor in glass formulation. 
The Catholic University of America Vitreous State Laboratory
Crystal Settling, Redox, and Properties of ORP HLW \& LAW Glasses Final Report, VSL-09R1510-1, Rev. 0

\subsection{References}

[3-1] "Melter Tests with LAW Envelope A and C Simulants to Support Enhanced Sulfate Incorporation," K.S. Matlack, S.P. Morgan, and I.L. Pegg, VSL-01R3501-2, Rev. 0, Vitreous State Laboratory, Washington, D.C., 1/26/01.

[3-2] "Melter Tests with LAW Envelope B Simulants to Support Enhanced Sulfate Incorporation," K.S. Matlack, S.P. Morgan, and I.L. Pegg, VSL-00R3501-1, Rev. 0, Vitreous State Laboratory, Washington, D.C., 11/27/00.

[3-3] "Compositional Variation Tests on DuraMelter 100 with LAW Sub-Envelope A1 Feed (LAWA44 Glass) in Support of the LAW Pilot Melter," K.S. Matlack, W. Gong, and I.L. Pegg, VSL-02R62N0-4, Rev. 0, Vitreous State Laboratory, Washington, D.C., 6/18/02.

[3-4] "DuraMelter 100 Sub-Envelope Changeover Testing Using LAW Sub-Envelope A1 and C1 Feeds in Support of the LAW Pilot Melter," K.S. Matlack, W. Gong, and I.L. Pegg, VSL02R62N0-6, Rev. 0, Vitreous State Laboratory, Washington, D.C., 9/9/03.

[3-5] "Compositional Variation Tests on DuraMelter 100 with LAW Sub-Envelope A2 Feed (LAWA88) Glass in Support of the LAW Pilot Melter," K. S. Matlack, W. Gong and I.L. Pegg, VSL-02R62N0-3, Rev. 0, Vitreous State Laboratory, Washington, D.C., 11/1/02.

[3-6] "DuraMelter 100 Sub-Envelope Changeover Testing Using LAW Sub-Envelope A2 and B1 Feeds in Support of the LAW Pilot Melter," K.S. Matlack, W. Gong, and I.L. Pegg, VSL03R3410-1, Rev. 0, Vitreous State Laboratory, Washington, D.C., 8/22/03.

[3-7] "Compositional Variation Tests on DuraMelter 100 with LAW Sub-Envelope A3 Feed in Support of the LAW Pilot Melter," K.S. Matlack, W. Gong, and I.L. Pegg, VSL-01R62N0-1, Rev. 1, Vitreous State Laboratory, Washington, D.C., 7/15/02.

[3-8] "DuraMelter 100 Sub-Envelope Changeover Testing Using LAW Sub-Envelope A3 and C2 Feeds in Support of the LAW Pilot Melter," K.S. Matlack, W. Gong, and I.L. Pegg, VSL03R3410-3, Rev. 0, Vitreous State Laboratory, Washington, D.C., 10/17/03.

[3-9] "Compositional Variation Tests on DuraMelter 100 with LAW Sub-Envelope B1 Feed in Support of the LAW Pilot Melter," K.S. Matlack, W. Gong, and I.L. Pegg, VSL-02R62N0-5, Rev. 0, Vitreous State Laboratory, Washington, D.C., 5/8/03.

[3-10] "Compositional Variation Tests on DuraMelter 100 with LAW Sub-Envelope B2 Feed in Support of the LAW Pilot Melter," K.S. Matlack and I.L. Pegg, VSL-03R3410-2, Rev. 0, Vitreous State Laboratory, Washington, D.C., 10/20/03. 
The Catholic University of America Vitreous State Laboratory
Crystal Settling, Redox, and Properties of ORP HLW \& LAW Glasses Final Report, VSL-09R1510-1, Rev. 0

[3-11] "Compositional Variation Tests on DuraMelter 100 with LAW Sub-Envelope C1 Feed (LAWC22 Glass) in Support of the LAW Pilot Melter," K.S. Matlack, W. Gong, and I.L. Pegg, VSL-02R62N0-2, Rev. 1, Vitreous State Laboratory, Washington, D.C., 9/23/02.

[3-12] "Compositional Variation Tests on DuraMelter 100 with LAW Sub-Envelope C2 Feed in Support of the LAW Pilot Melter," K.S. Matlack, W. Gong, R. Callow, and I.L. Pegg, VSL04R4410-1, Rev. 0, Vitreous State Laboratory, Washington, D.C., 6/17/04.

[3-13] "RPP-WTP Pilot Melter Envelope B Throughput Test Results Report," GTS Duratek, Inc., TRR-PLT-57, 10/13/00.

[3-14] "RPP-WTP Pilot Melter Envelope A and C Throughput Test Results Report," GTS Duratek, Inc., TRR-PLT-54, 10/13/00.

[3-15] “RPP-WTP Pilot Melter Sub-Envelope A1 Variation Test Results Report," TRR-PLT-071, Rev. 0, 4/28/03.

[3-16] "RPP-WTP Pilot Melter Sub-Envelope C1-A1 Changeover Test Results Report," TRR-PLT035, Rev. 0, 9/29/03.

[3-17] “RPP-WTP Pilot Melter Sub-Envelope A2 Variation Test Results Report," TRR-PLT-070, Rev. 0, 10/4/02.

[3-18] "RPP-WTP Pilot Melter Sub-Envelope A2-B1 Changeover Test Results Report," TRR-PLT078, Rev. 0, 11/3/03.

[3-19] “RPP-WTP Pilot Melter Sub-Envelope A3 Variation Test Results Report,” TRR-PLT-060, Rev. 2, 11/19/02.

[3-20] "RPP-WTP Pilot Melter Sub-Envelope C2-A3 Changeover Test Results Report," TRR-PLT079, Rev. 0, 11/11/03.

[3-21] "RPP-WTP Pilot Melter Sub-Envelope B1 Variation Test Results Report," TRR-PLT-074, Rev. 0, 8/26/03.

[3-22] “RPP-WTP Pilot Melter Sub-Envelope B2 Variation Test Results Report,” TRR-PLT-073, Rev. 0, 10/27/03.

[3-23] "RPP-WTP Pilot Melter Sub-Envelope C1 Variation Test Results Report," TRR-PLT-069, Rev. 2, 2/6/03.

[3-24] “RPP-WTP Pilot Melter Sub-Envelope C2 Variation Test Results Report,” TRR-PLT-072, Rev. 1, 3/12/03. 
The Catholic University of America Vitreous State Laboratory
Crystal Settling, Redox, and Properties of ORP HLW \& LAW Glasses Final Report, VSL-09R1510-1, Rev. 0

[3-25] "Integrated Off-Gas System Tests on the DM1200 Melter with RPP-WTP LAW SubEnvelope A1 Simulants," K.S. Matlack, W. Gong, T. Bardakci, N. D’Angelo, and I.L. Pegg, VSL-02R8800-2, Rev. 0, Vitreous State Laboratory, Washington, D.C., 9/03/02.

[3-26] "Integrated Off-Gas System Tests on the DM1200 Melter with RPP-WTP LAW SubEnvelope B1 Simulants," K.S. Matlack, W. Gong, T. Bardakci, N. D’Angelo, and I.L. Pegg, VSL-03R3851-1, Rev. 0, 5/02/03.

[3-27] "Integrated Off-Gas System Tests on the DM1200 Melter with RPP-WTP LAW SubEnvelope C1 Simulants," K.S. Matlack, W. Gong, T. Bardakci, N. D’Angelo, and I.L. Pegg, VSL-02R8800-1, Rev. 0, Vitreous State Laboratory, Washington, D.C., 7/25/02.

[3-28] "Comparison of LAW Simulant, Actual Waste, and Melter Glasses," I.S. Muller, I. Joseph, and I.L. Pegg, VSL-05R5460-1, Rev. 0, Vitreous State Laboratory, The Catholic University of America, Washington, D.C., 07/18/05

[3-29] "An electromotive force series in a borosilicate glass-forming melt," H.D. Schreiber, G.B. Balazs, B.E. Carpenter, J.E. Kirkley, L.M. Minnix, P.L. Jamison, Comm. Amer. Ceram. Soc. 67 (6), C106-109 (1984).

[3-30] "Redox Equilibria and Kinetics of Iron in a Borosilicate Glass-Forming Melt ," H.D. Schreiber, S.J. Kozak, R.C. Merkel, G.B. Balazs and P.W. Jones Jr., J. Non-Crystalline Solids (84) 186-195 (1986).

[3-31] "An electrochemical series of redox couples in silicate melts: a review and applications to geochemistry,” H.D. Schreiber, J. Geophys. Res. 92:9225-9232 (1987).

[3-32] „Vanadium as an oxygen geobarometer in basaltic magmas: The further development of a geochemical electromotive force series," H.D. Schreiber, G.B. Balazs, Lunar Planet Sci. XIII, 692-693 (1982).

[3-33] "Compositional dependence of redox equilibria in sodium-silicate glasses ," H.D. Schreiber, B.K. Kochaniwski, C.W. Schreiber, A.B. Morgan, M.T. Coolbaugh, T.G. Dunlap, J. NonCrystalline Solids, 177, 340-346 (1994).

[3-34] "A comprehensive electromotive force series of redox couples in soda-lime-silicate glass ," H.D. Schreiber, N.R. Wilk, C.W. Schreiber, J. Non-Crystalline Solids 253, 68-75 (1999).

[3-35] „Redox Chemistry in Candidate Glasses for Nuclear Waste Immobilization,” H.D. Schreiber and A. L. Hockman, J. Am. Ceram. Soc., 70 (8) 591-594 (1987).

[3-36] "Glass Formulation And Testing With RPP-WTP LAW Simulants," I.S. Muller, A.C. Buechele, and I.L. Pegg, Final Report, VSL-01R3560-2, Vitreous State Laboratory, The Catholic University of America, Washington, DC, 2/23/01. 
The Catholic University of America Vitreous State Laboratory
Crystal Settling, Redox, and Properties of ORP HLW \& LAW Glasses Final Report, VSL-09R1510-1, Rev. 0

[3-37] "Composition Effects on the Vapor Hydration of Waste Glasses," A.C. Buechele, F. Lofaj, I.S. Muller, C.T. Mooers, and I.L. Pegg, Ceramic Transactions, Vol. 155, p. 289, (2004).

[3-38] "Vapor Hydration Testing of Tin-Containing Glasses", A.C. Buechele, C.T. Mooers, I.S. Muller, H. Gan and I.L. Pegg, 106th Annual Meeting of The American Ceramic Society, April 4, Indianapolis, 2004.

[3-39] "Tin as an Additive to Improve the VHT performance of High-Alkali Waste Glasses", A.C. Buechele, C.T. Mooers, I.S. Muller, H. Gan, and I.L. Pegg, Materials Science and Technologies 2006, Cincinnati, OH, Oct. 15-18, 2006.

[3-40] "Formulation, Testing and Structural Characterization of High-Zirconium High-Level Waste Glasses," D.A. McKeown, I.S. Muller, A.C. Buechele, I.L. Pegg, C.A. Kendziora, and C.R. Scales, Mat. Res. Soc. Symp. Proc., 556, 305 (1999).

[3-41] "X-Ray Absorption Studies of the Local Environment of Zr in High-Zirconia Borosilicate Glasses," D.A. McKeown, I.S. Muller, A.C. Buechele, and I.L. Pegg, J. Non- Crystalline Solids, 258, (1999).

[3-42] "Structural Characterization of High-Zirconia Borosilicate Glasses Using Raman Spectroscopy," D.A. McKeown, I.S. Muller, A.C. Buechele, I.L. Pegg, and C. A. Kendziora, J. Non-Crystalline Solids, 262, p. 126 (2000).

[3-43] "Tin Valence and Local Environments in Silicate Glasses as Determined from X-ray Absorption Spectroscopy", D.A. McKeown, A.C. Buechele, H.Gan, and I.L. Pegg, J. NonCrystalline Solids, 354, 3142 (2008).

[3-44] “Enhanced LAW Glass Formulation Testing,” K.S. Matlack, I. Joseph, W. Gong, I.S. Muller, and I.L. Pegg, Final Report, VSL-07R1130-1, Rev. 0, Vitreous State Laboratory, The Catholic University of America, Washington, DC, 10/05/07.

[3-45] "Square-wave voltametry and Mossbauer spectroscopy in tin-doped soda silicate and soda-lime-silicate glasses,” D. Benne, C. Rűssel, O. Lehmann, M. Menzel, D. Niermeir, and K.D. Becker, J. Non- Crystalline Solids, 318, p.202-212 (1999).

[3-46] "Redox behavior of $\mathrm{Sn}^{4+} / \mathrm{Sn}^{2+}$ in alkali free aluminosilicates glasses and melts," D. Ehrt, Phys. and Chem. of Glasses: Eur. J. of Glass Sci. and Tech. Part B, 49, (2008).

[3-47] "Redox Equilibria and Corrosion in Molten Silicates: Relationship with Electrode Potentials in Aqueous Solution,” J.A. Duffy and F. G. K. Baucke, J. Phys. Chem., 99 (22), 9189-9193 (1995). 
The Catholic University of America Vitreous State Laboratory
Crystal Settling, Redox, and Properties of ORP HLW \& LAW Glasses Final Report, VSL-09R1510-1, Rev. 0

[3-48] "Glasses for Immobilisation of Sulfate-Containing Radioactive Wastes", S.V. Stefanovskii and F.A. Lifanov, Radiokhimiya, 31 (6) 746-751 (1989).

[3-49] "Sulfur Incorporation in Waste Glass Melts of Various Compositions," W.K. Kot, H. Gan, and I.L. Pegg, Ceramic Transactions, Vol. 107, pp. 441, Eds. G.T. Chandler and X. Feng, American Ceramic Society, (2000).

[3-50] "Glass Formulation Testing to Increase Sulfate Incorporation," K. S. Matlack, M. Chaudhuri, H. Gan, I.S. Muller, W. Gong, and I.L. Pegg, Final Report, VSL-04R4960-1, Rev. 0, Vitreous State Laboratory, The Catholic University of America, Washington, DC, 2/28/05.

[3-51] "Glass Formulation Testing to Increase Sulfate Volatilization from Melter," K.S. Matlack, W. Gong, and I.L. Pegg, Final Report, VSL-04R4970-1, Rev. 0, Vitreous State Laboratory, The Catholic University of America, Washington, DC, 2/24/05.

[3-52] "LAW Envelope A and B Glass Formulation Testing to Increase Waste Loading," K.S. Matlack, H. Gan, I.S. Muller, I. Joseph, and I.L. Pegg, Final Report, VSL-06R6900-1, Rev. 0, Vitreous State Laboratory, The Catholic University of America, Washington, DC, 3/23/06.

[3-53] "LAW Envelope C Glass Formulation Testing to Increase Waste Loading," K.S. Matlack, W. Gong, I.S. Muller, I. Joseph, and I.L. Pegg, Final Report, VSL-05R5900-1, Rev. 0, Vitreous State Laboratory, The Catholic University of America, Washington, DC, 1/27/06.

[3-54] "X-ray Absorption Studies of Vanadium Valence and Local Environment in Borosilicate Waste Glasses Using Vanadium Sulfide, Silicate, and Oxide Standards", D.A. McKeown, I.S. Muller, K.S. Matlack, and I.L. Pegg, J. Non-Crystalline Solids, 298, 160-175 (2002).

[3-55] "X-ray Absorption Studies of Vanadium Valence and Local Environment in Borosilicate Waste Glasses,” D.A. McKeown, I.S. Muller, K.S. Matlack, and I.L. Pegg, Scientific Basis for Nuclear Waste Management XXV, Materials Research Society, 713, 547-554, (2002).

[3-56] "Silicon photodiode detector for fluorescence EXAFS," C.E. Bouldin, R.A. Forman, and M.I. Bell, Rev. Sci. Instruments 581891 (1987).

[3-57] "Crystal structure refinements of vanadinite and pyromorphite," Y. Dai and J. Hugnes, Canad. Min., 27, 189 (1989).

[3-58] "The crystal structures of cavansite and pentagonite," H.T. Evans, Am. Min., 58, 412 (1973).

[3-59] "Studies in the mica group; x-ray data on roscoelite and barium-muscovite," E.W. Heinrich and A..A. Levinson, Amer. J. Sci., 253, 39 (1955).

[3-60] "A three-dimensional refinement of the structure of crocoite, PbCrO4," S. Quareni and R. De Pieri, Acta Cryst., 19, 287 (1965). 
The Catholic University of America Vitreous State Laboratory
Crystal Settling, Redox, and Properties of ORP HLW \& LAW Glasses Final Report, VSL-09R1510-1, Rev. 0

[3-61] "The crystal chemistry of the silicate garnets," G.A. Novak and G.V. GibbsAm. Min., 56, 791 (1971).

[3-62] "IFEFFIT: interactive XAFS analysis and FEFF fitting," M. Newville, J. Synchrotron Rad., 8, pp 322 (2001). Further information about IFETTIT can be obtained at: http://cars9.uchicago.edu/ifeffit/.

[3-63] D.E. Sayers and B.A. Bunker in: X-ray Absorption Principles, Applications, Techniques of EXAFS, SEXAFS, and XANES, ed. D.C. Kroningsberger, R. Prins, Wiley ed., New York, Ch. 6, p. 211, (1988).

[3-64] "A XANES determination of the oxidation state of chromium in silicate glasses,"A.J. Berry and H. St. C. O’Neill, Am. Min., 89, 790 (2004).

[3-65] "Structure of $\mathrm{Cr}_{2} \mathrm{SiO}_{4}$ and possible metal-metal interactions in crystal and melt," W.A. Dollase, F. Seifert, and H. St. C. O’Neill, Phys. Chem. Min., 21, 104 (1994).

[3-66] “Crystal structure and optical spectroscopy (300 to $2200 \mathrm{~nm}$ ) of CaCrSi${ }_{4} \mathrm{O}_{10}$," H.L. Belsky, G.R. Rossman, C.T. Prewitt, and T. Gasparik, Am. Min., 69, 771 (1984).

[3-67] "Cause of Foaming of Iron-Containing Melts,"A. E. Kuleva, N. A. Pankova, and L. A. Orlova, Glass and Ceramics Vol. 56, Nos. 7-8, 210-215 (1999).

[3-68] "Redox Reaction and Foaming in Nuclear Waste Glass Melting” J.L. Ryan, PNNL-10510, Pacific Northwest Laboratory, Richland, W.A., (1995).

[3-69] "Small Scale Melter Testing of LAW Salt Phase Separation," K.S. Matlack, I.S. Muller, W. Gong, and I.L. Pegg, VSL-07R7480-1, Rev. 0, Vitreous State Laboratory, Washington, D.C., 08/20/07. 
The Catholic University of America Vitreous State Laboratory
Crystal Settling, Redox, and Properties of ORP HLW \& LAW Glasses

Final Report, VSL-09R1510-1, Rev. 0

\section{SECTION 4 \\ HIGH TEMPERATURE PROPERTIES OF SELECTED HLW AND LAW GLASSES AND MELTS}

\subsection{Background and Glass Selection}

Treatment of radioactive waste streams by vitrification involves high-temperature processing in a glass melter to convert them into stable and durable glass for long term storage. A variety of material properties, both as the melt inside the glass melter and as the solid glass below glass transition temperature, are naturally of importance. Properties to assure processability for an acceptable glass formulation, such as, viscosity and electrical conductivity of the melt, are routinely determined experimentally. However, other properties, such as specific heat, density, and thermal conductivity, have been seldom reported, perhaps partly due to the assumption that they are less susceptible to variations with temperature and glass composition, and to a large extent, due to the inherent experimental difficulties in making these high temperature measurements. In particular, these properties are crucial inputs for heat load calculations to assess the impacts of canister filling and cooling. The wide variations in chemical composition of Hanford waste streams have mandated development of waste glasses with rather distinctive chemical compositions [4-1]. This further underscores the need for direct measurement of these key glass properties [4-2]. Despite the importance of these properties, there have been no previous measurements of them for the Hanford Tank Waste Treatment and Immobilization Plant (WTP) High Level Waste (HLW) or Low Activity Waste (LAW) glasses.

Four representative waste glasses, two for HLW and two for LAW, were selected for characterization of their high temperature properties: specific heat, density, thermal diffusivity, and thermal conductivity. As listed in Table 4.1, the HLW glass WTP-C106 was formulated for an ironrich waste stream (from C-106/AY-102) [4-3] and iron oxide was added as glass former in the LAW glass for Envelope A waste, LAWA44 [4-4]. In contrast, much lower iron contents are present in HLW-E-A127 [4-5] and ORPLA20 [4-6], which were formulated to accommodate an Al-rich HLW stream (for HLW-E-A127) and an LAW stream (for ORPLA20), respectively. The glass names (WTP-C106, LAWA44, HLW-E-AL27, and ORPLA20) refer to the nominal compositions; the actual samples used in the present work were taken from continuous melter tests with these nominal compositions. The specific samples from those melter tests are denoted by separate sample names (WTP-C106, 12U-G-86A, BLM-G-139A, and Y10-G-146B), the analyzed compositions of which are provided in Table 4.1.

High temperature as used in this report refers to temperatures at which a glass melter processes the waste and the range within which an immobilized waste glass melt cools and solidifies in a storage canister. Thus, the temperatures of interest are from $1150^{\circ} \mathrm{C}$ down to below glass transition (typically $\sim 500^{\circ} \mathrm{C}$ ). The details of each of the experimental methods are described in the following sections, followed by presentation and discussion of the experimentally determined property data. 
The Catholic University of America Vitreous State Laboratory
Crystal Settling, Redox, and Properties of ORP HLW \& LAW Glasses

Final Report, VSL-09R1510-1, Rev. 0

\subsection{Experimental Methods}

\subsubsection{Specific Heat}

The specific heat of glass melts and solid glass samples was measured by Differential Scanning Calorimetry (DSC) following VSL technical procedure TPI-DSC [4-7]. Under a controlled environment and constant heating rate, the heat flux between the reference and the sample were continuously measured by two highly sensitive thermocouples. After proper baseline correction, the specific heat as a function of temperature can be calculated from the observed heat flux.

A Setaram ${ }^{\mathrm{TM}}$ MHTC96 with TG-DSC module was used for measurement of specific heat of glass and glass melt samples. The system was calibrated using National Institute of Standards and Technology (NIST)-traceable standards under identical conditions as used for the samples and over the same temperature range for the measurement of specific heat of melt and glass samples. All measurements, the blank, NIST standard, and glass samples, were made at heating (or cooling) rate of $5^{\circ} \mathrm{C} /$ minute in an ambient environment controlled by regulated air flow through the sample chamber. For each measurement, about $500 \mathrm{mg}$ of sample was loaded into a Pt sample cup and melted in a box furnace at $1150^{\circ} \mathrm{C}$ for several hours before the DSC measurements. Data from three consecutive heating and cooling cycles were collected, calculated, and averaged for the final presented data; any obvious outlying points in the raw data were removed prior to averaging. The low temperature end (above $300^{\circ} \mathrm{C}$ ) was limited by the temperature control of the calorimeter and the high temperature end was set to be below $1100^{\circ} \mathrm{C}$ to minimize corrosion problem of the Pt-ware in the DSC module.

For comparison, the specific heat of the four glasses was also collected during cooling and calculated using the same NIST standard in the same cooling condition after baseline correction. However, since the specific heat during heating covers a wider temperature range and are likely more reliable, these data were used for calculation of thermal conductivity in this report.

\subsubsection{Density}

Archimedes' method was used for determination of glass melt density at controlled temperatures [4-8]. In a typical experiment, a bob of known mass and dimension is weighed separately in air and in a glass melt of interest. The ratio of the buoyancy, which accounts for the weight difference measured in air and in the melt, to the volume of the bob is equal to the density of the glass melt.

An analytical balance configured for bottom-hook application was located above a high temperature vertical tube furnace, with adequate thermal insulation in place to protect the balance. A $\mathrm{Pt}-10 \% \mathrm{Rh}$ bob of known volume and mass was suspended from the bottom hook of the balance by a 20 mil diameter $\mathrm{Pt}-10 \% \mathrm{Rh}$ wire and immersed in the glass melt. The temperature of the sample was determined by a thermocouple calibrated following VSL procedure [4-9]. The condition of the balance was checked periodically by trained professionals following VSL procedure [4-10], and the 
The Catholic University of America Vitreous State Laboratory
Crystal Settling, Redox, and Properties of ORP HLW \& LAW Glasses Final Report, VSL-09R1510-1, Rev. 0

density calculation was calibrated periodically by measuring the density of molten reagent grade $\mathrm{NaCl}[4-11,4-12]$.

About 100 grams of the glass melt was contained in a Pt-10\%Rh cylindrical crucible placed in the hot zone of the tube furnace. For buoyancy measurement, the bob was fully immersed in the glass melt while being suspended from the analytical balance. A second bob of different volume and mass was also used for confirmation. The experimental temperature range at which density was measured was largely determined by the condition of the glass melt. For the four glass samples studied in the present work, the low temperature end was limited to $700^{\circ} \mathrm{C}$ by the viscosity and the tendency for crystallization in some samples.

For solid glass samples, the density was measured according to a VSL technical procedure TPI-DENS (Rev \#3) adapted from ASTM D854-00 using the Pycnometry method [4-13].

\subsubsection{Thermal Diffusivity}

A modified Ångström method was used for measurement of the thermal diffusivity of glass melts at high temperature. The method can be applied to a material in cylindrical geometry, the surface of which is subjected to periodic temperature variations around a given mean temperature, at a given amplitude and period, created by a concentrically aligned cylindrical heat source. The propagation of heat waves is monitored radially at two locations. The thermal diffusivity of the substance at the given mean temperature can be calculated from the observed phase lags of the temperature waves [4-14].

Experimental work and data reduction were conducted following VSL technical procedure TPI-TDG [4-14]. Briefly, glass was loaded into a long, cylindrical crucible which was placed in the center of the heat source. Two S-type thermocouples were used to measure temperature, with one at the center and the other near the inner surface of the cylinder. The sinusoidal temperature changes of the furnace and the temperatures measured by the two monitoring thermocouples were recorded via an A/D converter and stored digitally in a PC for subsequent data analysis. The method of calculation of thermal diffusivity from the experimentally measured temperature wave at two locations is described in detail in a VSL procedure [4-14].

Cylindrical crucibles $\sim 8$ inch tall and 3.1 inch internal diameter were fabricated from seamless Inconel 601 tube. When it was fully loaded with glass, the ratio of the immersion depth $(\sim 3$ inch) of the thermocouples to the distance between the two thermocouples ( $\sim 1$ inch) was almost 3 , a value considered sufficient to be able to ignore fringe effects [4-15]. For each of the average temperatures, the heat wave was modulated by $\pm 15^{\circ} \mathrm{C}$ at periods of 30 minutes and 60 minutes. The obtained sinusoidal waves from each of the two monitoring thermocouples were then analyzed by Fast Fourier Transform via LabView (version 7) to determine the phase lag between the two locations separated by a known distance. The thermal diffusivity at the test temperature was calculated on the basis of the phase lag and the distance following the method derived by Van Zee and Babcock [4-16]. 
The Catholic University of America Vitreous State Laboratory
Crystal Settling, Redox, and Properties of ORP HLW \& LAW Glasses

Final Report, VSL-09R1510-1, Rev. 0

\subsection{Specific Heat Data}

Figure 4.1 shows experimentally determined data of the specific heat for the four representative waste glasses and melts. The data are listed at every ten degrees in Table 4-2 for all four glasses up to their respective glass transition temperature. Above the glass transition, the specific heats of the glass melts are listed at every ten degrees up to $1070^{\circ} \mathrm{C}$ for WTP-C 106 , LAWA44, and ORPLA20. However, only two points are listed in Table 4.2 for HLW-E-A127 at 600 and $1070^{\circ} \mathrm{C}$ respectively due to suspected crystallization and subsequent dissolution during the heating ramp (see Figure 4.1, which shows a dip around $800^{\circ} \mathrm{C}$ and a peak around $920^{\circ} \mathrm{C}$ ). The entire data are displayed as observed in Figure 4.1. The reproducibility of the results is expected to be within $15 \%$ [4-7].

In general, the specific heats of these waste glasses, in spite of their significant differences in chemical composition, vary in a similar way with increasing temperature during the heating ramp. Presented in units of joules per degree per gram atom, all four glasses show a well defined glass transition as their specific heat values approach the classical Dulong-Petit $3 \mathrm{R}$ limit $(\sim 24.9 \mathrm{~J} / \mathrm{g}-$ atom $\mathrm{K}$ ). As listed in Table 4.2, the glass transition occurred below $500^{\circ} \mathrm{C}$ for two HLW glasses and above $500^{\circ} \mathrm{C}$ for two LAW glasses. Beyond the glass transition peaks, the specific heats of the glass melts are around 29 to $30 \mathrm{Joule} / \mathrm{g}$-atom $\mathrm{K}$ from 600 to $750^{\circ} \mathrm{C}$. A similar value of specific heat (31 Joule/g-atom $\mathrm{K}$ ) has been reported for the West Valley glass melt WVREF6 at $600^{\circ} \mathrm{C}$ [4-17]. For simpler systems just above their glass transition, a range of 27 to $33 \mathrm{~J} / \mathrm{g}$-atom.K have been reported for melt systems of various chemical compositions $\left(\mathrm{SiO}_{2}\right.$ to more complex $\mathrm{NaAlSi}_{3} \mathrm{O}_{8}, \mathrm{CaAl}_{2} \mathrm{Si}_{2} \mathrm{O}_{8}$, and $\mathrm{CaMgSi}_{2} \mathrm{O}_{6}$ ) [4-18]. At higher temperatures, the specific heats of LAWA44 and ORPLA20 reverse their downward trend slightly at $900^{\circ} \mathrm{C}$ and dip again above $1020^{\circ} \mathrm{C}$; this behavior is even more pronounced for WTP-C106. For HLW-E-A127, there is a dip between 780 and $850^{\circ} \mathrm{C}$, followed by a well defined peak between 850 to $940^{\circ} \mathrm{C}$ (Figure 4.1). It is suspected that these features are likely associated with crystallization and subsequent dissolution during the heating ramp.

The specific heat data for the four glasses collected during the cooling ramps are plotted together with their corresponding heating curves in Figure 4.2. The general pattern is typical for glass systems, showing a moderate level of hysteresis (dependent on heating/cooling rate) while passing through the glass transition temperatures [4-19].

\subsection{Density Data}

Figure 4.3 and Table 4.3 show the experimentally determined density data for the four representative waste glass melts. The density was determined at the nominal melter operating temperature $1150^{\circ} \mathrm{C}$, and at $1100,1000,900$, and $800^{\circ} \mathrm{C}$ for all four glass melts. The lowest temperature was limited by crystallization and the high viscosity of the glass melts. As shown in Figure 4.3, the density of a melt determined by two bobs of rather different volumes agreed well at all temperatures with standard deviations generally less than $0.01 \mathrm{~g} / \mathrm{cm}^{3}$ (Table 4.3 ). A linear relationship is followed approximately with changing temperature (Figure 4.3). The change of melt 
The Catholic University of America Vitreous State Laboratory
Crystal Settling, Redox, and Properties of ORP HLW \& LAW Glasses Final Report, VSL-09R1510-1, Rev. 0

density over a range of $350^{\circ} \mathrm{C}$ is about $2.4-4.6 \%$, which is similar to the temperature dependence of the densities of three waste glass melts reported by Pye et al. (Figure 4.4) [4-8]. The densities of the glass melts investigated in this work vary considerably with glass composition. For example, the melt of ORPLA20 is $3 \%$ and $4.4 \%$ denser than HLW-E-Al27 at $1150^{\circ} \mathrm{C}$ and $800^{\circ} \mathrm{C}$, respectively. Above $900^{\circ} \mathrm{C}$, ORPLA20 with $22.5 \mathrm{wt} \% \mathrm{Na}_{2} \mathrm{O}$ has the highest density and HLW-E-Al27 with $9.6 \mathrm{wt} \% \mathrm{Na}_{2} \mathrm{O}$ has the lowest density for a given temperature; the other two glasses, LAWA44 with $19 \mathrm{wt} \% \mathrm{Na}_{2} \mathrm{O}$ and WTP-C106 with $12.6 \mathrm{wt} \% \mathrm{Na}_{2} \mathrm{O}$ fall in between. It is probably not a coincidence that the gram-atom values of the four glasses listed in Table 4.1 follow the trend of their densities above $900^{\circ} \mathrm{C}$, with ORPLA20 at 21.62 the highest, HLW-E-A127 at 19.28 the lowest, and LAWA44 and WTP-C106 at about 20.8 falling in between.

The density of the glass samples at room temperature are listed in Table 4.1. All four glasses rank in the same order as their corresponding melts at $800^{\circ} \mathrm{C}$. Due to its larger temperature dependence, the density of WTP-C106 glass is the highest among the four at $800^{\circ} \mathrm{C}$ and at room temperature, but it is less dense than the ORPLA20 glass melt between 900 and $1150^{\circ} \mathrm{C}$.

\subsection{Thermal Diffusivity Data}

Figure 4.5 and Table 4.4 show experimentally determined thermal diffusivity data for the four representative waste glass melts. The thermal diffusivity was determined at the nominal melter operating temperature of $1150^{\circ} \mathrm{C}$, and at $1100,1000,900,800$ and $700^{\circ} \mathrm{C}$ for all four glass melts. The low temperature end was limited by crystallization. As shown in Figure 4.5, the thermal diffusivity of a melt determined in two separate experiments using different heat wave periods ( 30 or 60 minute) agreed well at all temperatures with standard deviations generally less than $0.001 \mathrm{~cm}^{2} / \mathrm{s}$, except for a few points above $1100^{\circ} \mathrm{C}$ (Table 4.4). The thermal diffusivity data for three of the melts investigated, ORPLA20, HLW-E-A127, and WTP-C106, display quite large positive dependences on temperature with $50 \%$ to $150 \%$ increases from $1000^{\circ} \mathrm{C}$ to $1150^{\circ} \mathrm{C}$. Derby et al. [4-20] reported similar temperature dependences for three simulated waste glass melts (Figure 4.6). In contrast, the thermal diffusivity of LAWA44 shows a much weaker positive temperature dependence, increasing by only $20 \%$ over the same temperature interval (from 1000 to $1150^{\circ} \mathrm{C}$ ). More importantly, there appears a sudden change in the slopes of thermal diffusivity vs. temperature as the temperature is lowered below $1000^{\circ} \mathrm{C}$ for the two melts that display the steepest temperature dependence at $\mathrm{T}>1000^{\circ} \mathrm{C}$. Below $\sim 1000^{\circ} \mathrm{C}$, the observed thermal diffusivities for HLW-E-27 and WTP-C106 are virtually constant at around $0.004 \mathrm{~cm}^{2} / \mathrm{s}$ from 900 to $700^{\circ} \mathrm{C}$; in contrast, the thermal diffusivities of ORPLA20 and LAWA44 melts continue the same general trend seen at higher temperatures.

The thermal diffusivity of a condensed matter system is typically weakly temperature dependent if the temperature is not too high. The thermal diffusivity of the West Valley WVREF6 glass $/$ melt was reported as a constant equal to $0.009 \mathrm{~cm}^{2} / \mathrm{sec}$ from 0 to $700^{\circ} \mathrm{C}$ [4-17]. Gan et al. reviewed the published thermal diffusivity data of various glass systems [4-21] and noted an almost constant thermal diffusivity for $\mathrm{Na}_{2} \mathrm{O} 2 \mathrm{SiO}_{2}$ up to $1050^{\circ} \mathrm{C}$, a weak temperature dependence for $\mathrm{SiO}_{2}$ from 300 to $800^{\circ} \mathrm{C}$, and an apparently stronger temperature dependence at $\mathrm{T}>800^{\circ} \mathrm{C}$. Interestingly, there were few reports of the thermal diffusivity over the range from 700 to $1150^{\circ} \mathrm{C}$. For a 
The Catholic University of America Vitreous State Laboratory
Crystal Settling, Redox, and Properties of ORP HLW \& LAW Glasses Final Report, VSL-09R1510-1, Rev. 0

blackbody, the peak emissive power shifts toward visible spectral region as temperature increases. Around $1000 \mathrm{~K}$, a large portion of radiation falls outside the region which would be strongly absorbed by silicate based glasses. As a result, probably at around $800-1000^{\circ} \mathrm{C}$, in addition to conduction, radiation starts to contribute significantly to energy transfer. Since the emissive power increases with the fourth power of the absolute temperature, a steeper positive slope would likely ultimately develop at high temperatures, as was observed above $1000^{\circ} \mathrm{C}$ for HLW-E-Al27 and WTPC106.

The visually transparent ORPLA20, which contains virtually no iron or other transition metals contributing significant color (Table 4.1), would conceivably facilitate heat transport via radiation even at lower temperatures. This would explain the steeper slope at lower temperatures for this glass. In contrast, the almost flat thermal diffusivity of LAWA44 seems to suggest a delayed contribution from radiation. It is not clear why the observed thermal diffusivity of LAWA44 is so different from that of the other two iron-bearing melts (HLW-E-Al27 and WTP-C106). The only notable new constituent that is present only in LAWA44 is about $2 \mathrm{wt} \% \mathrm{TiO}_{2}$; however, it is also possible that differences in iron redox may play a role. It would be of interest to investigate this disparity further.

\subsection{Thermal Conductivity Results}

The thermal conductivity $(\kappa, \mathrm{J} / \mathrm{s.cm} . \mathrm{K}$ ) is defined in terms of the heat flux (the rate of heat transfer per unit area) through a material that is subjected to a temperature gradient. For one dimensional situation, Fourier's law is expressed as:

$$
\text { Heat Flux }=-\kappa(\mathrm{d} T / \mathrm{d} x)
$$

where $(\mathrm{d} T / \mathrm{d} x)$ is the temperature gradient. The thermal conductivity can be measured directly by experimental methods or calculated from other material properties using the equation:

$$
\kappa=\alpha \rho C_{p},
$$

where $\alpha$ is the thermal diffusivity $\left(\mathrm{cm}^{2} / \mathrm{s}\right), \rho$ is the density $\left(\mathrm{g} / \mathrm{cm}^{3}\right)$, and $\mathrm{C}_{\mathrm{p}}$ the specific heat at constant pressure (J/g.K). As reported above, data for thermal diffusivity, density, and specific heat have been collected for the four representative waste glasses melts. The thermal conductivity can then be calculated directly from the measured quantities using equation (4-2).

Table 4.5 lists the calculated thermal conductivity of the four glass melts at $800,900,1000$, 1100 , and $1150^{\circ} \mathrm{C}$ from the measured values of specific heat, density, and thermal diffusivity. It should be noted that the specific heat data at $1070^{\circ} \mathrm{C}$ were used for calculations at 1100 and $1150^{\circ} \mathrm{C}$. The overall error of the calculated thermal conductivity was estimated from the error of each of the three property measurement. Using conservative standard deviations of $0.1 \mathrm{~J} / \mathrm{g} . \mathrm{K}$ for specific heat, $0.01 \mathrm{~g} / \mathrm{cm}^{3}$ for density, and $0.001 \mathrm{~cm}^{2} / \mathrm{s}$ for thermal diffusivity, the propagated error for thermal conductivity is estimated to be around $0.006 \mathrm{~J} / \mathrm{s} . \mathrm{cm} . \mathrm{K}$, or roughly $22 \%$. 
The Catholic University of America Vitreous State Laboratory
Crystal Settling, Redox, and Properties of ORP HLW \& LAW Glasses

Final Report, VSL-09R1510-1, Rev. 0

As defined in equation (4-1), thermal conductivity describes the ability of a material to conduct heat under an imposed temperature gradient. Doubling the thermal conductivity implies that twice as much heat is conducted per unit area for a given time and temperature gradient. As shown in Table 4.5 and Figure 4.7, the thermal conductivity varies considerably from sample to sample over the temperature range investigated in this work. At $1000^{\circ} \mathrm{C}$, the thermal conductivity ranges from about $0.003 \mathrm{Cal} / \mathrm{s} . \mathrm{cm} . \mathrm{K}$ to nearly $0.010 \mathrm{Cal} / \mathrm{s} . \mathrm{cm} . \mathrm{K}$, spanning more than a factor of three. Similar to what was observed in the thermal diffusivity data, the thermal conductivity shows a weak dependence on temperature below $900^{\circ} \mathrm{C}$. Above $900^{\circ} \mathrm{C}$, the thermal conductivity increases quickly with temperature, except in the case of LAWA44 (similar to thermal diffusivity); increasing by roughly $200-300 \%$ for HLW-E-Al27 and WTP-C106, and by roughly $150 \%$ for ORPLA20. In contrast, the increase is only about $30 \%$ for LAWA 44 over the same temperature range. Overall, for these glass compositions and temperatures, the behavior of the thermal conductivity is determined largely by that of the thermal diffusivity.

At the low temperature end, the thermal conductivity of the four glass melts ranges from about 0.003 to $0.0085 \mathrm{Cal} / \mathrm{s} . \mathrm{cm} . \mathrm{K}$, in agreement with values typical for liquids at room temperature [4-22]. As the temperature increases, the overall trends in the thermal conductivity of the glass melts (except for LAWA44) are very similar to that of $\mathrm{SiO}_{2}$ glass, as shown Figure 4.8. The thermal conductivity of West Valley WVREF6 of about $0.009 \mathrm{Cal} / \mathrm{s} . \mathrm{cm} . \mathrm{K}$ at $700^{\circ} \mathrm{C}$ is similar to that of ORPLA20 [4-17].

In summary, the thermal conductivity data for the four melts display significant variations with both temperature and glass composition. ORPLA20, HLW-E-A127, and WTP-C106 all show rapid increases with temperature at $\mathrm{T}>900^{\circ} \mathrm{C}$, while LAWA44 shows little change over the same temperature range. The behavior of the thermal conductivity is determined largely by the corresponding thermal diffusivity due to the relatively weak temperature dependence for melt density and specific heat. The approximation of constant thermal diffusivity is not reliable, especially at $\mathrm{T}>900^{\circ} \mathrm{C}$. Furthermore, for the glasses studied in the present work, the thermal conductivity varied by a factor of 2 to 3 between the glasses of different chemical composition. Although the data suggest that light-colored glass melts tend to have higher thermal conductivity, the strong composition dependence could present a challenge in the selection of appropriate bounding data for use in heat load calculation for the WTP. Consequently, further work on the property-composition relationship may be useful.

\subsection{Summary and Conclusions}

New data have been collected to determine the specific heat, density, thermal diffusivity, and thermal conductivity of representative WTP HLW and LAW compositions over a wide range of temperatures. Despite the importance of these properties, these are the first such measurements on WTP glasses. The results illustrate the rather significant dependence of some of these properties on temperature and glass composition. Results for each property are discussed below. 
The Catholic University of America Vitreous State Laboratory
Crystal Settling, Redox, and Properties of ORP HLW \& LAW Glasses

Final Report, VSL-09R1510-1, Rev. 0

The specific heats of the four glass melts are relatively close and follow a similar trend once the data are converted to their gram-atom units (Figure 4.1). Except for HLW-E-Al27, which is suspected to exhibit a contribution due to crystallization and subsequent dissolution during the heating process, the specific heat of the glass melts decreases slightly with increasing temperature above glass transition (from 600 to $900^{\circ} \mathrm{C}$ ). The downward trend is reversed above $900^{\circ} \mathrm{C}$ (Figure 4.1) before reaching a local maximum around $1000^{\circ} \mathrm{C}$, whereupon the declining trend is resumed. This maximum is more pronounced in WTP-C106 (around $1000^{\circ} \mathrm{C}$ ); it is not clear if this also is related to possible crystallization/dissolution effects.

The density of the four tested glass melts differs by as much as $\sim 5 \%$, which is about two times as much as the variation in density of HLW-E-A127 due to temperature change from 800 to $1150^{\circ} \mathrm{C}$. It is interesting to note that the two LAW glass melts with more $\mathrm{Na}_{2} \mathrm{O}$ are considerably denser than the HLW-E-Al27 glass melts between 800 and $1150^{\circ} \mathrm{C}$. HLW-E-Al27 with $\sim 22 \mathrm{wt} \%$ $\mathrm{Al}_{2} \mathrm{O}_{3}$ has the lowest melt density. The melt densities of the four glasses follow the same general trend as their gram-atom values. The densities of the four glass samples at room temperature follow the ranking at higher temperatures with the exception of WTP-C106. The higher glass density of WTP-C106 is the result of the steeper temperature dependence of the density of WTP-C106 melts, as shown in Figure 4.3, coupled with its lower glass transition temperature (Table 4.1).

The thermal diffusivity data for the four glass melts fall into two groups at temperatures below $900^{\circ} \mathrm{C}$ : 1) dark glasses: WTP-C106, HLW-E-A127, and LAWA44; and 2) light glasses: ORPLA20. The thermal diffusivity of the ORPLA20 melt is almost four times that of the three dark glass melts. At temperatures above $900^{\circ} \mathrm{C}$, the thermal diffusivities of two of the melts from the dark glass group, WTP-C106 and HLW-E-Al27, increase much more rapidly with temperature, while LAWA44 maintained its weak temperature dependence up to $1150^{\circ} \mathrm{C}$. Two important observations from thermal diffusivity data are worth noting. Firstly, the approximation of constant thermal diffusivity is not good for these glasses. The thermal diffusivity of ORPLA20 melt increases by $\sim 35 \%$ from 700 to $900^{\circ} \mathrm{C}$ and is almost $300 \%$ higher than that of the other three melts at $700^{\circ} \mathrm{C}$. Clearly, thermal diffusivity depends strongly on both melt composition and temperature. Secondly, the temperature dependence of the thermal diffusivity is not linear. At around $900^{\circ} \mathrm{C}$, two glasses (WTP-C106 and HLW-E-AL27) show a rather sharp increase of thermal diffusivity with temperature suggesting the onset of a rapidly increasing contribution to the heat transfer due to radiation. It appears that radiation becomes a significant part of heat transport at a lower temperature for the light colored melt, whereas it become significant at about 900 to $1000^{\circ} \mathrm{C}$ for two of the opaque HLW melts. However, LAWA44, an opaque glass melt, does not show any change in its temperature dependence of thermal diffusivity up to $1150^{\circ} \mathrm{C}$. Presumably, other composition differences, perhaps including iron redox, are responsible for this difference, but further work is required to understand this difference.

The thermal conductivity was calculated from the product of three aforementioned melt properties. With increasing temperature above the glass transition temperature, both the specific heat and density decrease smoothly. The thermal conductivity, however, displays a stronger upward trend 
The Catholic University of America Vitreous State Laboratory
Crystal Settling, Redox, and Properties of ORP HLW \& LAW Glasses

Final Report, VSL-09R1510-1, Rev. 0

with increasing temperature, with the result that the behavior of the thermal conductivity is determined largely by that of the thermal diffusivity. Similar to what was observed in the thermal diffusivity data, the thermal conductivity of ORPLA20, a light colored glass melt, is three or four times that of another LAW glass melt LAWA44 at 800 to $900^{\circ} \mathrm{C}$ and at $1150^{\circ} \mathrm{C}$, respectively. In an un-bubbled melter, such differences could be important in terms of transmission of heat from the glass melt to cold cap materials and, consequently, melting rates. Overall, the thermal conductivity shows significant variation with both temperature and glass composition. 
The Catholic University of America Vitreous State Laboratory
Crystal Settling, Redox, and Properties of ORP HLW \& LAW Glasses

Final Report, VSL-09R1510-1, Rev. 0

\subsection{References}

[4-1] "High Level Waste Vitrification System Improvements," K.S. Matlack, H. Gan, W. Gong, I.L. Pegg, C.C. Chapman, and I. Joseph, Final Report, VSL-07R1010-1, Rev. 0, Vitreous State Laboratory, The Catholic University of America, Washington, DC, 4/16/07.

[4-2] “HLW Glass Formulation Development and Testing," K.S. Matlack, W.K. Kot, H. Gan, I. Joseph, and I.L. Pegg, Test Plan, VSL-08T1520-1, Rev. 0, Vitreous State Laboratory, The Catholic University of America, Washington, DC, 6/18/08.

[4-3] "Glass Formulation to Support Melter Runs with HLW Simulants," Kot, W. K., Klatt, K., and Pegg, I. L., Final Report, VSL-03R3760-2, Rev. 0, Vitreous State Laboratory, The Catholic University of America, Washington, DC, 9/30/03.

[4-4] "Glass Formulation And Testing With RPP-WTP LAW Simulants," I.S. Muller, A.C. Buechele, and I.L. Pegg, Final Report, VSL-01R3560-2, Vitreous State Laboratory, The Catholic University of America, Washington, DC, 2/23/01.

[4-5] "Effects of High Spinel and Chromium Oxide Crystal Contents on Simulated HLW Vitrification in DM100 Melter Tests," K.S. Matlack, W.K. Kot, W. Gong, W. Lutze, I.L. Pegg and I. Joseph, Final Report, VSL-09R1520-1, Rev. 0, Vitreous State Laboratory, The Catholic University of America, Washington, DC, 6/19/09.

[4-6] "Glass Formulation Development and DM10 Melter Testing with ORP LAW Glasses," K. S. Matlack, I. Joseph, W. Gong, I.S. Muller, and I.L. Pegg, Final Report, VSL-09R1510-1, Rev. 0, Vitreous State Laboratory, The Catholic University of America, Washington, DC, 6/12/09.

[4-7] Differential Scanning Calorimeter Procedure, VSL Technical Procedure, TPI-DSC.

[4-8] "Volume-Temperature Relationship in Simulated Glass Forming Nuclear Waste Melts," L.D. Pye, R. Locker and M.H. Plodinec, p627-637, in Advances in Materials Characterization, Materials Science Research Vol. 15, Ed. D.R. Rossington, R.A. Condrate and R.L. Snyder, Plenum Press, New York and London (1983).

[4-9] Thermocouple Calibration, VSL Technical Procedure, TPI-TC.

[4-10] Balance Calibration, VSL Technical Procedure, TPI-BC.

[4-11] "Density of $\mathrm{Na}_{2} \mathrm{O}-\mathrm{K}_{2} \mathrm{O}-\mathrm{CaO}-\mathrm{MgO}-\mathrm{FeO}-\mathrm{Fe}_{2} \mathrm{O}_{3}-\mathrm{Al}_{2} \mathrm{O}_{3}-\mathrm{TiO}_{2}-\mathrm{SiO}_{2}$ Liquids," New Measurements and Derived Partial Molar Properties," R.A. Lange and I.S.E. Carmichael, Geochimica et. Cosmochimica Acta, Vol. 51, 2931-2946, (1987). 
The Catholic University of America Vitreous State Laboratory
Crystal Settling, Redox, and Properties of ORP HLW \& LAW Glasses Final Report, VSL-09R1510-1, Rev. 0

[4-12] "Molten Salts Data as Reference Standards for Density, Surface Tension, Viscosity and Electrical Conductivity: $\mathrm{KNO}_{3}$ and $\mathrm{NaCl}$," G. J. Janz, J. Phys. Chem. Ref. Data 9, 791-829 (1980).

[4-13] Density of Glass, VSL Technical Procedure, TPI-DENS.

[4-14] Determination of the Thermal Diffusivity of Glass Melts by the Method of Sinusoidal Heat Waves, VSL Technical Procedure, TPI-TDG.

[4-15] L.P. Phyllipov, Temperature Wave Techniques, Compendium of Thermophysical Property Measurement Methods, Vol. 1, Survey of Measurement Techniques, ed. K. D. Maglić, A. Cezairliyan, and V. E. Peletsky, Plenum Press, New York and London (1984).

[4-16] "A Method for the Measurement of Thermal Diffusivity of Molten Glass ," A.F. Van Zee and C.L. Babcock, J. of the Am. Ceramic Soc., Vol. 34, 244-250 (1951).

[4-17] West Valley Nuclear Services, Inc., Waste Form Qualification Report, WVDP-186, (1997).

[4-18] P. Richet and Y. Bottinga, Rheology and Configurational Entropy of Silicate Melts, in Reviews in Mineralogy, Vol. 32, Structure, Dynamics and Properties of Silicate Melts, Ed. J.F. Stebbins, P.F. McMillan and D.B. Dingwell, Mineralogical Society of America (1995).

[4-19] C.T. Moynihan, Structural Relaxation and the Glass Transition, in Reviews in Mineralogy, Vol. 32, Structure, Dynamics and Properties of Silicate Melts, Ed. J.F. Stebbins, P.F. McMillan and D.B. Dingwell, Mineralogical Society of America (1995).

[4-20] J.U. Derby, L.D. Pye and M.J. Plodinec, The Measurement of Thermal Diffusivity of Simulated Glass Forming Nuclear Waste Melts, p615-626, in Advances in Materials Characterization, Materials Science Research Vol. 15, Ed. D.R. Rossington, R.A. Condrate and R.L. Snyder, Plenum Press, New York and London (1983).

[4-21] 'Literature Survey of Physical Properties for LAW Container Fill Model,' H. Gan, F. PerezCardenas and I.L. Pegg, Final Report, VSL-99R3610-1,Rev. 0, Vitreous State Laboratory, The Catholic University of America, Washington, DC, 5/7/99.

[4-22] F. Incropera and D.P. DeWitt, Fundamentals of Heat and Mass Transfer, Fourth edition, John Wiley \& Sons (1996). 
The Catholic University of America Vitreous State Laboratory
Crystal Settling, Redox, and Properties of ORP HLW \& LAW Glasses

Final Report, VSL-09R1510-1, Rev. 0

\section{SECTION 5 IMPLICATIONS FOR WTP AND RECOMMENDATIONS FOR FUTURE WORK}

\subsection{Crystal Settling and Glass Melt Rheology}

This work is motivated by the potential for substantial economic benefits that can be realized if glass melters can tolerate a modest amount of crystals at the nominal operating temperature of $1150^{\circ} \mathrm{C}$ because of the associated increase in waste loading. This is because crystal formation is typically the most restrictive waste loading constraint for HLW compositions. Glasses designed for DuraMelter vitrification systems have employed a limit of $<1 \mathrm{vol} \%$ crystals at a reference temperature (typically $950^{\circ} \mathrm{C}$ ) below the operating temperature [5-1]. This is already a less conservative approach than the traditional liquidus temperature requirement (essentially, a 0 vol\% limit). For HLW glass systems, the most common crystalline phases observed after heat treatment at $950^{\circ} \mathrm{C}$ are spinel or oxides rich in $\mathrm{Fe}$, and $\mathrm{Cr}$. The presence of spinel type crystalline phases seldom affects the quality of the glass product, but it can present a significant processing concern since such phases can settle and accumulate in the melter, adversely affecting melter operations and ultimately reducing the life of the melter. Therefore, the waste loading in a glass can be increased if glasses with modest levels of crystals at $1150^{\circ} \mathrm{C}$ can be demonstrated to be processable in a typical waste glass melter. The important underlying phenomena to address are the flow properties of a glass melt with suspended crystals and the settling behavior of the crystals that nucleate, grow, and accumulate during and after the conversion from melter slurry feed to glass melt. The present work employed crucible scale testing to address this need while a parallel effort examined the behavior observed during actual melter testing [5-2].

The most relevant previous crucible studies in this area present conflicting conclusions with respect to the effect of increased spinel crystal content on the flow properties of the melt, with results ranging from rheopectic pseudoplastic to pseudoplastic to, most surprisingly, fully Newtonian, even up to $17 \mathrm{vol} \%$ spinel [5-3, 5-4, 5-5]; however, as noted above, there are ambiguities in the methods and analysis used in some of these studies. There is thus a clear need for a better understanding of the effects of crystal content on glass melt rheology if the potential for increased waste loading through this route is to be realized. The present work addressed the effects of both spinel and eskolaite $\left(\mathrm{Cr}_{2} \mathrm{O}_{3}\right)$. In most cases, the fluids showed non-Newtonian behavior with distinct shear thinning, which was well described by either the Bingham plastic or Herschel-Bulkley rheological models. The effects of both crystal size and vol\% are evident in both the rheological properties and the crystal settling behavior. Larger crystals at lower concentration tended to produce lower yield stress and faster settling, with the converse for smaller crystals at higher concentration. Distinct aging effects were observed in several cases, where the yield stress was observed to increase with time; this can have important implications in terms of the challenges for re-mobilizing settled crystal layers in a melter. 
The Catholic University of America Vitreous State Laboratory
Crystal Settling, Redox, and Properties of ORP HLW \& LAW Glasses

Final Report, VSL-09R1510-1, Rev. 0

The results of the small scale crystal settling experiments showed minor crystal settling at $950^{\circ} \mathrm{C}$ and moderate to extensive settling at 1050 and $1150^{\circ} \mathrm{C}$ under static conditions. In comparison, the data from bubbled DM100 melter tests with HLW glass melts with high crystal contents indicate limited crystal settling for either eskolaite or spinel during normal operation at $1150^{\circ} \mathrm{C}$ and extended idling at $950^{\circ} \mathrm{C}$. Importantly, although the three crystal-bearing melts displayed rather different settling and rheological behavior in the small scale experiments, no difficulties were encountered in the DM100 melter tests that prevented processing the high crystal content HLW melts.

\subsubsection{Recommendations for Future Work}

- In view of the still rather limited set of data that is available on the effects of crystal content on glass melt rheology and settling, there is a clear need for more data on the effects of:

o Crystal type, size, and concentration

o Melt properties

o Aging time

The presently available data are not yet sufficiently extensive to separate the effects of these variables or to fully assess the interplay between them.

- Data are needed to better understand the relationship between the small-scale test results and those observed in melter testing.

- Improved small-scale test methods need to be developed to better capture the effects prevailing in melter environment.

- Data are needed to better understand the effects of active melt pool mixing (bubbling) on settling.

- The origins of the differences in the dominant crystal phases observed in small-scale and melter tests (e.g., hematite) need to be understood.

- Improved methods for spatial sampling throughout the melt pool during melter testing are needed.

- Longer-term melter tests to better assess any chronic effects of crystal settling that may not be evident in short-term tests are needed.

\subsection{V, Cr, and Sn Redox in LAW Glasses}

The broader implication of this work is to support glass formulation methodologies that can increase waste loadings in LAW glasses. More particularly, the work addresses redox effects of certain glass forming additives that could be employed in order to increase waste loadings. 
The Catholic University of America Vitreous State Laboratory
Crystal Settling, Redox, and Properties of ORP HLW \& LAW Glasses Final Report, VSL-09R1510-1, Rev. 0

Typically, the $\mathrm{Fe}^{2+} / \mathrm{Fe}^{3+}$ redox couple provides a convenient probe of the redox state of waste glasses since iron is quite prevalent in typical HLW streams. However, in the case of Hanford LAW, because of the very high $\mathrm{pH}$ of the LAW material, the iron content is very low. Consequently, if iron is not added as a glass former, which could have certain waste loading advantages, both a redox probe and a potential redox buffer have been removed. Instead, if vanadium is added to improve sulfur incorporation, and thereby increase waste loadings, the $\mathrm{V}^{4+} / \mathrm{V}^{5+}$ couple could provide a potential replacement. However, previous studies with vanadium in LAW glasses by VSL/EnergySolutions have shown that, at sufficiently high concentrations, vanadium increases melt foaming, which can result in significantly reduced melt rates and longer melter down-time. Consequently, there is a need to better understand the redox behavior and foaming characteristics of vanadium-containing LAW glasses and the amounts of vanadium that can be added to LAW glasses before deleterious foaming effects ensue. $\mathrm{Cr}$ and $\mathrm{Sn}$ were also studied to compare their behavior in Hanford LAW glasses to those reported previously [5-6]. Four LAW glasses were prepared and heat treated under different conditions expected to provide a range of redox ratios, and the redox states of iron, vanadium, tin and chromium were determined.

The results of this work showed that redox state for the vanadium couple exhibits a generally similar trend and magnitude to those determined from the more conventional iron couple. However, distinct variations in vanadium redox state with glass composition were evident for the same imposed oxygen fugacity and exposure times. The origin of this behavior remains unclear and while it could be an effect of glass basicity, it seems more likely that it is related to interactions between the redox couples, including the possibility of further reduction of chromium to $\mathrm{Cr}^{2+}$. The steady ingrowth of reduced chromium compared to the early in-growth and subsequent decline of reduced vanadium is suggestive of a reaction between these species that consumes the reduced vanadium. Chromium shows significant changes through multiple redox states with increasing reducing conditions, whereas tin remains essentially completely in the tetravalent state over the range of conditions investigated.

\subsubsection{Recommendations for Future Work}

Chromium is prevalent in HLW streams and in the melter materials of construction, and is known to interact with sulfate to increase the tendency for molten sulfate salt formation during LAW vitrification. Consequently, while the present results generally support the replacement of iron by vanadium from a redox perspective, further work would be useful to better understand the interaction with chromium, and the possible effects of glass composition.

\subsection{High Temperature Properties of Selected HLW and LAW Glasses and Melts}

Treatment of radioactive waste streams by vitrification involves high-temperature processing in a glass melter to convert them into stable and durable glass for long term storage. A variety of material properties, both as the melt inside the glass melter and as the solid glass below glass transition temperature, are naturally of importance. Properties to assure processability for an 
The Catholic University of America Vitreous State Laboratory
Crystal Settling, Redox, and Properties of ORP HLW \& LAW Glasses

Final Report, VSL-09R1510-1, Rev. 0

acceptable glass formulation, such as viscosity and electrical conductivity of the melt, are routinely determined experimentally. However, other properties, such as specific heat, density, and thermal conductivity, have been seldom reported, perhaps partly due to the assumption that they are less susceptible to variations with temperature and glass composition, and to a large extent, due to the inherent experimental difficulties in making these high temperature measurements. In particular, these properties are crucial inputs for heat load calculations to assess the impacts of canister filling and cooling. The wide variations in chemical composition of Hanford waste streams have mandated development of waste glasses with rather distinctive chemical compositions [5-7]. This further underscores the need for direct measurement of these key glass properties [5-8]. Despite the importance of these properties, there have been no previous measurements of them for the WTP HLW or LAW glasses.

To address this need, in the present work, four representative WTP waste glasses, two for HLW and two for LAW, were selected for characterization of their high temperature properties. New data have been collected to determine the specific heat, density, thermal diffusivity, and thermal conductivity of representative WTP HLW and LAW compositions over a wide range of temperatures. Despite the importance of these properties, these are the first such measurements on WTP glasses. The results illustrate the rather significant dependence of some of these properties on temperature and glass composition.

\subsubsection{Recommendations for Future Work}

The new data collected in the present study represent an important step forward in view of the lack of other directly relevant data on these properties for WTP LAW and HLW glasses. However, in view of the wide range of glass compositions likely to be processed at the WTP, similar data for other glass compositions would be useful. This is particularly true for the HLW compositions because of the much greater compositional diversity of the Hanford HLW streams. The two HLW glasses studied in the present work are representative of current formulations for ironlimited and aluminum-limited HLW streams. Similar data on glasses representative of other Hanford HLW streams (e.g., those limited by $\mathrm{Cr}, \mathrm{Zr}, \mathrm{Bi}, \mathrm{P}, \mathrm{S}$, etc.) would be useful. For LAW, additional data to span the range of expected sodium loadings would also be useful in order to better understand the likely range in the resulting high temperature properties. 
The Catholic University of America Vitreous State Laboratory
Crystal Settling, Redox, and Properties of ORP HLW \& LAW Glasses Final Report, VSL-09R1510-1, Rev. 0

\section{$5.4 \quad$ References}

[5-1] "Glass Formulation to Support Melter Runs with HLW Simulants," W.K. Kot, K. Klatt, and I.L. Pegg, VSL-03R3760-2, Rev. 0, Vitreous State Laboratory, The Catholic University of America, Washington, DC, 9/30/03.

[5-2] "Effects of High Spinel and Chromium Oxide Crystal Contents on Simulated HLW Vitrification in DM100 Melter Tests," K.S. Matlack, W.K. Kot, W. Gong, W. Lutze, I.L. Pegg and I. Joseph, Final Report, VSL-09R1520-1, Rev. 0, Vitreous State Laboratory, The Catholic University of America, Washington, DC, 6/19/09.

[5-3] "Rheology of Spinel Sludge in Molten Glass," M. Mika, P. Hrma, M.J. Schweiger, CeramicsSilikáty, 44(3) 86-90 (2000).

[5-4] "Structural and Mechanical Response to a Thermo-Rheological History of Spinel Sludge in High-Level Waste Glass," M. Jiřička and P. Hrma, Ceramics-Silikáty, 46(1) 1-7(2002).

[5-5] "The Effect of Spinel Sludge Aging on its Viscosity," M. Mika, M. Liška, and P. Hrma, Ceramics-Silikáty, 46(4) 148-151 (2002).

[5-6] "A comprehensive electromotive force series of redox couples in soda-lime-silicate glass," H.D. Schreiber, N.R. Wilk, C.W. Schreiber, J. Non-Crystalline Solids 253, 68-75 (1999).

[5-7] K.S. Matlack, H. Gan, W. Gong, I.L. Pegg, C.C. Chapman, and I. Joseph High Level Waste Vitrification System Improvements, Final Report, VSL-07R1010-1, Rev. 0, Vitreous State Laboratory, The Catholic University of America, Washington, DC, 4/16/07.

[5-8] K.S. Matlack, W.K. Kot, H. Gan, I. Joseph, and I.L. Pegg, HLW Glass Formulation Development and Testing, Test Plan, VSL-08T1520-1, Rev. 0, Vitreous State Laboratory, The Catholic University of America, Washington, DC, 6/18/08. 
Table 2.1. Target Composition of HLW Glasses for Crystal Settling and Rheology Characterization (wt\%).

\begin{tabular}{|c|c|c|c|}
\hline Melter Test & Test 1 & Test 2 & Not Tested \\
\hline Target Glass & HLW-E-SP-06 & HLW-E-SP-05 & HLW-E-ES-02 \\
\hline $\mathrm{Al}_{2} \mathrm{O}_{3}$ & 8.91 & 9.49 & 12.36 \\
\hline $\mathrm{B}_{2} \mathrm{O}_{3}$ & 13.30 & 12.08 & 13.55 \\
\hline $\mathrm{BaO}$ & - & - & 0.01 \\
\hline $\mathrm{Bi}_{2} \mathrm{O}_{3}$ & - & - & 3.53 \\
\hline $\mathrm{CaO}$ & 0.37 & 0.40 & 1.20 \\
\hline $\mathrm{CdO}$ & 0.18 & 0.19 & \\
\hline $\mathrm{Cr}_{2} \mathrm{O}_{3}$ & 0.15 & 0.15 & 3.00 \\
\hline $\mathrm{Cs}_{2} \mathrm{O}$ & 0.08 & 0.08 & - \\
\hline $\mathrm{F}$ & - & - & 0.97 \\
\hline $\mathrm{Fe}_{2} \mathrm{O}_{3}$ & 20.01 & 21.30 & 6.36 \\
\hline $\mathrm{K}_{2} \mathrm{O}$ & 7.00 & 7.01 & 4.61 \\
\hline $\mathrm{La}_{2} \mathrm{O}_{3}$ & 0.60 & 0.64 & - \\
\hline $\mathrm{Li}_{2} \mathrm{O}$ & 1.17 & 1.10 & 2.64 \\
\hline $\mathrm{MgO}$ & 0.11 & 0.12 & 0.08 \\
\hline $\mathrm{MnO}$ & 0.57 & 0.61 & - \\
\hline $\mathrm{Na}_{2} \mathrm{O}$ & 10.19 & 9.07 & 9.72 \\
\hline $\mathrm{Nd}_{2} \mathrm{O}_{3}$ & 0.26 & 0.28 & - \\
\hline $\mathrm{NiO}$ & 0.71 & 0.76 & - \\
\hline $\mathrm{P}_{2} \mathrm{O}_{5}$ & 0.04 & 0.04 & 1.62 \\
\hline $\mathrm{PbO}$ & 0.11 & 0.12 & 0.23 \\
\hline $\mathrm{SO}_{3}$ & 0.07 & 0.07 & - \\
\hline $\mathrm{SiO}_{2}$ & 33.31 & 33.46 & 40.07 \\
\hline $\mathrm{ZnO}$ & 0.02 & 0.02 & - \\
\hline $\mathrm{ZrO}_{2}$ & 2.83 & 3.01 & 0.05 \\
\hline
\end{tabular}

-Empty data field 
Table 2.2. Summary of Key Properties of the Three HLW Glasses/Melts [2-8].

\begin{tabular}{|c|c|c|c|c|}
\hline \multicolumn{2}{|c|}{ PROPERTY } & HLW-E-ES-02 & HLW-E-SP-05 & HLW-E-SP-06 \\
\hline \multirow{7}{*}{ Crystal Content (a) } & $\begin{array}{l}\text { As-Melted at } \\
1200^{\circ} \mathrm{C}(\text { vol } \%)\end{array}$ & $1.8(\mathrm{ES})$ & $1.5(\mathrm{Sp})$ & $0.4(\mathrm{Sp})$ \\
\hline & $\begin{array}{c}\text { After HT at } \\
1150^{\circ} \mathrm{C}(\mathrm{vol} \%)\end{array}$ & $1.6(\mathrm{ES})$ & $2.9(\mathrm{Sp})$ & $1.3(\mathrm{Sp})$ \\
\hline & $\begin{array}{c}\text { After HT at } \\
1100^{\circ} \mathrm{C}(\mathrm{vol} \%)\end{array}$ & $1.3(\mathrm{ES})$ & $4.0(\mathrm{Sp})$ & $1.0(\mathrm{Sp})$ \\
\hline & $\begin{array}{c}\text { After HT at } \\
1000^{\circ} \mathrm{C}(\mathrm{vol} \%)\end{array}$ & $2.0(\mathrm{ES})$ & $4.0(\mathrm{Sp}, \mathrm{Fe})$ & $1.4(\mathrm{Sp})$ \\
\hline & $\begin{array}{l}\text { After HT at } \\
950^{\circ} \mathrm{C}(\text { vol } \%)\end{array}$ & 2.0 (ES) & $4.2(\mathrm{Sp})$ & $2.2(\mathrm{Sp})$ \\
\hline & $\begin{array}{l}\text { After HT at } \\
900^{\circ} \mathrm{C}(\text { vol } \%)\end{array}$ & $1.7(\mathrm{ES})$ & $5.2(\mathrm{Sp})$ & $2.9(\mathrm{Sp})$ \\
\hline & $\begin{array}{c}\text { Approximate } \\
\text { Average Particle } \\
\text { Size }\end{array}$ & $22 \mu \mathrm{m}$ & $5 \mu \mathrm{m}$ & $10 \mu \mathrm{m}$ \\
\hline \multirow{4}{*}{ Viscosity $(\mathrm{P})$} & $950^{\circ} \mathrm{C}$ & $807.7\left(961^{\circ} \mathrm{C}\right)^{(\mathrm{b})}$ & $3250.9\left(960^{\circ} \mathrm{C}\right)^{(\mathrm{b})}$ & $323.1\left(963^{\circ} \mathrm{C}\right)^{(b)}$ \\
\hline & $1050^{\circ} \mathrm{C}$ & $336.5\left(1062^{\circ} \mathrm{C}\right)$ & $222.1\left(1060^{\circ} \mathrm{C}\right)$ & $107.7\left(1062^{\circ} \mathrm{C}\right)$ \\
\hline & $1150^{\circ} \mathrm{C}$ & $141.3\left(1164^{\circ} \mathrm{C}\right)$ & $60.6\left(1162^{\circ} \mathrm{C}\right)$ & $40.4\left(1161^{\circ} \mathrm{C}\right)$ \\
\hline & $1250^{\circ} \mathrm{C}$ & $80.8\left(1265^{\circ} \mathrm{C}\right)$ & $33.7\left(1263^{\circ} \mathrm{C}\right)$ & NA \\
\hline \multirow{5}{*}{$\begin{array}{l}\text { Electrical Conductivity } \\
\qquad(\mathrm{S} / \mathrm{cm})\end{array}$} & $950^{\circ} \mathrm{C}$ & - & 0.076 & 0.078 \\
\hline & $1000^{\circ} \mathrm{C}$ & - & 0.096 & 0.105 \\
\hline & $1050^{\circ} \mathrm{C}$ & - & 0.119 & 0.137 \\
\hline & $1100^{\circ} \mathrm{C}$ & - & 0.145 & 0.175 \\
\hline & $1150^{\circ} \mathrm{C}$ & - & 0.175 & 0.218 \\
\hline \multirow{3}{*}{ Normalized PCT (7-Day) } & $\mathrm{B}(\mathrm{g} / \mathrm{l})$ & 1.303 & 1.229 & 0.521 \\
\hline & $\mathrm{Li}(\mathrm{g} / \mathrm{l})$ & 1.044 & 1.036 & 0.227 \\
\hline & $\mathrm{Na}(\mathrm{g} / \mathrm{l})$ & 0.828 & 0.955 & 0.568 \\
\hline
\end{tabular}

(a) Glass melting time $=2$ hours, Heat treatment time $=70$ hours, ES $=$ eskolaite (with minor amounts of iron incorporated), $\mathrm{Sp}=$ spinel

- Empty data field (Not Analyzed).

(b) Fitting of viscosity data not performed because non-Newtonian behavior observed.

Apparent viscosity data measured at selected shear rate $(1.51 / \mathrm{s})$ and temperatures are reported. 
Table 2.3. Size Estimation of Major Crystalline Phase After Crystal Settling Experiments. Optical microscopy on thin sections from crystal settling experiments and SEM on samples from isothermal heat treatment (70 hours). Note that the dominant grain size is shown in bold font.

\begin{tabular}{|c|c|c|c|c|c|c|c|}
\hline $\begin{array}{l}\text { Glass } \\
\text { Name }\end{array}$ & $\begin{array}{c}\text { Temperature } \\
\left({ }^{\circ} \mathrm{C}\right)\end{array}$ & $\begin{array}{c}\text { Idling } \\
\text { Time } \\
\text { (hours) }\end{array}$ & $\begin{array}{c}\text { Thin Section } \\
\text { Thickness } \\
(\mu \mathrm{m})\end{array}$ & $\begin{array}{l}\text { Typical Larger Grain } \\
\text { Size }(\mu \mathrm{m}) \\
{[\mathrm{x} / \mathrm{y} \text { indicates platelet }} \\
\text { aspect ratio }]\end{array}$ & $\begin{array}{c}\text { Typical Smaller } \\
\text { Grain Size }(\mu \mathrm{m}) \\
\text { [x/y indicates platelet } \\
\text { aspect ratio] }\end{array}$ & $\begin{array}{c}\text { Maximum } \\
\text { Grain Size } \\
\text { by SEM } \\
(70 \text { hours } \\
\text { isothermal }) \\
(\mu \mathrm{m})\end{array}$ & $\begin{array}{c}\text { Average Grain } \\
\text { Size by SEM } \\
\text { (70 hours } \\
\text { isothermal) } \\
(\mu \mathrm{m}) \\
\end{array}$ \\
\hline \multirow{12}{*}{$\begin{array}{l}\text { ò } \\
1 \\
1 \\
11 \\
1 \\
1 \\
3 \\
1\end{array}$} & \multirow{4}{*}{950} & 3.5 & 280 & $23 / 17,43 / 20$ & $11 / 6,8.5 / 6$ & \multirow{4}{*}{95} & \multirow{4}{*}{35} \\
\hline & & 7 & 280 & $\begin{array}{l}14 / 8,20 / 14,26 / 17 \\
15 / 10\end{array}$ & $7 / 3,9 / 7$ & & \\
\hline & & 14 & 530 & $\begin{array}{l}23 / 11,85 / 43 \\
37 / 17,28 / 14\end{array}$ & $\begin{array}{l}\text { 17/3, 14/3, 17/11, } \\
17 / 9.10 / 7\end{array}$ & & \\
\hline & & 28 & 720 & $\begin{array}{l}26 / 14,20 / 14, \\
20 / 17\end{array}$ & $17 / 8,17 / 6$ & & \\
\hline & \multirow{4}{*}{1050} & 3.5 & 370 & $43 / 23,23 / 17,20 / 9$ & $7 / 3,9 / 2$ & \multirow{4}{*}{$\begin{array}{c}160-220 \\
(1000- \\
\left.1100^{\circ} \mathrm{C}\right)\end{array}$} & \multirow{4}{*}{$\begin{array}{c}17-16 \\
(1000- \\
\left.1100^{\circ} \mathrm{C}\right)\end{array}$} \\
\hline & & 7 & 650 & $\begin{array}{l}85 / 71,57 / 28, \\
34 / 17\end{array}$ & $\begin{array}{l}11 / 6,7 / 4,20 / 6, \\
17 / 8\end{array}$ & & \\
\hline & & 14 & 550 & $\begin{array}{l}28 / 17,28 / 20, \\
23 / 14,15 / 8\end{array}$ & $8 / 4,9 / 7,7 / 3$ & & \\
\hline & & 28 & 480 & $34 / 17,34 / 28$ & $14 / 5,17 / 5$ & & \\
\hline & \multirow{4}{*}{1150} & 3.5 & 230 & \multirow{4}{*}{\multicolumn{2}{|c|}{ Not Analyzed }} & \multirow{4}{*}{68} & \multirow{4}{*}{19} \\
\hline & & 7 & 210 & & & & \\
\hline & & 14 & 230 & & & & \\
\hline & & 28 & 140 & & & & \\
\hline \multirow{12}{*}{$\begin{array}{l}0 \\
0 \\
1 \\
01 \\
1 \\
1 \\
1 \\
3 \\
1\end{array}$} & \multirow{4}{*}{950} & 3.5 & 320 & 11,9 & $3,4,6$ & \multirow{4}{*}{\multicolumn{2}{|c|}{5}} \\
\hline & & 7 & 310 & 11,9 & $3,4,6$ & & \\
\hline & & 14 & 240 & $20,17,14,13,11$ & $3,4,6$ & & \\
\hline & & 28 & 350 & $23,20,19,17,11$ & 6,8 & & \\
\hline & \multirow{4}{*}{1050} & 3.5 & 450 & $14,11,9$ & 3,4 & \multirow{4}{*}{\multicolumn{2}{|c|}{$\begin{array}{c}\mathbf{5 - 4} \\
\left(1000-1100^{\circ} \mathrm{C}\right)\end{array}$}} \\
\hline & & 7 & 320 & $11,9,8$ & 5,3 & & \\
\hline & & 14 & 310 & $11,9,7,8$ & $3,4,6$ & & \\
\hline & & 28 & 320 & $16,14,11$ & $3,4,6$ & & \\
\hline & \multirow{4}{*}{1150} & 3.5 & 310 & \multirow{4}{*}{\multicolumn{2}{|c|}{ Not Analyzed }} & \multirow{4}{*}{\multicolumn{2}{|c|}{8}} \\
\hline & & 7 & 330 & & & & \\
\hline & & 14 & 250 & & & & \\
\hline & & 28 & 350 & & & & \\
\hline \multirow{12}{*}{$\begin{array}{l}0 \\
0 \\
i \\
01 \\
1 \\
11 \\
3 \\
3\end{array}$} & \multirow{4}{*}{950} & 3.5 & 340 & 14,11 & $3,4,6$ & \multirow{4}{*}{\multicolumn{2}{|c|}{15}} \\
\hline & & 7 & 350 & $26,20,17,13,10$ & 6,8 & & \\
\hline & & 14 & 360 & $20,17,14,13,11$ & 6,8 & & \\
\hline & & 28 & 390 & $\begin{array}{l}33,31,28,26,25, \\
23\end{array}$ & 6,8 & & \\
\hline & \multirow{4}{*}{1050} & 3.5 & 400 & 11,9 & $3,4,6$ & \multirow{4}{*}{\multicolumn{2}{|c|}{$\begin{array}{c}\mathbf{1 5 - 8} \\
\left(1000-1100^{\circ} \mathrm{C}\right)\end{array}$}} \\
\hline & & 7 & 200 & $16,15,14$ & $3,4,6$ & & \\
\hline & & 14 & 340 & $23,20,17,15,11$ & 6,8 & & \\
\hline & & 28 & 180 & $20,16,12,11$ & $3,4,6$ & & \\
\hline & \multirow{4}{*}{1150} & 3.5 & 350 & \multirow{4}{*}{\multicolumn{2}{|c|}{ Not Analyzed }} & \multirow{4}{*}{\multicolumn{2}{|c|}{10}} \\
\hline & & 7 & 310 & & & & \\
\hline & & 14 & 240 & & & & \\
\hline & & 28 & 350 & & & & \\
\hline
\end{tabular}


Table 2.4a. Relative Torque vs. RPM (revolutions per minute) for HLW-E-ES-02 at a Given Test Temperature and Holding Time.

\begin{tabular}{|c|c|c|c|c|c|c|c|c|c|c|c|c|}
\hline \multirow{2}{*}{$\begin{array}{c}\text { Temp. } \\
\left({ }^{\circ} \mathrm{C}\right)\end{array}$} & Time & \multicolumn{10}{|c|}{ Torque \% } \\
\cline { 3 - 17 } & $0.5 \mathrm{rpm}$ & $1 \mathrm{rpm}$ & $2.5 \mathrm{rpm}$ & $5 \mathrm{rpm}$ & $10 \mathrm{rpm}$ & $20 \mathrm{rpm}$ & $50 \mathrm{rpm}$ & $75 \mathrm{rpm}$ & $100 \mathrm{rpm}$ & $150 \mathrm{rpm}$ & $200 \mathrm{rpm}$ \\
\hline 1265 & 0 & $0.2^{*}$ & 0.4 & 0.8 & 1.2 & 1.9 & 3.1 & 6.4 & 9.0 & 11.4 & 16.4 & 21.6 \\
\hline 1265 & 1 & $0.2^{*}$ & 0.4 & 0.8 & 1.2 & 1.9 & 3.2 & 6.6 & 9.2 & 11.6 & 16.7 & 21.7 \\
\hline 1265 & 2 & $0.2^{*}$ & 0.4 & 0.8 & 1.2 & 1.9 & 3.2 & 6.6 & 9.2 & 11.6 & 16.8 & 21.7 \\
\hline 1164 & 0 & 0.4 & 0.7 & 1.2 & 2.1 & 3.6 & 6.3 & 14.4 & 20.6 & 27.0 & 39.4 & 50.8 \\
\hline 1164 & 1 & $0.3 *$ & 0.6 & 1.1 & 1.9 & 3.4 & 6.1 & 13.7 & 19.9 & 26.1 & 38.5 & 50.0 \\
\hline 1164 & 2 & $0.3 *$ & 0.6 & 1.0 & 1.8 & 3.2 & 5.9 & 13.4 & 19.7 & 25.9 & 38.2 & 50.0 \\
\hline 1062 & 0 & 1.1 & 1.6 & 3.0 & 5.0 & 8.7 & 15.3 & 34.5 & 49.1 & 64.0 & 91.9 & \\
\hline 1062 & 1 & 0.6 & 1.0 & 2.1 & 3.8 & 7.1 & 13.3 & 31.7 & 46.8 & 61.9 & 90.0 & \\
\hline 1062 & 2 & 0.6 & 1.0 & 2.1 & 3.8 & 7.0 & 13.0 & 31.0 & 45.8 & 60.7 & 88.3 & \\
\hline 1062 & 4 & 0.6 & 1.0 & 2.1 & 3.8 & 6.9 & 12.9 & 30.4 & 44.8 & 59.4 & 87.5 & \\
\hline 961 & 0 & 1.8 & 3.2 & 6.8 & 12.0 & 22.1 & 41.2 & 93.3 & & & & \\
\hline 961 & 1 & 1.1 & 2.2 & 5.1 & 9.9 & 19.3 & 37.9 & 91.7 & & & \\
\hline 961 & 2 & 1.1 & 2.1 & 5.0 & 9.8 & 19.1 & 37.2 & 91.2 & & & \\
\hline 961 & 4 & 1.1 & 2.1 & 5.0 & 9.8 & 19.1 & 37.2 & 90.3 & & & \\
\hline 961 & 24 & 1.3 & 2.4 & 5.2 & 9.9 & 19.1 & 36.6 & 88.4 & & & \\
\hline
\end{tabular}

* Large relative error 
ORP-56295 Rev. 0

The Catholic University of America Vitreous State Laboratory
Crystal Settling, Redox, and Properties of ORP HLW \& LAW Glasses

Final Report, VSL-09R1510-1, Rev. 0

Table 2.4b. Viscosity vs. Shear Rate for HLW-E-ES-02 at a Given Test Temperature and Holding Time.

\begin{tabular}{|c|c|c|c|c|c|c|c|c|c|c|c|c|}
\hline \multirow{2}{*}{$\begin{array}{c}\text { Temp. } \\
\left({ }^{\circ} \mathrm{C}\right)\end{array}$} & \multirow{2}{*}{$\begin{array}{l}\text { Time } \\
(\mathrm{Hr})\end{array}$} & \multicolumn{11}{|c|}{ Viscosity (Poise) } \\
\hline & & $0.151 / \mathrm{s}$ & $0.311 / \mathrm{s}$ & $0.771 / \mathrm{s}$ & $1.541 / \mathrm{s}$ & $3.081 / \mathrm{s}$ & $6.171 / \mathrm{s}$ & $15.421 / \mathrm{s}$ & $23.121 / \mathrm{s}$ & $30.831 / \mathrm{s}$ & $46.251 / \mathrm{s}$ & $61.661 / \mathrm{s}$ \\
\hline 1265 & 0 & $134.6^{*}$ & 134.6 & 107.7 & 80.8 & 63.9 & 52.2 & 43.1 & 40.4 & 38.4 & 36.8 & 36.3 \\
\hline 1265 & 1 & $134.6^{*}$ & 134.6 & 107.7 & 80.8 & 63.9 & 53.8 & 44.4 & 41.3 & 39.0 & 37.5 & 36.5 \\
\hline 1265 & 2 & $134.6^{*}$ & 134.6 & 107.7 & 80.8 & 63.9 & 53.8 & 44.4 & 41.3 & 39.0 & 37.7 & 36.5 \\
\hline 1164 & 0 & 269.2 & 235.6 & 161.5 & 141.3 & 121.2 & 106.0 & 96.9 & 92.4 & 90.9 & 88.4 & 85.5 \\
\hline 1164 & 1 & $201.9 *$ & 201.9 & 148.1 & 127.9 & 114.4 & 102.6 & 92.2 & 89.3 & 87.8 & 86.4 & 84.1 \\
\hline 1164 & 2 & $201.9 *$ & 201.9 & 134.6 & 121.2 & 107.7 & 99.3 & 90.2 & 88.4 & 87.2 & 85.7 & 84.1 \\
\hline 1062 & 0 & 740.4 & 538.5 & 403.8 & 336.5 & 292.8 & 257.4 & 232.2 & 220.3 & 215.4 & 206.2 & \\
\hline 1062 & 1 & 403.8 & 336.5 & 282.7 & 255.8 & 238.9 & 223.8 & 213.4 & 210.0 & 208.3 & 201.9 & \\
\hline 1062 & 2 & 403.8 & 336.5 & 282.7 & 255.8 & 235.6 & 218.7 & 208.7 & 205.5 & 204.3 & 198.1 & \\
\hline 1062 & 4 & 403.8 & 336.5 & 282.7 & 255.8 & 232.2 & 217.1 & 204.6 & 201.0 & 199.9 & 196.3 & \\
\hline 961 & 0 & 1211.5 & 1076.9 & 915.4 & 807.7 & 743.7 & 693.3 & 628.0 & & & & \\
\hline 961 & 1 & 740.4 & 740.4 & 686.5 & 666.3 & 649.5 & 637.7 & 617.2 & & & & \\
\hline 961 & 2 & 740.4 & 706.7 & 673.1 & 659.6 & 642.8 & 626.0 & 613.8 & & & & \\
\hline 961 & 4 & 740.4 & 706.7 & 673.1 & 659.6 & 642.8 & 626.0 & 607.8 & & & & \\
\hline 961 & 24 & 875.0 & 807.7 & 700.0 & 666.3 & 642.8 & 615.9 & 595.0 & & & & \\
\hline
\end{tabular}

* Large relative error 
Table 2.5a. Relative Torque vs. RPM (revolutions per minute) for HLW-E-SP-05 at a Given Test Temperature and Holding Time.

\begin{tabular}{|c|c|c|c|c|c|c|c|c|c|c|c|c|}
\hline \multirow{2}{*}{ Temp. $\left({ }^{\circ} \mathrm{C}\right)$} & \multirow{2}{*}{ Time $(\mathrm{Hr})$} & \multicolumn{10}{|c|}{ Torque \% } \\
\cline { 2 - 13 } & & $0.5 \mathrm{rpm}$ & $1 \mathrm{rpm}$ & $2.5 \mathrm{rpm}$ & $5 \mathrm{rpm}$ & $10 \mathrm{rpm}$ & $20 \mathrm{rpm}$ & $50 \mathrm{rpm}$ & $75 \mathrm{rpm}$ & $100 \mathrm{rpm}$ & $150 \mathrm{rpm}$ & $200 \mathrm{rpm}$ \\
\hline 1263 & 0 & $0.1 *$ & $0.2^{*}$ & $0.3^{*}$ & 0.5 & 0.9 & 1.6 & 3.7 & 5.5 & 7.3 & 10.7 & 14.2 \\
\hline 1263 & 1 & $0.1^{*}$ & $0.2^{*}$ & $0.3^{*}$ & 0.5 & 0.8 & 1.5 & 3.5 & 5.2 & 6.8 & 10.1 & 13.4 \\
\hline 1263 & 2 & $0.1^{*}$ & $0.2^{*}$ & $0.3^{*}$ & 0.4 & 0.7 & 1.4 & 3.4 & 5.0 & 6.6 & 9.9 & 13.1 \\
\hline 1162 & 0 & $0.1 *$ & $0.2^{*}$ & 0.5 & 0.9 & 1.9 & 3.7 & 9.3 & 13.8 & 18.5 & 27.6 & 37.0 \\
\hline 1162 & 1 & $0.1 *$ & $0.2^{*}$ & 0.5 & 1.0 & 2.0 & 4.0 & 9.8 & 14.7 & 19.6 & 29.3 & 39.1 \\
\hline 1162 & 2 & $0.1 *$ & $0.2 *$ & 0.5 & 1.0 & 2.0 & 4.0 & 9.9 & 14.8 & 19.7 & 29.4 & 39.3 \\
\hline 1060 & 0 & 0.5 & 0.8 & 1.8 & 3.3 & 6.4 & 12.0 & 29.0 & 43.2 & 57.5 & 86.7 & \\
\hline 1060 & 1 & 1.8 & 3.1 & 5.2 & 8.1 & 13.0 & 22.0 & 47.0 & 67.2 & 86.5 & \\
\hline 1060 & 2 & 2.2 & 3.5 & 5.7 & 8.4 & 13.3 & 22.1 & 47.4 & 67.4 & 87.0 & \\
\hline 1060 & 4 & 2.4 & 3.7 & 5.9 & 8.6 & 13.4 & 22.4 & 47.9 & 68.5 & 88.4 & \\
\hline 960 & 0 & 10.9 & 17.3 & 30.9 & 48.3 & 76.0 & & & & & \\
\hline 960 & 1 & 14.8 & 20.1 & 32.1 & 48.4 & 75.9 & & & & & \\
\hline 960 & 2 & 16.0 & 22.2 & 35.5 & 52.7 & 80.8 & & & & & \\
\hline 960 & 4 & 16.4 & 22.6 & 35.5 & 52.5 & 80.7 & & & & & \\
\hline 960 & 24 & 16.5 & 22.0 & 32.8 & 47.0 & 72.2 & & & & & \\
\hline
\end{tabular}

* Large relative error 
Table 2.5b. Viscosity vs. Shear Rate for HLW-E-SP-05 at a Given Test Temperature and Holding Time.

\begin{tabular}{|c|c|c|c|c|c|c|c|c|c|c|c|c|}
\hline $\begin{array}{c}\text { Temp } \\
\left({ }^{\circ} \mathrm{C}\right)\end{array}$ & $\begin{array}{l}\text { Time } \\
(\mathrm{Hr})\end{array}$ & \multicolumn{11}{|c|}{ Viscosity (Poise) } \\
\hline 1263 & 0 & $67.31 *$ & $67.31^{*}$ & $40.38^{*}$ & 33.7 & 30.3 & 26.9 & 24.9 & 24.7 & 24.6 & 24.0 & 23.9 \\
\hline 1263 & 1 & $67.31 *$ & $67.31^{*}$ & $40.38^{*}$ & 33.7 & 26.9 & 25.2 & 23.6 & 23.3 & 22.9 & 22.7 & 22.5 \\
\hline 1263 & 2 & $67.31 *$ & $67.31^{*}$ & $40.38^{*}$ & 26.9 & 23.6 & 23.6 & 22.9 & 22.4 & 22.2 & 22.2 & 22.0 \\
\hline 1162 & 1 & $67.31 *$ & $67.31^{*}$ & 67.3 & 67.3 & 67.3 & 67.3 & 66.0 & 66.0 & 66.0 & 65.7 & 65.8 \\
\hline 1162 & 2 & $67.31 *$ & $67.31^{*}$ & 67.3 & 67.3 & 67.3 & 67.3 & 66.6 & 66.4 & 66.3 & 66.0 & 66.1 \\
\hline 1060 & 0 & 336.5 & 269.2 & 242.3 & 222.1 & 215.4 & 201.9 & 195.2 & 193.8 & 193.5 & 194.5 & \\
\hline 1060 & 1 & 1211.5 & 1043.3 & 700.0 & 545.2 & 437.5 & 370.2 & 316.3 & 301.5 & 291.1 & & \\
\hline 960 & 0 & 7336.4 & 5822.0 & 4159.5 & 3250.9 & 2557.7 & & & & & & \\
\hline 960 & 1 & 9961.4 & 6764.3 & 4321.1 & 3257.6 & 2554.3 & & & & & & \\
\hline 960 & 2 & 10769.1 & 7471.0 & 4778.8 & 3547.1 & 2719.2 & & & & & & \\
\hline 960 & 4 & 11038.3 & 7605.6 & 4778.8 & 3533.6 & 2715.8 & & & & & & \\
\hline 960 & 24 & 11105.6 & 7403.7 & 4415.3 & 3163.4 & 2429.8 & & & & & & \\
\hline
\end{tabular}

* Large relative error 
Table 2.6a. Relative Torque vs. RPM (revolutions per minute) for HLW-E-SP-06 at a Given Test Temperature and Holding Time.

\begin{tabular}{|c|c|c|c|c|c|c|c|c|c|c|c|c|}
\hline \multirow{2}{*}{$\begin{array}{c}\text { Temp. } \\
\left({ }^{\circ} \mathrm{C}\right)\end{array}$} & \multirow{2}{*}{$\begin{array}{l}\text { Time } \\
(\mathrm{Hr})\end{array}$} & \multicolumn{11}{|c|}{ Torque $\%$} \\
\hline & & $0.5 \mathrm{rpm}$ & $1 \mathrm{rpm}$ & $2.5 \mathrm{rpm}$ & $5 \mathrm{rpm}$ & 10rpm & 20rpm & 50rpm & $75 \mathrm{rpm}$ & 100rpm & $150 \mathrm{rpm}$ & 200rpm \\
\hline 1161 & 0 & $0.1^{*}$ & $0.2^{*}$ & 0.4 & 0.6 & 1.2 & 2.4 & 5.9 & 8.7 & 11.6 & 17.4 & 23.1 \\
\hline 1161 & 1 & $0.2 *$ & $0.2^{*}$ & 0.4 & 0.7 & 1.3 & 2.4 & 5.7 & 8.4 & 11.1 & 16.5 & 22.0 \\
\hline 1062 & 0 & 0.3 & 0.4 & 0.9 & 1.6 & 3.0 & 5.9 & 14.5 & 21.6 & 28.7 & 43.0 & 57.3 \\
\hline 1062 & 1 & 0.3 & 0.4 & 0.9 & 1.6 & 3.0 & 6.0 & 14.5 & 21.7 & 28.9 & 43.3 & 57.7 \\
\hline 1062 & 2 & 0.3 & 0.4 & 0.9 & 1.6 & 3.1 & 6.0 & 14.6 & 21.8 & 29.1 & 43.6 & 58.2 \\
\hline 1062 & 4 & 0.3 & 0.4 & 0.9 & 1.6 & 3.1 & 6.1 & 14.8 & 22.2 & 29.5 & 44.2 & 59.0 \\
\hline 963 & 0 & 0.4 & 0.9 & 2.4 & 4.8 & 9.6 & 19.2 & 47.9 & 71.8 & 95.8 & & \\
\hline 963 & 1 & 0.5 & 1.0 & 2.5 & 4.9 & 9.8 & 19.5 & 48.6 & 72.8 & 97.1 & & \\
\hline 963 & 2 & 0.7 & 1.3 & 3.1 & 5.9 & 11.0 & 21.0 & 51.0 & 75.2 & 99.9 & & \\
\hline 963 & 4 & 1.0 & 2.0 & 4.4 & 7.8 & 14.0 & 25.0 & 56.0 & 82.2 & & & \\
\hline 963 & 24 & 1.1 & 2.0 & 4.2 & 7.3 & 13.5 & 25.5 & 60.5 & 88.9 & & & \\
\hline
\end{tabular}

* Large relative error 
Table 2.6b. Viscosity vs. Shear Rate for HLW-E-SP-06 at a Given Test Temperature and Holding Time.

\begin{tabular}{|c|c|c|c|c|c|c|c|c|c|c|c|c|}
\hline \multirow{2}{*}{$\begin{array}{c}\text { Temp. } \\
\left({ }^{\circ} \mathrm{C}\right)\end{array}$} & \multirow{2}{*}{$\begin{array}{c}\text { Time } \\
(\mathrm{Hr})\end{array}$} & $\begin{array}{c}0.15 \\
1 / \mathrm{s}\end{array}$ & $\begin{array}{c}0.31 \\
1 / \mathrm{s}\end{array}$ & $\begin{array}{c}0.77 \\
1 / \mathrm{s}\end{array}$ & $\begin{array}{c}1.54 \\
1 / \mathrm{s}\end{array}$ & $\begin{array}{c}3.08 \\
1 / \mathrm{s}\end{array}$ & $\begin{array}{c}6.17 \\
1 / \mathrm{s}\end{array}$ & $\begin{array}{c}15.42 \\
1 / \mathrm{s}\end{array}$ & $\begin{array}{c}23.12 \\
1 / \mathrm{s}\end{array}$ & $\begin{array}{c}30.83 \\
1 / \mathrm{s}\end{array}$ & $\begin{array}{c}46.25 \\
1 / \mathrm{s}\end{array}$ & $\begin{array}{c}61.66 \\
1 / \mathrm{s}\end{array}$ \\
\hline 1161 & 0 & $67.3 *$ & $67.3^{*}$ & 53.8 & 40.4 & 40.4 & 40.4 & 39.7 & 39.0 & 39.0 & 39.0 & 38.9 \\
\hline 1161 & 1 & $134.6^{*}$ & $67.3 *$ & 53.8 & 47.1 & 43.7 & 40.4 & 38.4 & 37.7 & 37.4 & 37.0 & 37.0 \\
\hline 1062 & 0 & 201.9 & 134.6 & 121.2 & 107.7 & 101.0 & 99.3 & 97.6 & 96.9 & 96.6 & 96.5 & 96.4 \\
\hline 1062 & 1 & 201.9 & 134.6 & 121.2 & 107.7 & 101.0 & 101.0 & 97.6 & 97.4 & 97.3 & 97.1 & 97.1 \\
\hline 1062 & 2 & 201.9 & 134.6 & 121.2 & 107.7 & 104.3 & 101.0 & 98.3 & 97.8 & 97.9 & 97.8 & 97.9 \\
\hline 1062 & 4 & 201.9 & 134.6 & 121.2 & 107.7 & 104.3 & 102.6 & 99.6 & 99.6 & 99.3 & 99.2 & 99.3 \\
\hline 963 & 0 & 269.2 & 302.9 & 323.1 & 323.1 & 323.1 & 323.1 & 322.4 & 322.2 & 322.4 & \\
\hline 963 & 1 & 336.5 & 336.5 & 336.5 & 329.8 & 329.8 & 328.1 & 327.1 & 326.7 & 326.8 & \\
\hline 963 & 2 & 471.1 & 437.5 & 417.3 & 397.1 & 370.2 & 353.4 & 343.3 & 337.4 & 336.2 & \\
\hline 963 & 4 & 673.1 & 673.1 & 592.3 & 525.0 & 471.1 & 420.7 & 376.9 & 368.8 & & \\
\hline 963 & 24 & 740.4 & 673.1 & 565.4 & 491.3 & 454.3 & 429.1 & 407.2 & 398.9 & & \\
\hline
\end{tabular}

* Large relative error 


\section{Table 2.7. Yield Stress Measurement and Analysis of the Relationship of Shear Stress vs. Shear Rate} for HLW-E-ES-02.

\begin{tabular}{|c|c|c|c|c|c|c|c|}
\hline \multirow[t]{2}{*}{$\begin{array}{c}\text { Temperature } \\
\left({ }^{\circ} \mathrm{C}\right)\end{array}$} & \multirow{2}{*}{$\begin{array}{l}\text { Dwell } \\
\text { Time } \\
\text { (hour) }\end{array}$} & \multicolumn{2}{|c|}{$\begin{array}{l}\text { Bingham Model } \\
\left(\tau=\tau_{0}{ }^{B}+\eta_{p} \dot{\gamma}\right)\end{array}$} & \multicolumn{3}{|c|}{$\begin{array}{l}\text { Herschel-Bulkley Model } \\
\quad\left(\tau=\tau_{0}{ }^{H}+k(\dot{\gamma})^{n}\right)\end{array}$} & \multirow{2}{*}{$\begin{array}{c}\text { Experimental } \\
\\
\text { Yield Stress } \\
(\mathrm{Pa})\end{array}$} \\
\hline & & $\begin{array}{c}\text { Yield Stress } \\
\left(\tau_{0}{ }^{B}, \mathrm{~Pa}\right)\end{array}$ & $\begin{array}{c}\text { Consistency } \\
\text { Index } \\
\left(\eta_{p}, \mathrm{~Pa} . \mathrm{S}\right) \\
\end{array}$ & $\begin{array}{c}\text { Yield Stress } \\
\left(\tau_{0}{ }^{H}, \mathrm{~Pa}\right)\end{array}$ & $\begin{array}{c}\text { Consistency } \\
\text { Index } \\
\left(k, \mathrm{~Pa} \cdot \mathrm{S}^{\mathrm{n}}\right) \\
\end{array}$ & $\begin{array}{c}\text { Flow Behavior } \\
\text { Index } \\
(n)\end{array}$ & \\
\hline 1265 & 0 & 8.0 & 3.5 & - & - & - & 2.0 \\
\hline 1265 & 1 & 8.5 & 3.6 & - & - & - & - \\
\hline 1265 & 2 & 8.5 & 3.6 & - & - & - & - \\
\hline 1164 & 0 & 9.8 & 8.6 & - & - & - & 6.4 \\
\hline 1164 & 1 & 8.9 & 8.4 & - & - & - & - \\
\hline 1164 & 2 & 7.3 & 8.4 & - & - & - & - \\
\hline 1062 & 0 & 22.1 & 20.6 & - & - & - & - \\
\hline 1062 & 1 & 9.5 & 20.3 & - & - & - & - \\
\hline 1062 & 2 & 9.4 & 19.9 & - & - & - & - \\
\hline 1062 & 4 & 8.9 & 19.6 & - & - & - & - \\
\hline 961 & 0 & 24.6 & 61.9 & - & - & - & - \\
\hline 961 & 1 & 6.7 & 61.5 & - & - & - & - \\
\hline 961 & 2 & 5.5 & 61.2 & - & - & - & - \\
\hline 961 & 4 & 6.5 & 60.6 & - & - & - & - \\
\hline 961 & 24 & 9.8 & 59.1 & - & - & - & - \\
\hline
\end{tabular}

-Empty data field 
ORP-56295 Rev. 0

The Catholic University of America

Vitreous State Laboratory
Crystal Settling, Redox, and Properties of ORP HLW \& LAW Glasses

Final Report, VSL-09R1510-1, Rev. 0

\section{Table 2.8. Yield Stress Measurement and Analysis of the Relationship of Shear Stress vs. Shear Rate for HLW-E-SP-05.}

\begin{tabular}{|c|c|c|c|c|c|c|c|}
\hline \multirow[t]{2}{*}{$\begin{array}{l}\text { Temperature } \\
\left({ }^{\circ} \mathrm{C}\right)\end{array}$} & \multirow{2}{*}{$\begin{array}{l}\text { Dwell } \\
\text { Time } \\
\text { (hour) }\end{array}$} & \multicolumn{2}{|c|}{$\begin{array}{l}\text { Bingham Model } \\
\left(\tau=\tau_{0}{ }^{B}+\eta_{p} \dot{\gamma}\right)\end{array}$} & \multicolumn{3}{|c|}{$\begin{array}{l}\text { Herschel-Bulkley Model } \\
\quad\left(\tau=\tau_{0}{ }^{H}+k(\dot{\gamma})^{n}\right)\end{array}$} & \multirow{2}{*}{$\begin{array}{c}\text { Experimental } \\
\text { Yield Stress } \\
(\mathrm{Pa})\end{array}$} \\
\hline & & $\begin{array}{c}\text { Yield Stress } \\
\left(\tau_{0}^{B}, \mathrm{~Pa}\right)\end{array}$ & $\begin{array}{c}\text { Consistency } \\
\text { Index } \\
\left(\eta_{p}, \mathrm{~Pa} . \mathrm{S}\right) \\
\end{array}$ & $\begin{array}{c}\text { Yield } \\
\text { Stress } \\
\left(\tau_{0}^{H}, \mathrm{~Pa}\right) \\
\end{array}$ & $\begin{array}{c}\text { Consistency } \\
\text { Index } \\
\left(k, \mathrm{~Pa} . \mathrm{S}^{\mathrm{n}}\right) \\
\end{array}$ & $\begin{array}{c}\text { Flow Behavior } \\
\text { Index } \\
(n)\end{array}$ & \\
\hline 1263 & 0 & 1.6 & 2.4 & - & - & - & - \\
\hline 1263 & 1 & 1.5 & 2.2 & - & - & - & - \\
\hline 1263 & 2 & 1.0 & 2.2 & - & - & - & - \\
\hline 1162 & 0 & 0.2 & 6.2 & - & - & - & - \\
\hline 1162 & 1 & 0.3 & 6.6 & - & - & - & - \\
\hline 1162 & 2 & 0.4 & 6.6 & - & - & - & - \\
\hline 1060 & 0 & 3.7 & 19.3 & 4.3 & 19.0 & 1.00 & Failed \\
\hline 1060 & 1 & 35.5 & 28.4 & 17.7 & 42.1 & 0.89 & 179.2 \\
\hline 1060 & 2 & 39.0 & 28.4 & 22.5 & 41.0 & 0.89 & 43.4 \\
\hline 1060 & 4 & 40.1 & 28.9 & 25.0 & 40.3 & 0.90 & 37.1 \\
\hline 960 & 0 & 115.3 & 226.1 & 2.2 & 377.1 & 0.65 & 606.8 \\
\hline 960 & 1 & 146.2 & 213.5 & 72.7 & 314.3 & 0.73 & 359.2 \\
\hline 960 & 2 & 165.2 & 225.4 & 62.5 & 363.6 & 0.67 & 274.0 \\
\hline 960 & 4 & 168.4 & 223.6 & 73.3 & 352.2 & 0.69 & 247.1 \\
\hline 960 & 24 & 168.2 & 193.2 & 97.5 & 289.9 & 0.72 & 193.4 \\
\hline
\end{tabular}

-Empty data field 
Table 2.9. Yield Stress Measurement and Analysis of the Relationship of Shear Stress vs. Shear Rate for HLW-E-SP-06.

\begin{tabular}{|c|c|c|c|c|c|c|c|}
\hline \multirow{2}{*}{$\begin{array}{c}\text { Temperature } \\
\left({ }^{\circ} \mathrm{C}\right)\end{array}$} & \multirow{2}{*}{$\begin{array}{c}\text { Dwelling } \\
\text { Time (hour) }\end{array}$} & \multicolumn{2}{|c|}{$\begin{array}{c}\text { Bingham Model } \\
\left(\tau=\tau_{0}{ }^{B}+\eta_{p} \dot{\gamma}\right)\end{array}$} & \multicolumn{3}{|c|}{$\begin{array}{c}\text { Herschel-Bulkley Model } \\
\left(\tau=\tau_{0}^{H}+k(\dot{\gamma})^{n}\right)\end{array}$} & Experimental \\
\cline { 3 - 8 } & $\begin{array}{c}\text { Yield } \\
\text { Stress } \\
\left(\tau_{0}{ }^{3}, \mathrm{~Pa}\right)\end{array}$ & $\begin{array}{c}\text { Consistency } \\
\text { Index } \\
\left(\eta_{p}, \text { Pa.S }\right)\end{array}$ & $\begin{array}{c}\text { Yield } \\
\text { Stress } \\
\left(\tau_{0}^{H}, \text { Pa) }\right.\end{array}$ & $\begin{array}{c}\text { Consistency } \\
\text { Index } \\
\left(k, \text { Pa. }^{\mathrm{n}}\right)\end{array}$ & $\begin{array}{c}\text { Flow } \\
\text { Behavior } \\
\text { Index }(n)\end{array}$ & $\begin{array}{c}\text { Yield Stress } \\
(\mathrm{Pa})\end{array}$ \\
\hline 1161 & 0 & 0.8 & 3.9 & - & - & - & - \\
\hline 1161 & 1 & 1.7 & 3.7 & - & - & - & - \\
\hline 1062 & 0 & 1.7 & 9.6 & - & - & - & - \\
\hline 1062 & 1 & 1.6 & 9.7 & - & - & - & - \\
\hline 1062 & 2 & 1.5 & 9.8 & - & - & - & - \\
\hline 1062 & 4 & 1.5 & 9.9 & - & - & - & - \\
\hline 963 & 0 & 0.1 & 32.2 & - & - & - & - \\
\hline 963 & 1 & 0.6 & 32.7 & - & - & - & - \\
\hline 963 & 2 & 7.5 & 33.5 & - & - & - & - \\
\hline 963 & 4 & 20.0 & 36.3 & - & - & - & - \\
\hline 963 & 24 & 13.2 & 39.6 & - & - & - & - \\
\hline
\end{tabular}

-Empty data field 
ORP-56295 Rev. 0

The Catholic University of America

Vitreous State Laboratory
Crystal Settling, Redox, and Properties of ORP HLW \& LAW Glasses

Final Report, VSL-09R1510-1, Rev. 0

Table 2.10. Data Summary of Crystal Settling and Melt Rheology for Three HLW Glasses.

\begin{tabular}{|c|c|c|c|c|c|c|c|c|c|}
\hline $\begin{array}{c}\text { Sample } \\
\text { Name }\end{array}$ & \multicolumn{3}{|c|}{ HLW-E-ES-02 } & \multicolumn{3}{|c|}{ HLW-E-SP-05 } & \multicolumn{3}{|c|}{ HLW-E-SP-06 } \\
\hline Idling $\mathrm{T}\left({ }^{\circ} \mathrm{C}\right)$ & 1150 & 1050 & 950 & 1150 & 1050 & 950 & 1150 & 1050 & 950 \\
\hline Yield Stress & No & No & No & No & Large & $\begin{array}{l}\text { Very } \\
\text { Large }\end{array}$ & No & No & No \\
\hline $\begin{array}{c}\text { Flow } \\
\text { Behavior }\end{array}$ & Bingham & Bingham & Bingham & Bingham & $\begin{array}{c}\text { Herschel- } \\
\text { Bulkley }\end{array}$ & $\begin{array}{c}\text { Herschel- } \\
\text { Bulkley }\end{array}$ & Bingham & Bingham & Bingham \\
\hline $\begin{array}{c}\text { Crystalline } \\
\text { Phase } \\
\text { (vol\% after } \\
70 \text { hours) }\end{array}$ & $\begin{array}{c}\text { Eskolaite } \\
(1.6)\end{array}$ & $\begin{array}{c}\text { Eskolaite } \\
(1.3 \text { at } \\
1100^{\circ} \mathrm{C} \\
2.0 \text { at } \\
\left.1000^{\circ} \mathrm{C}\right) \\
\end{array}$ & $\begin{array}{c}\text { Eskolaite } \\
(2.0)\end{array}$ & $\begin{array}{l}\text { Spinel } \\
(2.9)\end{array}$ & $\begin{array}{c}\text { Spinel } \\
(4 \text { at } \\
1100 \text { and } \\
\left.1000^{\circ} \mathrm{C}\right)\end{array}$ & $\begin{array}{l}\text { Spinel } \\
(4.2)\end{array}$ & $\begin{array}{c}\text { Spinel } \\
(1.3)\end{array}$ & $\begin{array}{c}\text { Spinel } \\
(1.0 \text { at } \\
1100^{\circ} \mathrm{C} \\
1.4 \text { at } \\
\left.1000^{\circ} \mathrm{C}\right) \\
\end{array}$ & $\begin{array}{l}\text { Spinel } \\
(2.2)\end{array}$ \\
\hline $\begin{array}{c}\text { Large scale } \\
\text { crystal } \\
\text { aggregation }\end{array}$ & Extensive & Extensive & Extensive & $\begin{array}{c}\text { No } \\
(\mathrm{t}<14) \\
\text { Extensive } \\
(\mathrm{t} \geq 14)\end{array}$ & Moderate & Extensive & No & No & $\begin{array}{c}\text { No } \\
\text { (on } \\
\text { surface at } \\
\mathrm{t}=28 \text { ) }\end{array}$ \\
\hline $\begin{array}{l}\text { Crystal } \\
\text { settling }\end{array}$ & Extensive & Moderate & $\begin{array}{c}\text { No }(t<14) \\
\text { Moderate } \\
(t \geq 14)\end{array}$ & $\begin{array}{l}\text { Extensive } \\
(\mathrm{t} \geq 28)\end{array}$ & No & No & $\begin{array}{c}\text { Extensive } \\
(t \geq 14)\end{array}$ & $\begin{array}{c}\text { Moderate } \\
(t \geq 14)\end{array}$ & No \\
\hline $\begin{array}{c}\text { Dominant } \\
\text { Crystal size } \\
(\mu, \text { after } 70 \\
\text { hours })\end{array}$ & 19 & $\begin{array}{c}16 \text { at } \\
1100^{\circ} \mathrm{C} \\
17 \text { at } \\
1000^{\circ} \mathrm{C}\end{array}$ & 35 & 8 & $\begin{array}{c}4 \text { at } \\
1100^{\circ} \mathrm{C} \\
5 \text { at } \\
1000^{\circ} \mathrm{C}\end{array}$ & 5 & 10 & $\begin{array}{c}8 \text { at } \\
1100^{\circ} \mathrm{C} \\
15 \text { at } \\
1000^{\circ} \mathrm{C}\end{array}$ & 15 \\
\hline $\begin{array}{c}\text { Crystal } \\
\text { shape }\end{array}$ & $\begin{array}{l}\text { Platelet } \\
\text { /acicular }\end{array}$ & $\begin{array}{l}\text { Platelet } \\
\text { /acicular }\end{array}$ & $\begin{array}{l}\text { Platelet } \\
\text { /acicular }\end{array}$ & Cubic & Cubic & Cubic & Cubic & Cubic & Cubic \\
\hline
\end{tabular}


Table 3.1. Compositions of Glasses Used in Redox Studies.

\begin{tabular}{|c|c|c|c|c|c|c|c|c|}
\hline \multirow{3}{*}{ Oxides } & \multicolumn{2}{|c|}{ LAWB99 for AZ102 } & \multicolumn{2}{|c|}{ ORPLE12 for AZ101 } & \multicolumn{2}{|c|}{ ORPLD6 for AN102 } & \multicolumn{2}{|c|}{ ORPLA15 for AN105 } \\
\hline & \multicolumn{2}{|c|}{ DM100 Melter } & \multicolumn{2}{|c|}{ DM10 Melter } & \multicolumn{2}{|c|}{ DM10 Melter } & \multicolumn{2}{|c|}{ DM10 Melter } \\
\hline & Target & DWV-G-123B & Target & Q10-G-136D & Target & Z10-G-60C & Target & R10-G-155B \\
\hline $\mathrm{Al}_{2} \mathrm{O}_{3}$ & 10.06 & 9.46 & 7.60 & 7.21 & 10.12 & 8.71 & 9.46 & 9.47 \\
\hline $\mathrm{B}_{2} \mathrm{O}_{3}$ & 10.91 & 10.90 & 9.85 & 9.80 & 9.87 & 9.90 & 8.65 & 8.60 \\
\hline $\mathrm{CaO}$ & 10.11 & 9.72 & 10.05 & 10.18 & 7.91 & 8.28 & 3.34 & 3.61 \\
\hline $\mathrm{Cr}_{2} \mathrm{O}_{3}$ & 0.11 & 0.21 & 0.50 & 0.45 & 0.50 & 0.85 & 0.50 & 0.37 \\
\hline $\mathrm{Cs}_{2} \mathrm{O}$ spike & - & - & - & 0.19 & - & - & - & 0.11 \\
\hline $\mathrm{Fe}_{2} \mathrm{O}_{3}$ & 1.14 & 1.33 & 0.24 & 0.37 & 0.30 & 0.58 & 0.93 & 1.15 \\
\hline $\mathrm{K}_{2} \mathrm{O}$ & 0.40 & 0.58 & 0.55 & 0.60 & 0.17 & 0.22 & 0.54 & 0.58 \\
\hline $\mathrm{Li}_{2} \mathrm{O}$ & 3.52 & 3.51 & 2.50 & 2.49 & 0.00 & 0.00 & 0.00 & 0.00 \\
\hline $\mathrm{MgO}$ & 1.14 & 1.16 & 1.05 & 1.03 & 0.99 & 0.52 & 0.93 & 0.86 \\
\hline $\mathrm{Na}_{2} \mathrm{O}$ & 9.96 & 10.38 & 16.00 & 16.02 & 22.00 & 23.13 & 24.00 & 23.27 \\
\hline $\mathrm{NiO}$ & 0.00 & 0.00 & 0.00 & 0.02 & 0.04 & 0.24 & 0.00 & 0.03 \\
\hline $\mathrm{PbO}$ & 0.00 & 0.00 & 0.00 & $<0.01$ & 0.01 & 0.02 & 0.00 & 0.01 \\
\hline $\mathrm{SiO}_{2}$ & 42.73 & 42.52 & 41.41 & 41.09 & 37.33 & 36.74 & 39.50 & 39.19 \\
\hline $\mathrm{SnO}_{2}$ & - & - & - & - & - & - & 2.75 & 3.37 \\
\hline $\mathrm{TiO}_{2}$ & 0.00 & 0.25 & 0.00 & 0.16 & 0.00 & 0.16 & 0.00 & 0.10 \\
\hline $\mathrm{V}_{2} \mathrm{O}_{5}$ & 1.23 & 1.42 & 1.75 & 2.00 & 1.97 & 2.27 & - & - \\
\hline $\mathrm{ZnO}$ & 3.51 & 3.46 & 3.22 & 3.22 & 2.97 & 3.20 & 2.45 & 2.76 \\
\hline $\mathrm{ZrO}_{2}$ & 3.51 & 3.83 & 3.54 & 3.25 & 3.99 & 3.10 & 5.95 & 5.42 \\
\hline $\mathrm{Cl}$ & 0.01 & 0.01 & 0.02 & 0.03 & 0.35 & 0.31 & 0.68 & 0.42 \\
\hline $\mathrm{F}$ & 0.07 & NA & 0.20 & NA & 0.18 & $\mathrm{NA}$ & 0.00 & $\mathrm{NA}$ \\
\hline I spike & 0.10 & 0.03 & 0.00 & $<0.01$ & 0.00 & 0.00 & 0.10 & 0.09 \\
\hline $\mathrm{P}_{2} \mathrm{O}_{5}$ & 0.03 & 0.08 & 0.12 & 0.18 & 0.30 & 0.39 & 0.00 & 0.02 \\
\hline $\mathrm{SO}_{3}$ & 1.50 & 1.16 & 1.25 & 1.52 & 1.01 & 1.26 & 0.18 & 0.52 \\
\hline SUM & 100.0 & 100.0 & 100.0 & 100.0 & 100.0 & 100.0 & 100.0 & 100.0 \\
\hline
\end{tabular}

- Empty data field 
Table 3.2. Sample Identifications and Results of Redox Studies.

\begin{tabular}{|c|c|c|c|c|c|c|}
\hline Sample ID & $\begin{array}{c}\text { Bubbling } \\
\text { time (min) }\end{array}$ & $\begin{array}{l}\text { Cumulative } \\
\text { time (min) }\end{array}$ & $\begin{array}{c}\mathrm{Fe}^{2+} / \\
\left(\mathrm{Fe}^{2+}+\mathrm{Fe}^{3+}\right)\end{array}$ & $\begin{array}{c}\mathrm{Sn}^{2+} / \\
\left(\mathrm{Sn}^{2+}+\mathrm{Sn}^{4+}\right)\end{array}$ & $\begin{array}{c}\mathrm{V}^{4+} / \\
\left(\mathrm{V}^{4+}+\mathrm{V}^{5+}\right)\end{array}$ & $\begin{array}{c}\mathrm{Cr}^{3+} / \\
\left(\mathrm{Cr}^{3+}+\mathrm{Cr}^{6+}\right)\end{array}$ \\
\hline \multicolumn{7}{|c|}{ Glass: R10-G-155B (2.75 wt $\% \mathrm{SnO}_{2}, 0.93 \mathrm{wt} \% \mathrm{Fe}_{2} \mathrm{O}_{3}, 0.50 \mathrm{wt} \% \mathrm{Cr}_{2} \mathrm{O}_{3}$; see Table 4.1 for full composition) } \\
\hline R10-G-155B & 0 & 0 & $\leq 0.03$ & & \multirow{9}{*}{$\begin{array}{c}\text { No } \\
\mathrm{V} \\
\text { in this } \\
\text { sample }\end{array}$} & - \\
\hline R10G155BRE1 & 30 & 30 & - & & & - \\
\hline R10G155BRE2 & 60 & 90 & - & & & - \\
\hline R10G155BRE3 & 60 & 150 & - & & & - \\
\hline R10G155BRE4 & 60 & 210 & - & & & - \\
\hline R10G155BRE5 & 60 & 270 & - & & & - \\
\hline R10G155BRE6 & 60 & 330 & 0.67 & & & - \\
\hline R10G155BRE7 & 90 & 420 & - & & & - \\
\hline R10G155BRE8 & 90 & 510 & 0.68 & 0.03 & & - \\
\hline \multicolumn{7}{|c|}{ Glass: $\mathrm{Z10}-\mathrm{G}-60 \mathrm{C}\left(1.97 \% \mathrm{~V}_{2} \mathrm{O}_{5}, 0.30 \mathrm{wt} \% \mathrm{Fe}_{2} \mathrm{O}_{3}, 0.50 \mathrm{wt} \% \mathrm{Cr}_{2} \mathrm{O}_{3}\right.$; see Table 3.1 for full composition) } \\
\hline Z10-G-60C & 0 & 0 & \multirow{12}{*}{$\begin{array}{c}\text { No measurable } \\
\text { redox }\end{array}$} & \multirow{12}{*}{$\begin{array}{c}\text { No } \\
\text { Sn } \\
\text { in this } \\
\text { sample }\end{array}$} & 0.09 & 0.16 \\
\hline Z10G60CRE1 & 30 & 30 & & & 0.12 & 0.41 \\
\hline Z10G60CRE2 & 30 & 60 & & & 0.09 & 0.48 \\
\hline Z10G60CRE3 & 30 & 90 & & & - & - \\
\hline Z10G60CRE4 & 30 & 120 & & & 0.13 & 0.60 \\
\hline Z10G60CRE5 & 30 & 150 & & & - & - \\
\hline Z10G60CRE6 & 30 & 180 & & & 0.12 & 0.66 \\
\hline Z10G60CRE7 & 30 & 210 & & & 0.14 & 0.67 \\
\hline \multicolumn{3}{|c|}{ Bubbling with a new parent glass } & & & & \\
\hline Z10G60CRE8 & 210 & 210 & & & 0.10 & 0.63 \\
\hline Z10G60CRE9 & 90 & 300 & & & - & - \\
\hline Z10G60CRE10 & 90 & 390 & & & 0.08 & 0.58 \\
\hline \multicolumn{7}{|c|}{ Glass: DWV-G-123B (1.23\% $\mathrm{V}_{2} \mathrm{O}_{5}, 1.14 \mathrm{wt} \% \mathrm{Fe}_{2} \mathrm{O}_{3}, 0.11 \mathrm{wt} \% \mathrm{Cr}_{2} \mathrm{O}_{3}$; see Table 3.1 for full composition) } \\
\hline DWV-G-123B & 0 & 0 & - & \multirow{12}{*}{$\begin{array}{c}\text { No } \\
\text { Sn } \\
\text { in this } \\
\text { sample }\end{array}$} & 0.15 & 0.85 \\
\hline DWVG123BRE1 & 30 & 30 & - & & - & - \\
\hline DWVG123BRE2 & 30 & 60 & 0.47 & & 0.34 & 1.00 \\
\hline DWVG123BRE3 & 30 & 90 & - & & - & - \\
\hline DWVG123BRE4 & 30 & 120 & - & & 0.26 & 1.00 \\
\hline DWVG123BRE5 & 30 & 150 & - & & - & - \\
\hline DWVG123BRE6 & 30 & 180 & - & & 0.16 & 1.00 \\
\hline DWVG123BRE7 & 30 & 210 & - & & - & - \\
\hline \multicolumn{3}{|c|}{ Bubbling with a new parent glass } & - & & & \\
\hline DWVG123BRE8 & 210 & 210 & - & & 0.16 & 1.00 \\
\hline DWVG123BRE9 & 90 & 300 & - & & - & - \\
\hline DWVG123BRE10 & 90 & 390 & 0.31 & & 0.21 & 1.00 \\
\hline \multicolumn{7}{|c|}{ Glass: Q10-G-136D $\left(1.75 \% \mathrm{~V}_{2} \mathrm{O}_{5}, 0.24 \mathrm{wt} \% \mathrm{Fe}_{2} \mathrm{O}_{3}, 0.50 \mathrm{wt} \% \mathrm{Cr}_{2} \mathrm{O}_{3}\right.$; see Table 3.1 for full composition) } \\
\hline Q10-G-136D & 0 & 0 & \multirow{9}{*}{$\begin{array}{c}\text { No measurable } \\
\text { redox }\end{array}$} & \multirow{9}{*}{$\begin{array}{c}\text { No } \\
\text { Sn } \\
\text { in this } \\
\text { sample }\end{array}$} & 0.08 & 0.34 \\
\hline Q10G136DRE1 & 30 & 30 & & & 0.13 & 0.63 \\
\hline Q10G136DRE2 & 30 & 60 & & & 0.06 & 0.75 \\
\hline Q10G136DRE3 & 30 & 90 & & & 0.07 & 0.76 \\
\hline Q10G136DRE4 & 60 & 150 & & & 0.12 & 0.90 \\
\hline Q10G136DRE5 & 60 & 210 & & & - & - \\
\hline Q10G136DRE6 & 60 & 270 & & & 0.14 & 0.92 \\
\hline Q10G136DRE7 & 60 & 330 & & & - & - \\
\hline Q10G136DRE8 & 60 & 390 & & & 0.13 & 0.95 \\
\hline
\end{tabular}


ORP-56295 Rev. 0

The Catholic University of America Vitreous State Laboratory
Crystal Settling, Redox, and Properties of ORP HLW \& LAW Glasses

Final Report, VSL-09R1510-1, Rev. 0

Table 4.1. XRF Analyzed Compositions of Four Simulated Waste Glasses (wt \%).

\begin{tabular}{|c|c|c|c|c|}
\hline Sample name & WTP-C106 & BLM-G-139A & 12U-G-86A & Y10-G-146B \\
\hline Glass Name & WTP-C106 & HLW-E-A127 & LAWA44 & ORPLA20 \\
\hline $\mathrm{Al}_{2} \mathrm{O}_{3}$ & 4.89 & 22.08 & 6.40 & 6.57 \\
\hline $\mathrm{B}_{2} \mathrm{O}_{3}$ & 10.27 & 16.17 & 8.98 & 8.80 \\
\hline $\mathrm{BaO}$ & 0.07 & 0.36 & - & - \\
\hline $\mathrm{Bi}_{2} \mathrm{O}_{3}$ & 0.46 & 1.2 & - & - \\
\hline $\mathrm{CaO}$ & 0.10 & 5.66 & 1.94 & 3.55 \\
\hline $\mathrm{CdO}$ & - & - & 0.13 & \\
\hline $\mathrm{Ce}_{2} \mathrm{O}_{3}$ & 0.10 & - & - & 0.01 \\
\hline $\mathrm{Cl}$ & - & 0.01 & 0.41 & 0.50 \\
\hline $\mathrm{CoO}$ & - & 0.00 & - & 0.00 \\
\hline $\mathrm{Co}_{3} \mathrm{O}_{4}$ & - & - & 0.00 & - \\
\hline $\mathrm{Cr}_{2} \mathrm{O}_{3}$ & 0.22 & 0.51 & 0.08 & 0.72 \\
\hline $\mathrm{Cs}_{2} \mathrm{O}$ & - & - & 0.14 & - \\
\hline $\mathrm{Er}_{2} \mathrm{O}_{3}$ & - & 0.01 & - & - \\
\hline $\mathrm{F}$ & - & 0.4 & - & - \\
\hline $\mathrm{Fe}_{2} \mathrm{O}_{3}$ & 14.03 & 5.86 & 7.27 & 0.34 \\
\hline $\mathrm{Ga}_{2} \mathrm{O}_{3}$ & - & 0.00 & - & - \\
\hline $\mathrm{H}_{\mathrm{f}} \mathrm{O}_{2}$ & - & 0.01 & 0.06 & 0.13 \\
\hline I & - & - & 0.03 & 0.10 \\
\hline $\mathrm{In}_{2} \mathrm{O}_{3}$ & - & - & - & 0.01 \\
\hline $\mathrm{K}_{2} \mathrm{O}$ & - & 0.42 & 0.57 & 0.55 \\
\hline $\mathrm{La}_{2} \mathrm{O}_{3}$ & 0.08 & - & - & 0.02 \\
\hline $\mathrm{Li}_{2} \mathrm{O}$ & 2.64 & 3.68 & - & - \\
\hline $\mathrm{MgO}$ & 0.14 & 0.36 & 1.84 & 1 \\
\hline $\mathrm{MnO}$ & 2.82 & 0.03 & 0.01 & 0.01 \\
\hline $\mathrm{MoO}_{3}$ & - & - & - & 0.01 \\
\hline $\mathrm{Na}_{2} \mathrm{O}$ & 12.55 & 9.55 & 19.04 & 22.54 \\
\hline $\mathrm{Nd}_{2} \mathrm{O}_{3}$ & - & 0.01 & - & 0.01 \\
\hline $\mathrm{NiO}$ & 0.41 & 0.31 & 0.00 & 0.09 \\
\hline $\mathrm{P}_{2} \mathrm{O}_{5}$ & 0.56 & 1.1 & 0.09 & 0.03 \\
\hline $\mathrm{PbO}$ & 0.54 & 0.36 & - & 0.01 \\
\hline $\mathrm{Rb}_{2} \mathrm{O}$ & - & 0.00 & - & - \\
\hline $\mathrm{SO}_{3}$ & 0.19 & 0.14 & 0.23 & 0.63 \\
\hline $\mathrm{SeO}_{2}$ & - & - & 0.06 & 0.01 \\
\hline $\mathrm{SiO}_{2}$ & 47.75 & 31.12 & 45.35 & 42.48 \\
\hline $\mathrm{Sm}_{2} \mathrm{O}_{3}$ & - & - & 0.01 & - \\
\hline $\mathrm{SnO}_{2}$ & 0.06 & 0.01 & 0.01 & 3.21 \\
\hline $\mathrm{SrO}$ & 0.17 & - & - & - \\
\hline $\mathrm{Tb}_{4} \mathrm{O}_{7}$ & - & - & 0.01 & - \\
\hline $\mathrm{TiO}_{2}$ & - & 0.05 & 2.15 & 0.05 \\
\hline $\mathrm{V}_{2} \mathrm{O}_{5}$ & - & - & - & 0.01 \\
\hline $\mathrm{Y}_{2} \mathrm{O}_{3}$ & - & - & 0.01 & 0.012 \\
\hline $\mathrm{ZnO}$ & 1.03 & 0.09 & 2.936 & 2.9 \\
\hline $\mathrm{ZrO}_{2}$ & 0.98 & 0.47 & 3.27 & 5.69 \\
\hline Total & 100.1 & 99.98 & 101.0 & 100.0 \\
\hline g.atom & 20.78 & 19.28 & 20.84 & 21.62 \\
\hline $\begin{array}{l}\text { Room temperature } \\
\text { Density }\left(\mathrm{g} / \mathrm{cm}^{3}\right)\end{array}$ & 2.694 & 2.567 & 2.667 & 2.683 \\
\hline $\mathrm{Tg},{ }^{\circ} \mathrm{C}$ & 466 & 487 & 519 & 530 \\
\hline
\end{tabular}

\section{- Empty data field}


Table 4.2. Specific Heat of Four Simulated Waste Glasses/Melts During Heating $\left(5^{\circ} \mathrm{C} / \mathrm{minute}\right.$ in air $)$.

\begin{tabular}{|c|c|c|c|c|c|c|c|}
\hline \multicolumn{2}{|r|}{ WTP-C106 } & \multicolumn{2}{|c|}{ HLW-E-A127 } & \multicolumn{2}{|r|}{ LAWA44 } & \multicolumn{2}{|c|}{ ORPLA20 } \\
\hline $\begin{array}{c}\mathrm{T} \\
\left({ }^{\circ} \mathrm{C}\right)\end{array}$ & $\mathrm{Cp}(\mathrm{J} / \mathrm{g}$-atom $\mathrm{K})$ & $\begin{array}{c}\mathrm{T} \\
\left({ }^{\circ} \mathrm{C}\right)\end{array}$ & $\mathrm{Cp}(\mathrm{J} / \mathrm{g}$-atom $\mathrm{K})$ & $\begin{array}{c}\mathrm{T} \\
\left({ }^{\circ} \mathrm{C}\right)\end{array}$ & $\mathrm{Cp}(\mathrm{J} / \mathrm{g}$-atom $\mathrm{K})$ & $\mathrm{T}\left({ }^{\circ} \mathrm{C}\right)$ & $\mathrm{Cp}(\mathrm{J} / \mathrm{g}$-atom $\mathrm{K})$ \\
\hline 330 & 21.7 & 330 & 19.6 & 330 & 21.0 & 330 & 20.8 \\
\hline 340 & 21.8 & 340 & 19.8 & 340 & 21.0 & 340 & 20.9 \\
\hline 350 & 21.7 & 350 & 20.0 & 350 & 21.1 & 350 & 20.8 \\
\hline 360 & 21.6 & 360 & 20.0 & 360 & 20.9 & 360 & 20.7 \\
\hline 370 & 21.7 & 370 & 20.0 & 370 & 20.8 & 370 & 20.8 \\
\hline 380 & 21.5 & 380 & 20.1 & 380 & 20.5 & 380 & 20.3 \\
\hline 390 & 21.4 & 390 & 20.3 & 390 & 20.5 & 390 & 20.2 \\
\hline 400 & 21.7 & 400 & 20.6 & 400 & 20.7 & 400 & 20.6 \\
\hline 410 & 21.8 & 410 & 20.6 & 410 & 20.8 & 410 & 20.6 \\
\hline 420 & 21.9 & 420 & 20.5 & 420 & 21.0 & 420 & 20.7 \\
\hline 430 & 22.0 & 430 & 20.8 & 430 & 21.1 & 430 & 20.9 \\
\hline 440 & 22.2 & 440 & 20.8 & 440 & 21.1 & 440 & 20.9 \\
\hline 450 & 22.6 & 450 & 21.0 & 450 & 21.2 & 450 & 21.0 \\
\hline & & & & & & & \\
\hline 600 & 30.5 & 600 & 29.7 & 600 & 30.1 & 600 & 29.6 \\
\hline 610 & 30.3 & & & 610 & 30.0 & 610 & 29.3 \\
\hline 620 & 30.3 & & & 620 & 29.9 & 620 & 29.2 \\
\hline 630 & 30.2 & & & 630 & 29.8 & 630 & 29.2 \\
\hline 640 & 30.1 & & & 640 & 29.7 & 640 & 29.1 \\
\hline 650 & 30.2 & & & 650 & 29.7 & 650 & 29.1 \\
\hline 660 & 30.0 & & & 660 & 29.7 & 660 & 29.0 \\
\hline 670 & 29.9 & & & 670 & 29.5 & 670 & 28.9 \\
\hline 680 & 29.9 & & & 680 & 29.3 & 680 & 28.9 \\
\hline 690 & 29.8 & & & 690 & 29.3 & 690 & 29.0 \\
\hline 700 & 29.7 & & & 700 & 29.2 & 700 & 28.8 \\
\hline 710 & 29.6 & & & 710 & 29.1 & 710 & 28.8 \\
\hline 720 & 29.6 & & & 720 & 29.0 & 720 & 28.8 \\
\hline 730 & 29.5 & & & 730 & 28.9 & 730 & 28.6 \\
\hline 740 & 29.5 & & & 740 & 28.8 & 740 & 28.7 \\
\hline 750 & 29.4 & & & 750 & 28.8 & 750 & 28.8 \\
\hline 760 & 29.3 & & & 760 & 28.8 & 760 & 28.7 \\
\hline 770 & 29.3 & & & 770 & 28.7 & 770 & 28.7 \\
\hline 780 & 29.2 & & & 780 & 28.6 & 780 & 28.7 \\
\hline 790 & 29.0 & & & 790 & 28.4 & 790 & 28.5 \\
\hline 800 & 29.0 & & & 800 & 28.3 & 800 & 28.5 \\
\hline 810 & 29.0 & & & 810 & 28.2 & 810 & 28.5 \\
\hline 820 & 28.9 & & & 820 & 28.1 & 820 & 28.4 \\
\hline 830 & 28.8 & & & 830 & 27.9 & 830 & 28.2 \\
\hline 840 & 28.8 & & & 840 & 27.9 & 840 & 28.2 \\
\hline 850 & 28.6 & & & 850 & 27.7 & 850 & 27.9 \\
\hline 860 & 28.6 & & & 860 & 27.6 & 860 & 27.9 \\
\hline 870 & 28.7 & & & 870 & 27.5 & 870 & 28.0 \\
\hline
\end{tabular}


Table 4.2. Specific Heat of Four Simulated Waste Glasses/Melts During Heating $\left(5^{\circ} \mathrm{C} /\right.$ minute in air) (continued).

\begin{tabular}{|c|c|c|c|c|c|c|c|}
\hline \multicolumn{2}{|c|}{ WTP-C106 } & \multicolumn{2}{|c|}{ HLW-E-A127 } & \multicolumn{2}{|r|}{ LAWA44 } & \multicolumn{2}{|c|}{ ORPLA20 } \\
\hline $\begin{array}{c}\mathrm{T} \\
\left({ }^{\circ} \mathrm{C}\right) \\
\end{array}$ & $\mathrm{Cp}(\mathrm{J} / \mathrm{g}$-atom $\mathrm{K})$ & $\mathrm{T}\left({ }^{\circ} \mathrm{C}\right)$ & $\mathrm{Cp}(\mathrm{J} / \mathrm{g}$-atom $\mathrm{K})$ & $\begin{array}{c}\mathrm{T} \\
\left({ }^{\circ} \mathrm{C}\right)\end{array}$ & $\mathrm{Cp}(\mathrm{J} / \mathrm{g}$-atom $\mathrm{K})$ & $\mathrm{T}\left({ }^{\circ} \mathrm{C}\right)$ & $\mathrm{Cp}(\mathrm{J} / \mathrm{g}$-atom $\mathrm{K})$ \\
\hline 880 & 28.6 & & & 880 & 27.4 & 880 & 28.0 \\
\hline 890 & 28.6 & & & 890 & 27.3 & 890 & 27.9 \\
\hline 900 & 28.6 & & & 900 & 27.1 & 900 & 27.8 \\
\hline 910 & 29.0 & & & 910 & 27.0 & 910 & 27.8 \\
\hline 920 & 29.3 & & & 920 & 27.0 & 920 & 27.7 \\
\hline 930 & 29.7 & & & 930 & 27.1 & 930 & 27.8 \\
\hline 940 & 30.0 & & & 940 & 27.3 & 940 & 28.0 \\
\hline 950 & 30.2 & & & 950 & 27.1 & 950 & 28.0 \\
\hline 960 & 30.5 & & & 960 & 27.1 & 960 & 28.0 \\
\hline 970 & 30.8 & & & 970 & 27.2 & 970 & 28.0 \\
\hline 980 & 31.1 & & & 980 & 27.2 & 980 & 28.1 \\
\hline 990 & 31.2 & & & 990 & 27.3 & 990 & 28.1 \\
\hline 1000 & 31.4 & & & 1000 & 27.4 & 1000 & 28.2 \\
\hline 1010 & 31.1 & & & 1010 & 27.4 & 1010 & 28.0 \\
\hline 1020 & 31.0 & & & 1020 & 27.5 & 1020 & 28.1 \\
\hline 1030 & 30.7 & & & 1030 & 27.3 & 1030 & 27.9 \\
\hline 1040 & 30.5 & & & 1040 & 27.1 & 1040 & 27.8 \\
\hline 1050 & 30.0 & & & 1050 & 26.9 & 1050 & 27.5 \\
\hline 1060 & 29.6 & & & 1060 & 26.8 & 1060 & 27.4 \\
\hline 1070 & 29.3 & 1070 & 29.0 & 1070 & 26.6 & 1070 & 27.2 \\
\hline
\end{tabular}


Table 4.3. Density of Four Simulated Waste Glass Melts $\left(\mathrm{g} / \mathrm{cm}^{3}\right)$. "Big" and "Small” indicate measurements using larger and smaller bobs, respectively.

\begin{tabular}{|c|c|c|c|c|c|c|}
\hline Glass & Temperature $\left({ }^{\circ} \mathrm{C}\right)$ & 800 & 900 & 1000 & 1100 & 1150 \\
\hline \multirow{4}{*}{$\begin{array}{l}8 \\
0 \\
0 \\
1 \\
0 \\
\vdots \\
3\end{array}$} & Big Bob & 2.543 & 2.499 & 2.469 & 2.442 & 2.429 \\
\hline & Small Bob & 2.539 & 2.504 & 2.470 & 2.430 & 2.421 \\
\hline & Average & 2.541 & 2.502 & 2.469 & 2.436 & 2.425 \\
\hline & Standard Deviation & 0.003 & 0.004 & 0.001 & 0.009 & 0.006 \\
\hline \multirow{5}{*}{ 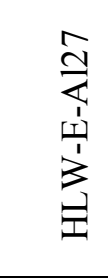 } & Big Bob-1 & 2.436 & 2.409 & 2.387 & 2.375 & 2.366 \\
\hline & Big Bob-3 & 2.422 & 2.400 & 2.385 & 2.376 & 2.366 \\
\hline & Small Bob & & 2.390 & 2.380 & 2.371 & 2.367 \\
\hline & Average & 2.429 & 2.400 & 2.384 & 2.374 & 2.366 \\
\hline & Standard Deviation & 0.010 & 0.009 & 0.004 & 0.003 & 0.001 \\
\hline \multirow{4}{*}{ 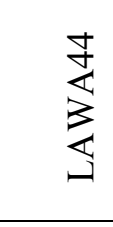 } & Big Bob & 2.522 & 2.470 & 2.447 & 2.420 & 2.409 \\
\hline & Small Bob & 2.502 & 2.476 & 2.453 & 2.423 & 2.415 \\
\hline & Average & 2.512 & 2.473 & 2.450 & 2.422 & 2.412 \\
\hline & Standard Deviation & 0.014 & 0.004 & 0.005 & 0.003 & 0.004 \\
\hline \multirow{4}{*}{ 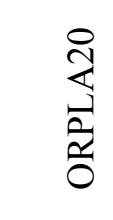 } & Big Bob & 2.540 & 2.503 & 2.475 & 2.448 & 2.434 \\
\hline & Small Bob & 2.530 & 2.505 & 2.480 & 2.454 & 2.439 \\
\hline & Average & 2.535 & 2.504 & 2.478 & 2.451 & 2.437 \\
\hline & Standard Deviation & 0.007 & 0.002 & 0.004 & 0.004 & 0.004 \\
\hline
\end{tabular}


ORP-56295 Rev. 0

The Catholic University of America

Vitreous State Laboratory
Crystal Settling, Redox, and Properties of ORP HLW \& LAW Glasses

Final Report, VSL-09R1510-1, Rev. 0

Table 4.4. Thermal Diffusivity of Four Simulated Waste Glass Melts.

\begin{tabular}{|c|c|c|c|c|c|c|c|c|c|c|c|c|c|}
\hline \multirow{2}{*}{$\frac{n}{0}$} & \multirow{2}{*}{$\begin{array}{c}\begin{array}{c}\text { Temperature } \\
\left({ }^{\circ} \mathrm{C}\right)\end{array} \\
\text { PERIOD } \\
\text { (minute) }\end{array}$} & \multicolumn{2}{|c|}{700} & \multicolumn{2}{|c|}{800} & \multicolumn{2}{|c|}{900} & \multicolumn{2}{|c|}{1000} & \multicolumn{2}{|c|}{1100} & \multicolumn{2}{|c|}{1150} \\
\hline & & 30 & 60 & 30 & 60 & 30 & 60 & 30 & 60 & 30 & 60 & 30 & 60 \\
\hline \multirow{3}{*}{$\begin{array}{l}8 \\
0 \\
0 \\
1 \\
1 \\
1 \\
3\end{array}$} & $\begin{array}{c}\text { Thermal } \\
\text { Diffusivity } \\
\left(\mathrm{cm}^{2} / \mathrm{s}\right)\end{array}$ & 0.0032 & 0.0033 & 0.0035 & 0.0035 & 0.0043 & 0.0040 & 0.0055 & 0.0054 & 0.0104 & 0.0098 & 0.0142 & 0.0134 \\
\hline & Average & \multicolumn{2}{|c|}{0.0033} & \multicolumn{2}{|c|}{0.0035} & \multicolumn{2}{|c|}{0.0041} & \multicolumn{2}{|c|}{0.0055} & \multicolumn{2}{|c|}{0.0101} & \multicolumn{2}{|c|}{0.0138} \\
\hline & $\begin{array}{c}\text { Standard } \\
\text { Deviation }\end{array}$ & \multicolumn{2}{|c|}{0.0000} & \multicolumn{2}{|c|}{0.0000} & \multicolumn{2}{|c|}{0.0003} & \multicolumn{2}{|c|}{0.0001} & \multicolumn{2}{|c|}{0.0005} & \multicolumn{2}{|c|}{0.0006} \\
\hline \multirow{3}{*}{ 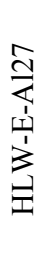 } & $\begin{array}{c}\text { Thermal } \\
\text { Diffusivity } \\
\left(\mathrm{cm}^{2} / \mathrm{s}\right)\end{array}$ & 0.0039 & 0.0039 & 0.0041 & 0.0039 & 0.0041 & 0.0042 & 0.0062 & 0.0065 & 0.0107 & 0.0125 & 0.0159 & 0.0163 \\
\hline & Average & \multicolumn{2}{|c|}{0.0039} & \multicolumn{2}{|c|}{0.0040} & \multicolumn{2}{|c|}{0.0042} & \multicolumn{2}{|c|}{0.0064} & \multicolumn{2}{|c|}{0.0116} & \multicolumn{2}{|c|}{0.0161} \\
\hline & $\begin{array}{l}\text { Standard } \\
\text { Deviation }\end{array}$ & \multicolumn{2}{|c|}{0.0000} & \multicolumn{2}{|c|}{0.0002} & \multicolumn{2}{|c|}{0.0001} & \multicolumn{2}{|c|}{0.0002} & \multicolumn{2}{|c|}{0.0013} & \multicolumn{2}{|c|}{0.0003} \\
\hline \multirow{3}{*}{ 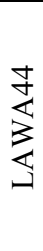 } & $\begin{array}{c}\text { Thermal } \\
\text { Diffusivity } \\
\left(\mathrm{cm}^{2} / \mathrm{s}\right)\end{array}$ & 0.0032 & 0.0030 & 0.0033 & 0.0031 & 0.0038 & 0.0035 & 0.0046 & 0.0041 & 0.0055 & 0.0047 & 0.0059 & 0.0045 \\
\hline & Average & & & & 32 & 0.0 & 36 & & 43 & & & & 52 \\
\hline & $\begin{array}{c}\text { Standard } \\
\text { Deviation }\end{array}$ & & & & 01 & & 02 & & 004 & & & & 10 \\
\hline ¿ & $\begin{array}{c}\text { Thermal } \\
\text { Diffusivity } \\
\left(\mathrm{cm}^{2} / \mathrm{s}\right)\end{array}$ & 0.0076 & 0.0079 & 0.0105 & 0.0107 & 0.0111 & 0.0109 & 0.0132 & 0.0136 & 0.0176 & 0.0180 & 0.0198 & 0.0187 \\
\hline 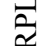 & Average & & & & 106 & & 10 & & 134 & & & & 192 \\
\hline 0 & $\begin{array}{c}\text { Standard } \\
\text { Deviation }\end{array}$ & & & & 001 & & 001 & & 003 & & & & 008 \\
\hline
\end{tabular}


Table 4.5. Thermal Conductivity of Four Simulated Waste Glass Melts. Values are listed in both $\mathrm{J} /(\mathrm{s.cm} . \mathrm{K})$ and $\mathrm{Cal} /(\mathrm{s.cm} . \mathrm{K})$ for convenience. The values of specific heat, density, and thermal diffusivity used in the calculation are listed in the same row.

\begin{tabular}{|c|c|c|c|c|c|c|}
\hline \multirow{6}{*}{ 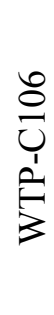 } & $\mathrm{T}\left({ }^{\circ} \mathrm{C}\right)$ & $\begin{array}{c}\mathrm{Cp} \\
\mathrm{J} / \mathrm{g} . \mathrm{K}\end{array}$ & $\begin{array}{l}\text { Density } \\
\left(\mathrm{g} / \mathrm{cm}^{3}\right)\end{array}$ & $\begin{array}{l}\text { Thermal diffusivity } \\
\left(\mathrm{cm}^{2} / \mathrm{s}\right)\end{array}$ & $\begin{array}{c}\text { Thermal conductivity } \\
(\mathrm{J} /(\mathrm{s} . \mathrm{cm} . \mathrm{K}))\end{array}$ & $\begin{array}{l}\text { Thermal conductivity } \\
(\mathrm{Cal} /(\mathrm{s} . \mathrm{cm} . \mathrm{K})\end{array}$ \\
\hline & 800 & 1.397 & 2.541 & $3.48 \mathrm{E}-03$ & $1.235 \mathrm{E}-02$ & $2.953 \mathrm{E}-03$ \\
\hline & 900 & 1.378 & 2.502 & $4.14 \mathrm{E}-03$ & $1.429 \mathrm{E}-02$ & $3.415 \mathrm{E}-03$ \\
\hline & 1000 & 1.509 & 2.469 & $5.46 \mathrm{E}-03$ & $2.034 \mathrm{E}-02$ & $4.862 \mathrm{E}-03$ \\
\hline & 1100 & 1.411 & 2.436 & $1.01 \mathrm{E}-02$ & $3.468 \mathrm{E}-02$ & $8.290 \mathrm{E}-03$ \\
\hline & 1150 & 1.411 & 2.425 & $1.38 \mathrm{E}-02$ & $4.733 \mathrm{E}-02$ & $1.131 \mathrm{E}-02$ \\
\hline \multirow{5}{*}{ 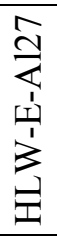 } & 800 & 1.502 & 2.429 & $4.02 \mathrm{E}-03$ & $1.465 \mathrm{E}-02$ & $3.500 \mathrm{E}-03$ \\
\hline & 900 & 1.502 & 2.400 & $4.20 \mathrm{E}-03$ & $1.513 \mathrm{E}-02$ & $3.616 \mathrm{E}-03$ \\
\hline & 1000 & 1.502 & 2.384 & $6.39 \mathrm{E}-03$ & $2.288 \mathrm{E}-02$ & $5.468 \mathrm{E}-03$ \\
\hline & 1100 & 1.502 & 2.374 & $1.16 \mathrm{E}-02$ & $4.126 \mathrm{E}-02$ & $9.860 \mathrm{E}-03$ \\
\hline & 1150 & 1.502 & 2.366 & $1.61 \mathrm{E}-02$ & $5.725 \mathrm{E}-02$ & $1.368 \mathrm{E}-02$ \\
\hline \multirow{5}{*}{ 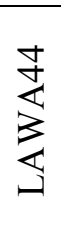 } & 800 & 1.356 & 2.512 & $3.21 \mathrm{E}-03$ & $1.092 \mathrm{E}-02$ & $2.609 \mathrm{E}-03$ \\
\hline & 900 & 1.299 & 2.473 & $3.64 \mathrm{E}-03$ & $1.168 \mathrm{E}-02$ & $2.791 \mathrm{E}-03$ \\
\hline & 1000 & 1.316 & 2.450 & $4.31 \mathrm{E}-03$ & $1.389 \mathrm{E}-02$ & $3.320 \mathrm{E}-03$ \\
\hline & 1100 & 1.276 & 2.422 & $5.07 \mathrm{E}-03$ & $1.565 \mathrm{E}-02$ & $3.741 \mathrm{E}-03$ \\
\hline & 1150 & 1.276 & 2.412 & $5.21 \mathrm{E}-03$ & $1.602 \mathrm{E}-02$ & $3.829 \mathrm{E}-03$ \\
\hline \multirow{5}{*}{ 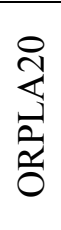 } & 800 & 1.319 & 2.535 & $1.06 \mathrm{E}-02$ & $3.530 \mathrm{E}-02$ & $8.436 \mathrm{E}-03$ \\
\hline & 900 & 1.285 & 2.504 & $1.10 \mathrm{E}-02$ & $3.539 \mathrm{E}-02$ & $8.458 \mathrm{E}-03$ \\
\hline & 1000 & 1.303 & 2.478 & $1.34 \mathrm{E}-02$ & $4.325 \mathrm{E}-02$ & $1.034 \mathrm{E}-02$ \\
\hline & 1100 & 1.303 & 2.451 & $1.78 \mathrm{E}-02$ & $5.681 \mathrm{E}-02$ & $1.358 \mathrm{E}-02$ \\
\hline & 1150 & 1.303 & 2.437 & $1.92 \mathrm{E}-02$ & $6.099 \mathrm{E}-02$ & $1.458 \mathrm{E}-02$ \\
\hline
\end{tabular}




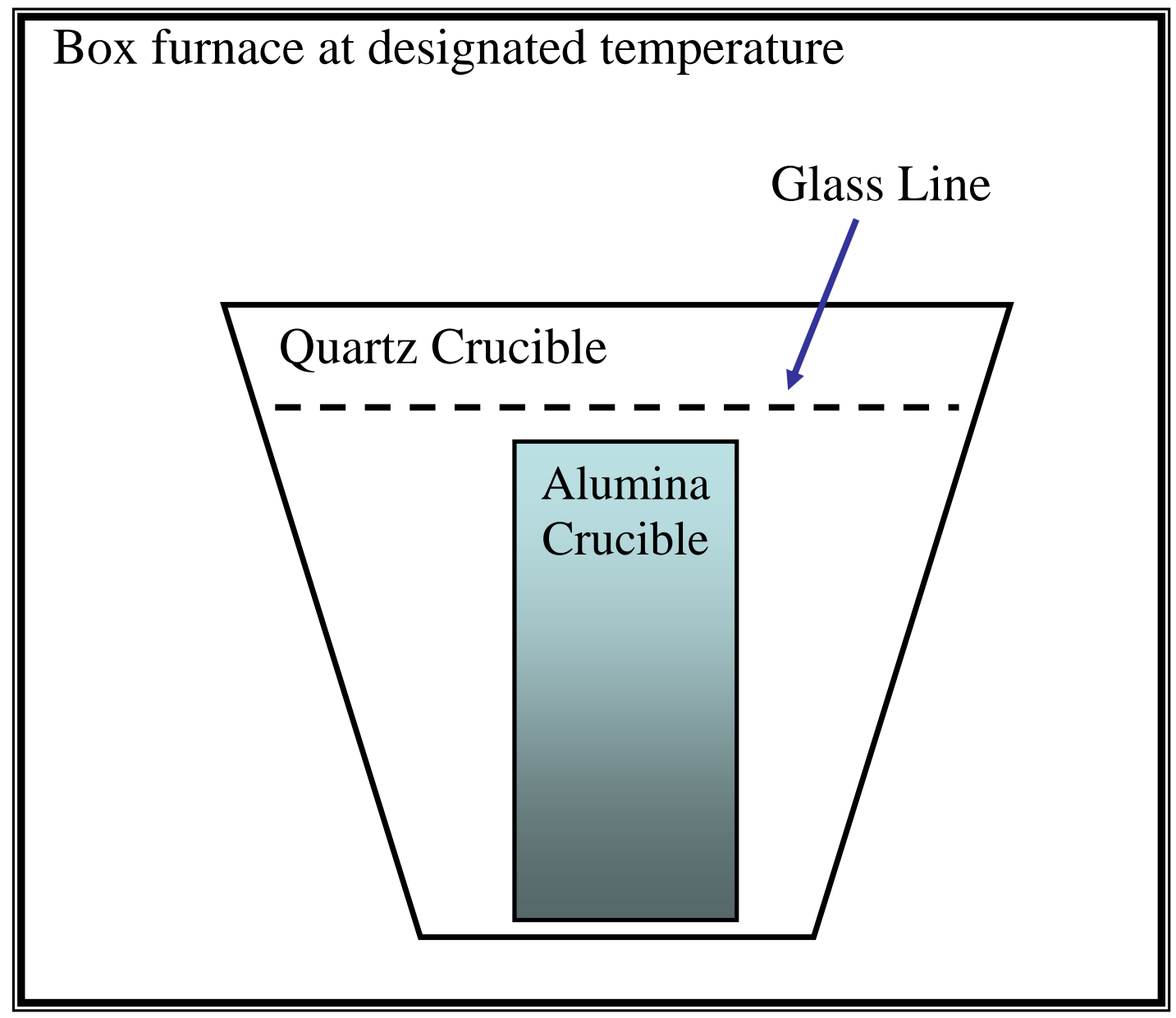

Figure 2.1. Schematic drawing of double crucible set up for crystal settling experiment. 

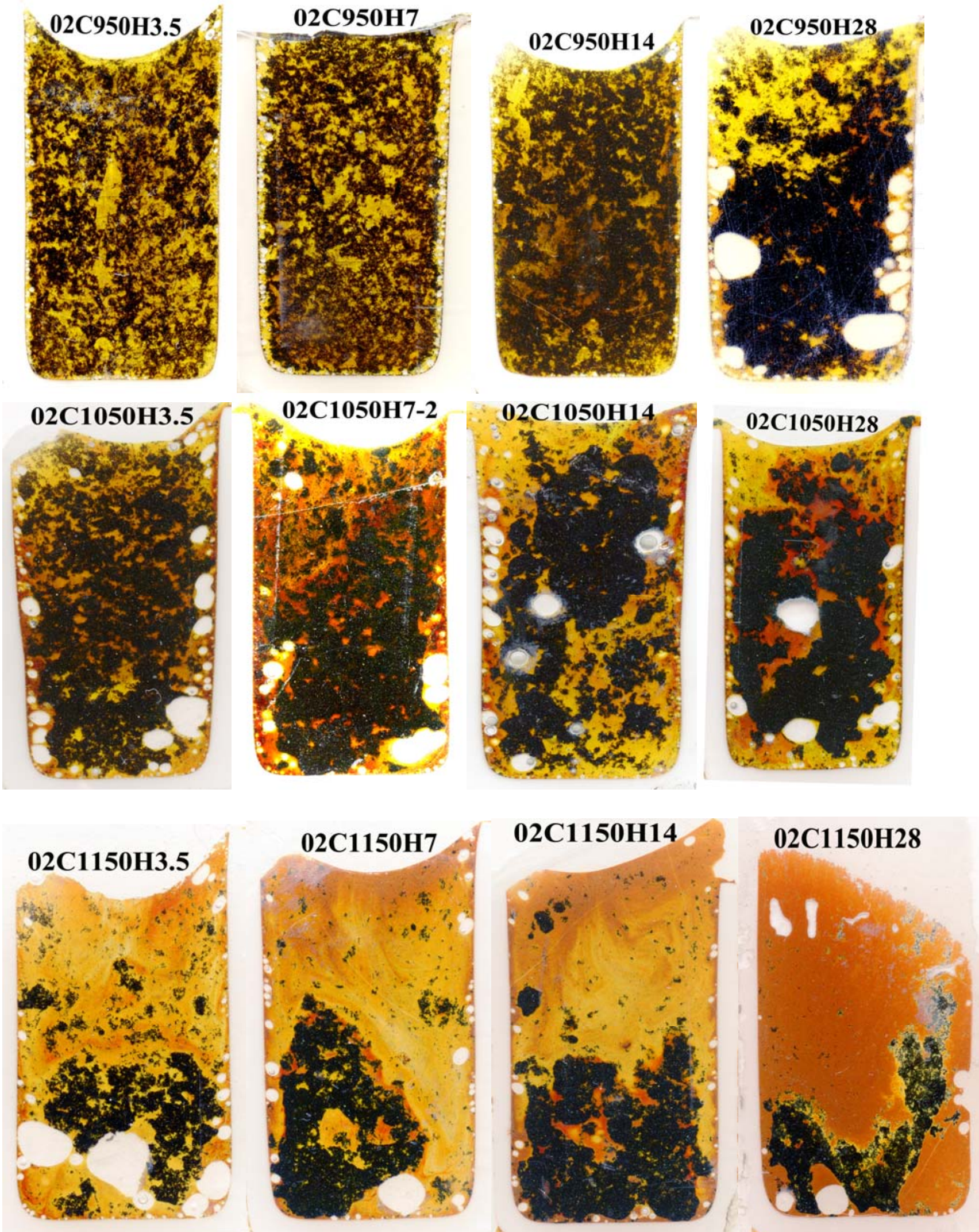

Figure 2.2. Scanned cross sections of HLW-E-ES-02 after crystal settling experiments at 950 (row 1), 1050 (row 2) and $1150^{\circ} \mathrm{C}$ (row 3) for 3.5, 7, 14 and 28 hours, respectively. Eskolaite appears as the opaque substance within the yellow/brown glass matrix. 
ORP-56295 Rev. 0

The Catholic University of America Vitreous State Laboratory
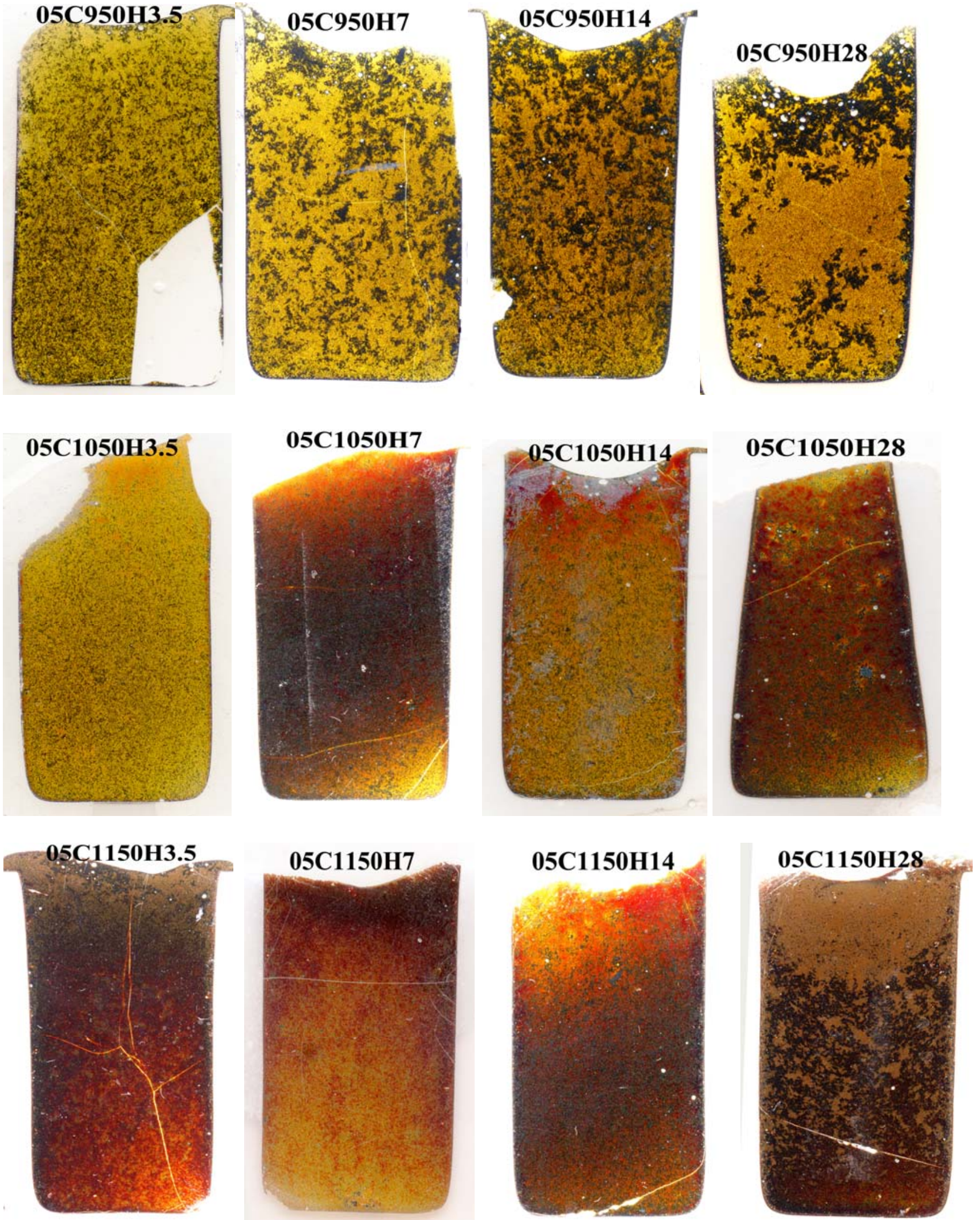

Figure 2.3. Scanned cross sections of HLW-E-SP-05 after crystal settling experiments at 950 (row 1), 1050 (row 2) and $1150^{\circ} \mathrm{C}$ (row 3) for 3.5, 7, 14 and 28 hours, respectively. Spinel appears as the opaque substance within the yellow/brown glass matrix. 

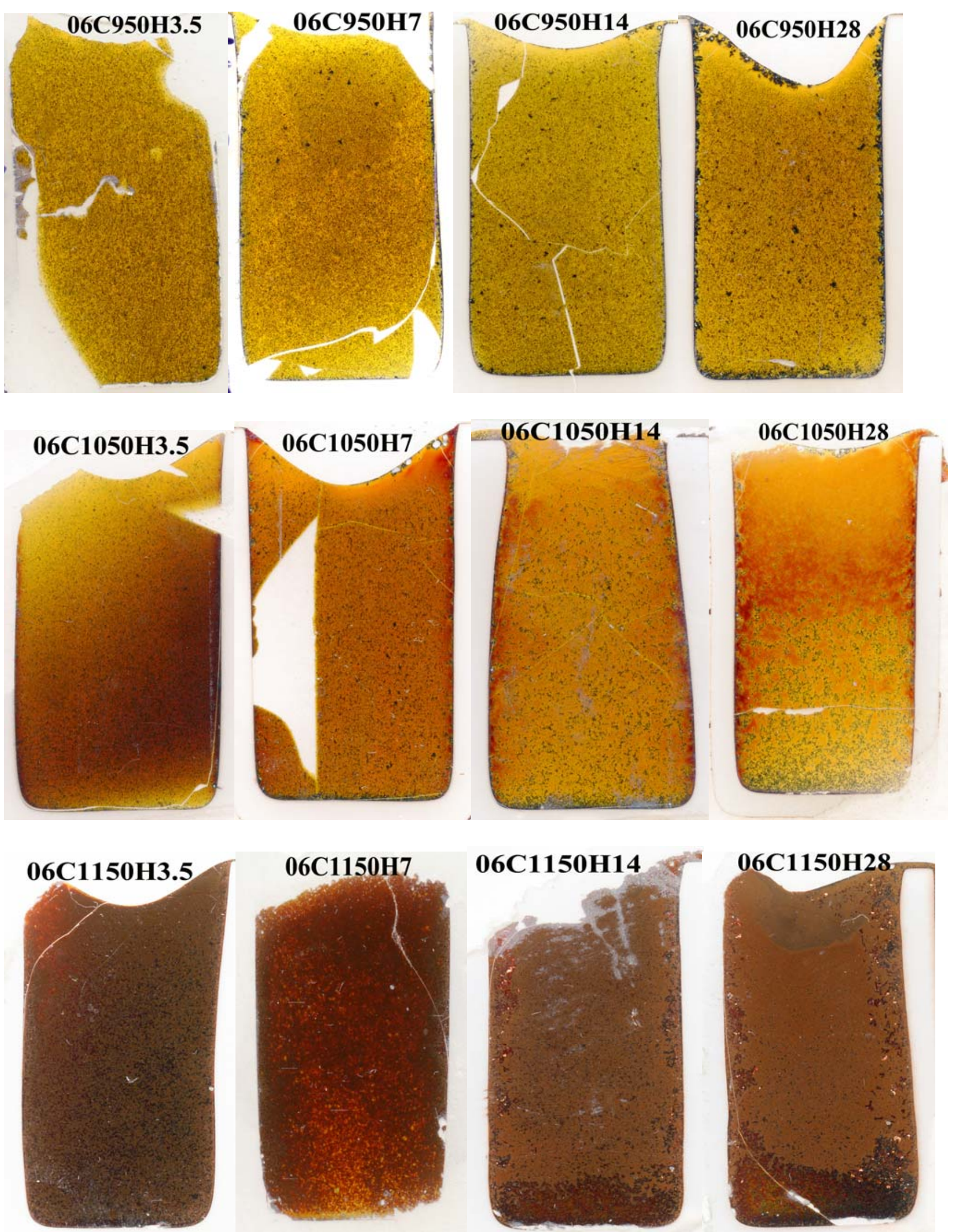

Figure 2.4. Scanned cross sections of HLW-E-SP-06 after crystal settling experiments at 950 (row 1), 1050 (row 2) and $1150^{\circ} \mathrm{C}$ (row 3) for 3.5, 7, 14 and 28 hours, respectively. Spinel appears as the opaque substance within the yellow/brown glass matrix. 
ORP-56295 Rev. 0

The Catholic University of America Vitreous State Laboratory
Crystal Settling, Redox, and Properties of ORP HLW \& LAW Glasses

Final Report, VSL-09R1510-1, Rev. 0
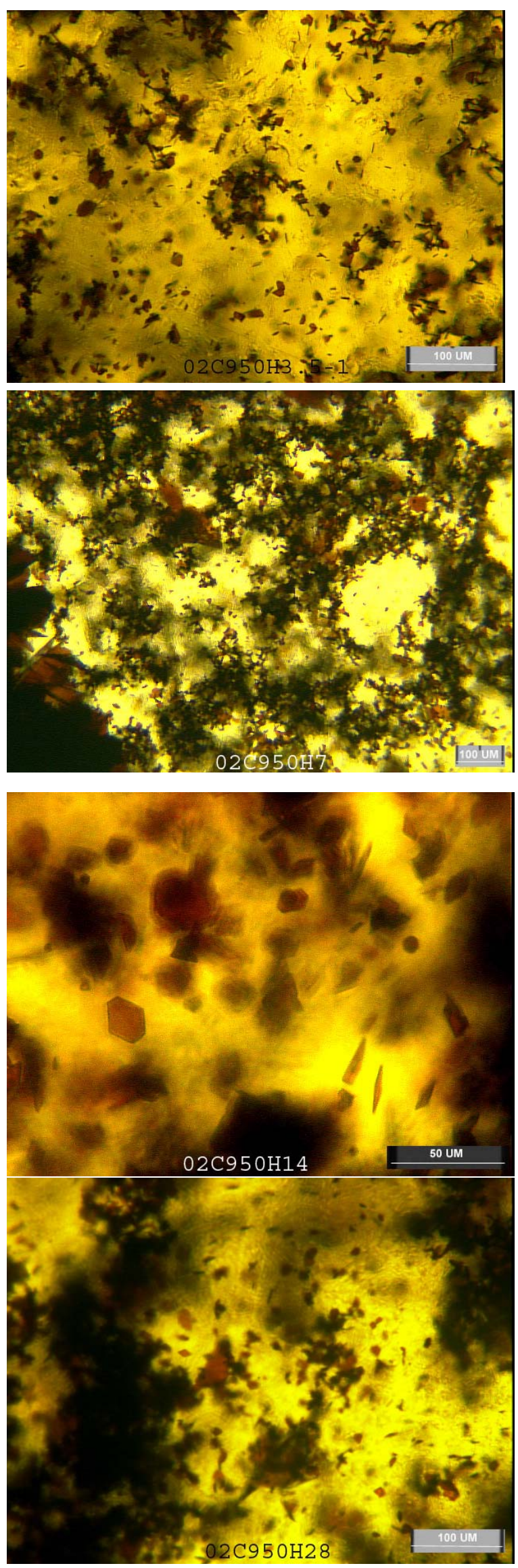

Figure 2.5a. Optical micro-images of eskolaite crystals in HLW-E-ES-02 after crystal settling experiments at $950^{\circ} \mathrm{C}$ for $3.5,7,14$ and 28 hours (top to bottom).

F-5 

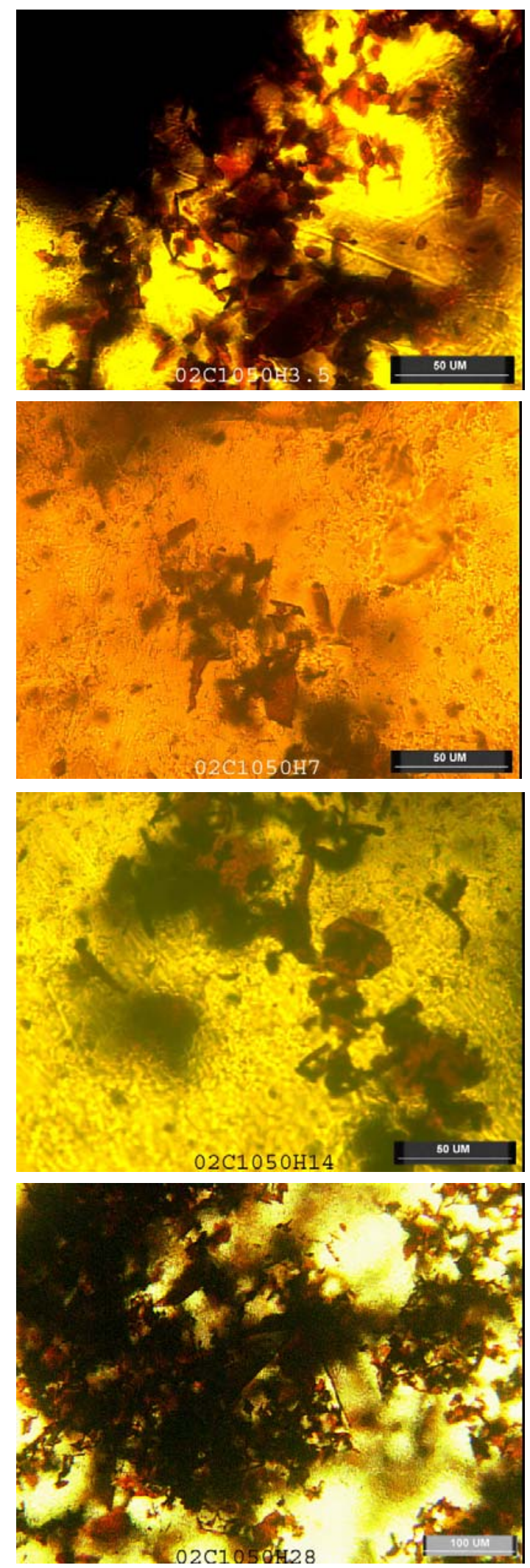

Figure 2.5b. Optical micro-images of eskolaite crystals in HLW-E-ES-02 after crystal settling experiments at $1050^{\circ} \mathrm{C}$ for $3.5,7,14$ and 28 hours (top to bottom). 


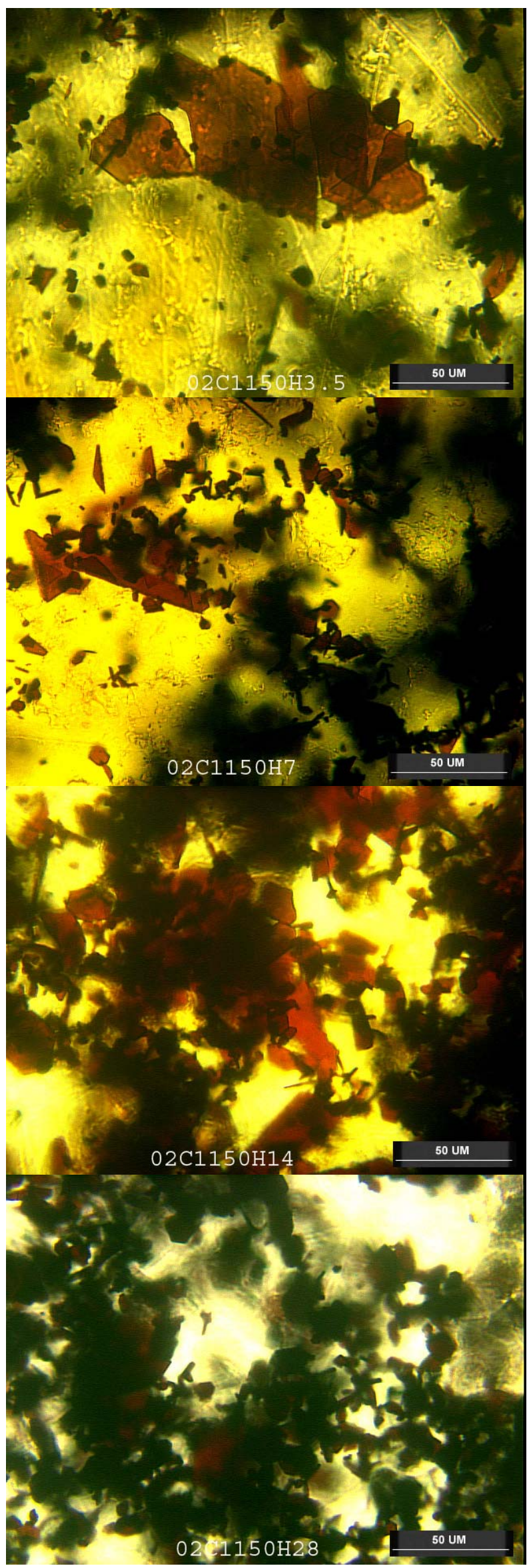

Figure 2.5c. Optical micro-images of eskolaite crystals in HLW-E-ES-02 after crystal settling experiments at $1150^{\circ} \mathrm{C}$ for $3.5,7,14$ and 28 hours (top to bottom). 
ORP-56295 Rev. 0

The Catholic University of America Vitreous State Laboratory
Crystal Settling, Redox, and Properties of ORP HLW \& LAW Glasses

Final Report, VSL-09R1510-1, Rev. 0

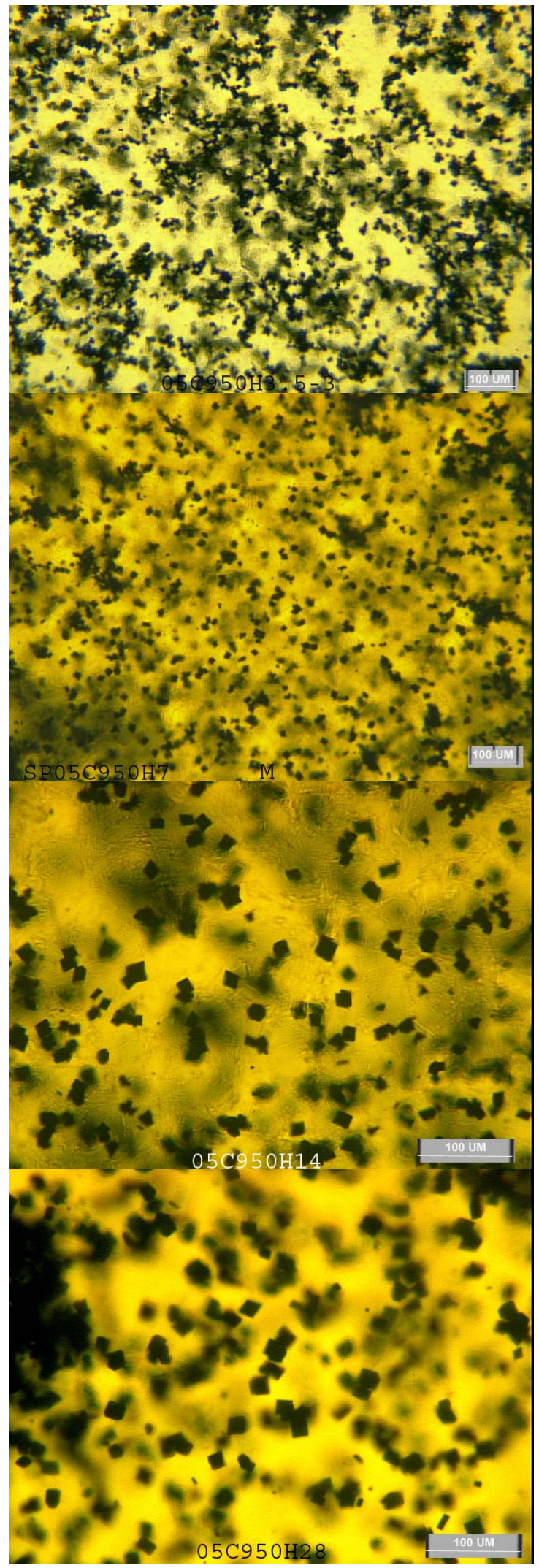

Figure 2.6a. Optical micro-images of crystal particles in HLW-E-SP-05 after crystal settling experiments at $950^{\circ} \mathrm{C}$ for $3.5,7,14$ and 28 hours (top to bottom). 
ORP-56295 Rev. 0

The Catholic University of America Vitreous State Laboratory
Crystal Settling, Redox, and Properties of ORP HLW \& LAW Glasses

Final Report, VSL-09R1510-1, Rev. 0

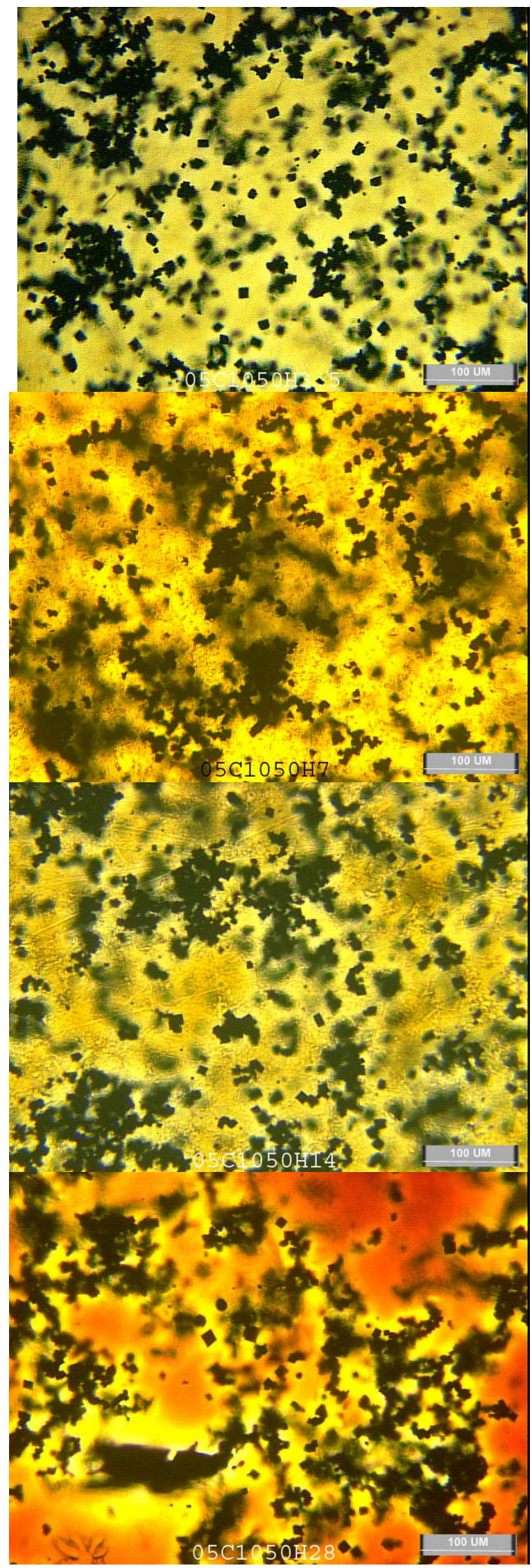

Figure 2.6b. Optical micro-images of crystal particles in HLW-E-SP-05 after crystal settling experiments at $1050^{\circ} \mathrm{C}$ for $3.5,7,14$ and 28 hours (top to bottom). 
ORP-56295 Rev. 0

The Catholic University of America Vitreous State Laboratory
Crystal Settling, Redox, and Properties of ORP HLW \& LAW Glasses

Final Report, VSL-09R1510-1, Rev. 0

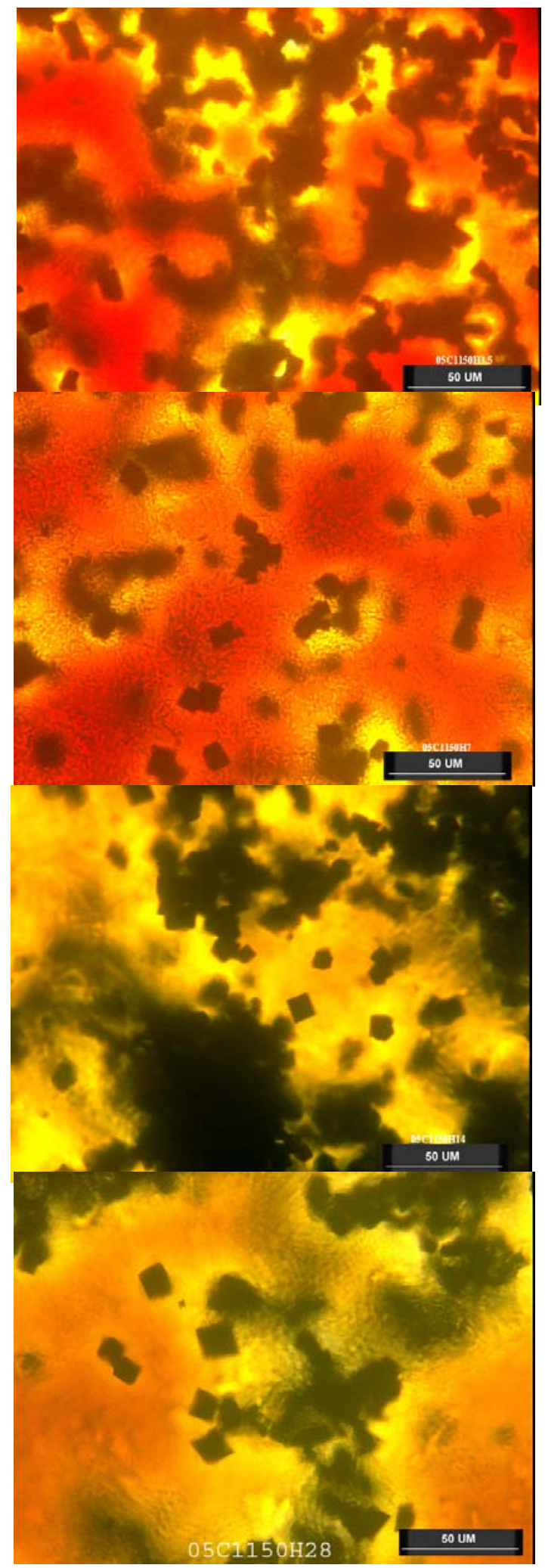

Figure 2.6c. Optical micro-images of crystal particles in HLW-E-SP-05 after crystal settling experiments at $1150^{\circ} \mathrm{C}$ for $3.5,7,14$ and 28 hours (top to bottom). 
ORP-56295 Rev. 0

The Catholic University of America Vitreous State Laboratory
Crystal Settling, Redox, and Properties of ORP HLW \& LAW Glasses

Final Report, VSL-09R1510-1, Rev. 0

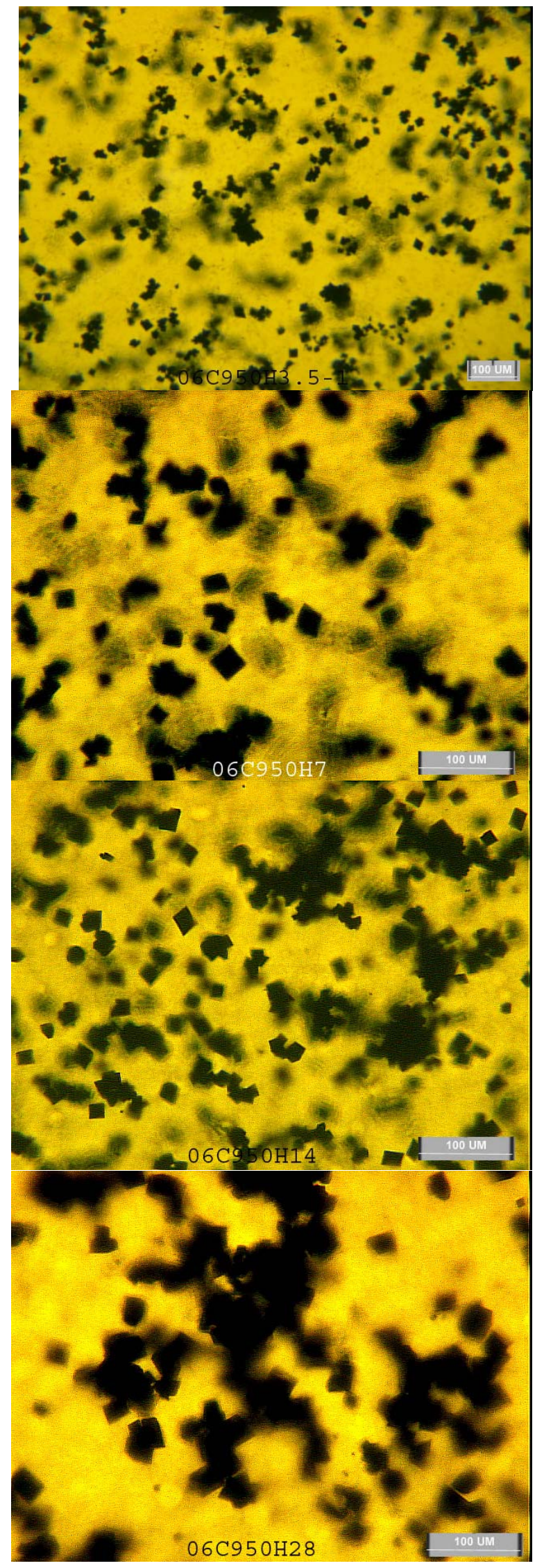

Figure 2.7a. Optical micro-images of crystal particles in HLW-E-SP-06 after crystal settling experiments at $950^{\circ} \mathrm{C}$ for $3.5,7,14$ and 28 hours (top to bottom). 


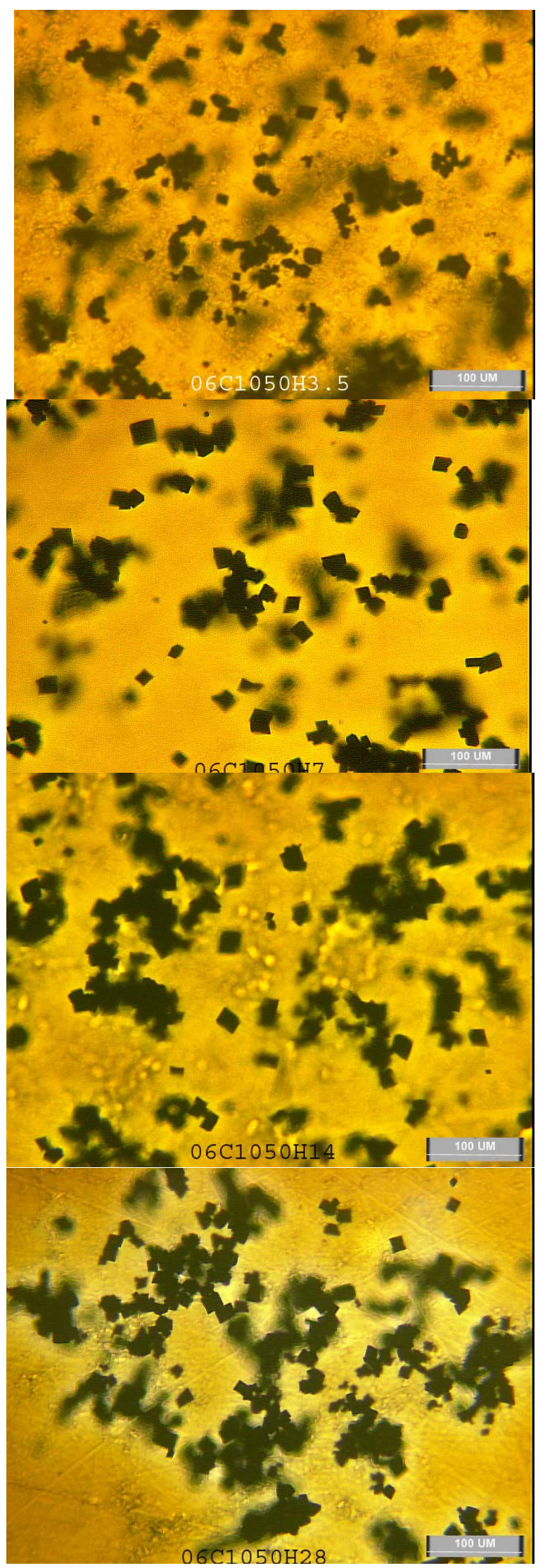

Figure 2.7b. Optical micro-images of crystal particles in HLW-E-SP-06 after crystal settling experiments at $1050^{\circ} \mathrm{C}$ for $3.5,7,14$ and 28 hours (top to bottom). 
ORP-56295 Rev. 0

The Catholic University of America Vitreous State Laboratory
Crystal Settling, Redox, and Properties of ORP HLW \& LAW Glasses

Final Report, VSL-09R1510-1, Rev. 0

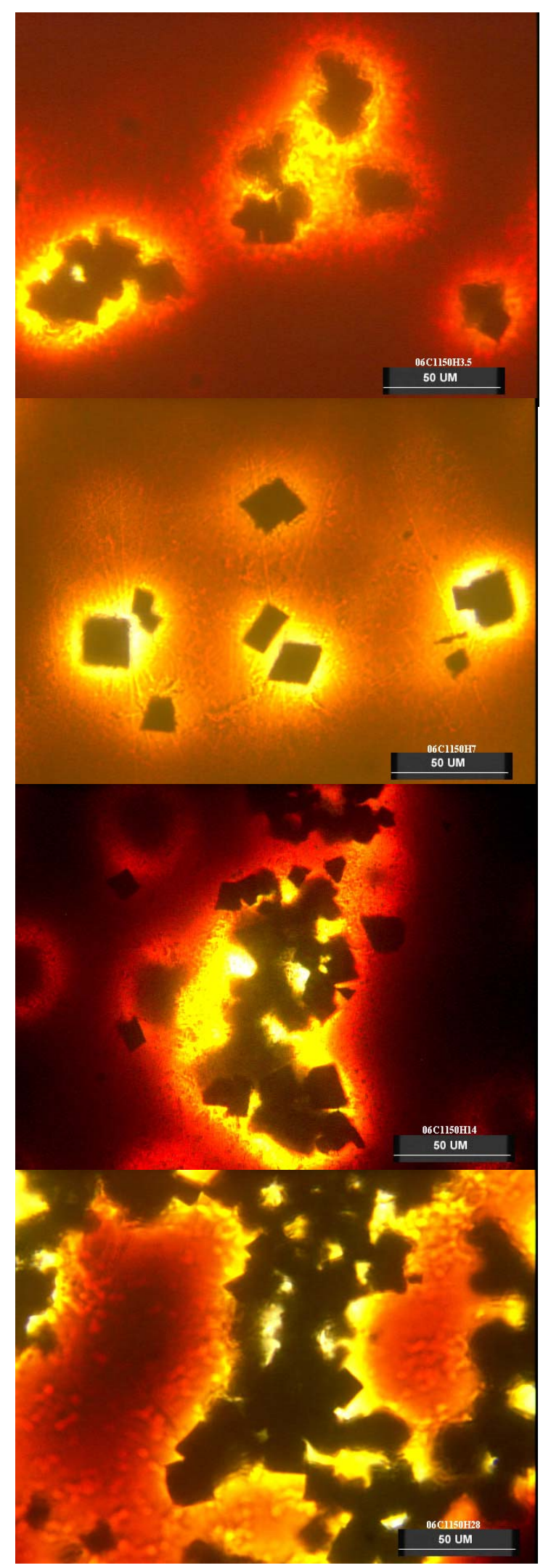

Figure 2.7c. Optical micro-images of crystal particles in HLW-E-SP-06 after crystal settling experiments at $1150^{\circ} \mathrm{C}$ for $3.5,7,14$ and 28 hours (top to bottom). 


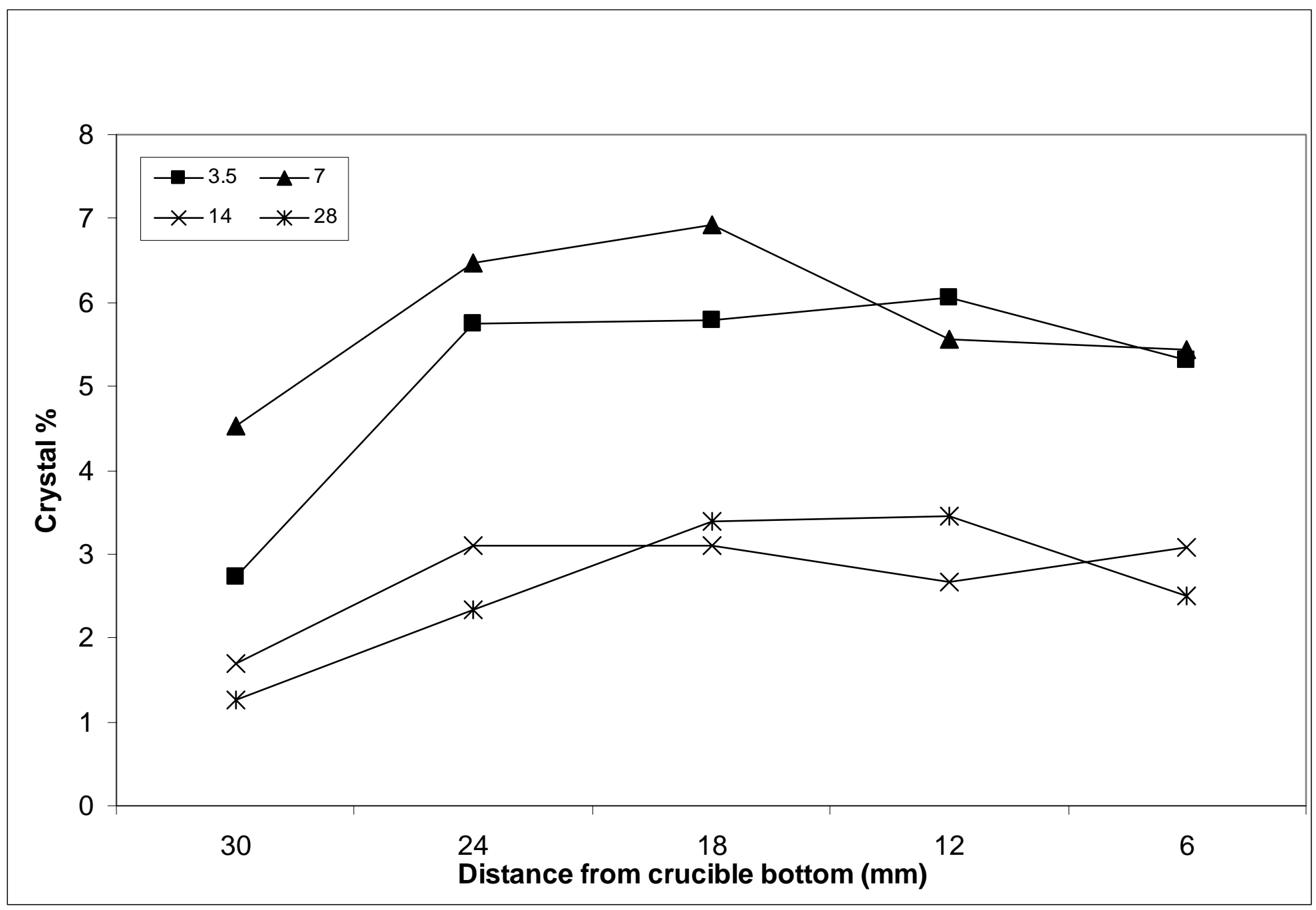

Figure 2.8a. Crystal content distribution in the test crucible for HLW-E-ES-02 settling experiments at $950^{\circ} \mathrm{C}$ for 3.5, 7, 14 and 28 hours.

(Standard deviation of the vol\% crystals measurement is 0.5 vol\%) 


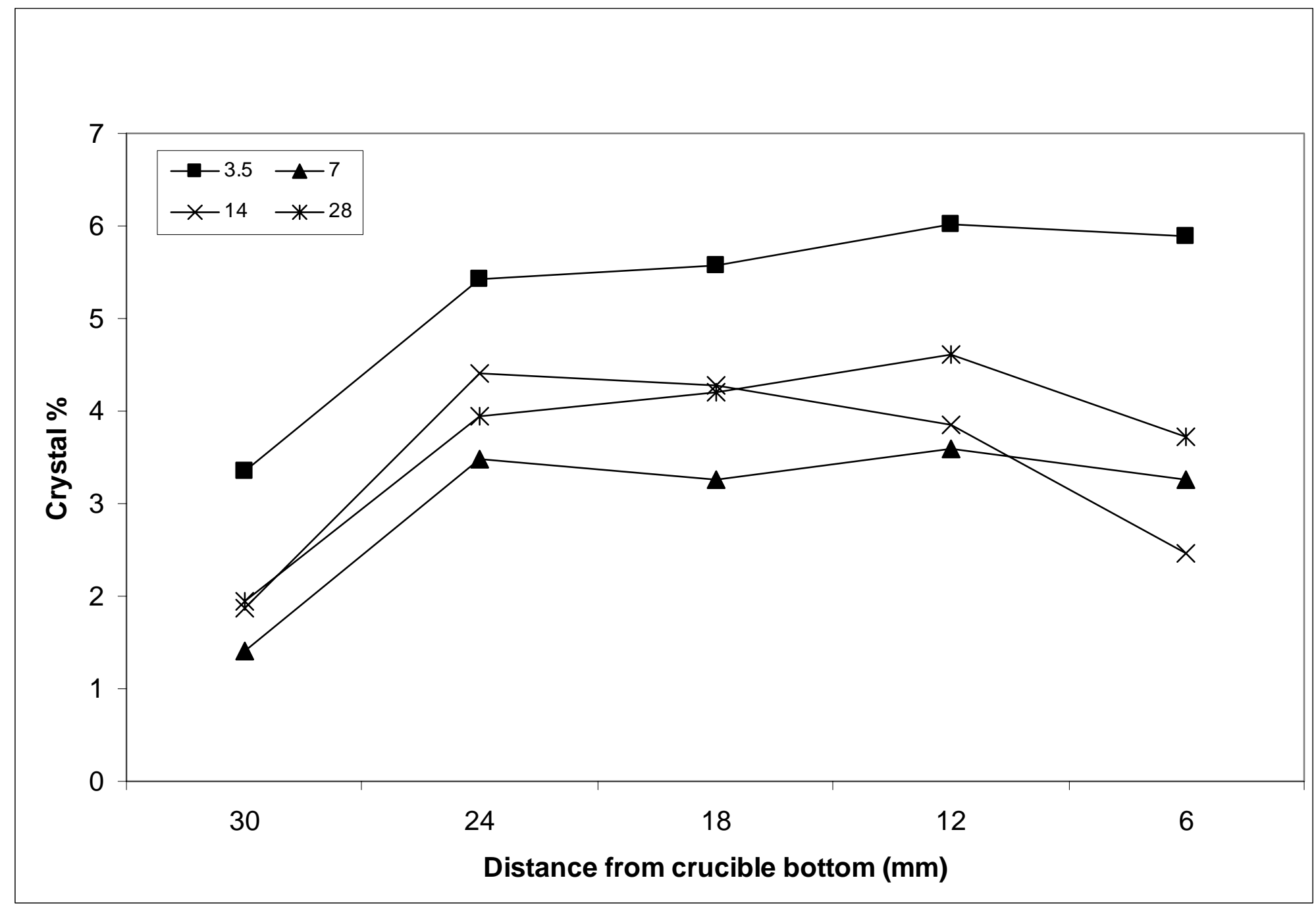

Figure 2.8b. Crystal content distribution in the test crucible for HLW-E-ES-02 settling experiments at $1050^{\circ} \mathrm{C}$ for $3.5,7,14$ and 28 hours.

(Standard deviation of the vol\% crystals measurement is 0.5 vol\%) 


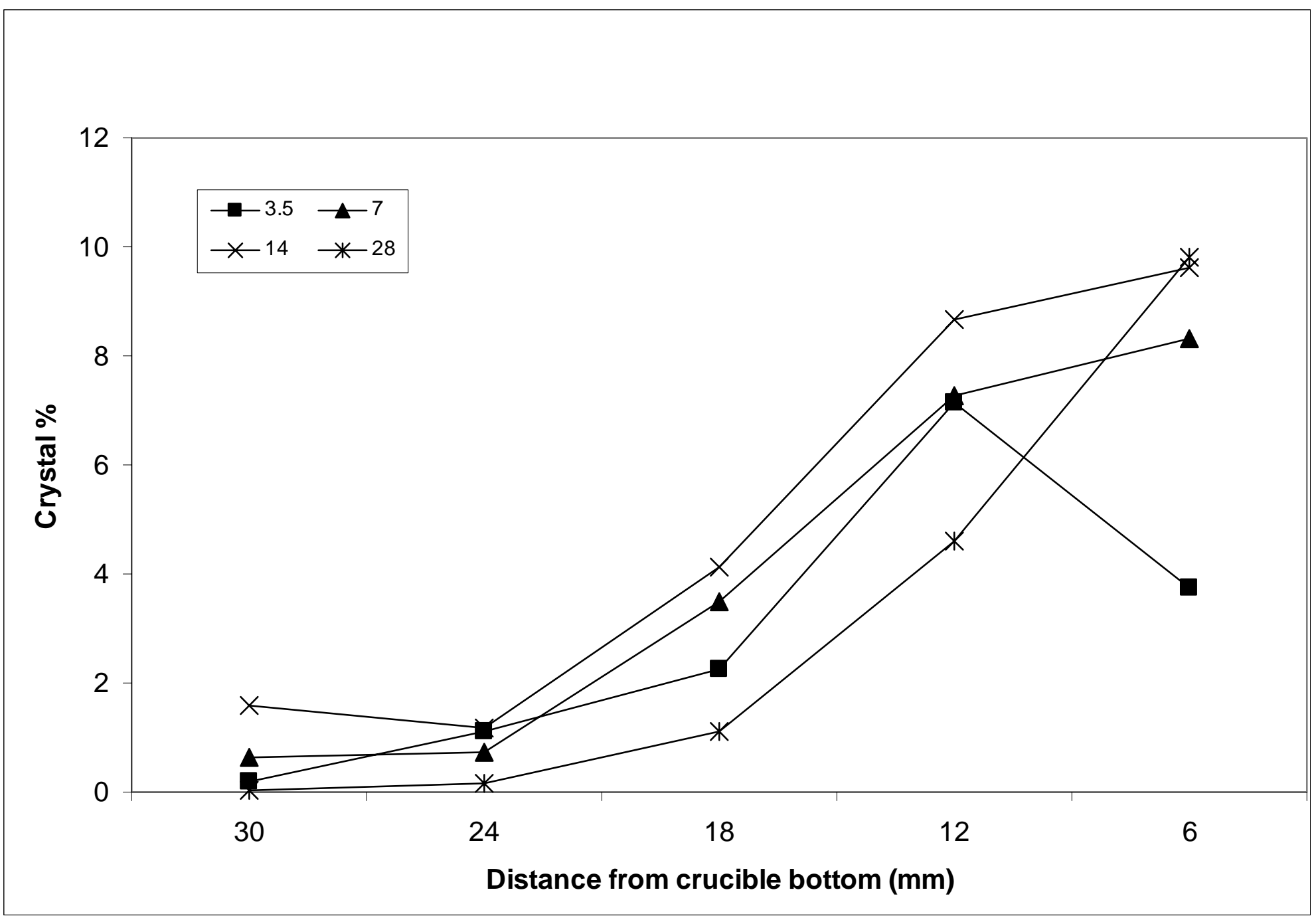

Figure 2.8c. Crystal content distribution in the test crucible for HLW-E-ES-02 settling experiments at $1150^{\circ} \mathrm{C}$ for $3.5,7,14$ and 28 hours.

(Standard deviation of the vol\% crystals measurement is $0.5 \mathrm{vol} \%$ ) 


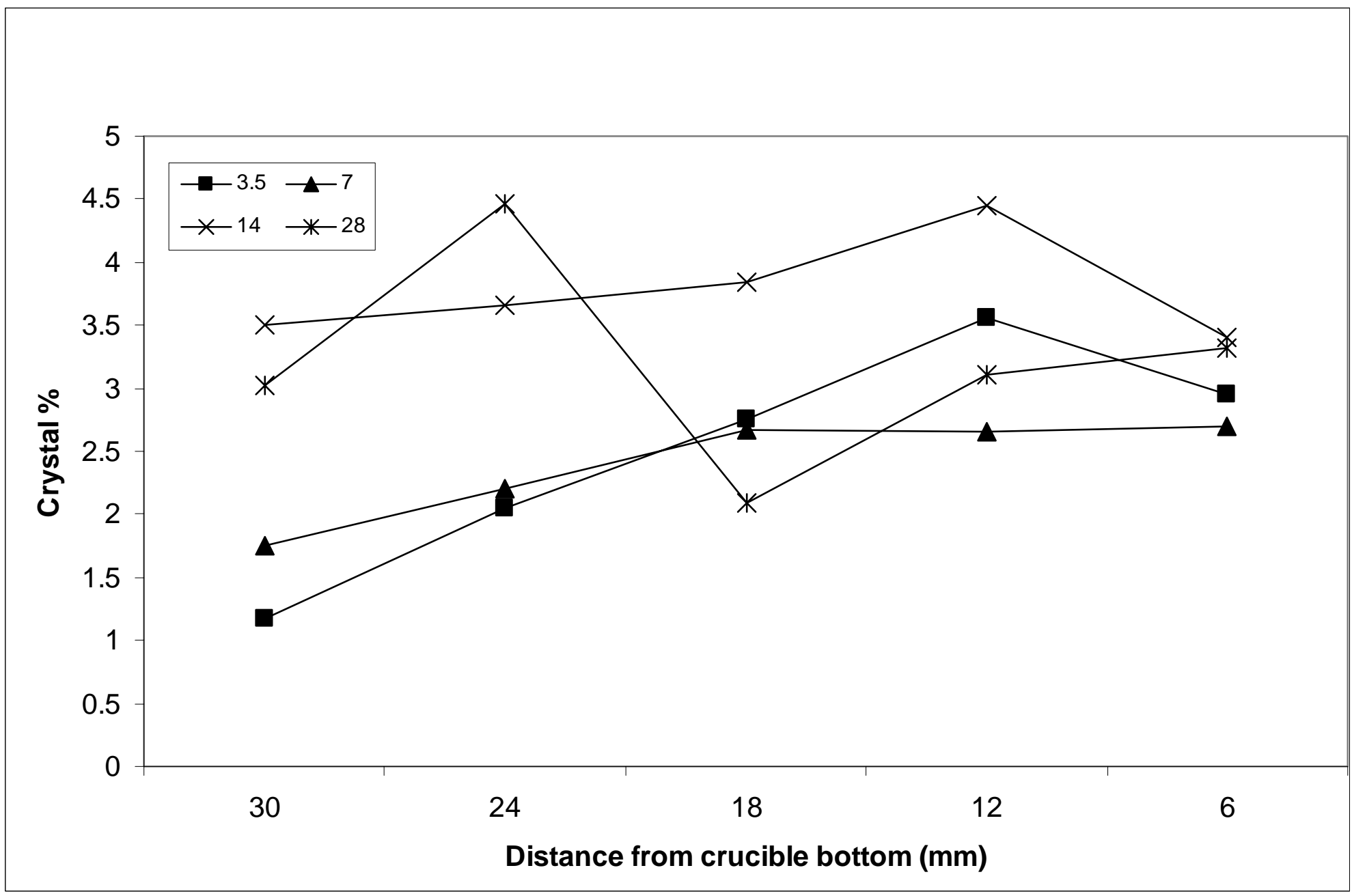

Figure 2.9a. Crystal content distribution in the test crucible for $\mathrm{HLW}$-E-SP-05 settling experiments $950^{\circ} \mathrm{C}$ for 3.5 , 7, 14 and 28 hours.

(Standard deviation of the vol\% crystals measurement is 0.5 vol\%) 


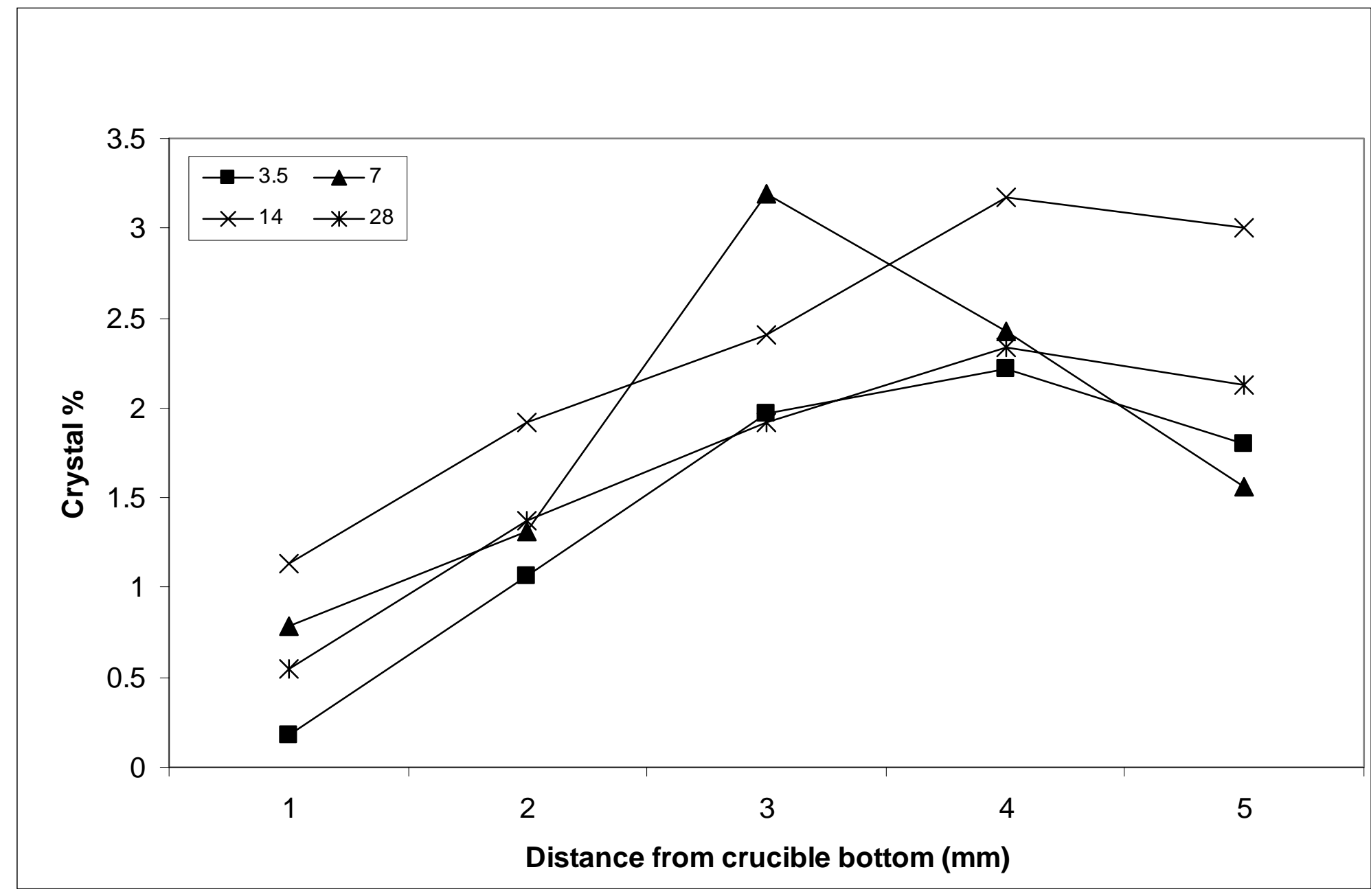

Figure 2.9b. Crystal content distribution in the test crucible for HLW-E-SP-05 settling experiments at $1050^{\circ} \mathrm{C}$ for $3.5,7,14$ and 28 hours.

(Standard deviation of the vol\% crystals measurement is $0.5 \mathrm{vol} \%$ ) 


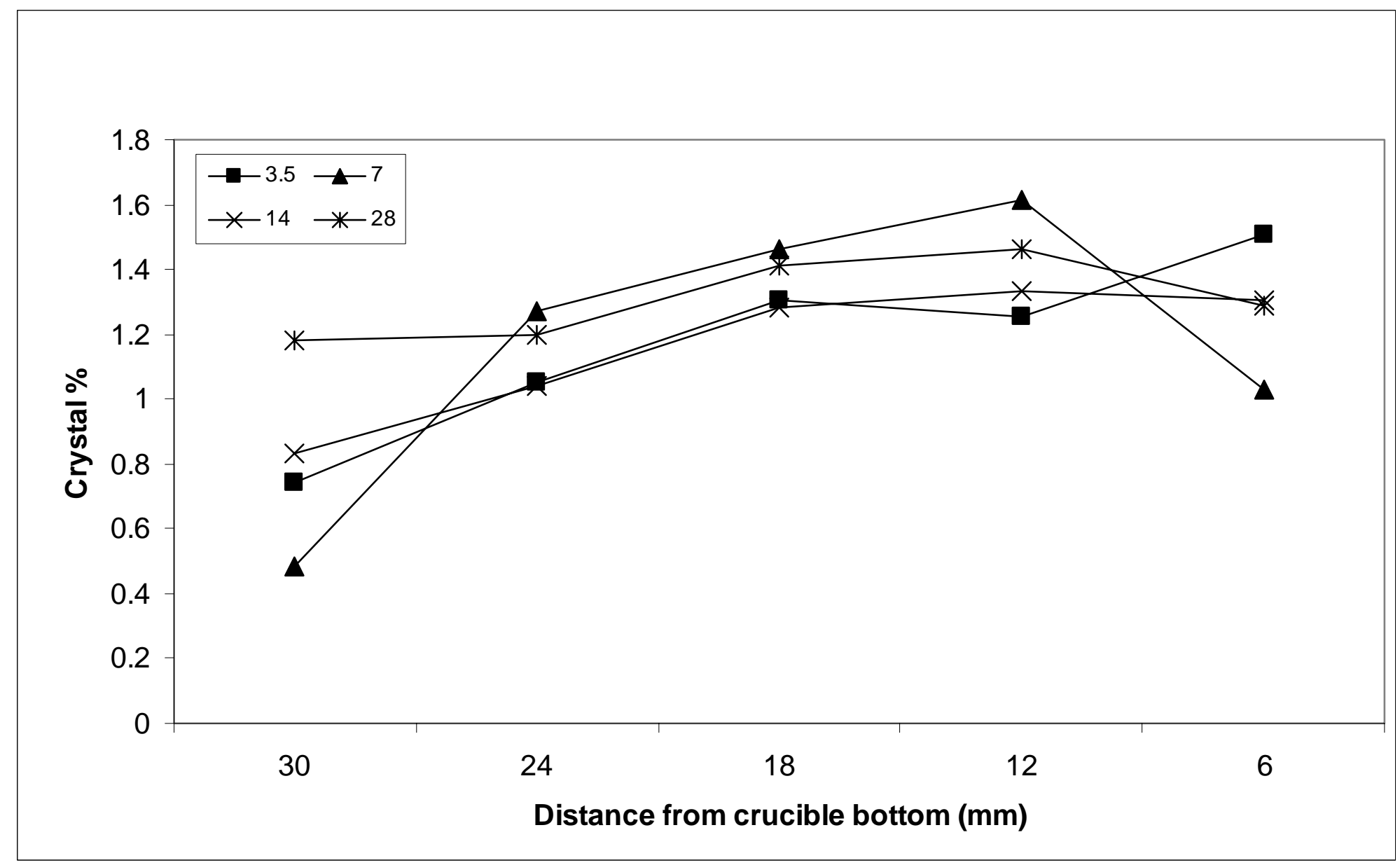

Figure 2.10a. Crystal content distribution in the test crucible for HLW-E-SP-06 settling experiments at $950^{\circ} \mathrm{C}$ for 3.5, 7, 14 and 28 hours.

(Standard deviation of the vol\% crystals measurement is $0.5 \mathrm{vol} \%$ ) 


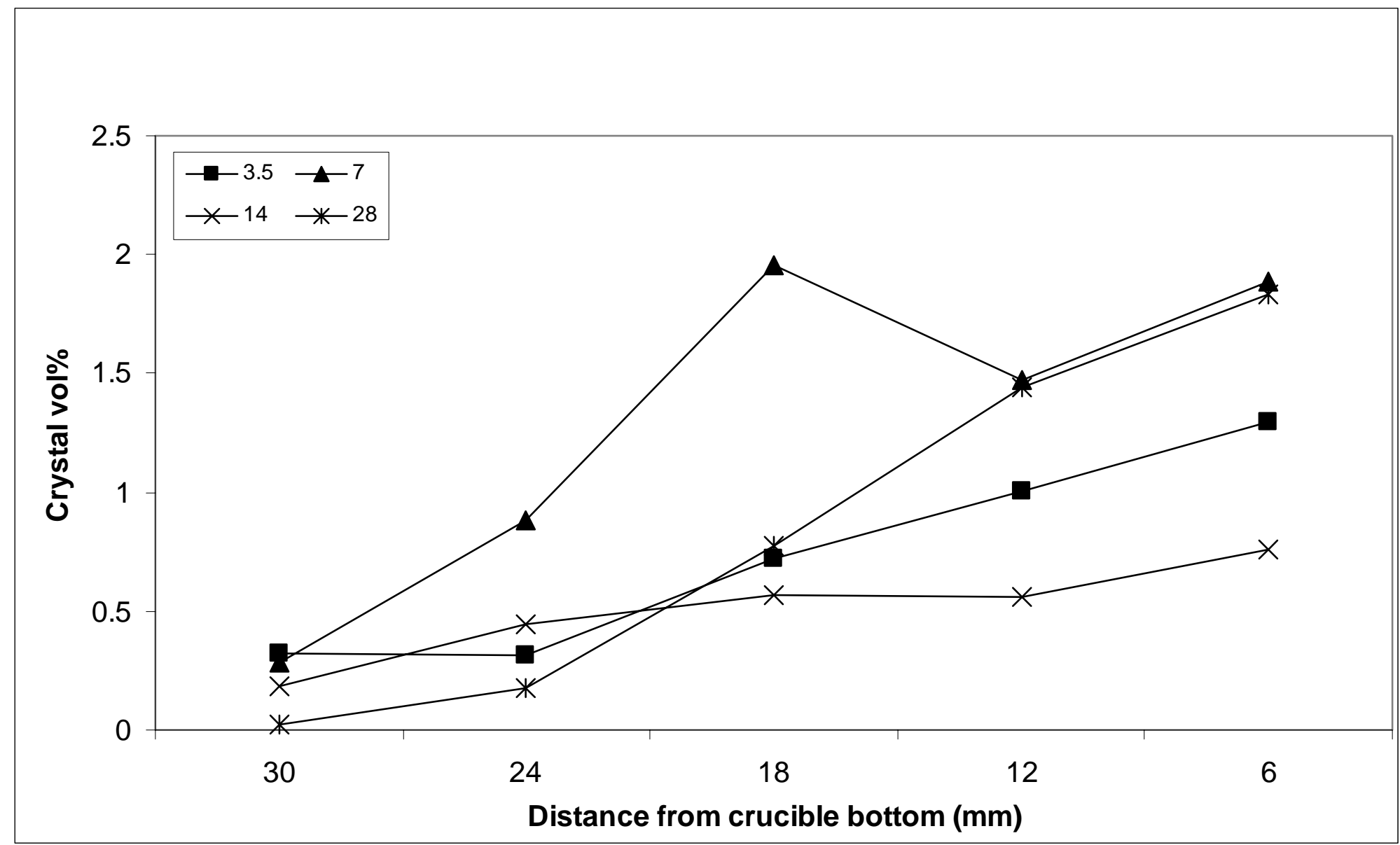

Figure 2.10b. Crystal content distribution in the test crucible for HLW-E-SP-06 settling experiments at $1050^{\circ} \mathrm{C}$ for $3.5,7,14$ and 28 hours.

(Standard deviation of the vol\% crystals measurement is $0.5 \mathrm{vol} \%$ ) 


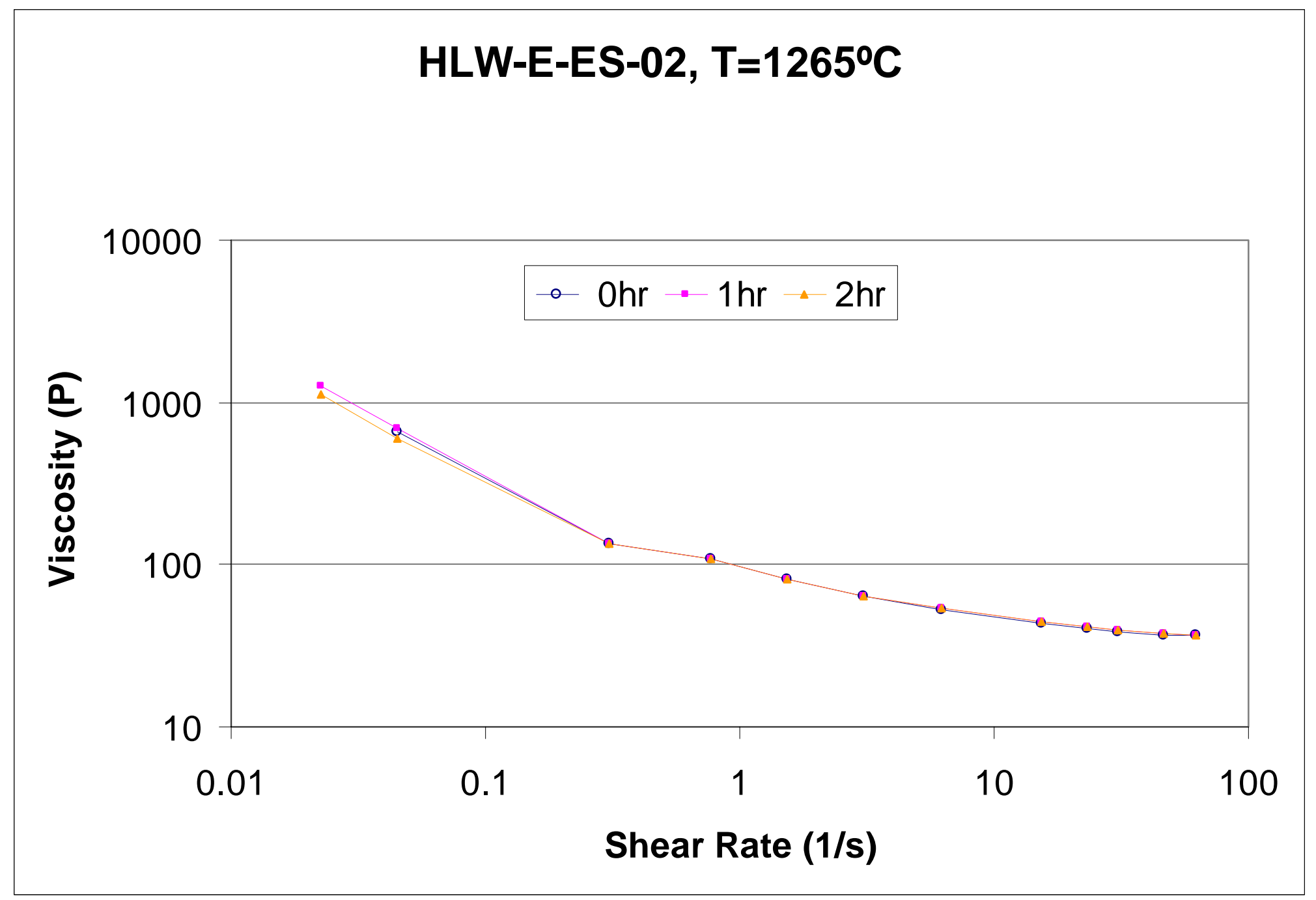

Figure 2.11a. Viscosity vs. shear rate for HLW-E-ES-02 at $1265^{\circ} \mathrm{C}$.

(Uncertainty in viscosity measurement with this equipment is $\pm 10 \%$ ) 


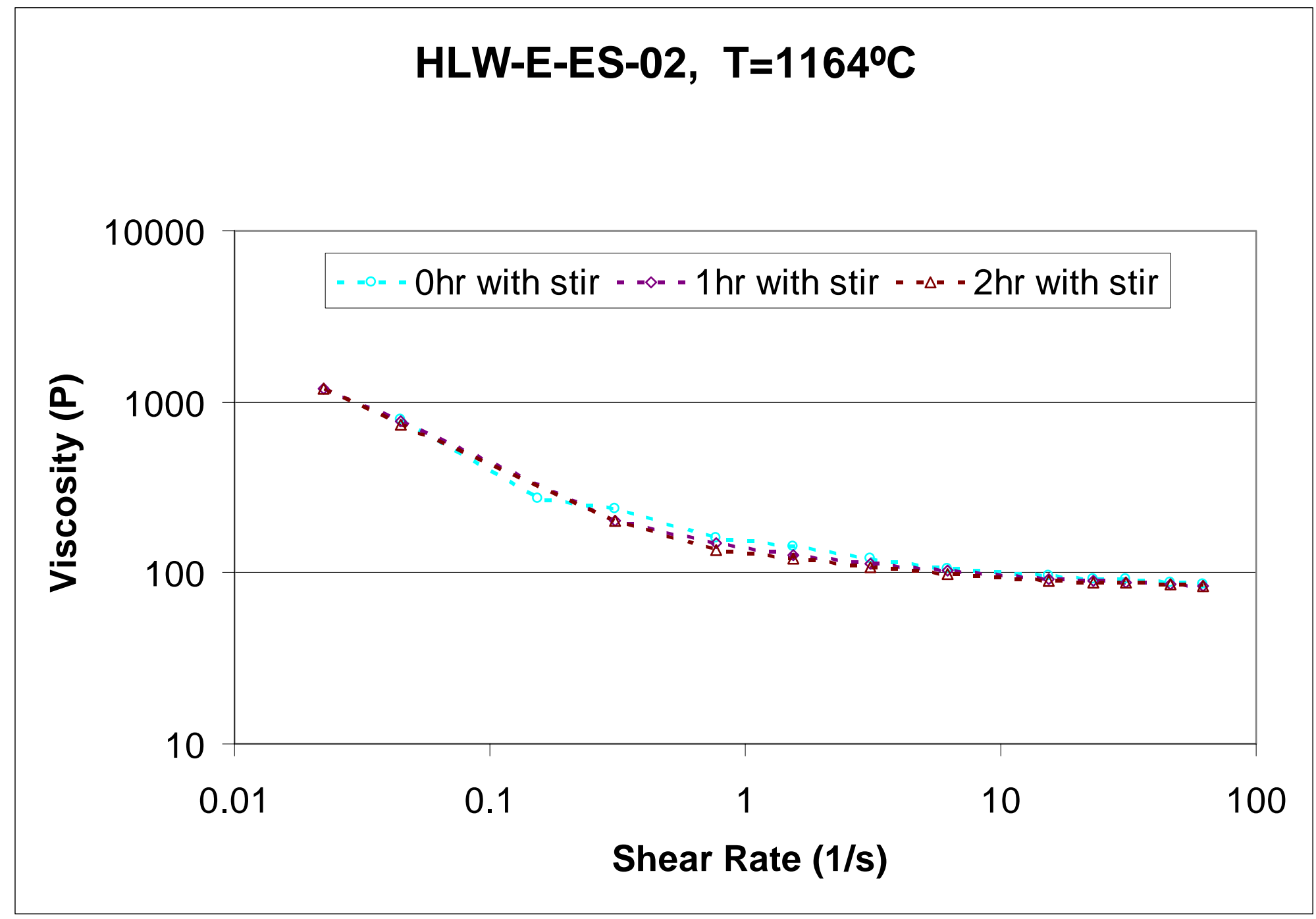

Figure 2.11b. Viscosity vs. shear rate for HLW-E-ES-02 at $1164^{\circ} \mathrm{C}$.

(Uncertainty in viscosity measurement with this equipment is $\pm 10 \%$ ) 


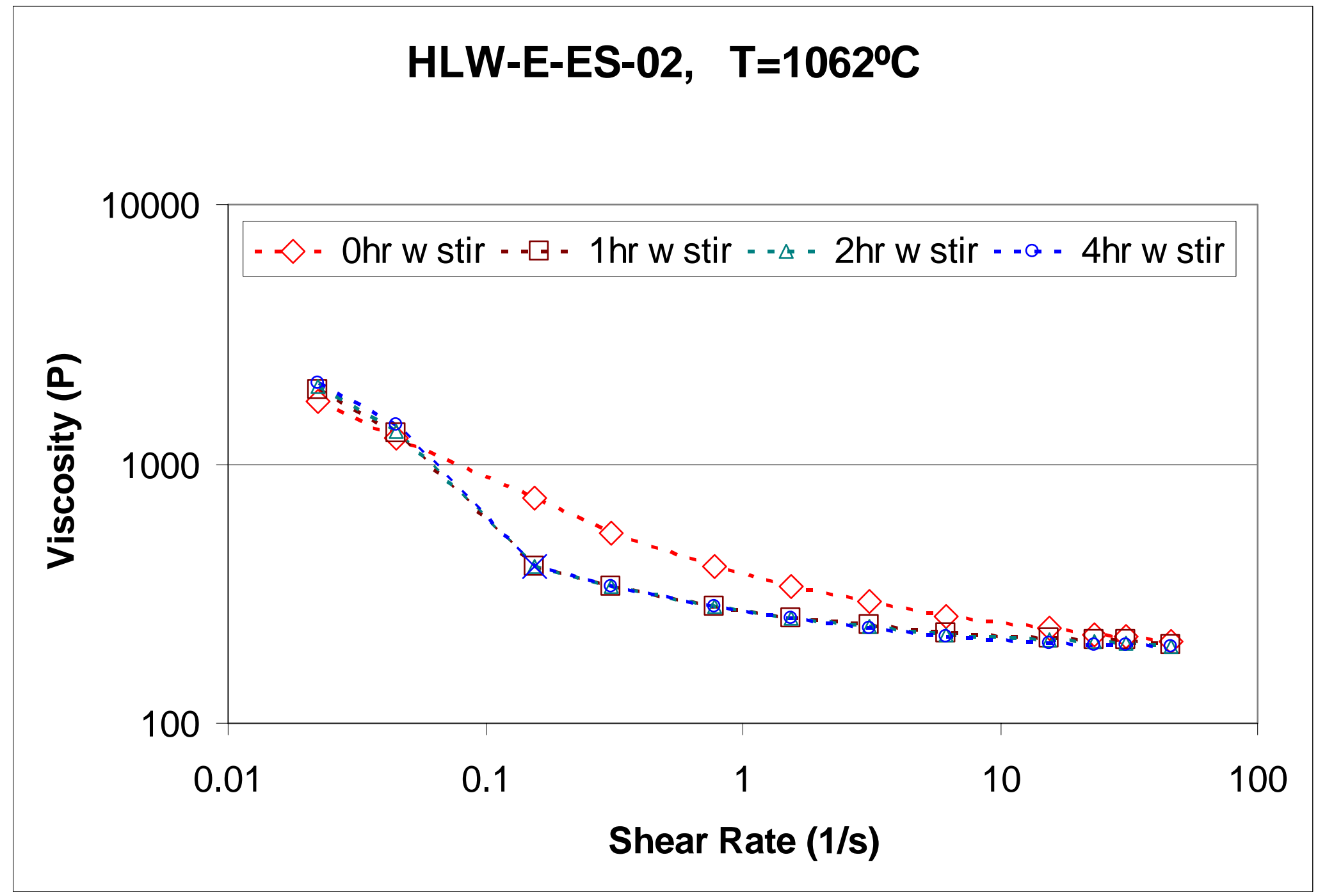

Figure 2.11c. Viscosity vs. shear rate for HLW-E-ES-02 at $1062^{\circ} \mathrm{C}$.

(Uncertainty in viscosity measurement with this equipment is $\pm 10 \%$ ) 


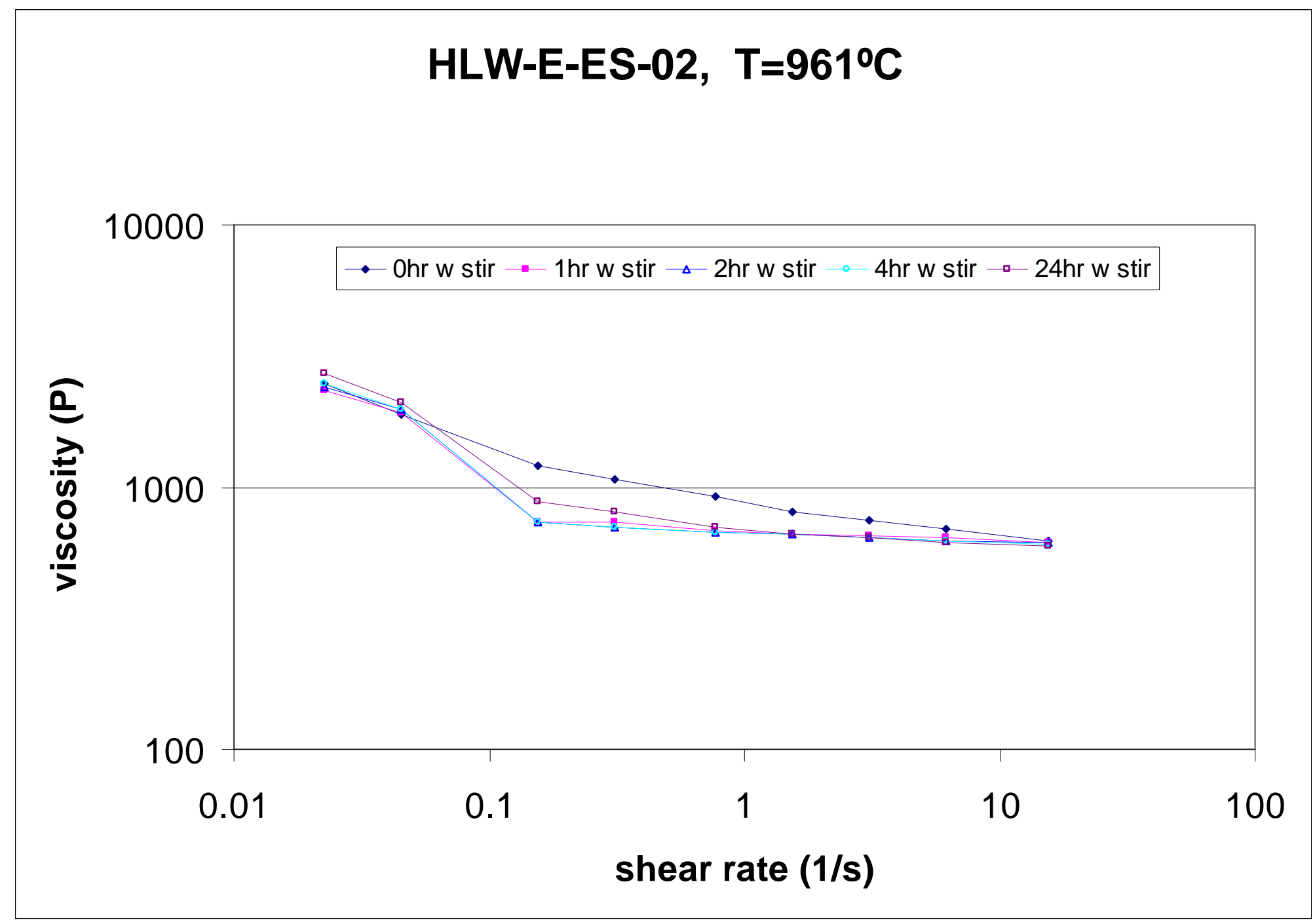

Figure 2.11d. Viscosity vs. shear rate for HLW-E-ES-02 at $961^{\circ} \mathrm{C}$. (Uncertainty in viscosity measurement with this equipment is $\pm 10 \%$ ) 


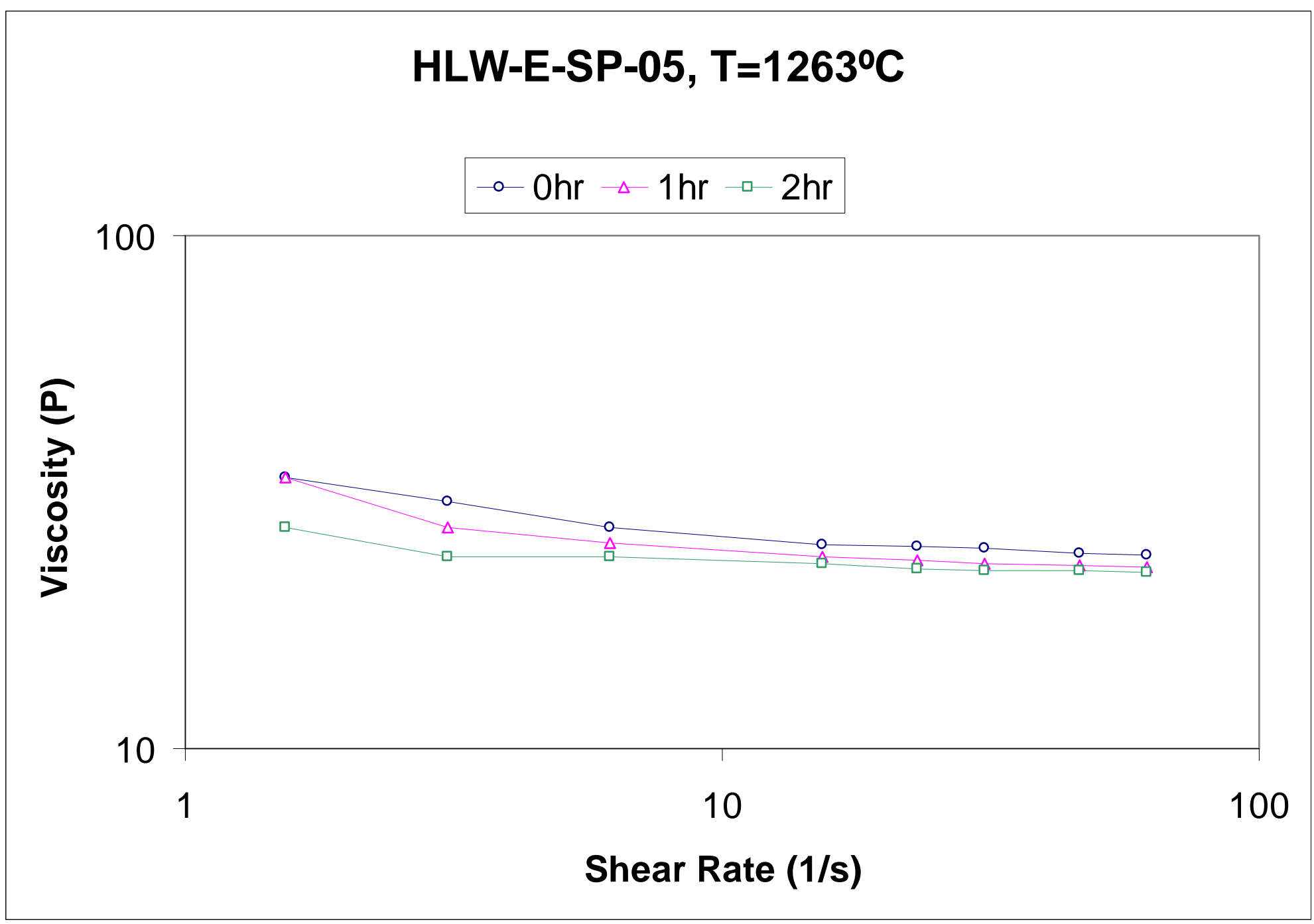

Figure 2.12a. Viscosity vs. shear rate for $\mathrm{HLW}-\mathrm{E}-\mathrm{SP}-05$ at $1263^{\circ} \mathrm{C}$. (Uncertainty in viscosity measurement with this equipment is $\pm 10 \%$ ) 


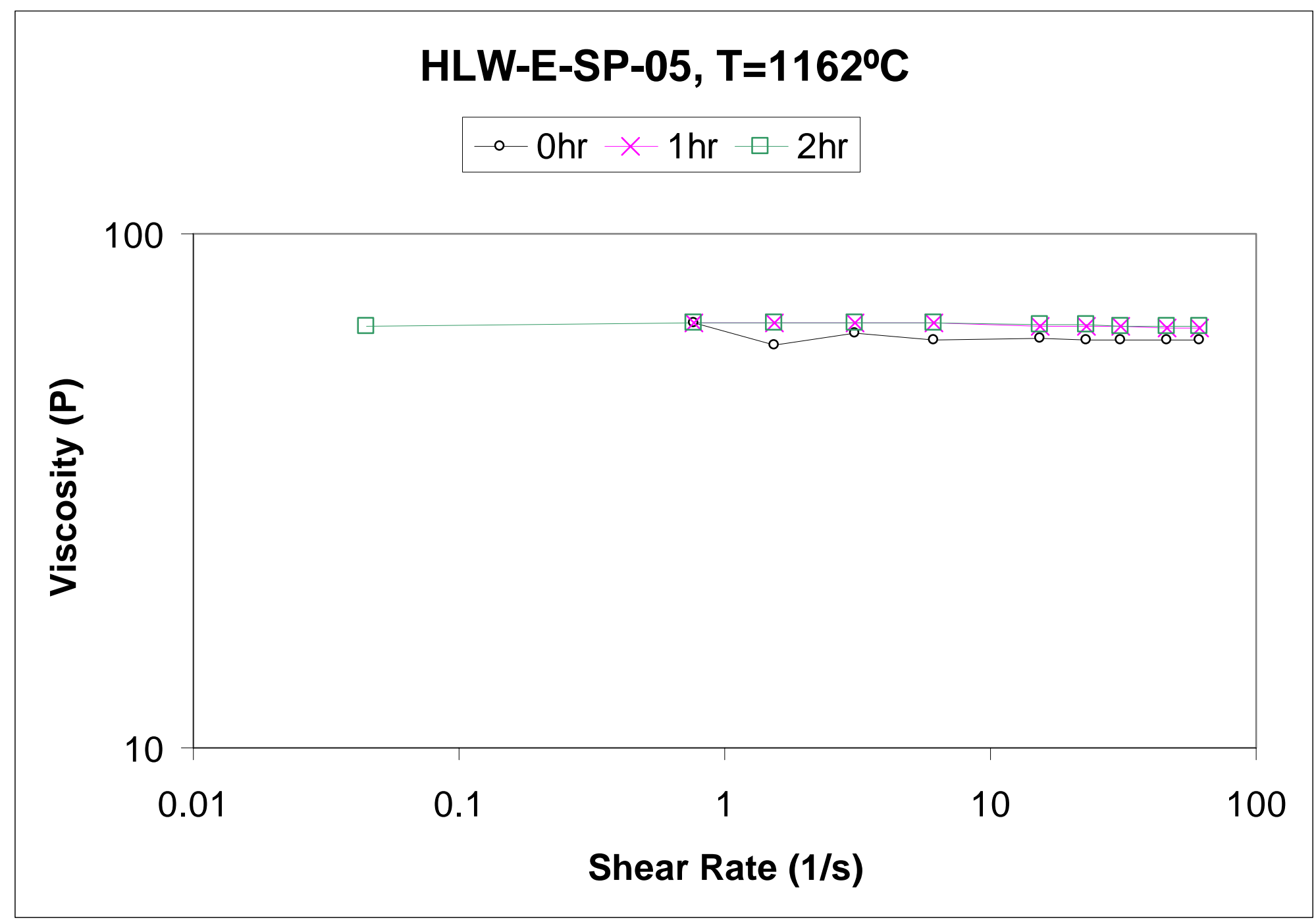

Figure 2.12b. Viscosity vs. shear rate for HLW-E-SP-05 at $1162^{\circ} \mathrm{C}$. (Uncertainty in viscosity measurement with this equipment is $\pm \mathbf{1 0} \%$ ) 


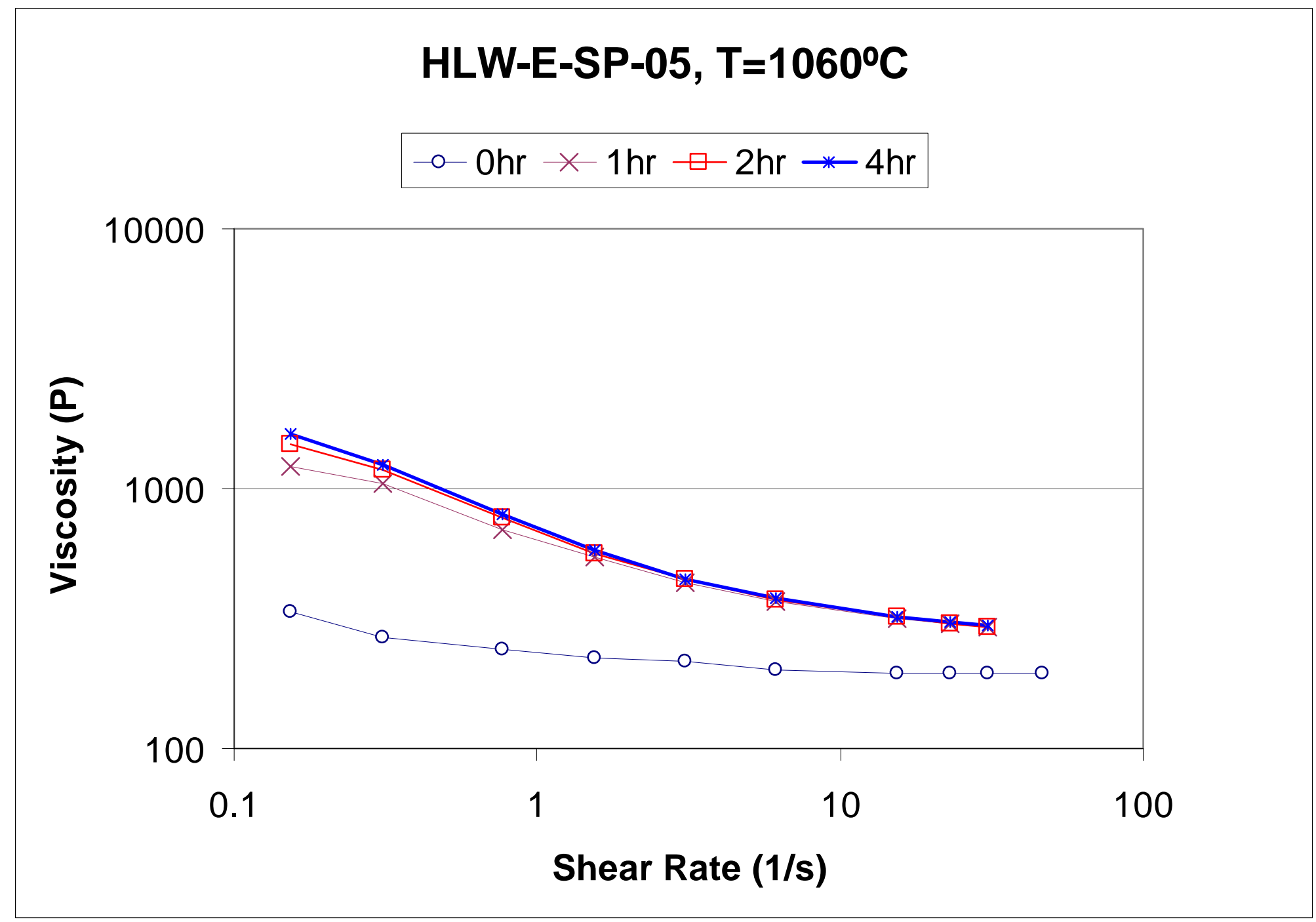

Figure 2.12c. Viscosity vs. shear rate for HLW-E-SP-05 at $1060^{\circ} \mathrm{C}$.

(Uncertainty in viscosity measurement with this equipment is $\pm 10 \%$ ) 


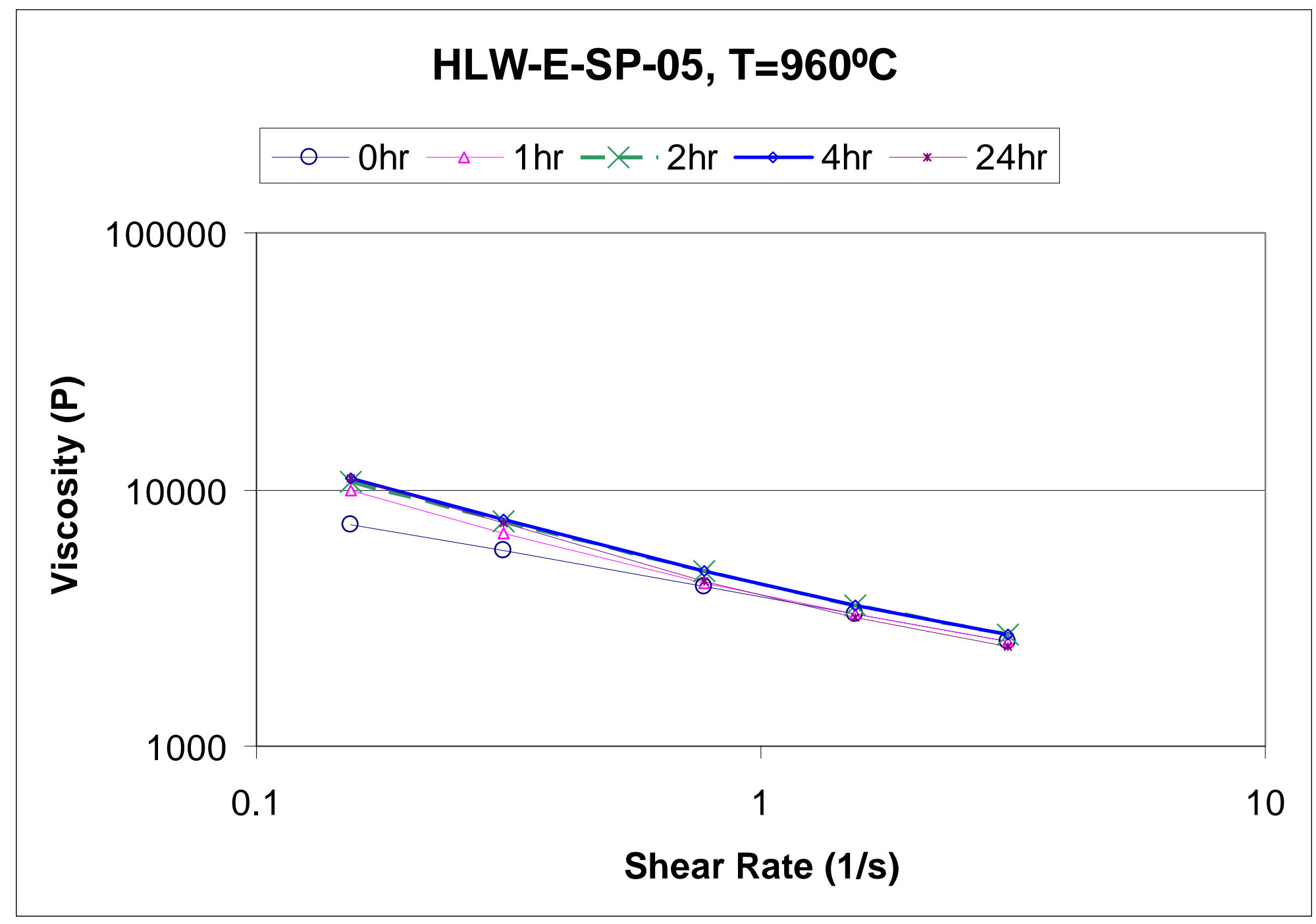

Figure 2.12d. Viscosity vs. shear rate for $\mathrm{HLW}$-E-SP-05 at $960^{\circ} \mathrm{C}$.

(Uncertainty in viscosity measurement with this equipment is $\pm 10 \%$ ) 


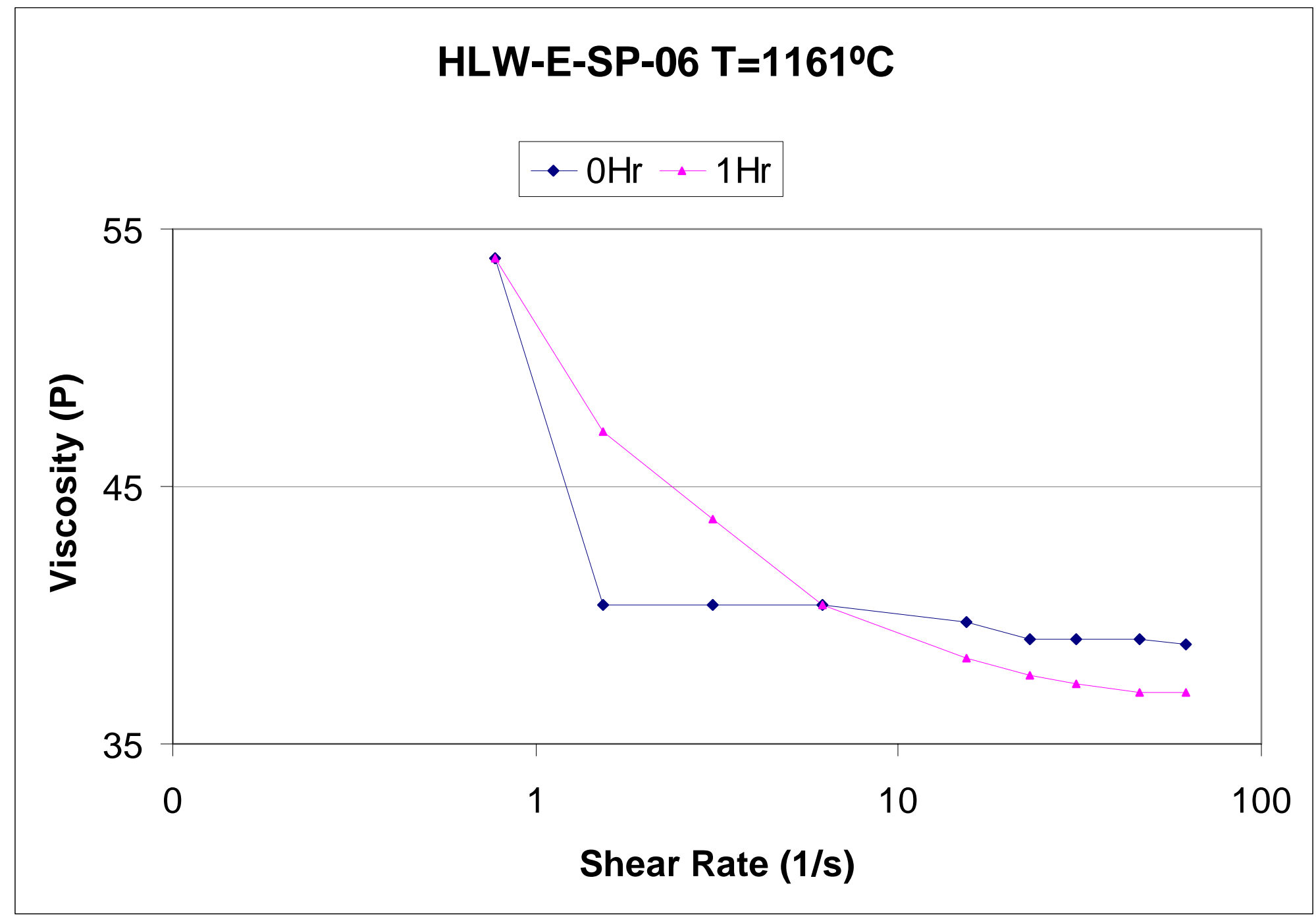

Figure 2.13a. Viscosity vs. shear rate for $\mathrm{HLW}-\mathrm{E}-\mathrm{SP}-06$ at $1161^{\circ} \mathrm{C}$. (Uncertainty in viscosity measurement with this equipment is $\pm \mathbf{1 0} \%$ ) 


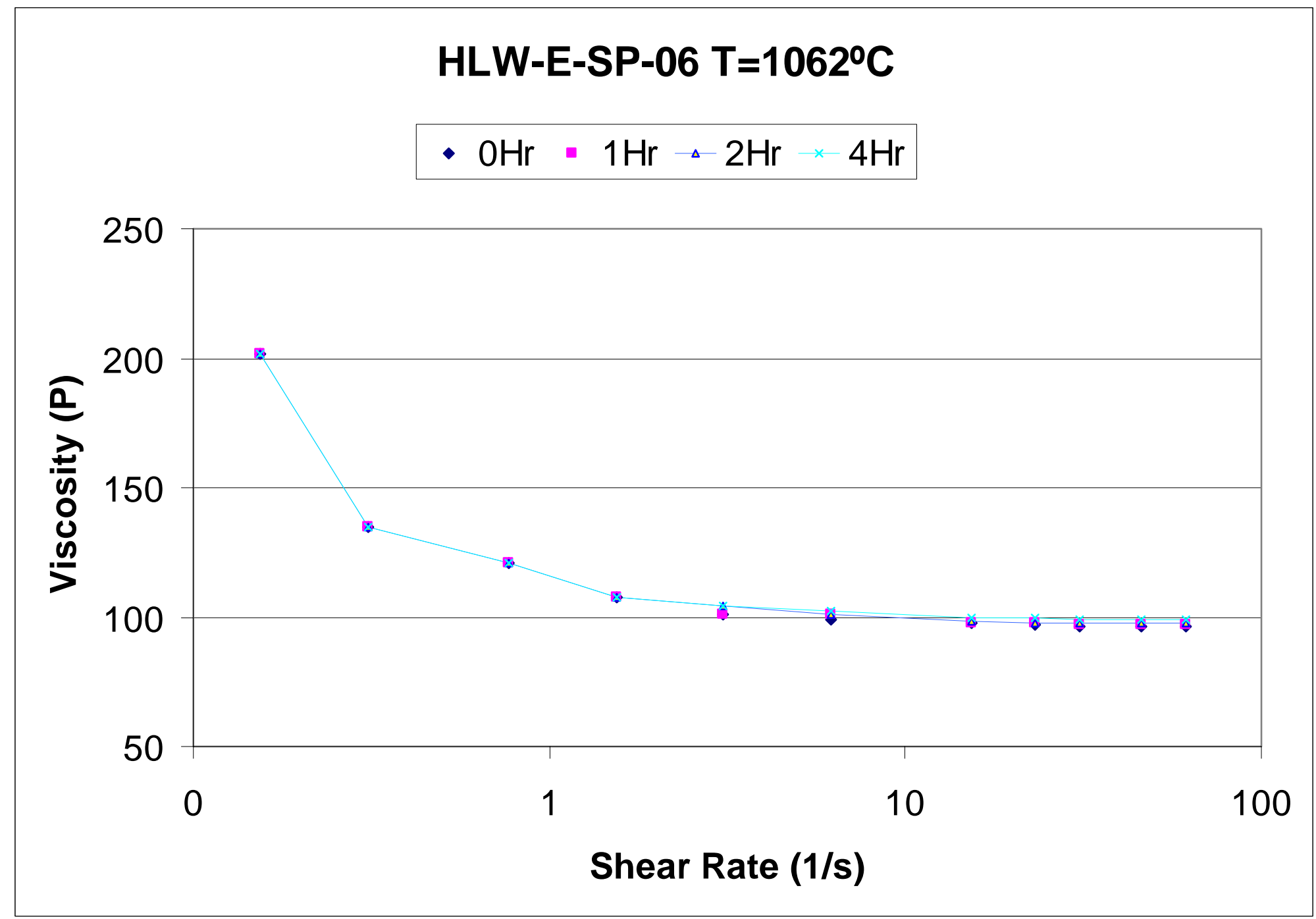

Figure 2.13b. Viscosity vs. shear rate for HLW-E-SP-06 at $1062^{\circ} \mathrm{C}$. (Uncertainty in viscosity measurement with this equipment is $\pm 10 \%$ ) 


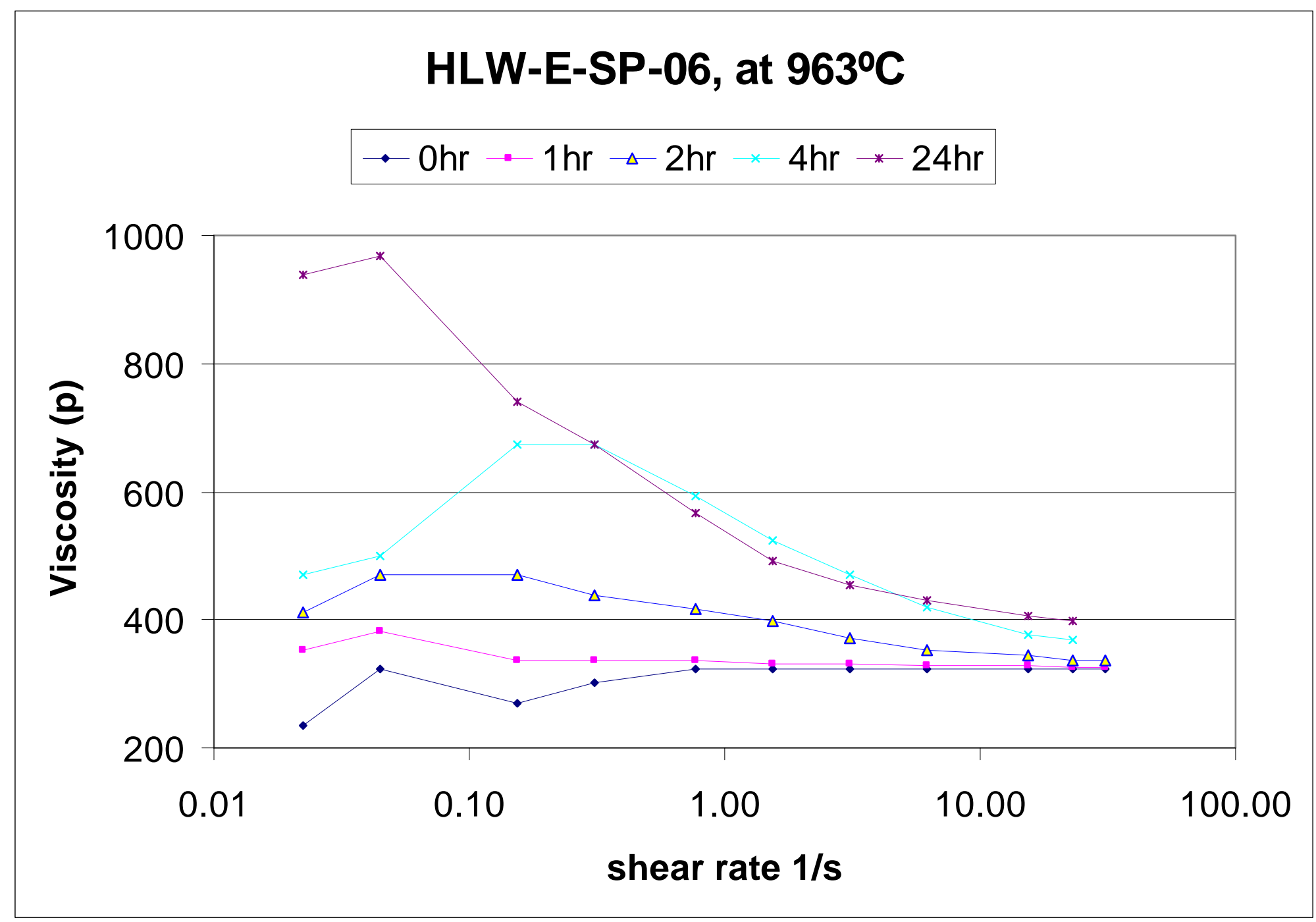

Figure 2.13c. Viscosity vs. shear rate for HLW-E-SP-06 at $963^{\circ} \mathrm{C}$.

(Uncertainty in viscosity measurement with this equipment is $\pm 10 \%$ ) 


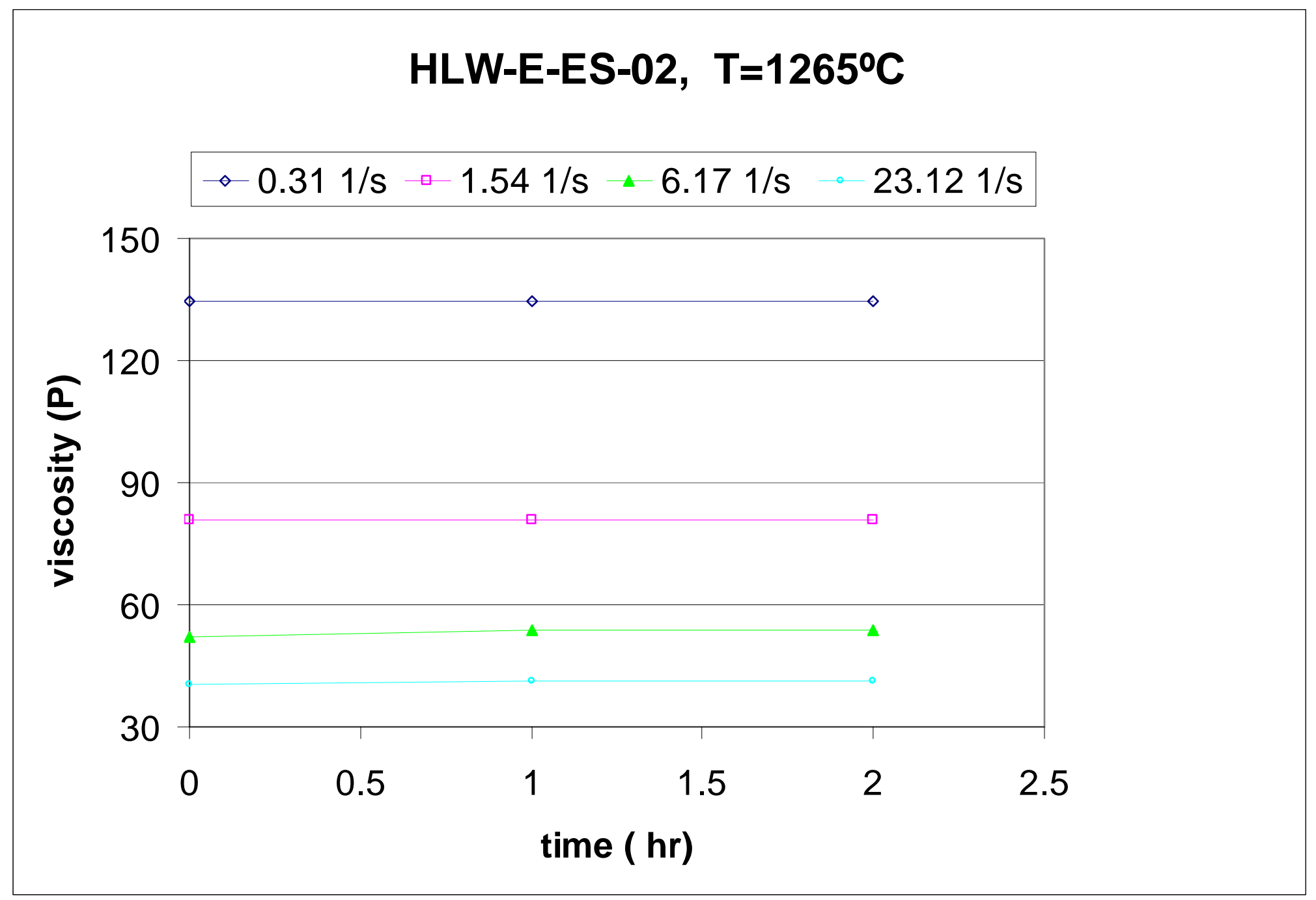

Figure 2.14a. Viscosity vs. dwell time for HLW-E-ES-02 at $1265^{\circ} \mathrm{C}$. (Uncertainty in viscosity measurement with this equipment is $\pm \mathbf{1 0} \%$ ) 


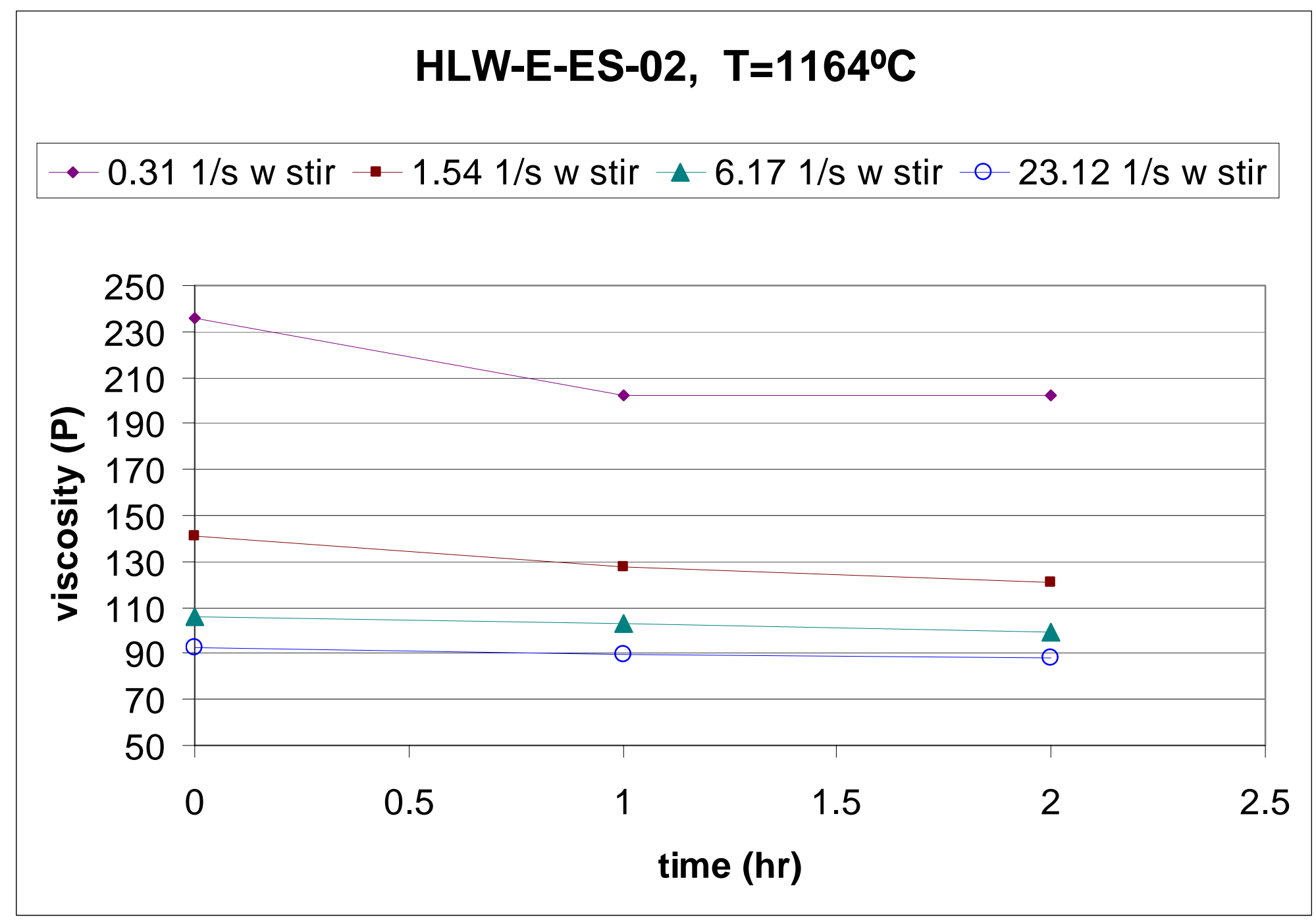

Figure 2.14b. Viscosity vs. dwell time for HLW-E-ES-02 $1164^{\circ} \mathrm{C}$. (Uncertainty in viscosity measurement with this equipment is $\pm \mathbf{1 0} \%$ ) 


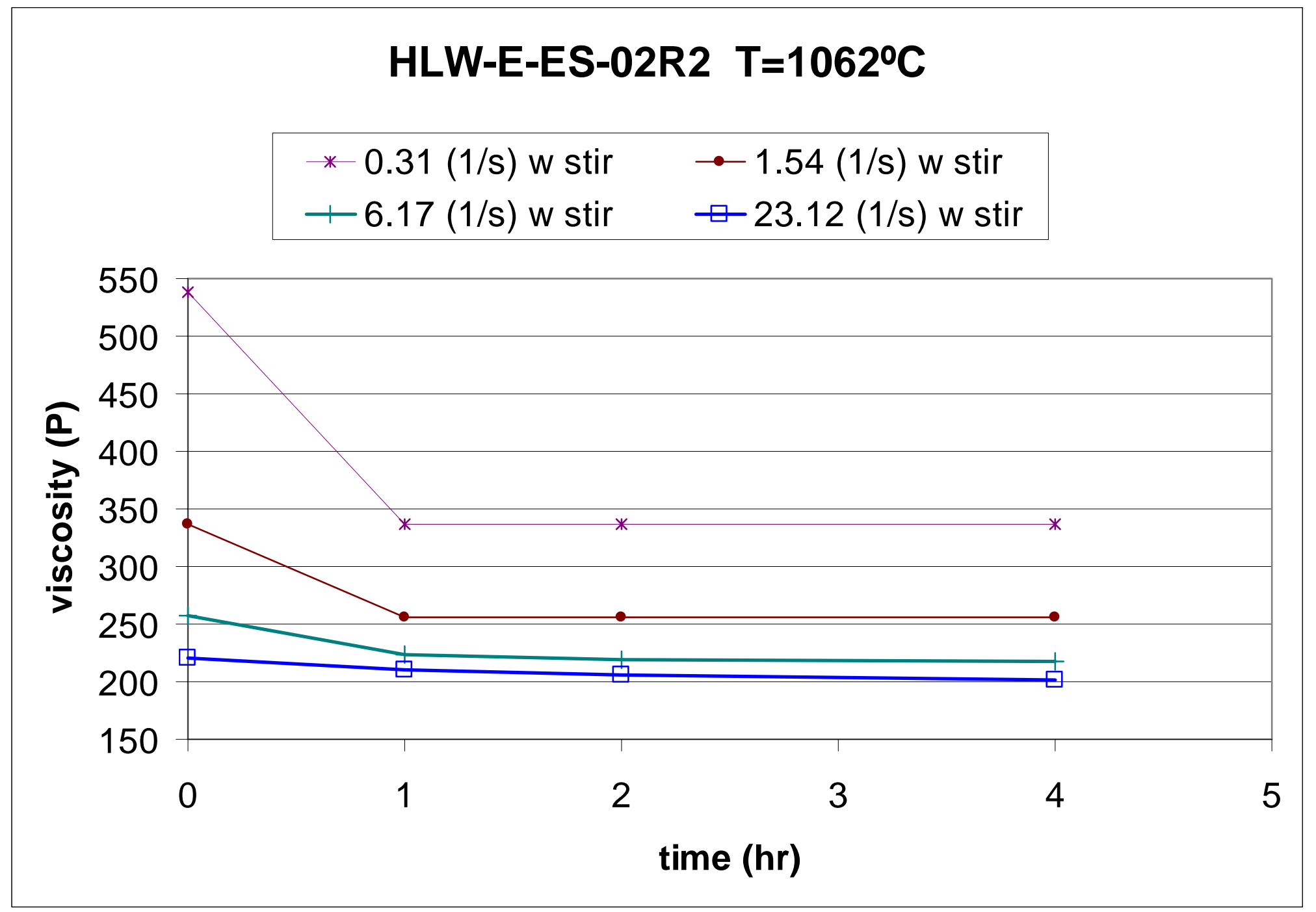

Figure 2.14c. Viscosity vs. dwell time for HLW-E-ES-02 at $1062^{\circ} \mathrm{C}$. (Uncertainty in viscosity measurement with this equipment is $\pm 10 \%$ ) 


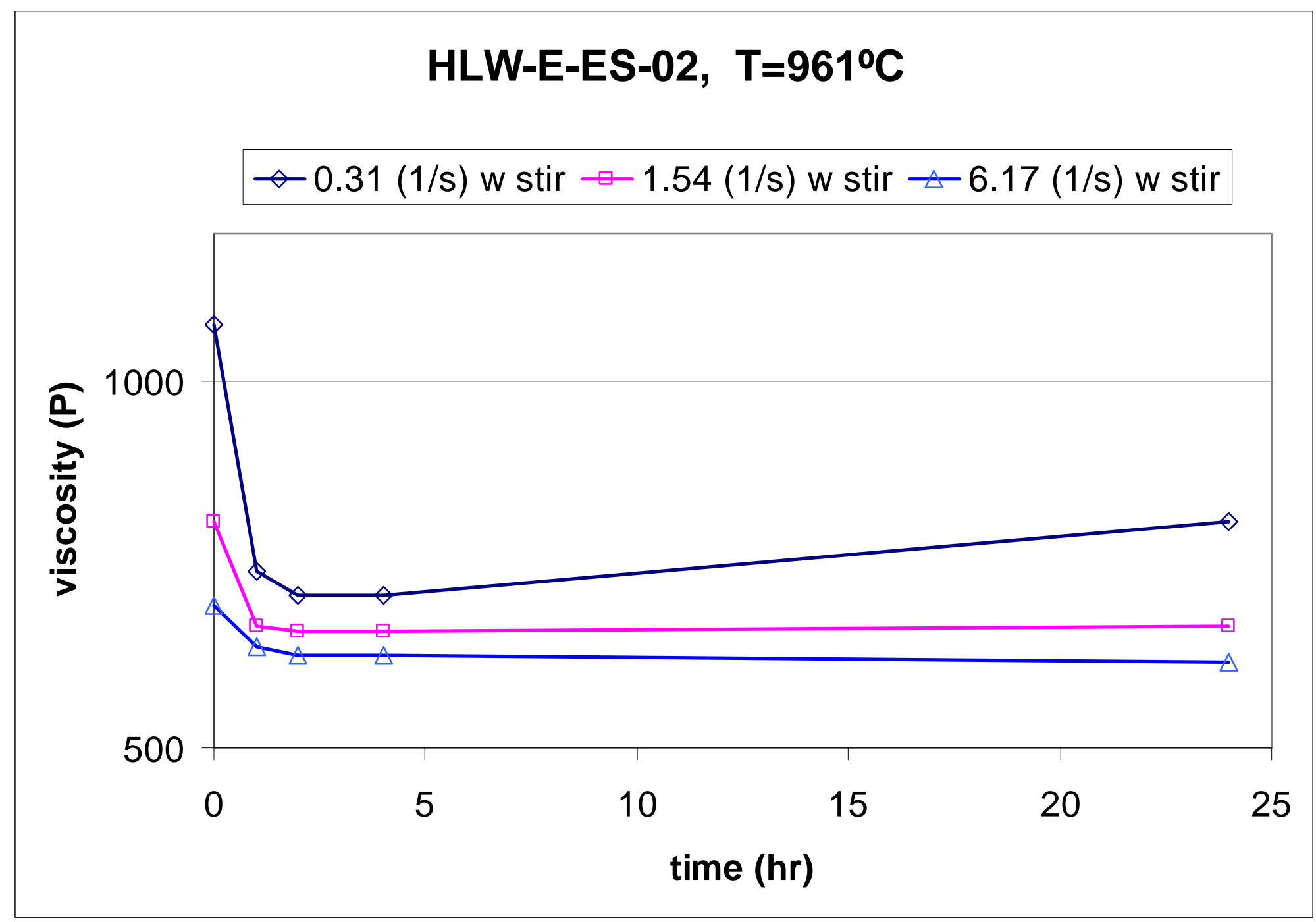

Figure 2.14d. Viscosity vs. dwell time for HLW-E-ES-02 at $961^{\circ} \mathrm{C}$. (Uncertainty in viscosity measurement with this equipment is $\pm 10 \%$ ) 


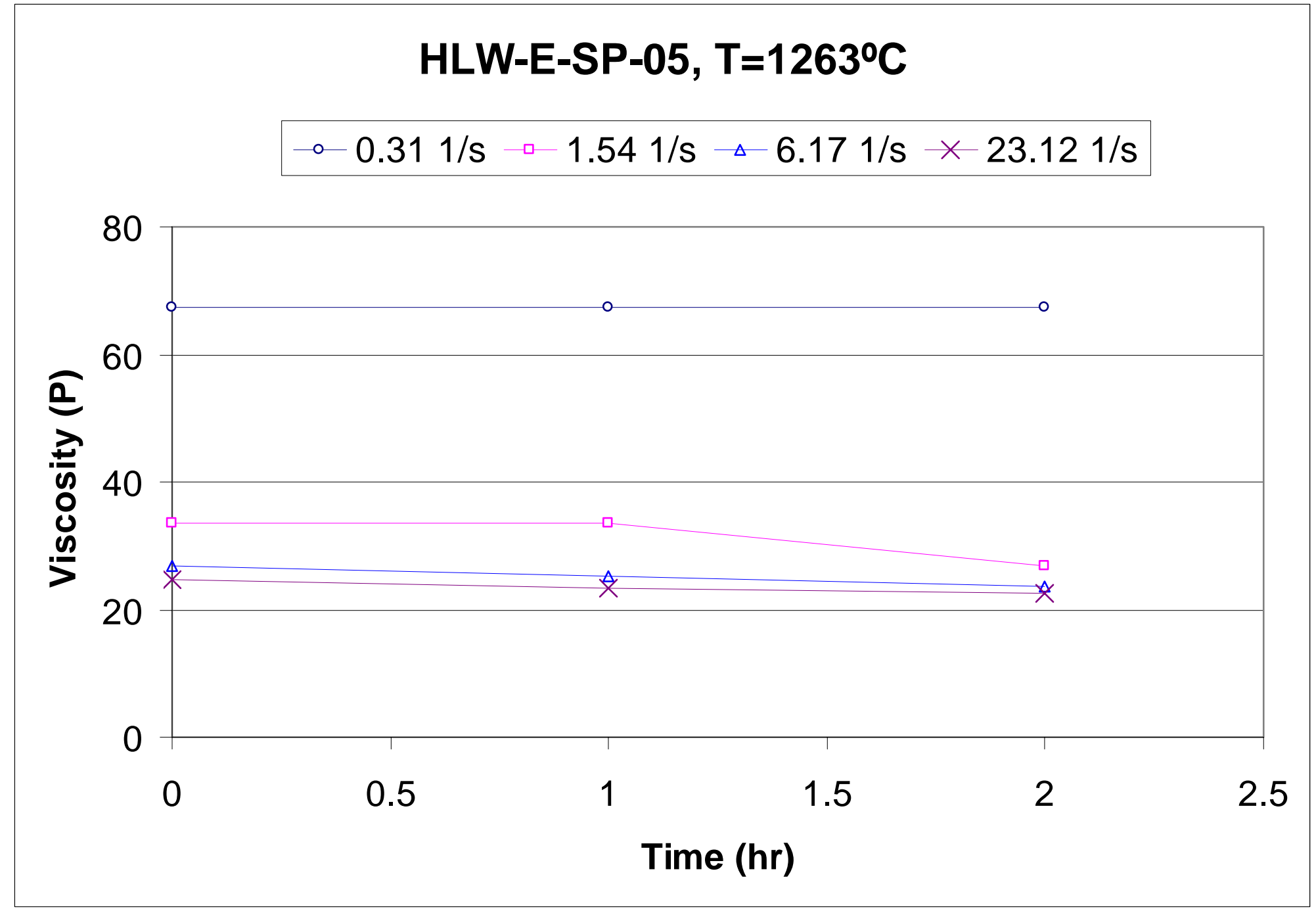

Figure 2.15a. Viscosity vs. dwell time for HLW-E-SP-05 at $1263^{\circ} \mathrm{C}$.

(Uncertainty in viscosity measurement with this equipment is $\pm 10 \%$ ) 


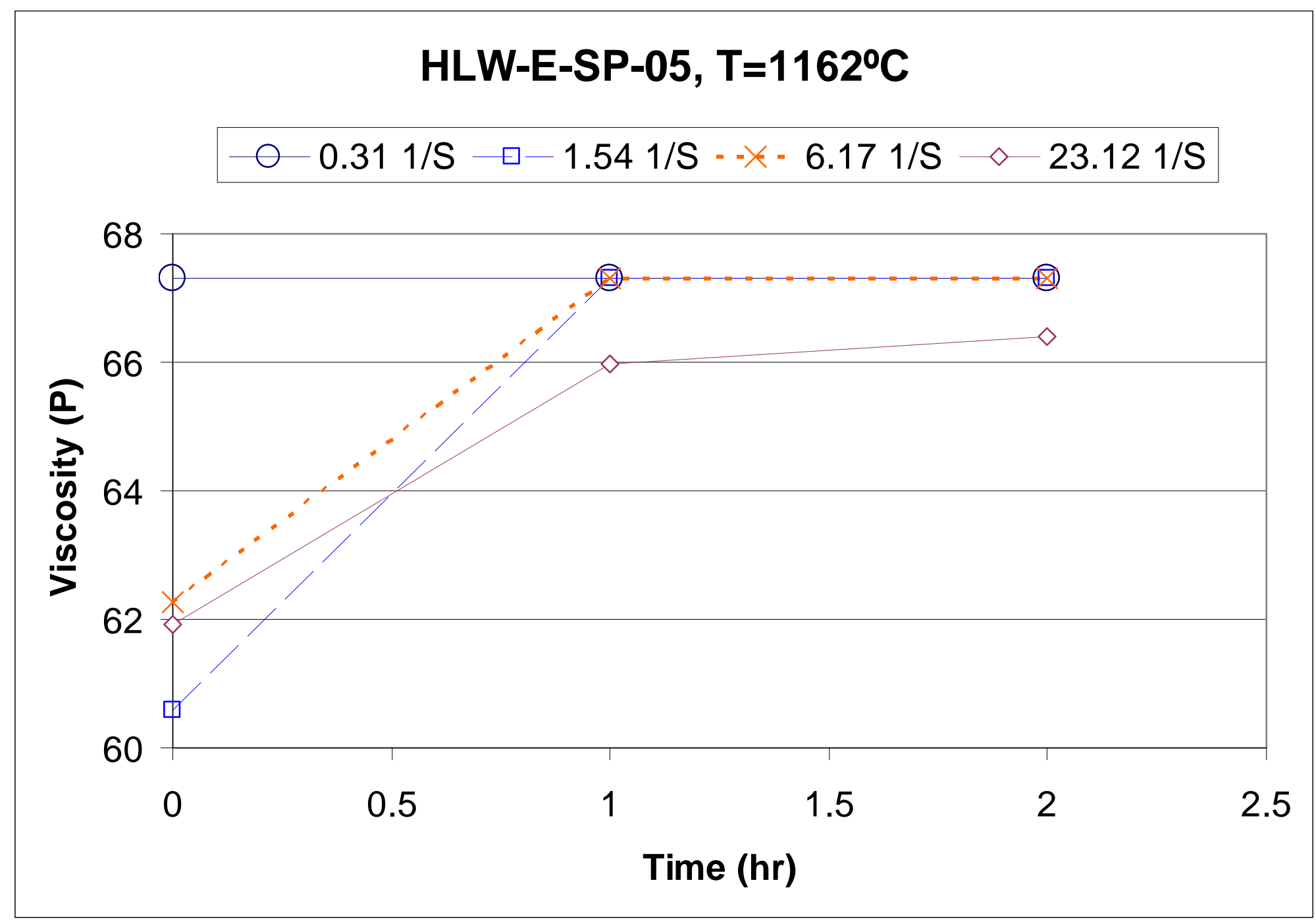

Figure 2.15b. Viscosity vs. dwell time for HLW-E-SP-05 at $1162^{\circ} \mathrm{C}$. (Uncertainty in viscosity measurement with this equipment is $\pm \mathbf{1 0 \%}$ ) 


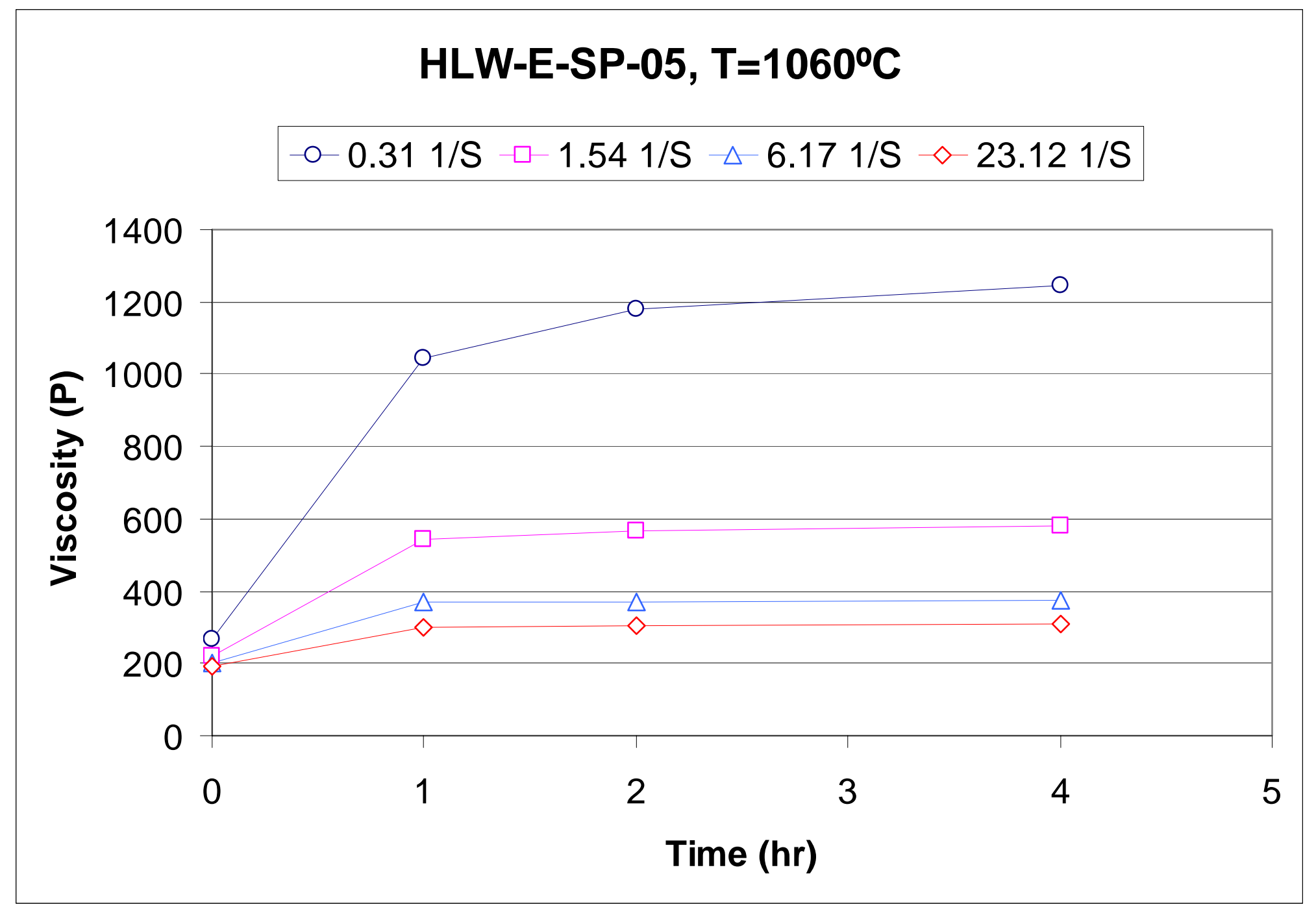

Figure 2.15c. Viscosity vs. dwell time for HLW-E-SP-05 $1060^{\circ} \mathrm{C}$.

(Uncertainty in viscosity measurement with this equipment is $\pm 10 \%$ ) 


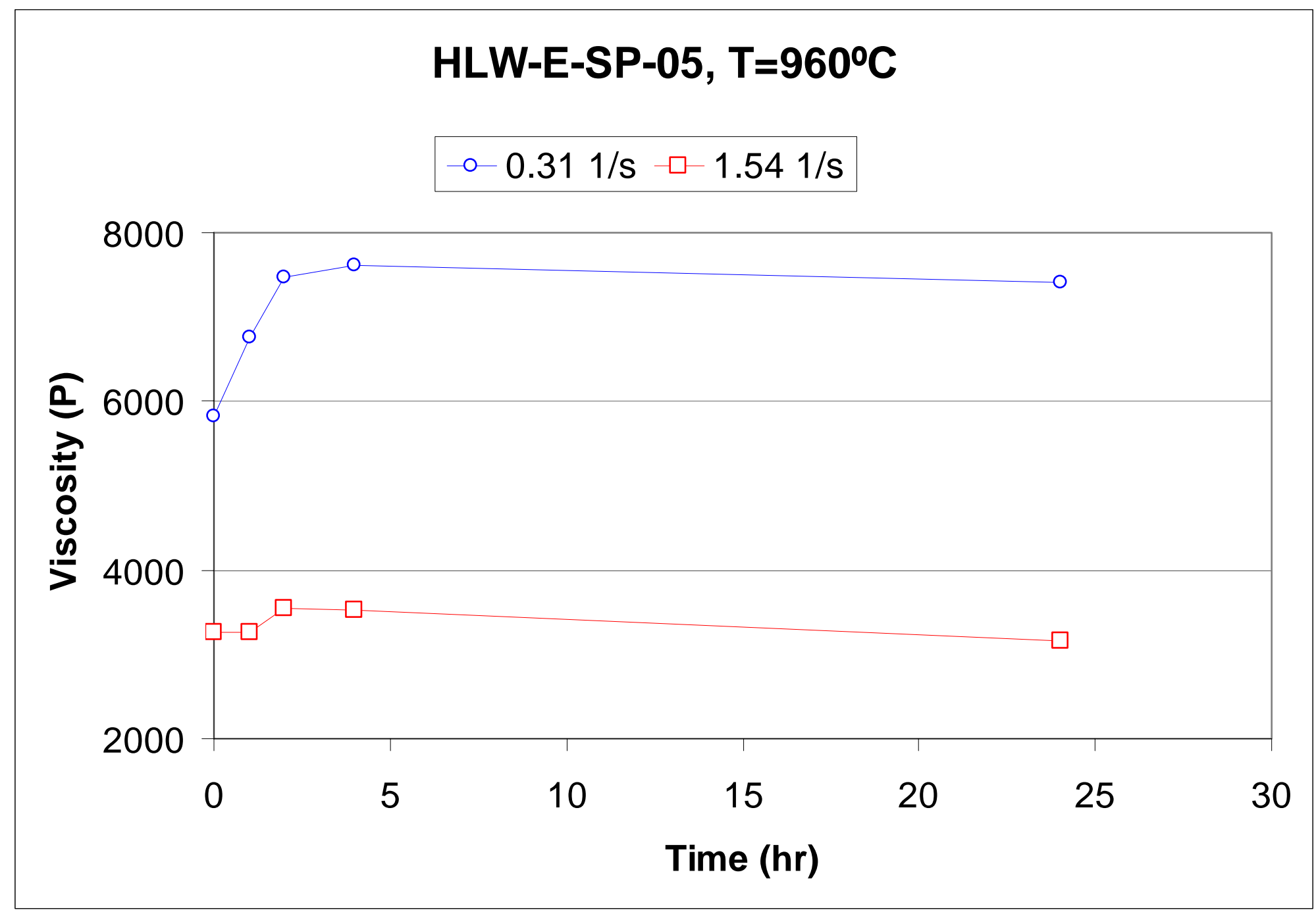

Figure 2.15d. Viscosity vs. dwell time for HLW-E-SP-05 at $960^{\circ} \mathrm{C}$.

(Uncertainty in viscosity measurement with this equipment is $\pm \mathbf{1 0} \%$ ) 


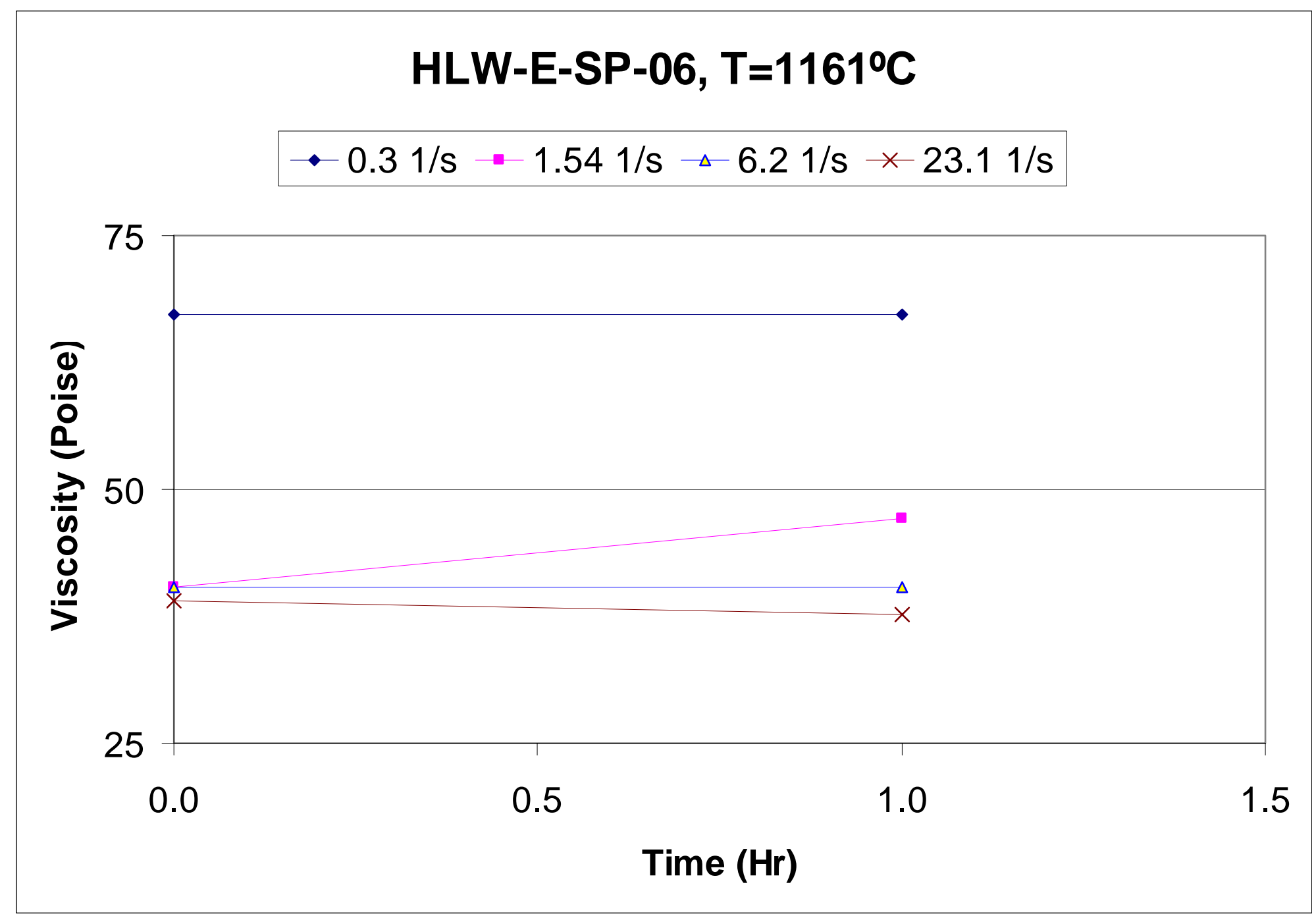

Figure 2.16a. Viscosity vs. dwell time for HLW-E-SP-06 at $1161^{\circ} \mathrm{C}$.

(Uncertainty in viscosity measurement with this equipment is $\pm 10 \%$ ) 


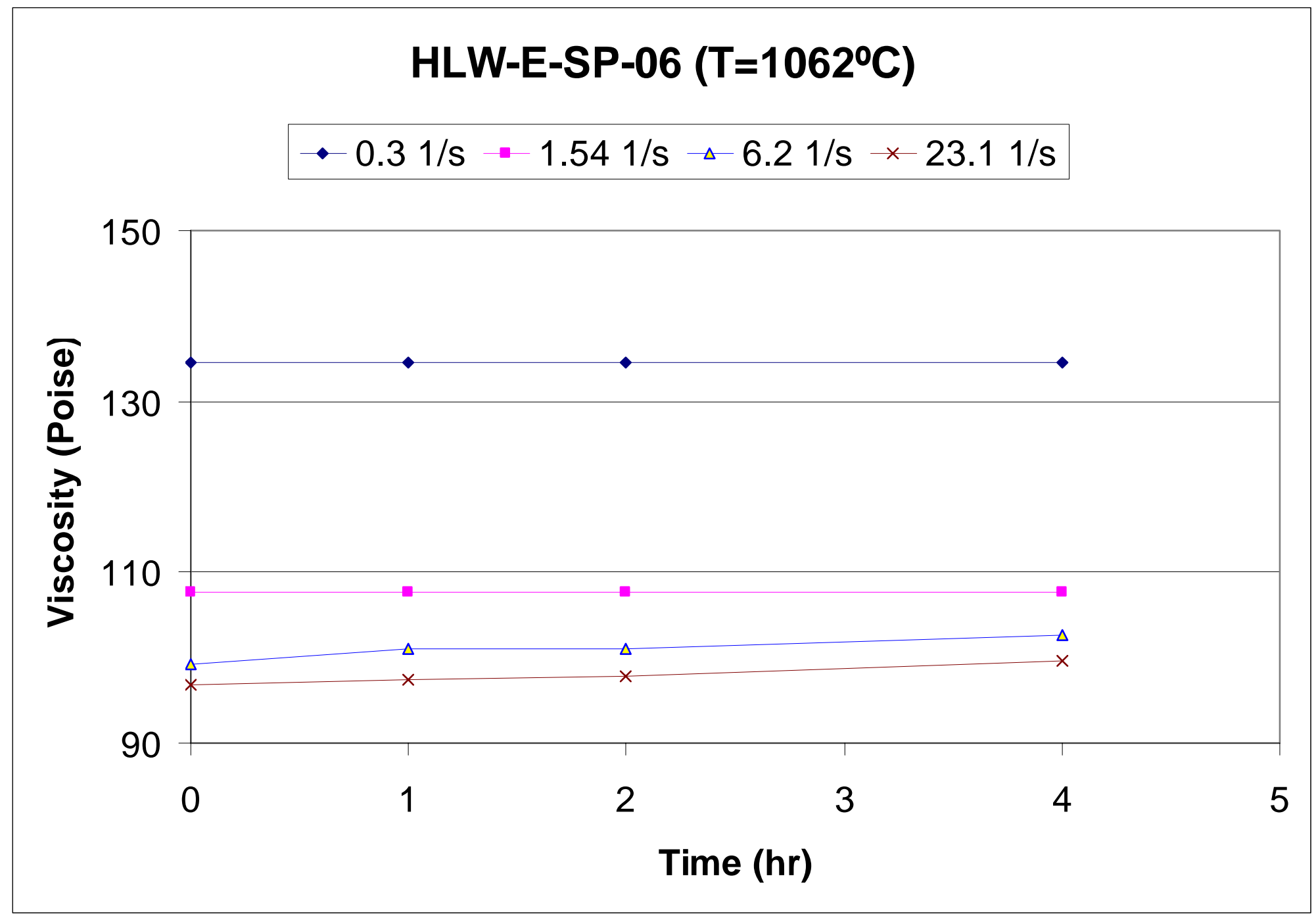

Figure 2.16b. Viscosity vs. dwell time for HLW-E-SP-06 at $1062^{\circ} \mathrm{C}$.

(Uncertainty in viscosity measurement with this equipment is $\pm 10 \%$ ) 


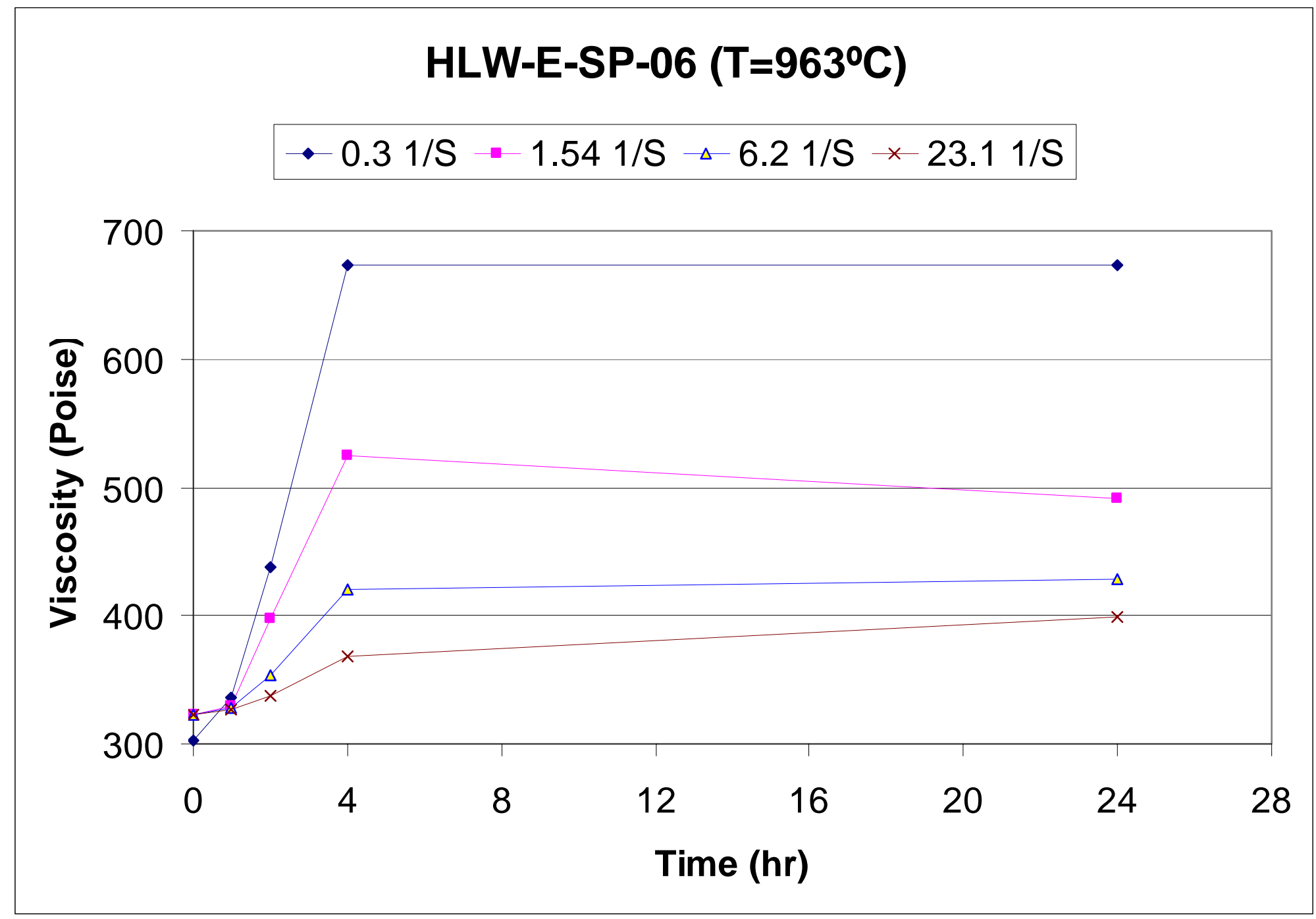

Figure 2.16c. Viscosity vs. dwell time for HLW-E-SP06 at $963^{\circ} \mathrm{C}$.

(Uncertainty in viscosity measurement with this equipment is $\pm \mathbf{1 0 \%}$ ) 

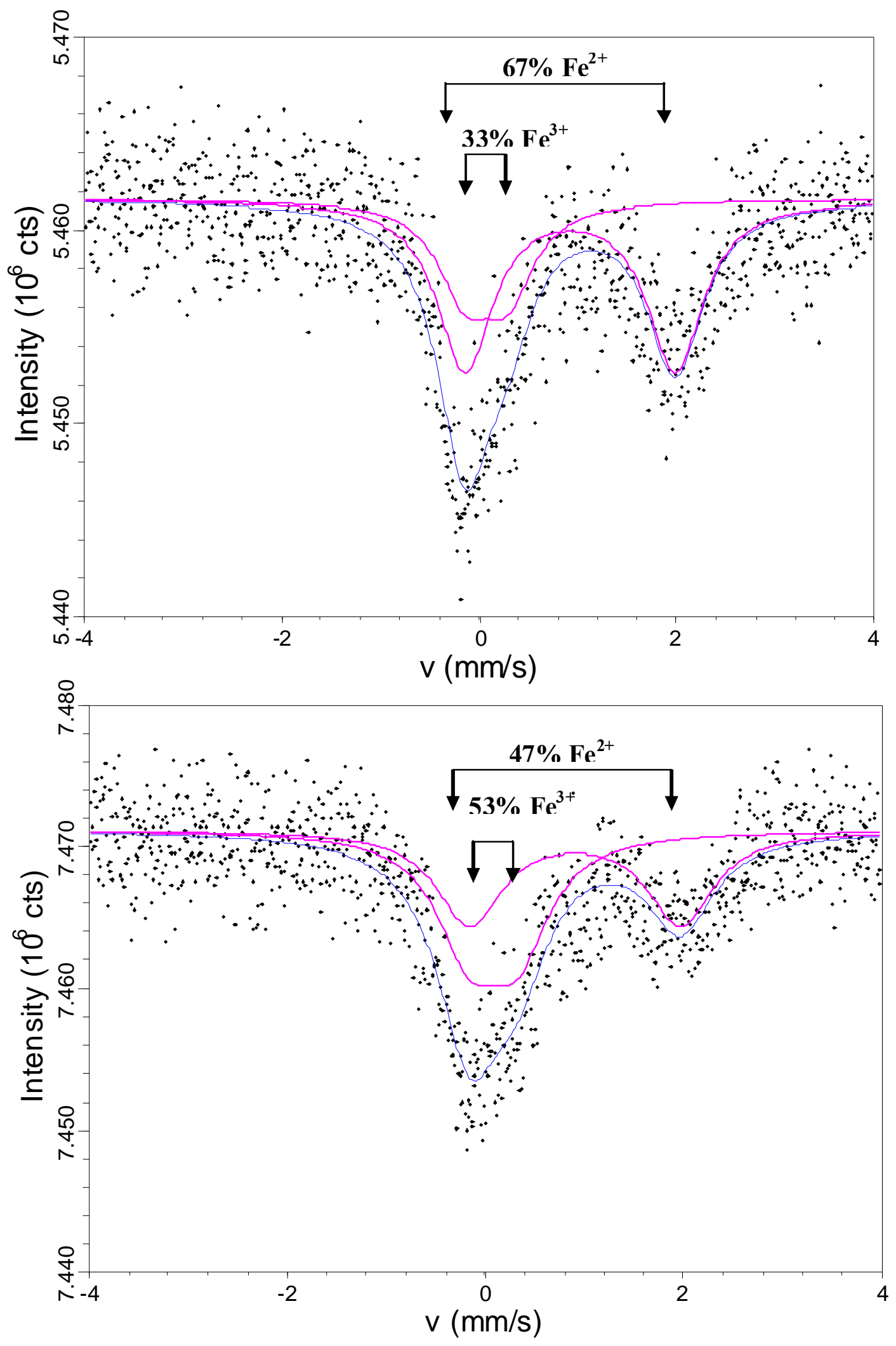

Figure 3.1. Iron Mössbauer spectra of glasses R10G155BRE6 (top) and DWVG123BRE2 (bottom). 


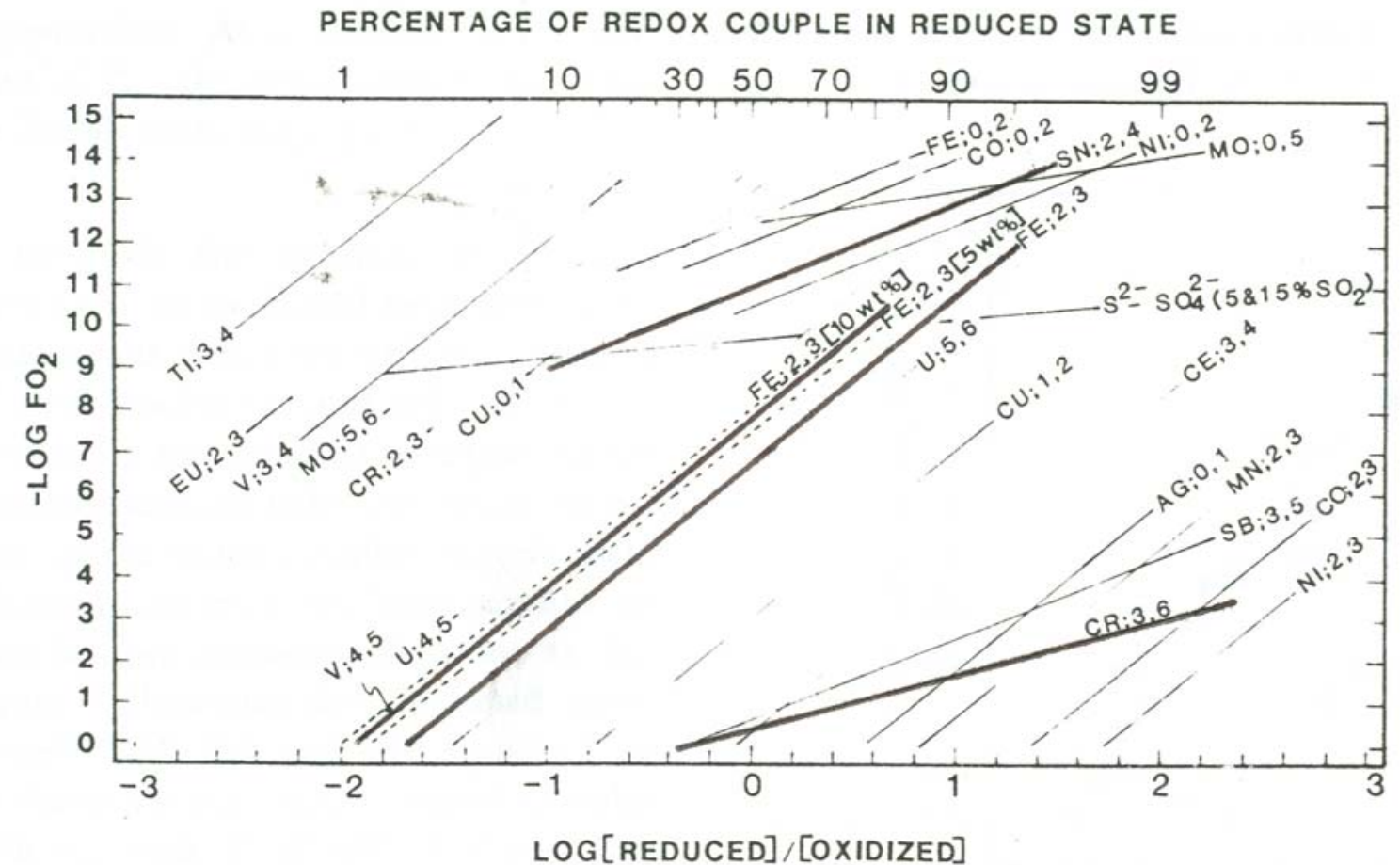

Fig. 2. Relation of imposed oxygen fugacity (as $-\log f_{\mathrm{O}_{2}}$ ) to analyzed redox ratio (as $\log$ [reduced ion]/[oxidized ion]) of multivalent elements doped into SRL-131 melt at $1150^{\circ} \mathrm{C}$. Dopant concentration is nominally about 1 wt \% except where noted. Experimental points were fitted to theoretical straight lines predicted by equation (11). Arabic numerals following element symbols for that relation represent oxidation states or numbers of the redox couple [Schreiber et al., 1983, 1986a, 1987].

Figure 3.2. $\mathrm{Cr}, \mathrm{Fe}, \mathrm{Sn}$, and $\mathrm{V}$ redox couples from Schreiber et al. [3-34]. 


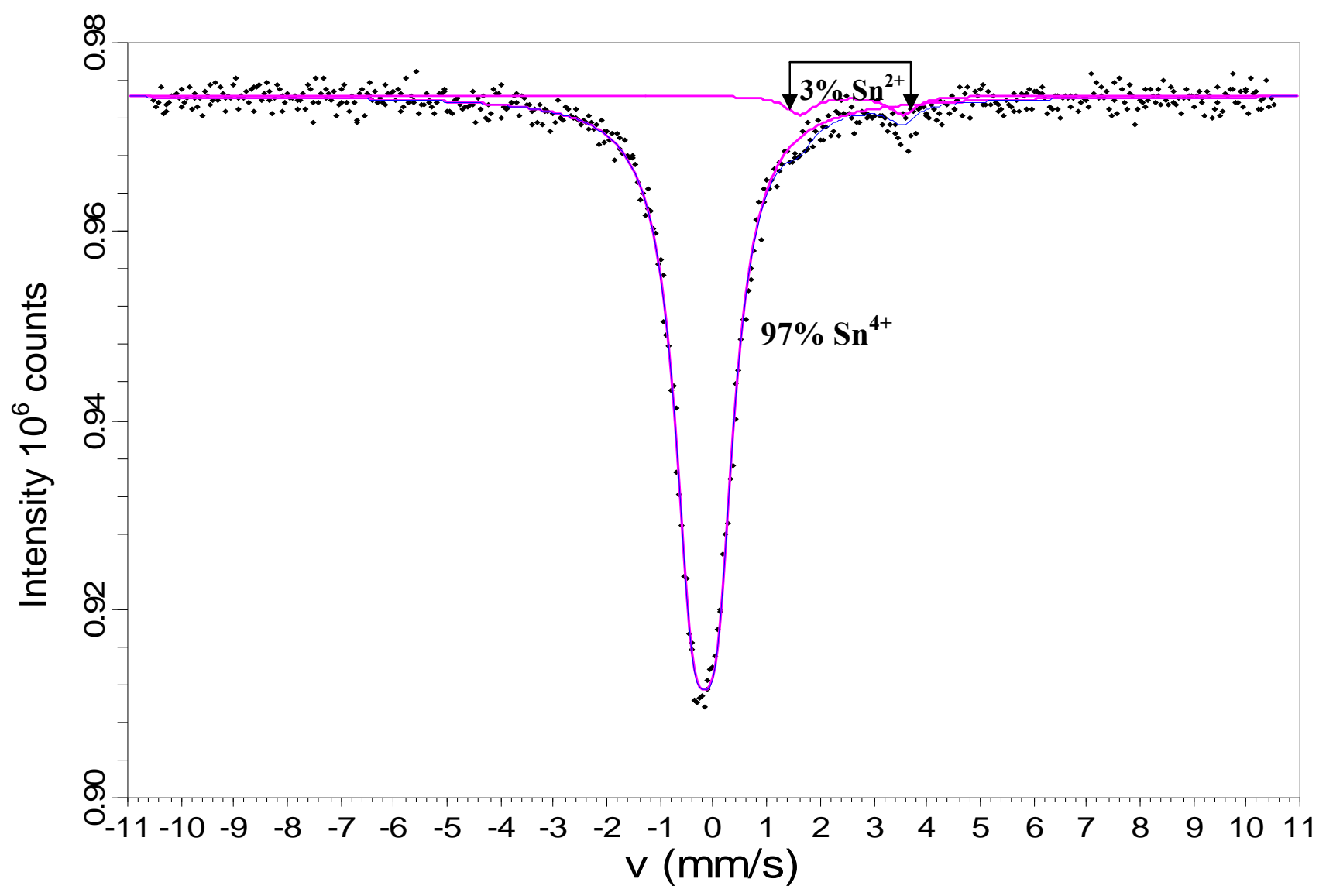

Figure 3.3. Tin Mössbauer spectrum of glass R10G155BRE8. 


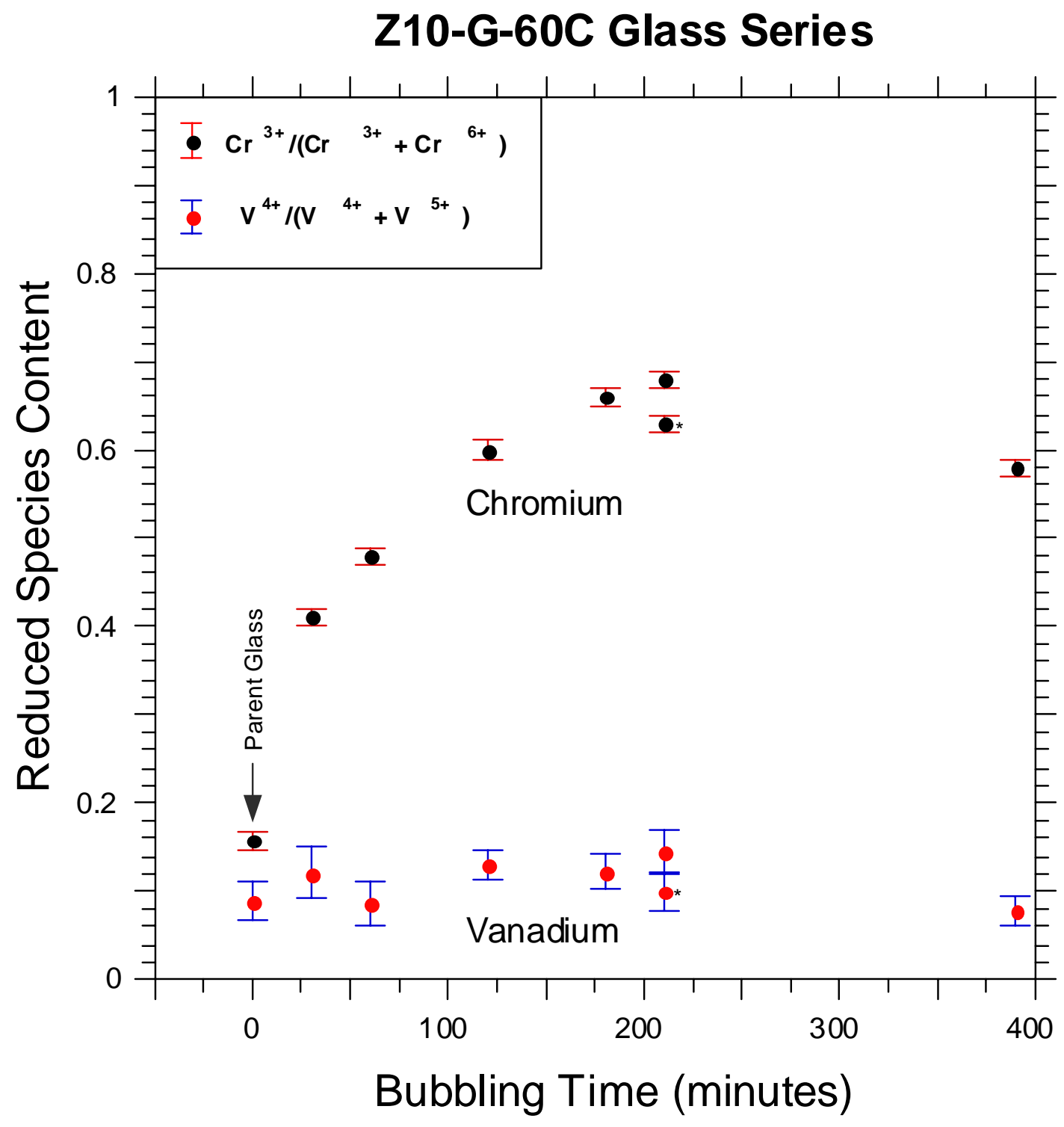

Figure 3.4. $\mathrm{V}$ and $\mathrm{Cr}$ reduction for the $\mathrm{Z10}-\mathrm{G}-60 \mathrm{C}$ glass versus $\mathrm{CO} / \mathrm{CO}_{2}$ bubbling time.

Uncertainties are shown as error bars. The asterisks indicate values for Z10G60CRE8 glass, where the parent glass melt was exposed to 210 minutes of continuous bubbling. 


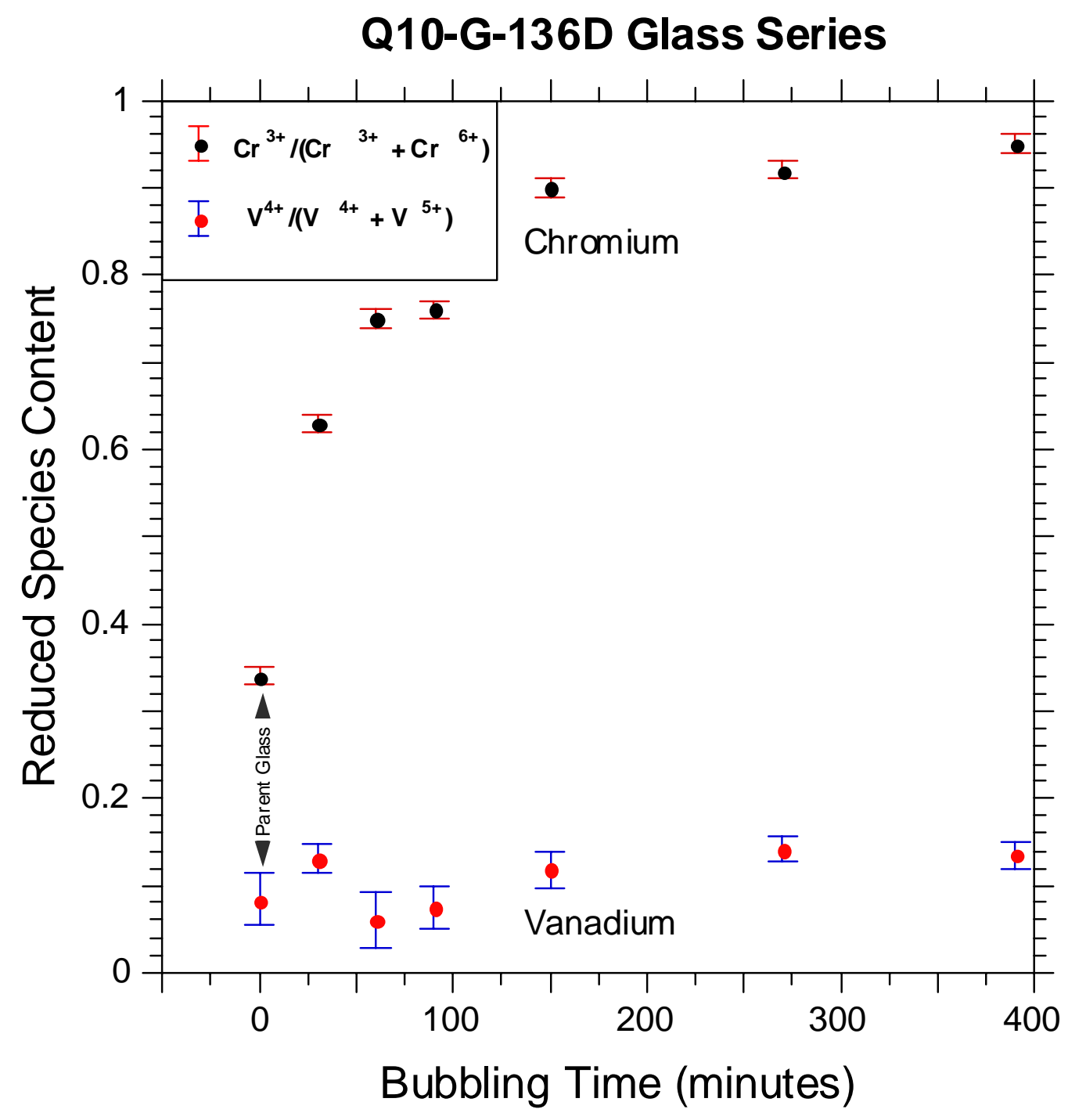

Figure 3.5. $\mathrm{V}$ and $\mathrm{Cr}$ reduction for the Q10-G-136D glasses versus $\mathrm{CO} / \mathrm{CO}_{2}$ bubbling time. All bubbling was done in 30 minute increments. Uncertainties are shown as error bars. 


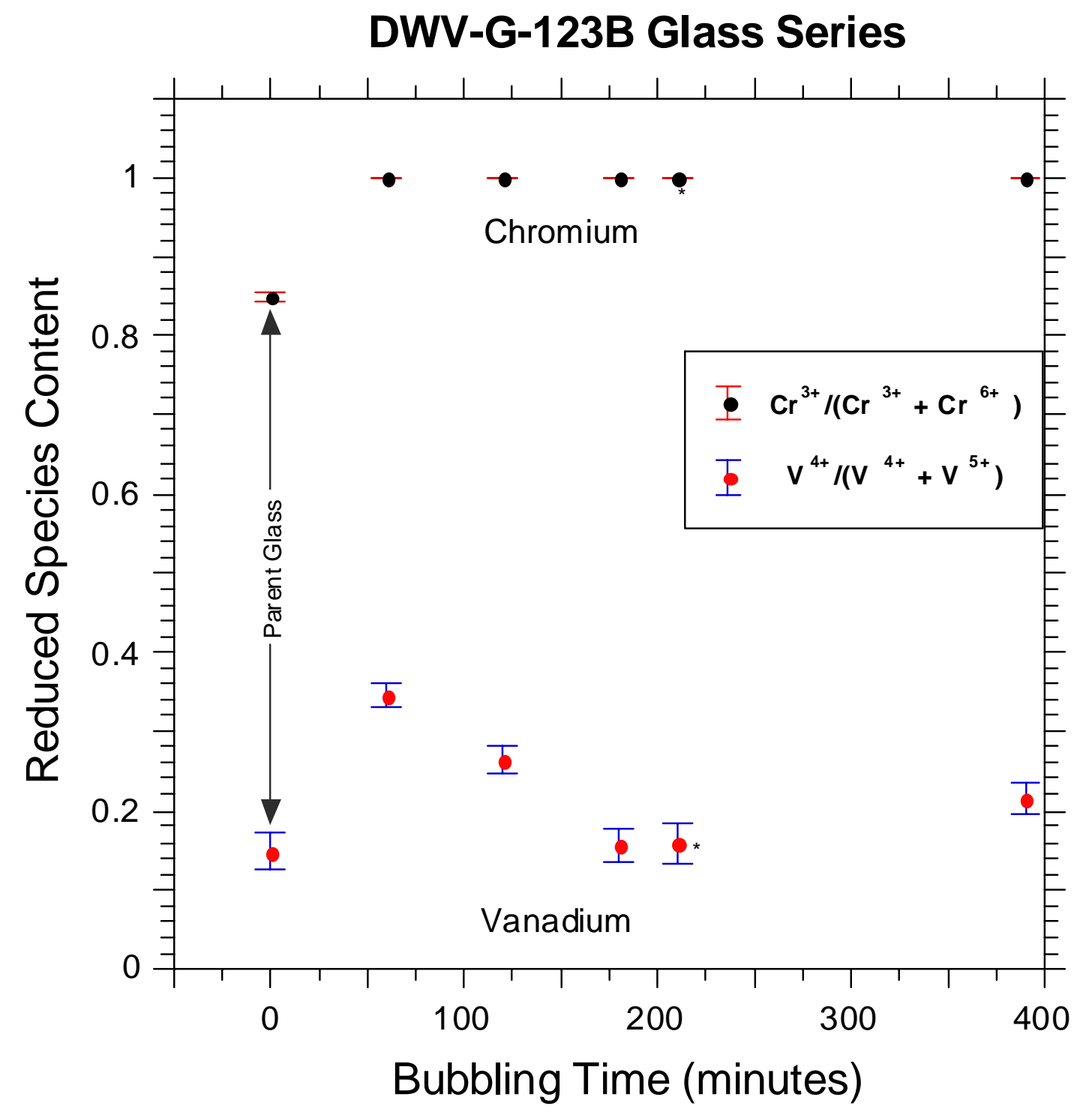

Figure 3.6. $\mathrm{V}$ and $\mathrm{Cr}$ reduction for the $\mathrm{DWV}-\mathrm{G}-123 \mathrm{~B}$ glasses versus $\mathrm{CO} / \mathrm{CO}_{2}$ bubbling time. Uncertainties are shown as error bars. The asterisks indicate values for DWVG123BRE8 glass, where the parent glass melt was exposed to 210 minutes of continuous bubbling. 


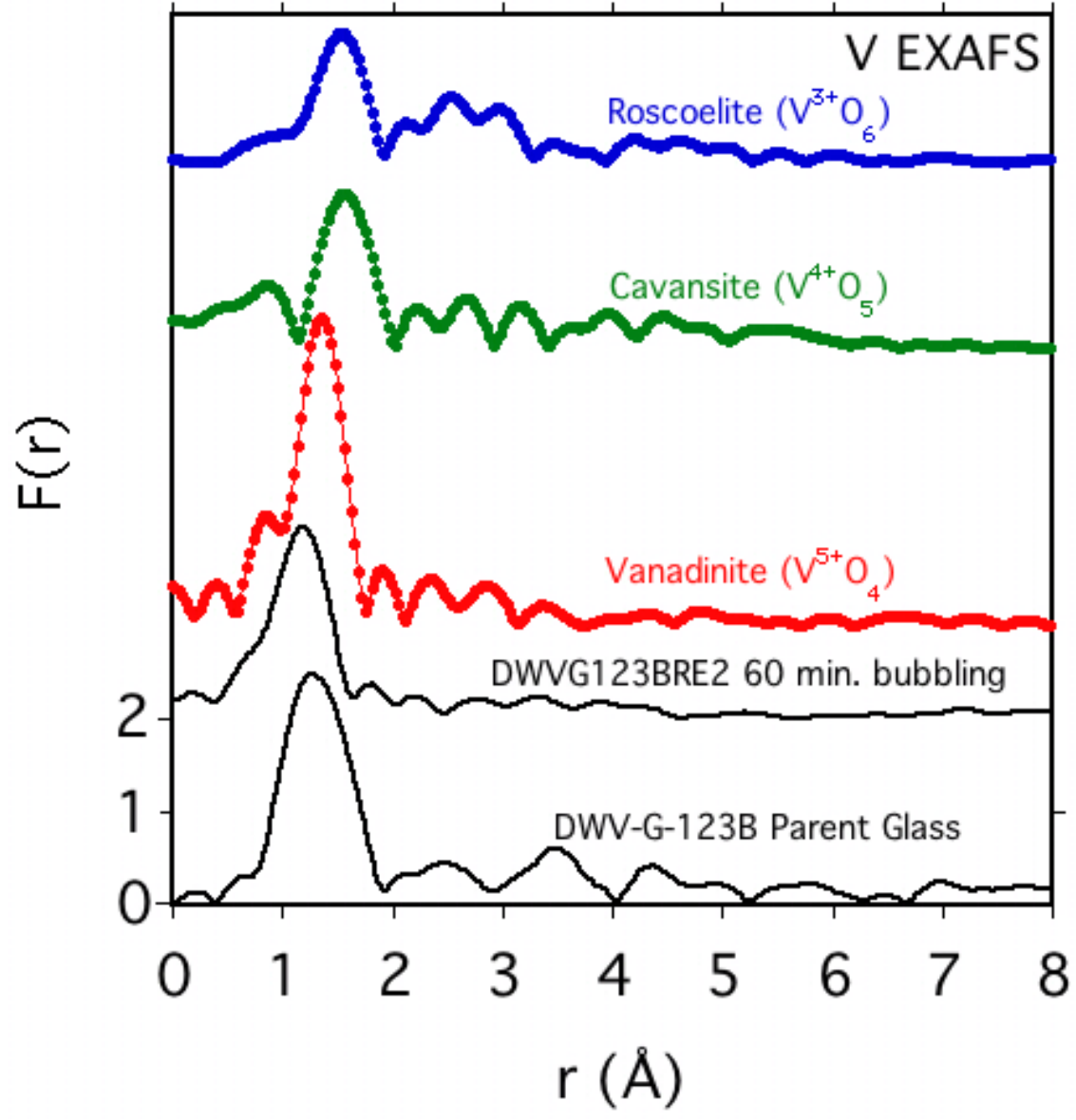

Figure 3.7. $V$ partial RDFs for the $\mathrm{V}^{5+}, \mathrm{V}^{4+}$, and $\mathrm{V}^{3+}$ standards and the parent and more reduced DWV-G-123B glasses. 


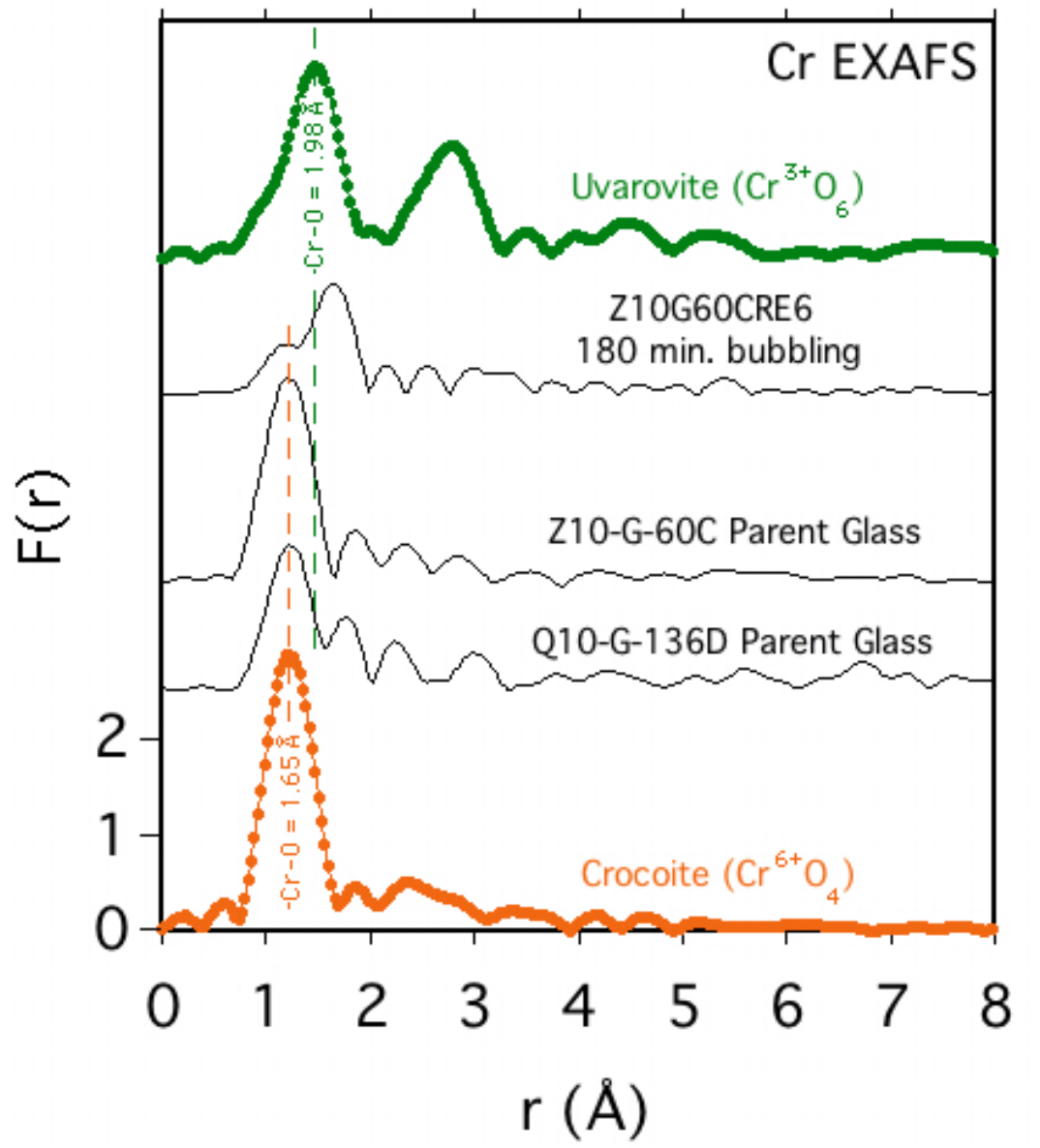

Figure 3.8. Cr partial RDFs for the $\mathrm{Cr}^{6+}$ and $\mathrm{Cr}^{3+}$ standards and three of the more $\mathrm{Cr}$-rich glasses studied. 


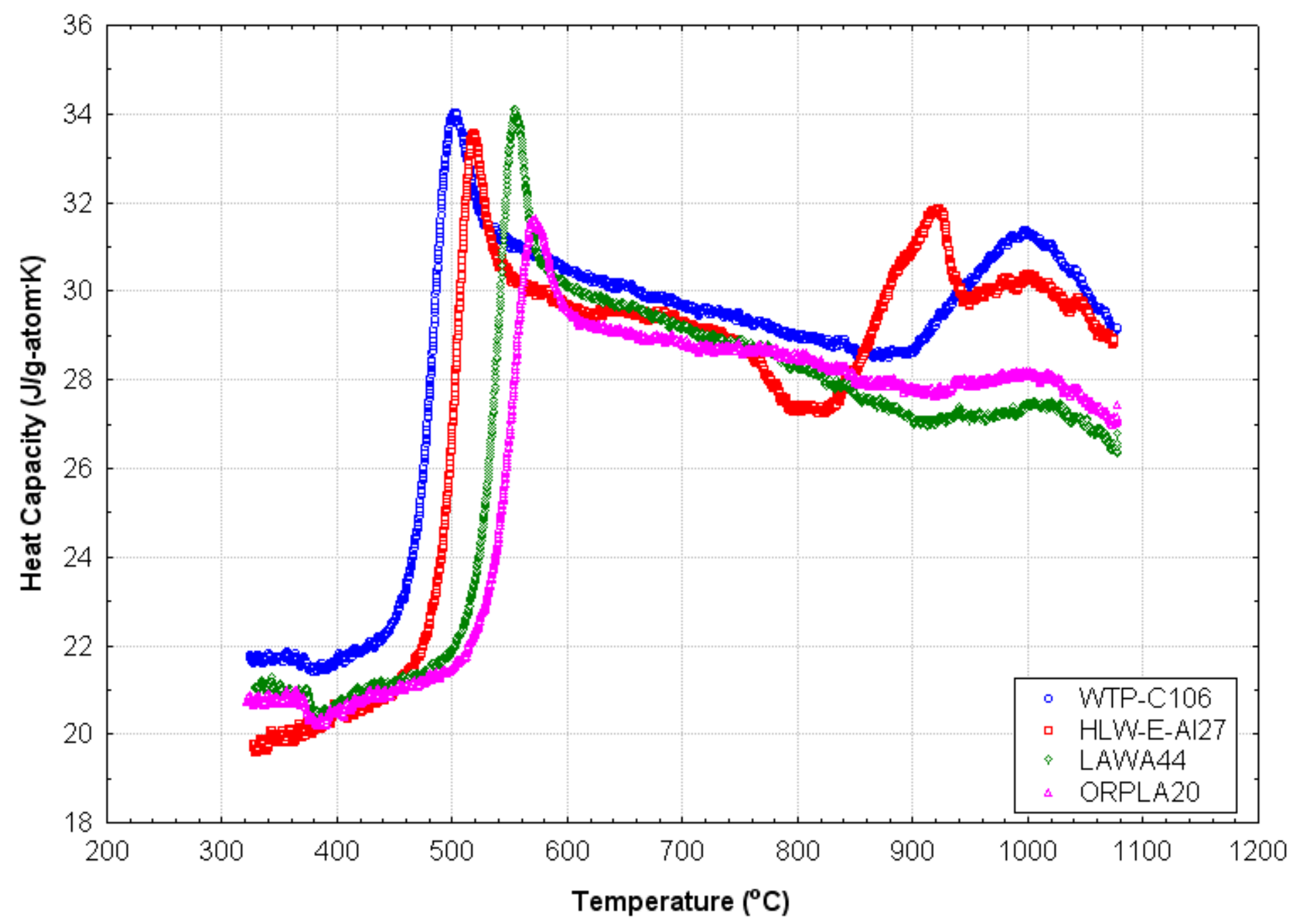

Figure 4.1. Specific heat of four simulated waste glasses/melts during heating $\left(5^{\circ} \mathrm{C} / \mathrm{minute}\right.$ in air). Note that the data are in units of $\mathbf{J} / \mathrm{g}$-atom.K.

(Uncertainty in specific heat measurement is estimated to be $\leq 0.1 \mathrm{~J} / \mathrm{g} \cdot \mathrm{K}$ ) 

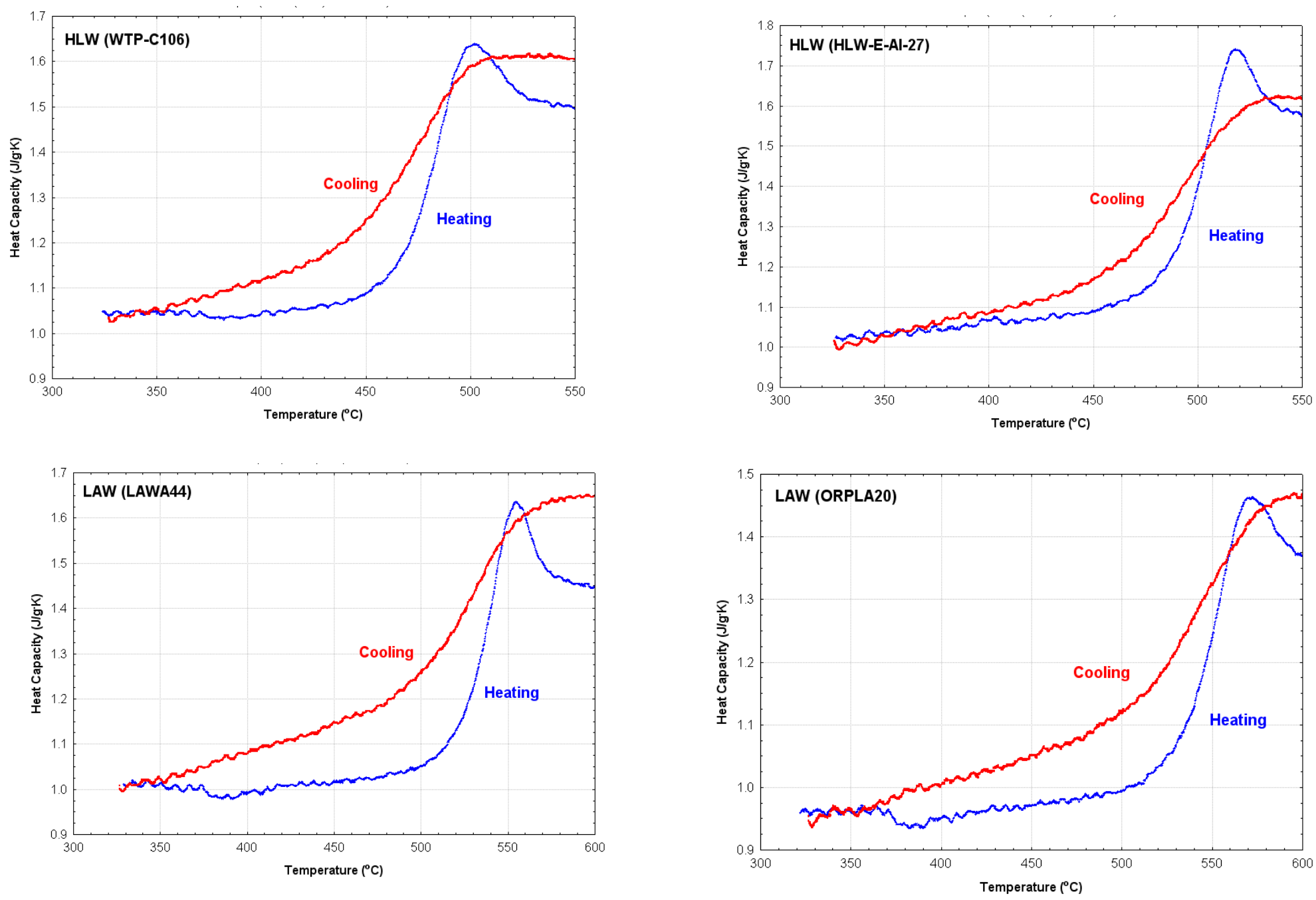

Figure 4.2. Specific heat of four simulated waste glasses/melts during heating and cooling near the glass transition $\left(5^{\circ} \mathrm{C} /\right.$ minute). Note that the data are in units of $\mathrm{J} / \mathrm{g} . \mathrm{K}$.

(Uncertainty in specific heat measurement is estimated to be $\leq 0.1 \mathrm{~J} / \mathrm{g} \cdot \mathrm{K}$ ) 


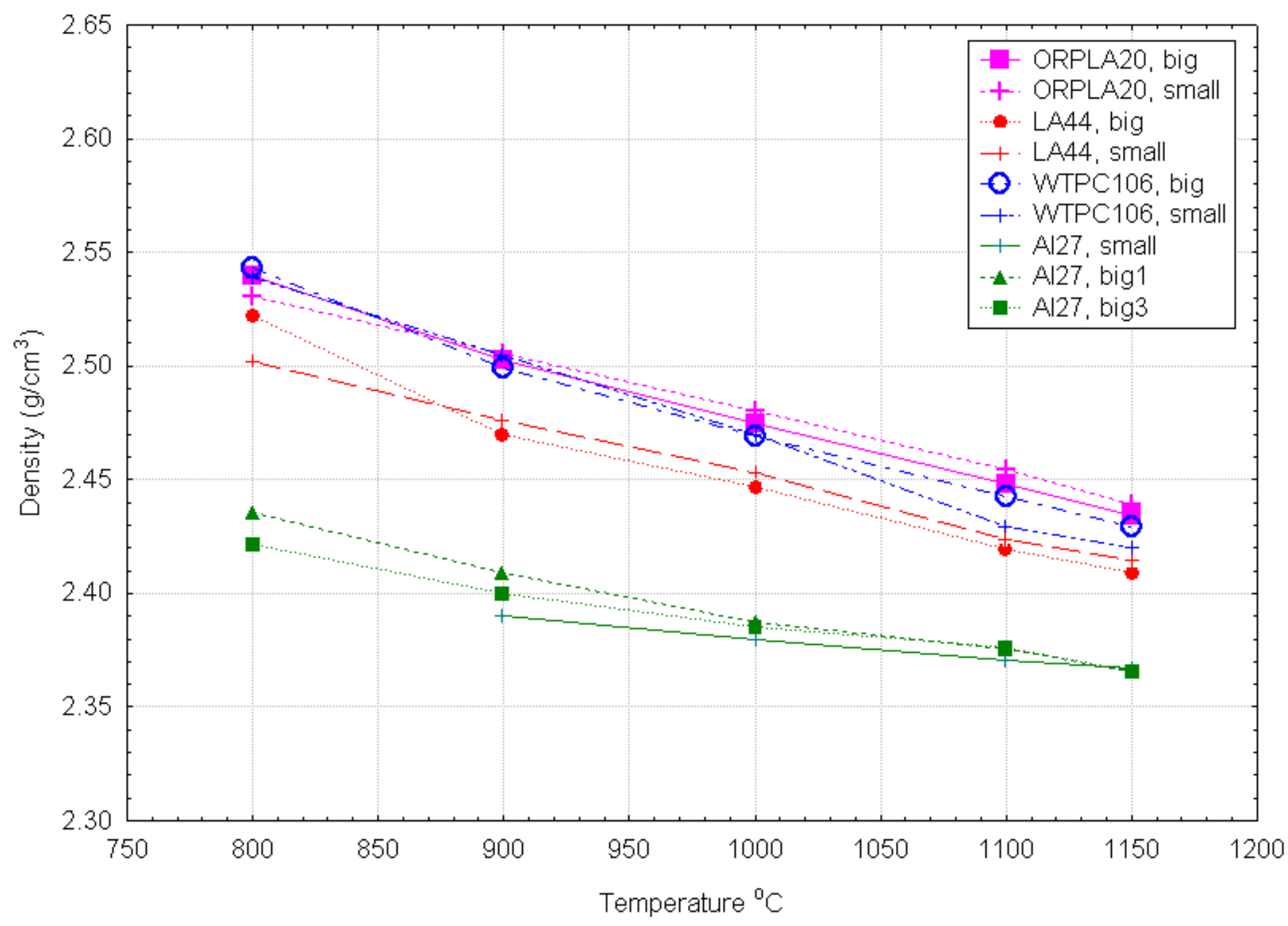

Figure 4.3. Density of four simulated waste glass melts. The lines are simply to guide the eye. (Uncertainty in density measurement is estimated to be $\leq 0.01 \mathrm{~g} / \mathrm{cm}^{3}$ ) 


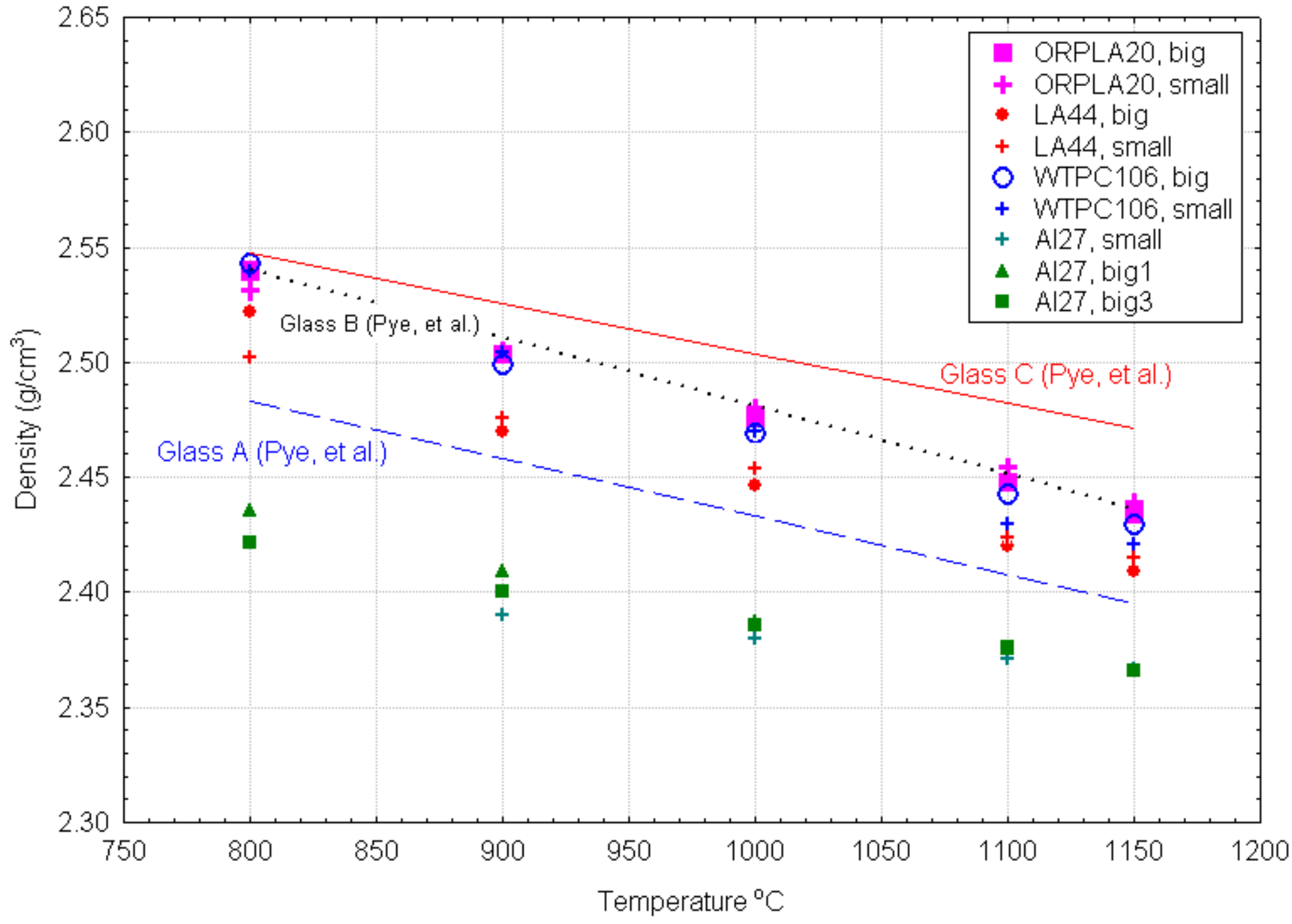

Figure 4.4. Density of four simulated waste glass melts and comparison to density data for three simulated waste glass melts from regression equations provided by Pye et al. [4-5].

(Uncertainty in density measurement is estimated to be $\leq 0.01 \mathrm{~g} / \mathrm{cm}^{3}$ ) 


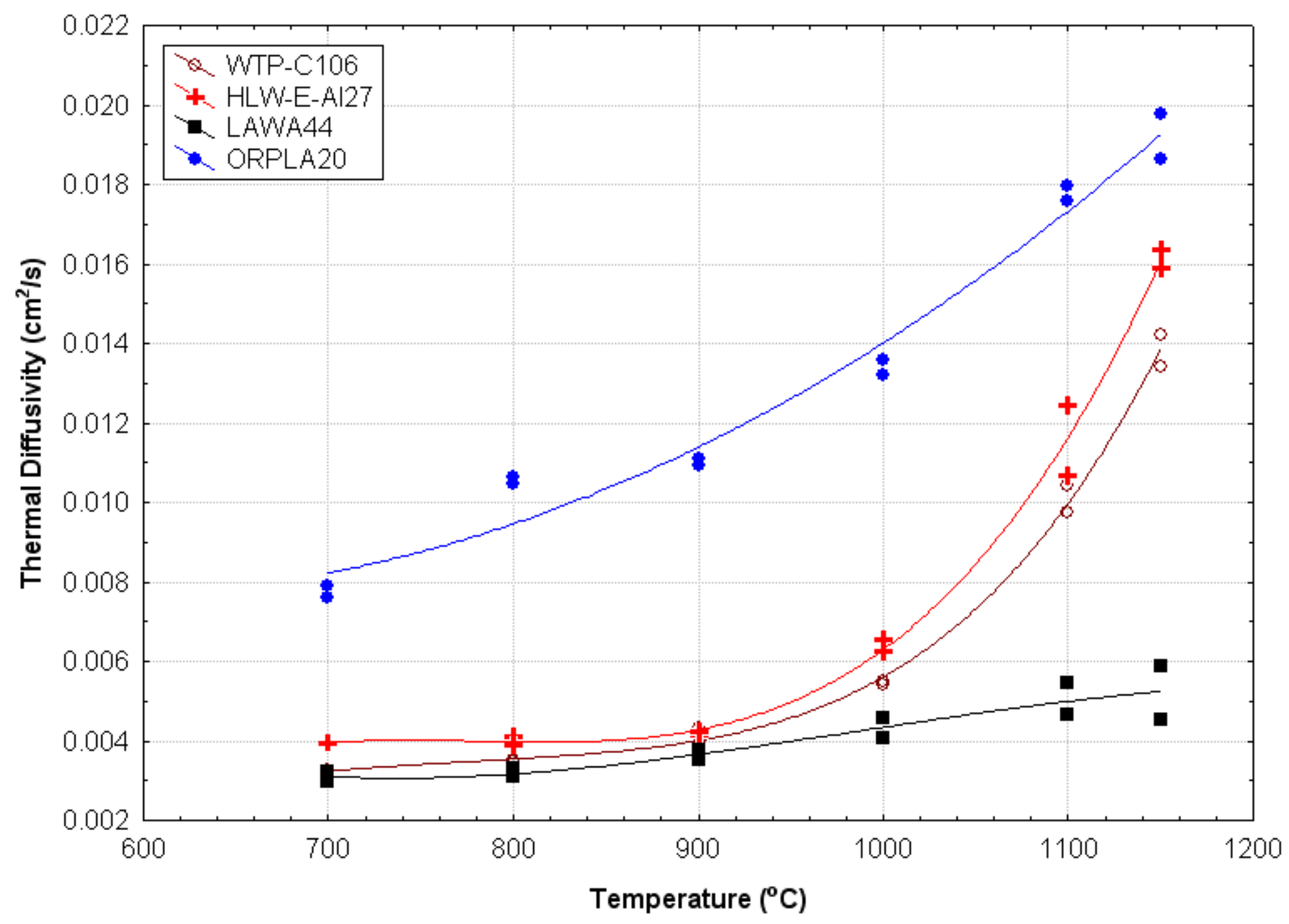

Figure 4.5. Thermal diffusivity of four simulated waste glass melts. Multiple points for a melt sample at a given temperature are from separate experiments using heat waves of different periods. Curves are polynomial fits.

(Uncertainty in thermal diffusivity measurement is estimated to $b e \leq 0.001 \mathrm{~cm}^{2} / \mathrm{s}$ ) 


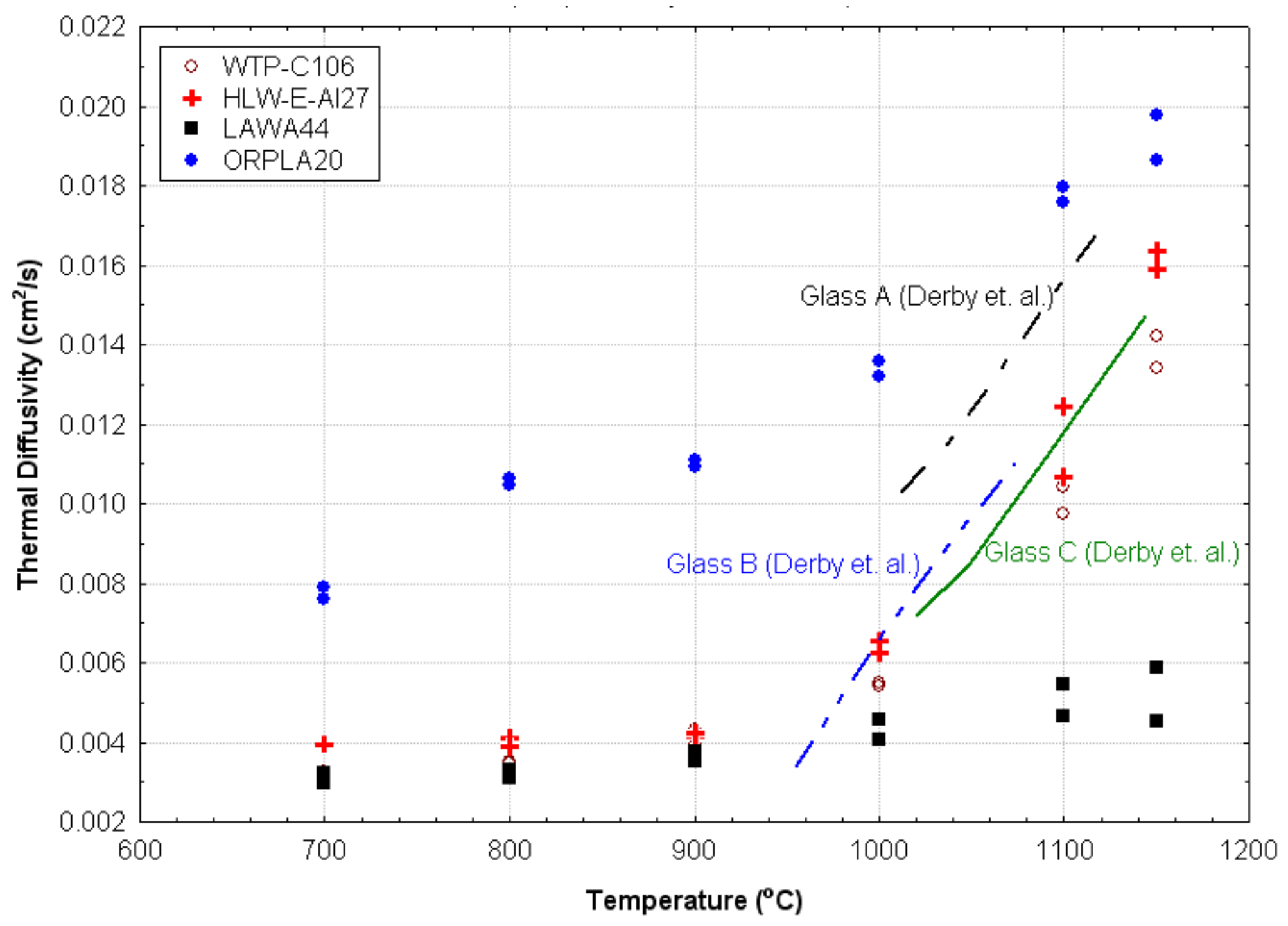

Figure 4.6. Thermal diffusivity of four simulated waste glass melts in comparison to data for three simulated waste glass melts by Derby et al. [4-20].

(Uncertainty in thermal diffusivity measurement is estimated to be $\leq 0.001 \mathrm{~cm}^{2} / \mathrm{s}$ ) 


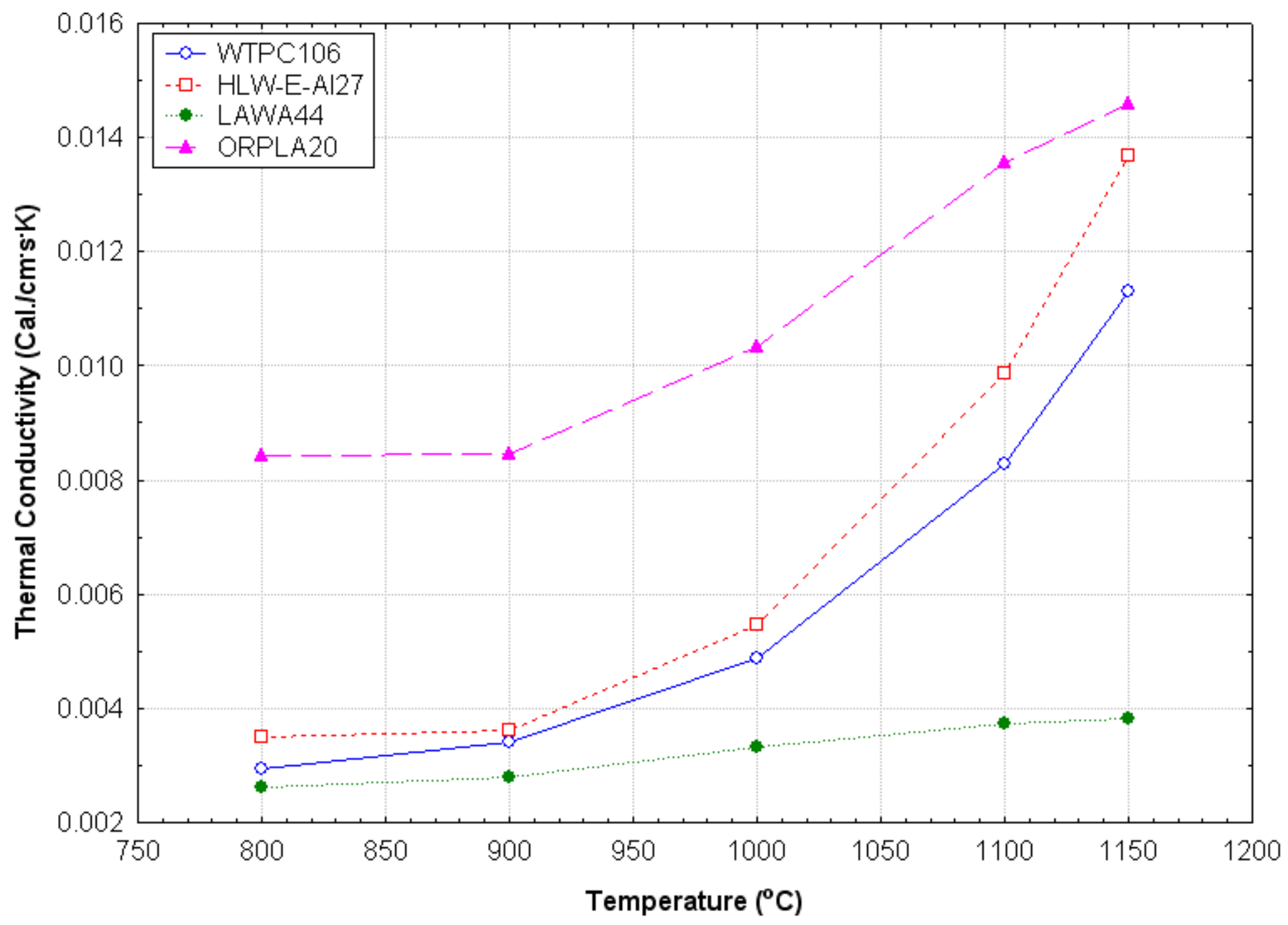

Figure 4.7. Thermal conductivity of four simulated waste glass melts calculated from the average data for specific heat, density, and thermal diffusivity. The lines are simply to guide the eye.

(Uncertainty in thermal conductivity is estimated to be $\leq 0.0014 \mathrm{Cal} / \mathrm{s} \cdot \mathrm{cm} \cdot \mathrm{K}$ ) 


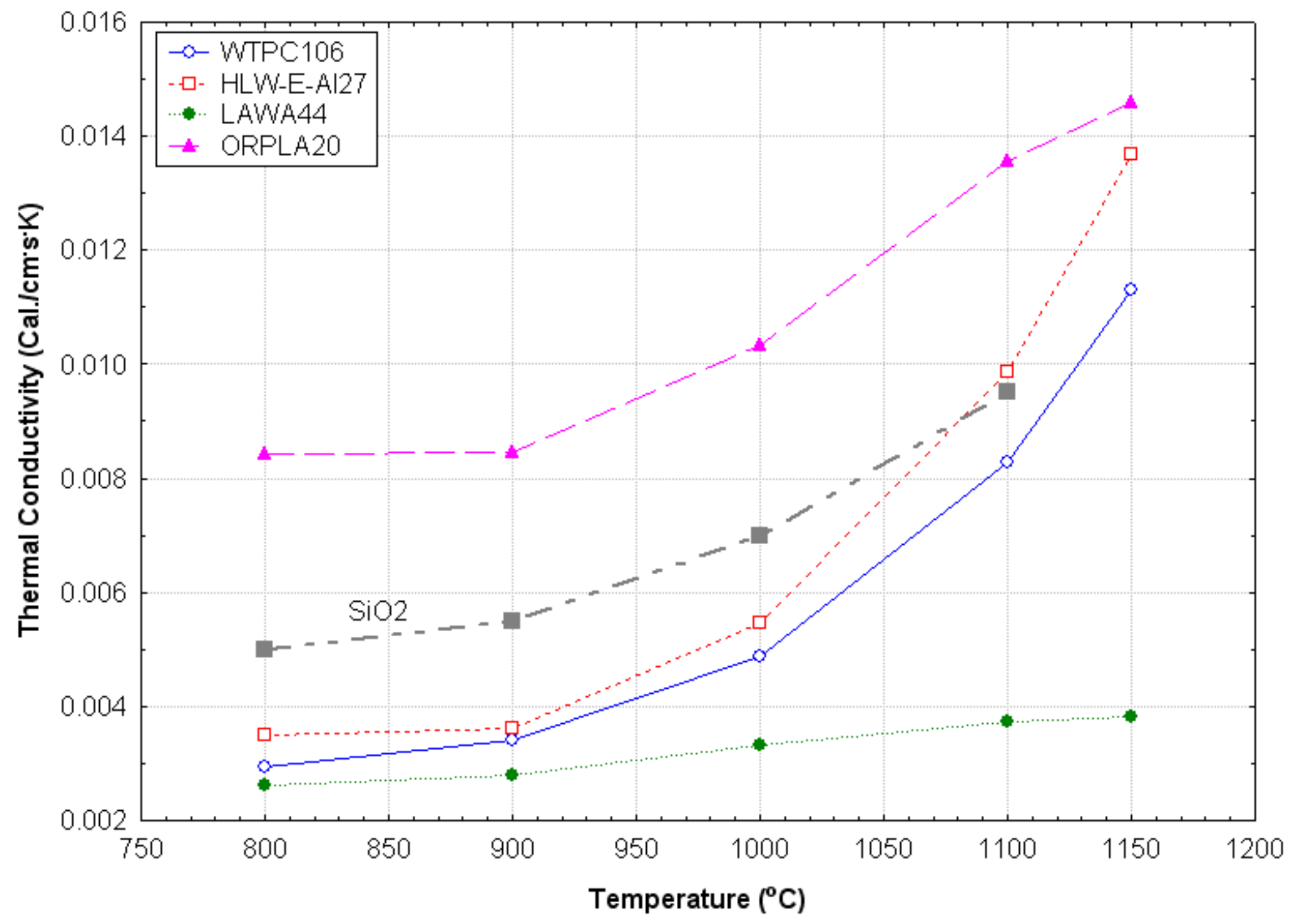

Figure 4.8. Thermal conductivity of four simulated waste melts in comparison to data for $\mathrm{SiO}_{2}$ glass.

The lines are simply to guide the eye.

(Uncertainty in thermal conductivity is estimated to be $\leq 0.0014 \mathrm{Cal} / \mathrm{s} \cdot \mathrm{cm} \cdot \mathrm{K}$ ) 